UNIVERSIDADE DE SÃO PAULO

FACULDADE DE FILOSOFIA, LETRAS E CIÊNCIAS HUMANAS

DEPARTAMENTO DE LINGUÍSTICA

GUILHERME WEFFORT RODOLFO

Música Predicadora de Sentidos:

análise fílmico/musical baseada na Semiótica Tensiva 


\section{GUILHERME WEFFORT RODOLFO guilhermewr@usp.br}

Música Predicadora de Sentidos: análise fílmico/musical baseada na Semiótica Tensiva

Tese apresentada ao Programa de Pós-graduação em Semiótica e Linguística Geral da Faculdade de Filosofia, Letras e Ciências Humanas da Universidade de São Paulo, para a obtenção do título de Doutor em Letras.

Área de concentração: Semiótica e Linguística Geral

Orientador: Prof. Dr. Waldir Beividas

Eu, Profesor Dr. Waldir Beividas, orientador do doutorado de Guilherme Weffort Rodolfo, estou de acordo com as alterações efetuadas nesse exemplar de tese com o objetivo de corrigir os pontos indicados pela banca de defesa na data de 29 de agosto de 2017.

Dia 25 de setembro de 2017.

Prof. Dr. Waldir Beividas

\section{São Paulo}

- versão corrigida - 
Autorizo a reprodução e divulgação total ou parcial deste trabalho, por qualquer meio convencional ou eletrônico, para fins de estudo e pesquisa, desde que citada a fonte.

Catalogação na Publicação

Serviço de Biblioteca e Documentação

Faculdade de Filosofia, Letras e Ciências Humanas da Universidade de São Paulo

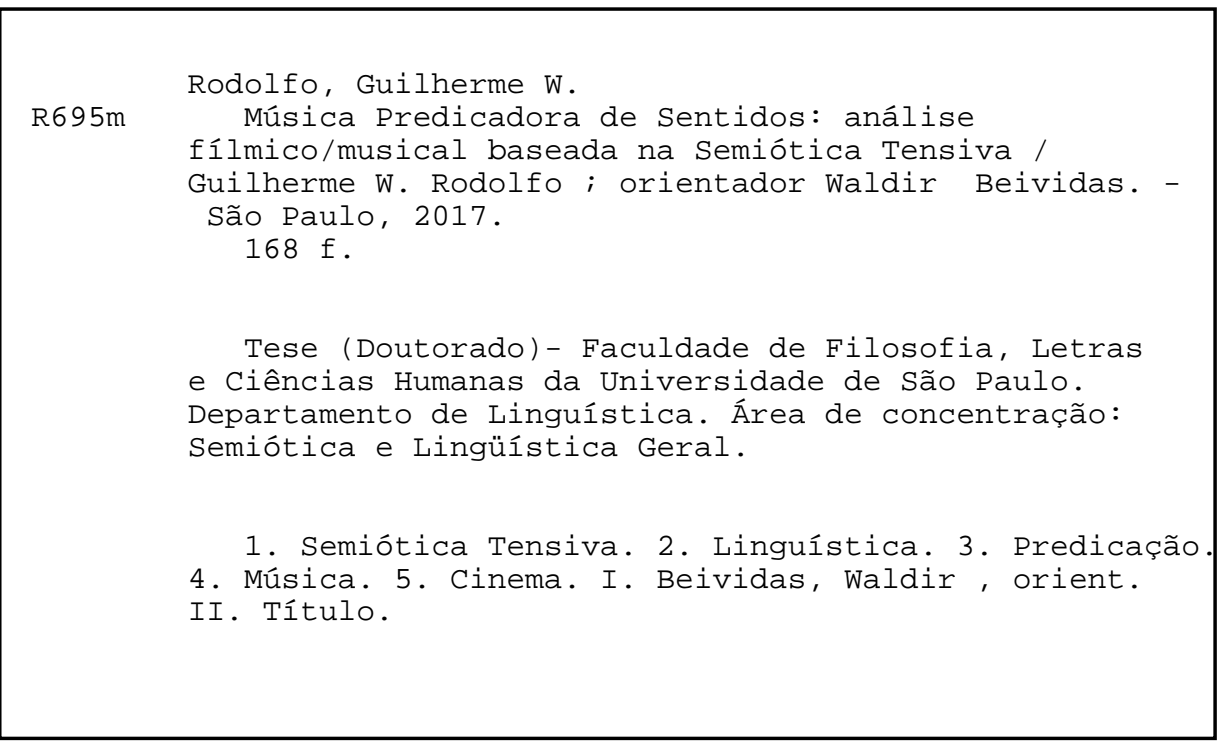


Nome: RODOLFO, Guilherme W.

Título: Música Predicadora de Sentidos: análise fílmico/musical baseada na Semiótica Tensiva.

Tese apresentada ao Programa de Pós-graduação em Semiótica e Linguística Geral da Faculdade de Filosofia, Letras e Ciências Humanas da Universidade de São Paulo, para a obtenção do título de Doutor em Letras.

Área de concentração: Semiótica e Linguística Geral

Aprovado em : 29 / 08 / 2017

\section{Banca examinadora:}

Prof. Dr.: Waldir Beividas

Instituição: USP - FFLCH - Dep. de Linguística

Prof. Dr.: Ivã Carlos Lopes

Instituição: USP - FFLCH - Dep. de Linguística

Julgamento:

Aprovado

Assinatura:

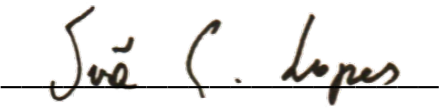

Prof. Dr.: Edson Roberto Leite

Instituição: USP - Inter Unidades - Estética e História da Arte

Julgamento: _Aprovado Assinatura:

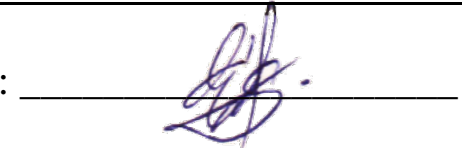

Prof. Dr.: Victor Aquino Gomes Correa

Instituição: USP - Eca - Dep. de Relações Públicas

Julgamento: __ Aprovado

Assinatura:

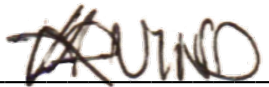

Prof. Dr.: Artur Matuk

Instituição: USP - Eca - Dep. de Relações Públicas

Julgamento:

Aprovado Assinatura:

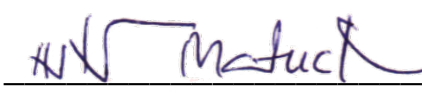


Aos professores, colegas e familiares que acreditaram e incentivaram essa jornada dedicada ao conhecimento externo e interno do ser. 
Agradecimentos:

A inexistência de análises sobre as composições musicais ligadas ao cinema motivou meus estudos sobre as narrativas e, consequentemente, sobre o discurso fílmico/musical. Assim, em 2013 fui aceito pelo Departamento de Semiótica e Linguística Geral da FFLCH para compor, orientado pelo Professor Waldir Beividas, um percurso de aprofundamento na Semiótica de linha francesa até a conclusão do trabalho aqui apresentado. A partir do aceite, cada gesto teve valor na construção das ideias e conceitos que carrego hoje. Dessa forma, quero dizer que o sentimento de gratidão que pretendo descrever dificilmente será compreendido, em sua totalidade, através das letras e sentenças aqui gravadas. Trata-se de uma concessão da memória que, se bem ajustada, permitirá descrever fatos: aparentemente nada mais que fatos. Mas peço, no entanto, que façam a leitura desse breve texto com olhos de bons músicos, desses que sabem fazer soar a música que existe “atrás” da partitura, a música que está entre as linhas e pontos da grafia, aquilo que não foi dito e, por ironia, somente escrito.

Dessa forma, agradeço a todos os amigos, colegas e professores, que conviveram, ajudaram e se preocuparam, ou seja, todos os felizes contatos que tive. São estes que me impulsionaram até o termino desse percurso. Devo agradecimentos aos meus familiares que acreditaram no projeto e também à minha Silvia que, além do incentivo, me fortaleceu todos os dias em que estive envolvido de corpo e alma na pesquisa e na escrita.

Devo ainda agradecer os atos de coragem, paciência e fé: a coragem de meu orientador, Professor Waldir Beividas, em concordar com aquelas ideias dispostas no pré-projeto e que, posteriormente, e sob sua batuta, encontraram harmonia para a conclusão desse trabalho; a paciência do Professor Ivã Carlos Lopes que, sem barreiras, esteve sempre atento aos pequenos atos de transformação daquelas mesmas ideias; e a fé de todos os professores e colegas que, mesmo vendo os passos de um suposto progresso, sempre acreditaram na conclusão.

Abro o espaço e o tempo para agradecer aos professores da ECA, Escola de Comunicações e Artes da USP, do PGEHA, Programa de Pós-Graduação Interunidades em Estética e História da Arte da USP e do IA-UNESP, Instituto de Arte da UNESP que acompanham meus passos acadêmicos desde o retorno à pós-graduação, posto o período envolvido em áreas da comunicação publicitária e cinema.

Por fim, os agradecimentos referentes ao percurso do doutoramento, como esta área parece tentar reter, expandiram suas impressões temporais, tornando-se, ao todo, pensamentos constantes da vida acadêmica. Agradeço, além da bolsa, a acolhida, o carinho e as amizades que guardarei para sempre e retribuirei em forma de trabalho e fraternidade. 
La musique souvent me prend comme une mer! Vers ma pâle étoile,

Sous un plafond de brume ou dans un vaste éther, J e mets à la voile;

La Musique (BAUDELAIRE, 2015: 242) 
Resumo:

RODOLFO, Guilherme W. Música Predicadora de Sentidos: análise fílmico/musical baseada na Semiótica Tensiva, 2017. 168 f. Tese (Doutorado) - Faculdade de Filosofia, Letras e Ciências Humanas, Universidade de São Paulo, 2017.

Músicas compostas para cinema são regularmente apontadas como motivadoras de amplificações sensíveis de uma cena. Podemos perceber essa alteração gerada pela música do filme, mas dificilmente encontraremos argumentos que comprovem, ou tracem uma análise mais precisa e que fique longe de especulações. Através da Semiótica Tensiva, principalmente a desenvolvida por Claude Zilberberg, podemos considerar a existência de uma música predicadora e sentidos, capaz de mostrar a alteração do núcleo de significações de um enunciado fílmico/musical. A predicação musical é utilizada como base do argumento que mostra a dinâmica de transmissão de afetos reconhecida entre enunciador e enunciatário: uma construção retórica praticada pelo meio de comunicação cinema. A análise do exemplo, a cena do Batismo, do filme O Poderoso Chefão, de 1972 e dirigida por Francis Ford Coppola, exigiu a criação de um método de análise que se configurou em níveis, objetivando o entendimento das cumulações e cadências promovidas pela predicação musical, e assim, a visão das figuras de retórica existentes no meio. A análise mostra o processo de composição e edição da cena e seu efeito de contato com o expectador, que apreende os códigos culturalmente estabelecidos e apresentados em ações relacionais na narrativa. A música é predicadora de sentidos e é utilizada como construtora dos elementos persuasivos do cinema.

Palavras-chave: Semiótica Tensiva, Linguística, Predicação, Música, Cinema. 
Abstract:

RODOLFO, Guilherme W. Music predicater of senses: a film/music analysis based in Tensive Semiotics, 2017. 168 f. Tese (Doutorado) - Faculdade de Filosofia, Letras e Ciências Humanas, Universidade de São Paulo, 2017.

Music composed for films are regularly pointed out as motivators of amplification of the sensibility of a scene. We can observe this alteration in sense produced by the music of the film, but we hardly will find arguments to confirm it or draw a more precise analysis of it. Through the Tensive Semiotics, especially the one developed by Claude Zilberberg, we can consider a existence of a music that predicates de senses, that is capable of showing the alteration in the nucleus of the sense of the filmic/musical utterance. The musical predication is used as a base of an argument that shows the dynamics of transmission of affects, recognized between enunciator and enunciate: a rhetorical construction practiced by the means of communication cinema. The analysis of the example, The Baptism scene, from the film The Godfather,1972, directed by Francis Ford Coppola, required a creation of an analysis method that was configured in levels, aiming the understanding of cumulations and cadences promoted by the musical predication, and thus, the view of rhetorical figures in the middle. The analysis shows the process of the composition and editing of the scene and its contact effect with the viewer, who assimilate the culturally established codes and presented in relational actions in the narrative. The music is predicator of senses and is used as a constructor of persuasive elements of the cinema.

Keywords: Tensive Semiotics, Linguistics, Predication, Music, Cinema. 


\section{Sumário}

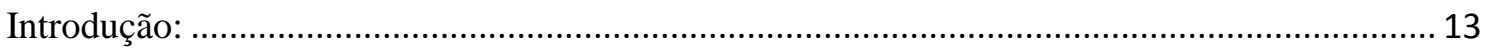

Capítulo 1: Considerações sobre a Semiótica Tensiva................................................................. 17

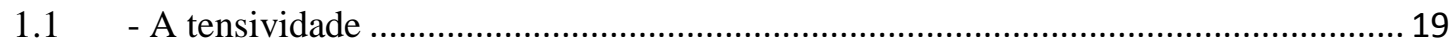

1.2 - Um conjunto de relações estruturais ........................................................................ 22

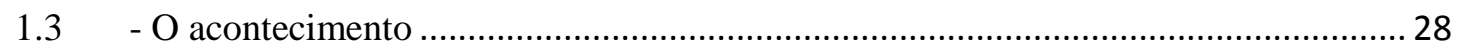

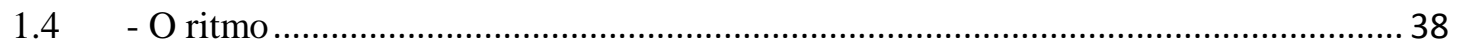

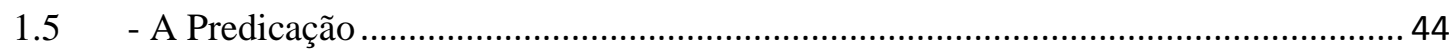

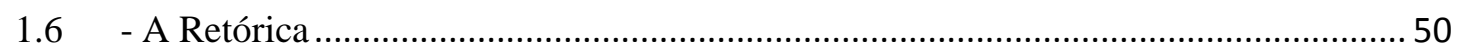

Capítulo 2: A escuta e a composição musical para cinema......................................................... 54

2.1 - Apontamentos históricos sobre a composição para cinema ............................................ 56

2.1.1 - Como nasceu "mudo" ............................................................................................ 56

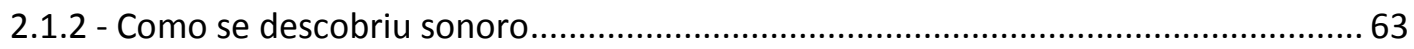

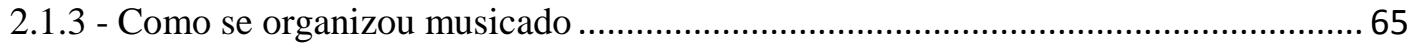

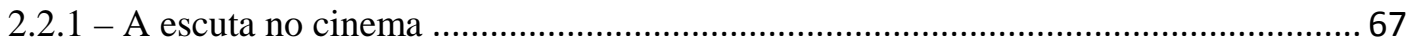

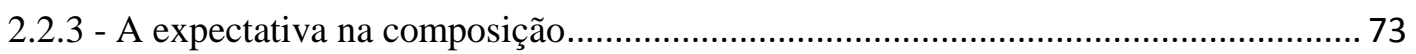

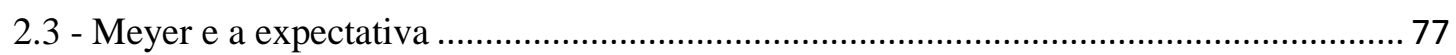

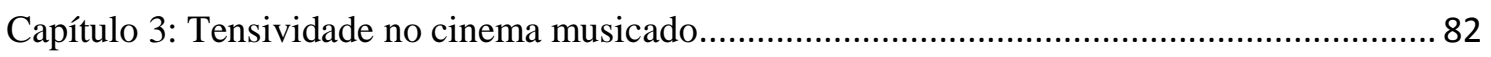

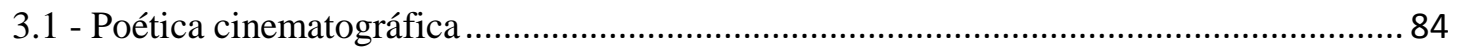

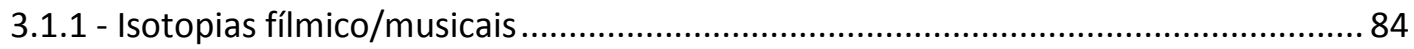

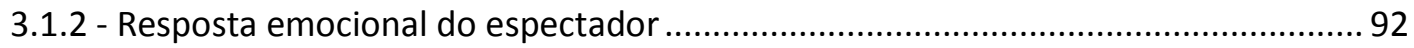

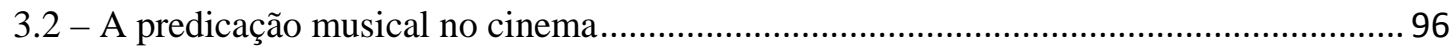

3.3 - A argumentação da música no cinema ..................................................................... 100

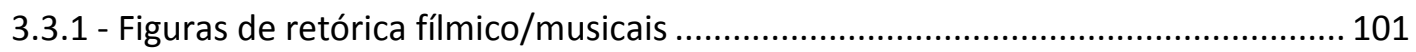

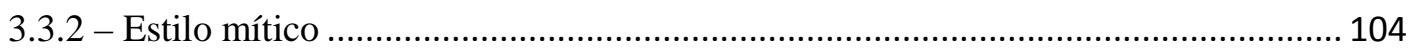

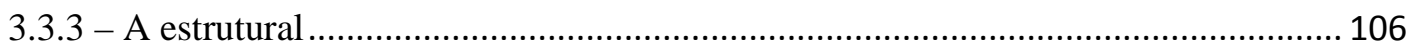

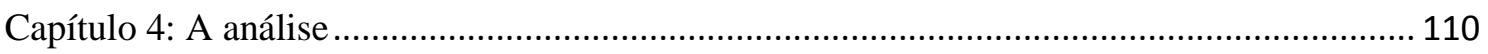

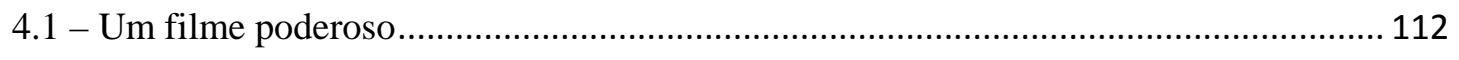

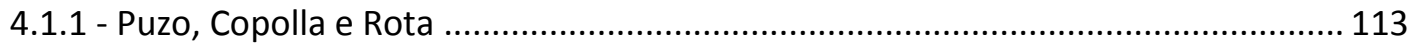

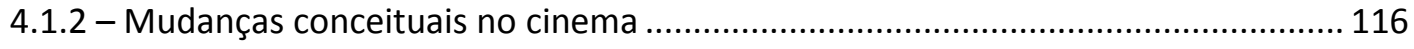

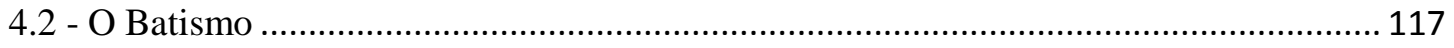

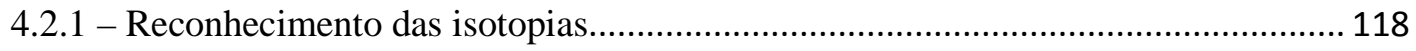

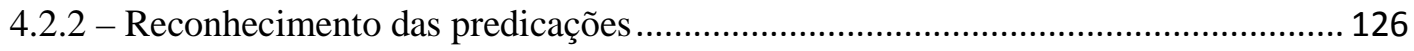

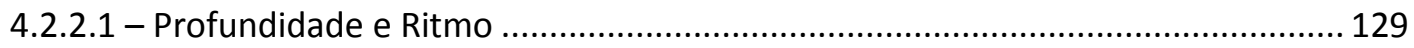


4.3 - A Tensividade do Batismo ......................................................................................... 140

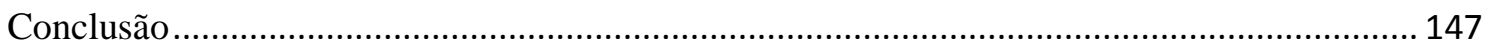

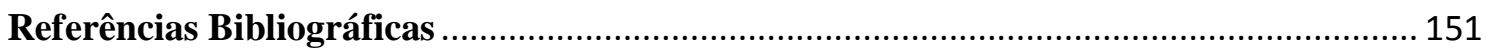

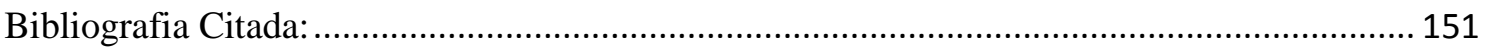

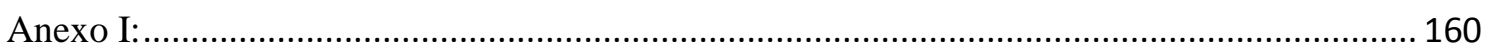

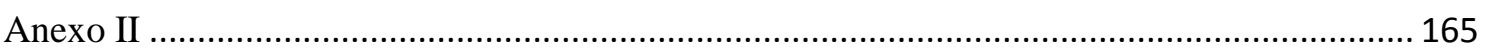

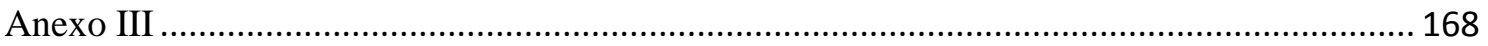




\section{Ilustrações:}

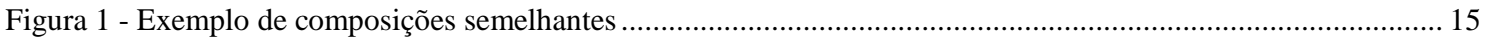

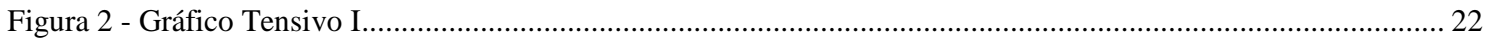

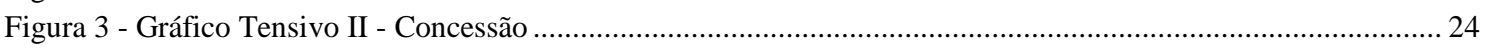

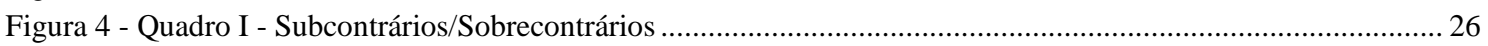

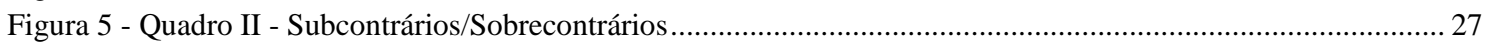

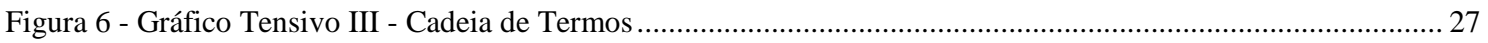

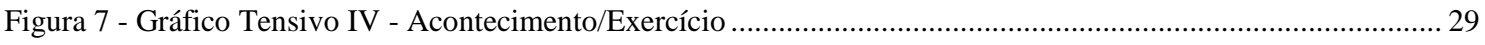

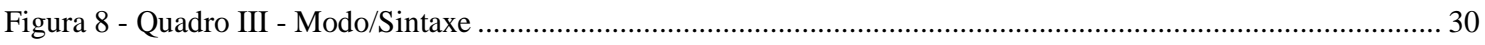

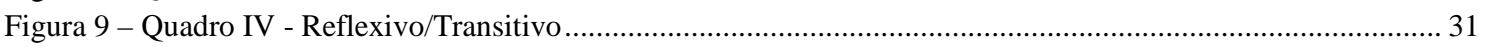

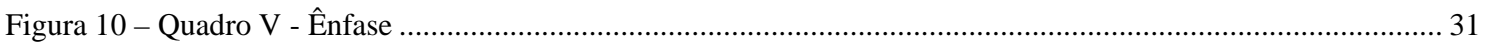

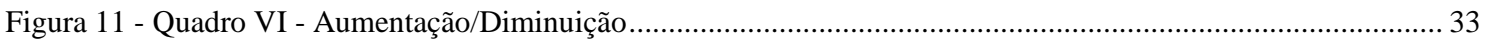

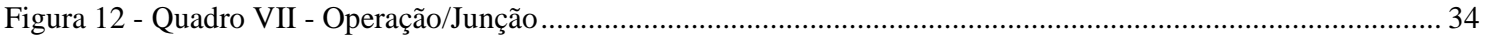

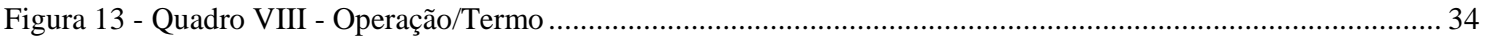

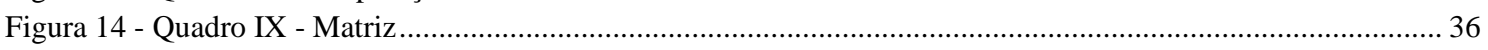

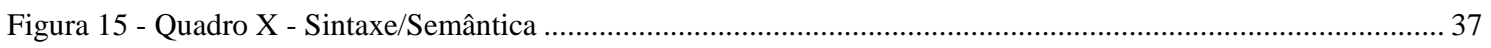

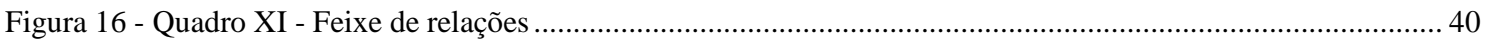

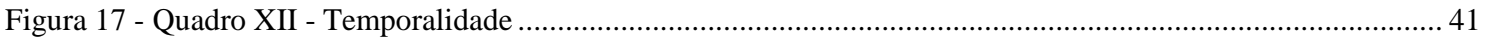

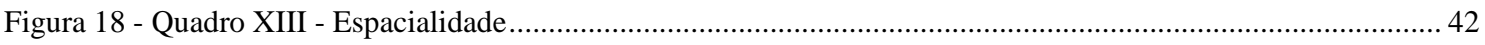

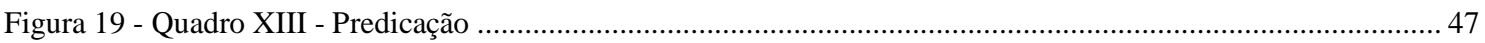

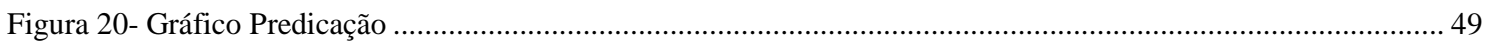

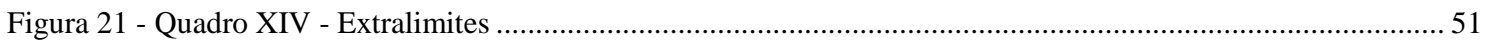

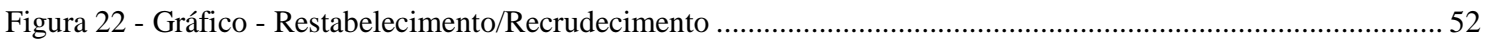

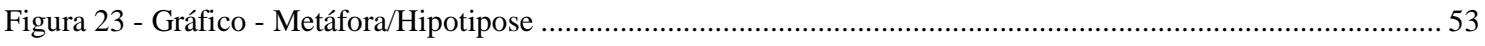

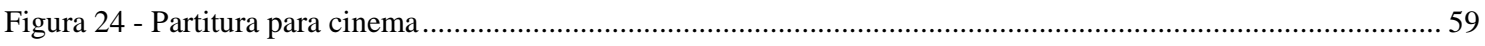

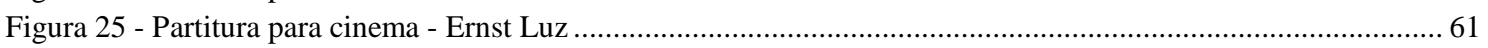

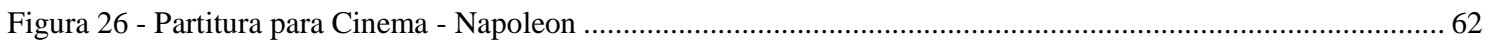

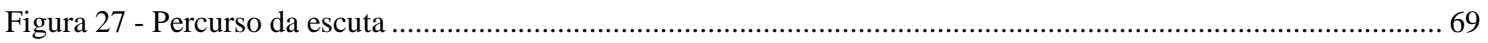

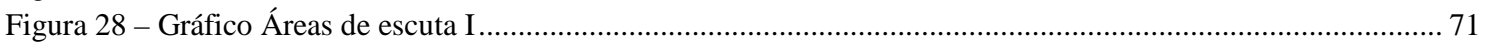

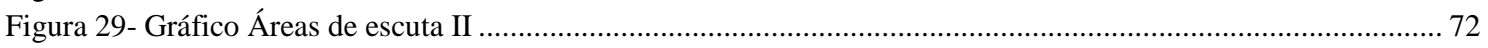

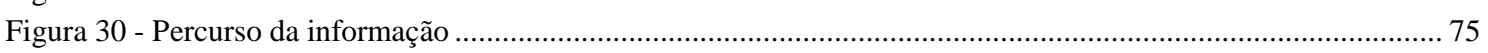

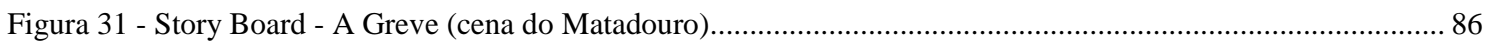

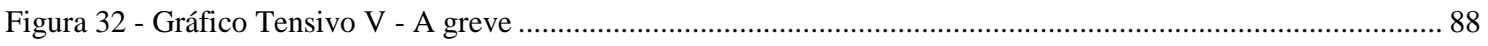

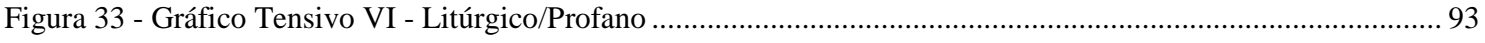

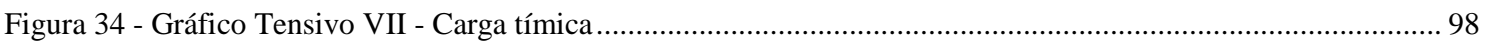

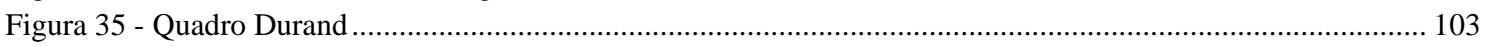

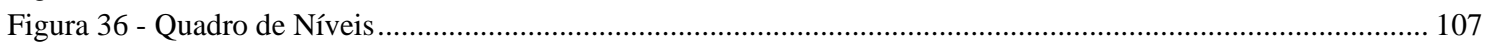

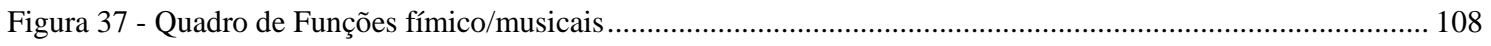

Figura 38 - Gráfico de Tempo, tema, volume e cortes ..................................................................................... 120

Figura 39 - Gráfico Tensivo VIII - Dissonância/Consonância .............................................................................. 121

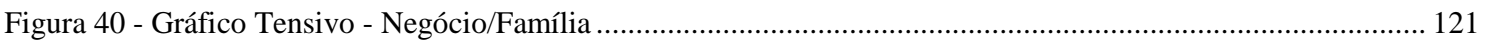

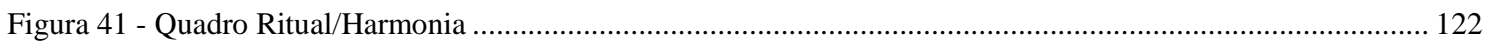

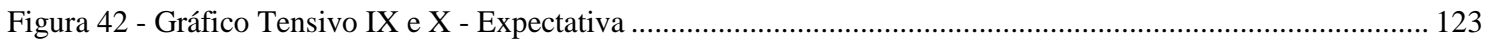

Figura 43 - Implicação/Concessão/Implicação................................................................................................ 124

Figura 44 - Gráfico Tensivo XI - Cadeia de Termos de Volumes....................................................................... 125

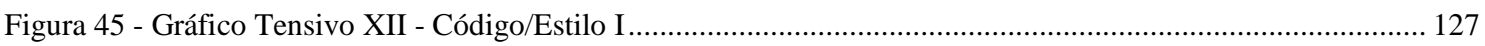

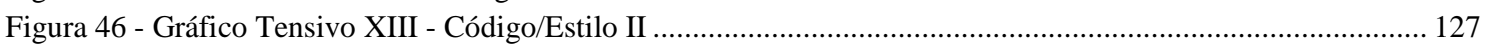

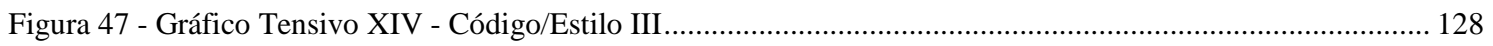

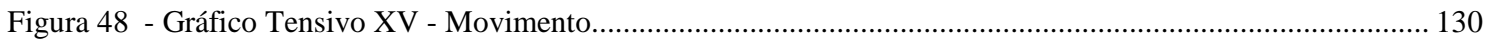

Figura 49 - Gráfico Tensivo XVI - Espaço Fórico .......................................................................................... 131

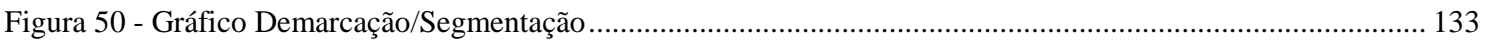

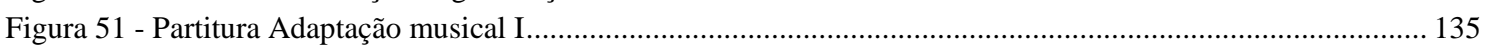

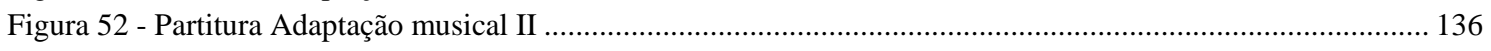

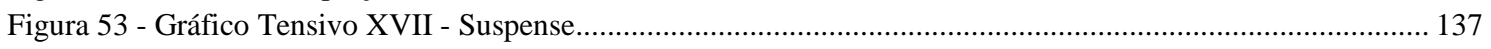

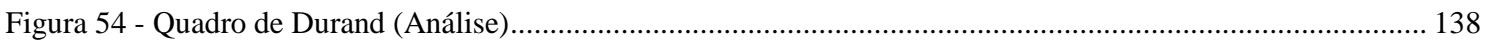






\section{Introdução:}

A música em produções fílmicas, tanto no cinema atual como nos diversos meios audiovisuais, compõe um importante argumento sensível e complementar do que apreendemos. Imagens em relacionamento com a música formaram as primeiras possibilidades de alterações conceituais em narrativas cinematográficas. A fala viria bem depois dos textos escritos na cena, somente quando o sincronismo se tornasse uma evolução tecnológica estável. O verbo se tornou a regra do cinema, a ponto de ser chamado de "verbocêntrico" pelo poder argumentativo e persuasivo que desenvolveu. Com isso, os mercados conduziram a indústria do meio de comunicação de massa testando pesos e medidas para a música, até seu encontro harmonioso com as vozes e os ruídos das cenas. São muitas as formas, clichês e leitmotivs dessa harmonia, somados a inovações valorosas que tornam as estruturas de narrativas em veículos de fácil aderência entre públicos, mas de difícil análise para pesquisadores.

A proposta deste trabalho é estruturar uma análise capaz de descobrir os elementos persuasivos da música no cinema. A tarefa parte da Semiótica Tensiva, aquela desenvolvida por Claude Zilberberg, relacionando-a com a análise musical de Leonard B. Meyer. Nesse sentido, a expectativa se torna o elemento de maior atenção, levando o abstrato referencial da música ao posto de mensurável e de uma possível graduação. A explicação está nos relacionamentos entre períodos e na observação entre meios, capazes de demonstrar a mudança nos sentidos visuais implicados pela música. Dessa forma, a música é a causadora da mudança de afetos, ou de seus reforços, pelo processo que chamamos de predicação.

Apresentada pelo próprio Zilberberg como complemento para a análise do Percurso Gerativo do Sentido, desenvolvida por A. J. Greimas, a Semiótica Tensiva parece ter tomado rumo próprio, sendo capaz de utilizar seus próprios recursos ao desenvolver análises. Os percursos analisados pela Semiótica Tensiva procuram observar as relações existentes de extensidade e intensidade, apresentando constâncias e suas variações em um campo tensivo. A teoria vai adiante ao descrever certa atualização dos conceitos retóricos, pois uma vez que foi projetada para a análise de discursos, percorrerá invariavelmente o caminho da persuasão. A partir de diversos escritos de Zilberberg, o primeiro capítulo desse trabalho tenta descrever e compilar uma Semiótica Tensiva já em caráter estrutural, ou seja, o que o próprio autor indica como um quadro 
de hierarquias bem feitas (2012: 55). Na teoria, o campo de presença, promovido pelos eixos de intensidade e extensidade, demonstrará uma cadeia de termos em escala que, aplicados a cada caso, mostrarão especificidades em seus movimentos ascendentes e descendentes, de forma linear ou sincopada, representando as variações de acontecimentos e exercícios da narrativa. Sobre esta formação tensiva, os paradigmas de tempo e espaço darão as noções de ritmo e profundidade respectivamente, úteis na análise do objeto deste trabalho. A leitura sobre uma ação argumentativa justificará os objetivos da Semiótica Tensiva, elegendo a retórica como sistema de produção discursiva. Na sequência da exposição desse capítulo, interpomos as questões sobre a música como escuta e sua possibilidade de novas expectativas, apresentando o pensamento de Pierre Shaeffer e a teoria acusmática. A teoria de Leonard Meyer vem em seguida para expor uma análise musical baseada, entre outros, na teoria da informação, parte apresentada por Roman Jakobson e parte estimulada pelo desenvolvimento dos meios de comunicação de massa. Meyer vai adiante ao apontar, como Zilberberg, uma construção culturalmente estável e capaz de ser a causadora das propostas de composições musicais: o público aculturado e apto à absorção senciente de novos paroxismos: os acontecimentos de Zilberberg.

Passamos à fusão das ideias da Semiótica Tensiva aos conceitos musicais informacionais e de expectativa, aliados a uma breve colocação histórica da música no cinema. Esta história breve se tornou necessária ao destacar a preocupação do meio cinema com a música que, adiante, daria apoio em suas futuras mudanças estéticas. $\mathrm{O}$ elo entre Semiótica Tensiva e a teoria analítica de Meyer será abordada no terceiro capítulo juntamente com a proposta de análise fílmica de Christian Metz. Os sistemas e seus usos, os códigos e suas ocupações em um estilo são algumas ferramentas úteis que somarão graduações na Semiótica Tensiva até a ligação da música predicadora e sua execução retórica, existente nos meios de comunicação de massa, principalmente no cinema.

Dessa forma, consideramos provável o desenvolvimento da análise do percurso fílmico/musical, escolhendo a cena do Batismo, do filme O Poderoso Chefão, de 1972, dirigido por Francis Ford Coppola e adaptado do romance homônimo escrito por Mario Puzo. A controversa direção de Coppola causou incertezas ao estúdio Paramount, mas deixou audaciosos efeitos na história do cinema: a cena do Batismo é uma delas. Entre as polêmicas da produção estava a escolha do também controverso compositor italiano 
Nino Rota. Renomado por suas composições, dentro e fora do cinema, Rota opta por adaptar músicas já compostas e utilizadas em filmes, escolhendo uma rápida peça de sua própria autoria, mas já utilizada no filme Fortunella, de 1958 e dirigido por Eduardo de Filippo, para ser o tema principal de O Poderoso Chefão.

Figura 1 - Exemplo de composições semelhantes

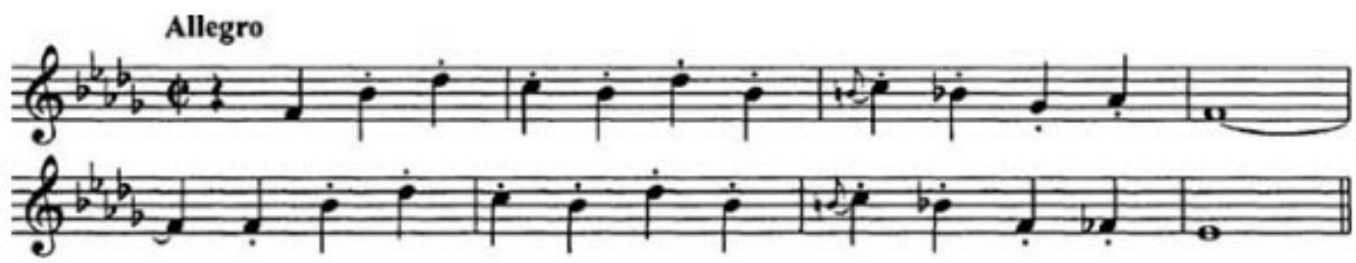

Tema de Fortunella, de 1958, escrito por Eduardo de Felippo e Federico Felline, dirigido por Eduardo de Felippo.
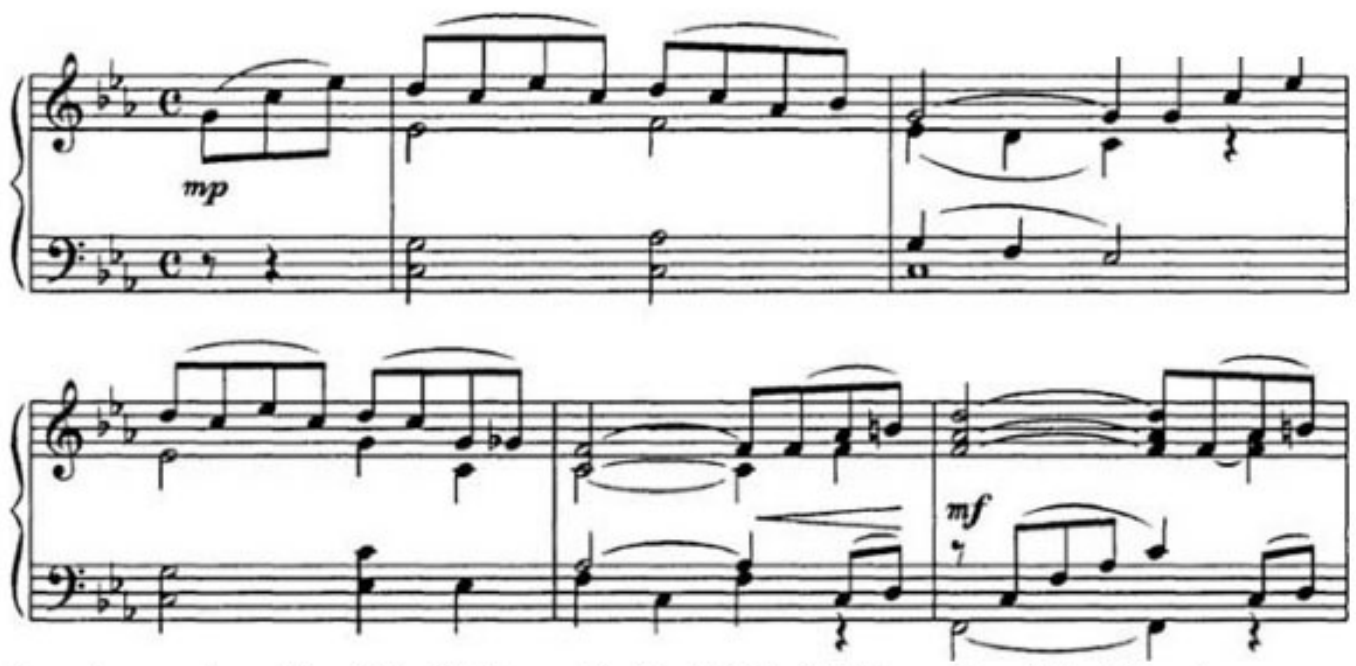

Tema de amor (Love Theme) de O Poderoso Chefão, de 1972, dirigido por Francis Ford Coppola.

SCIANNAMEO, Franco. Nino Rota's The Godfather trilogy: a film score guide. Maryland: Scarecrow, 2010. (livro eletrônico Kindle) - 38\% - posição 1525.

A música da cena do Batismo também é uma adaptação, muito criativa, mas adaptada de peças de Bach: a Passacaglia BWV 582 e o Prelúdio e Fuga em Ré Maior BWV 532. Ao todo compõem três temas musicais em sequência ${ }^{1}$ descrevendo significados extras à cena filmada. Rota não parece se importar com os "re-usos" de suas próprias músicas, afirmando estar preocupado com o resultado sensível que a música constrói.

\footnotetext{
${ }^{1}$ Anexo II
} 
Entendemos como necessária a explicação de alguns termos ou eventos que podem causar dúvidas durante a leitura. O termo música, além da noção geral que essa significação propõe, representa a questão de sua posição com os demais sons do filme. O que chamamos de música é, além do objeto central desse trabalho, a composição musical editada no filme, com seus volumes, orquestrações ou arranjos específicos que, a nosso ver, terão sua força argumentativa diante das imagens em movimento. O filme é o que restou além da música, ou seja, todo e qualquer ruído, falas, imagens e locuções. O filme é o que conhecemos como tal, com exceção da composição.

Outra questão que merece esclarecimento preliminar é sobre o não uso de alguns reconhecidos autores do campo da semiótica musical. Nomes como Nicolas Ruwet, Jean-Jacques Nattiez e Jean Molino serviram como formadores de parte do conceito do trabalho, mas não são citados por entendermos a distância referencial com a Semiótica Tensiva. O mesmo ocorre quando escolhemos a teoria analítica musical de Leonard Meyer postulando uma produção musical sobre a retórica e não apontamos os autores que descrevem a teoria das tópicas musicais, posterior ao trabalho de Meyer. O motivo também é ligado à necessidade de formar um paralelo com a Semiótica Tensiva que, aparentemente, só a teoria de Meyer comportaria. Ainda não existem aproximações entre a Semiótica Tensiva de Zilberberg e a música, caminho diferente encontrado na semiótica greimasiana, deixando-nos como avaliadores preliminares de um vasto campo que este trabalho tenta aproximar.

A análise proposta pela Semiótica Tensiva, executada na cena do Batismo, revela acontecimentos importantes e úteis na apreciação do evento. As constantes quebras do contínuo da cena tornam-se marcadores essenciais, utilizados na quantificação tensiva. Revela-se, portanto, a confirmação do uso da retórica no meio, reforçado e autenticado pela posição da música predicadora de sentidos sobre as ações do filme. Assim, esperamos abrir um caminho para futuras análises sobre a estrutura da Semiótica Tensiva, assim como possíveis reflexões a partir desse novo estruturalismo aliado aos meios de comunicação de massa. 
Capítulo 1:

Considerações sobre a Semiótica Tensiva 


\section{1 - Considerações sobre a Semiótica Tensiva}

Originária da Teoria Semiótica greimasiana, a Semiótica Tensiva desenvolveu seu rumo próprio e, segundo seu principal autor, Claude Zilberberg, com o papel de complementar o método de Greimas. A teoria de Zilberberg observa um campo de presença, capaz de representar eventos e analisá-los, fazendo a leitura das tensões e relaxamentos dispostos sobre o inteligível e o sensível. Dessa forma, podemos analisar o sentido de textos por suas forias, expondo valores e relações, entre outros elementos, que mostrarão interdependência e certa estrutura formal dos objetos analisados. De fato, para que exista comunicação, portanto persuasiva, analisamos a eficiência discursiva, presente nos eventos, os acontecimentos diante do ser. Reconheceremos assim, um mecanismo de produção textual destinado ao observador e de possível análise por esta teoria.

Por se tratar da fundamentação analítica via Semiótica Tensiva, passaremos pela ação dos modos semióticos: de eficiência, de existência e de junção; capazes de compor o andamento do texto e dos conceitos de implicação e concessão, úteis ao analista da Semiótica Tensiva. Como veremos, a concessão é tratada como uma fase transitiva entre duas implicações, dando a sensação de ruptura no contínuo textual. Essas rupturas serão nossas possibilidades de análise dos períodos, ritmos e processos persuasivos do texto fílmico/musical. Cada evento é limitado por uma cadeia de termos, os subcontrários e os sobrecontrários. Dessa forma, no decorrer do percurso analisado, somado às interdependências dos elementos da estrutura, poderemos reconhecer os níveis morfológicos, sintáxicos e semânticos, ricos aos estudos da semiótica. A sintaxe e a semântica parecem manter um papel importante na Semiótica Tensiva, pois moldarão os conceitos de sobrevir diante de um pervir, ou ainda, o acontecimento e o exercício. Dessa forma, chegaremos à ótica de reconhecimento dos movimentos em cadeias de termos, e assim, a possibilidade de análise do ritmo.

Uma questão se eleva na Semiótica Tensiva que chama a atenção analítica deste trabalho, ainda mais se considerado o tema que nos propomos, trata-se da questão da predicação. A predicação é percebida quando um elemento da estrutura discursiva se 
sobrepõe a outro, reformulando sua aparição aos olhos do analista, mas, se bem observado, mantendo suas dependências relacionais. Observamos a ação de uma recção, comum nas ações frasais e seus elementos regidos por um regente, e da mesma forma, em textos transfrásticos. A predicação trará o argumento forte à outra questão ponderada pela Semiótica Tensiva que se espalhará no conteúdo de todo o trabalho: a retórica. Esta última verá a repetição e o empilhamento de elementos do discurso produzirem ideias culturalmente estáveis e ordenadoras de mitologias.

Dessa forma, faz-se presente a apresentação da Semiótica Tensiva, esta desenvolvida por Claude Zilberberg, assim como o desenvolvimento necessário para as futuras argumentações desse trabalho.

\section{1 - A tensividade}

Combinações diferentes de manifestação compartilham a mesma inteligibilidade. Zilberberg $^{2}$

Na formação da chamada semiótica de linha francesa, Algirdas Julien Greimas preocupou-se com a teoria do discurso com base estruturalista. Publica, em 1966, o livro Semântica Estrutural, onde desenvolve uma ciência da significação obrigatoriamente voltada à linguística saussuriana por apoiar-se nas relações geradoras de sentidos, ao contrário do sentido advindo das unidades mínimas, proposto no início dos estudos sobre a significação do mesmo Ferdinand de Saussure. Com isso, propõe a não existência de um valor absoluto da significação, mas um sentido produzido por relações: a significação é “considerada tanto como eixo semântico quanto em sua articulação em sema” (1976: 36), apontava o eixo da estrutura remanejado dos escritos de Hjelmslev. Mais inclinado ao estudo do discurso do que da língua, Hjelmslev parece executar a ação contrária dos fonologistas de sua época que descartavam o sentido na busca do signo constituído, a exemplo da operação de comutação. Com isso, Hjelmslev

\footnotetext{
${ }^{2}$ Des combinaisons diferentes par leur manifestation relèvent de la même intelligibilité.(ZILBERBERG, 2012: 34)
} 
trabalha a exclusão do plano da expressão compreendendo apenas o sentido, ou seja, o plano do conteúdo. Isso promoveu o desenvolvimento de uma análise interessada na melhor verificação das narrativas, lançando a ideia de sua eficiência pela ótica do campo inteligível. Greimas descreve o que passaria a ser a semiótica que conhecemos, privilegiando não apenas o inteligível, mas também deixando o sensível, o plano da expressão, pouco articulado. O plano da expressão irá reaparecer como interesse da ciência semiótica quando da necessidade de analisar o sentido de outros tipos de textos: os textos poéticos, os textos musicais, os fílmicos, fotografias, etc. Só com a inclusão do sensível é que seria possível a compreensão do universo passional contidos em tais textos.

Sem se distanciar da proposta de Hjelmslev e apoiando-se na ideia de funtivos como relacionais entre objetos, o desenvolvimento da semiótica passou à observação do nível profundo greimasiano com o projeto de categorizá-lo por meio das relações existentes em uma cadeia de estados fóricos. Esta seria a indicação de Claude Zilberberg que conjugou a articulação entre tensão e relaxamento com a oposição de ações entre extenso e intenso. A “diretividade da foria” (2006: 132) consegue demonstrar, como um teorema, que um traço saliente é visto como um elemento intenso, uma vez que é "implosivo”, compacto, e localizado; já o não traço, a "passância”, é visto como elemento extenso, sendo "explosiva”, não compacta e não localizada. No dispositivo, aponta a possibilidade de uma observação da temporalidade figural articulada como intensa: gerando temporalidades de expectativa e de espera; ou articulada como extensa: gerando temporalidades “originantes” capazes de reparar perdas (ZILBERBERG, 2006: 132-3). Indica ainda uma espacialidade figural, essa também articulada em intensa e extensa geradoras de localizações concentradas e difusas respectivamente. Com a intensidade representando o sensível e a extensidade o inteligível, declara um lugar comum relacionando-os e chamando-os de espaço tensivo, capaz de receber as grandezas aparentes no campo de presença. As grandezas representarão o objeto semiótico que agora aparece como um evento, e é esse evento que a Semiótica Tensiva irá analisar, em um período de tempo escolhido para sua definição. Com isso, Zilberberg espera que o sistema da semiótica tensiva esclareça, em análises, como a foria produz um tempo/espaço figural (ibidem), e com isso, o sentido do texto. 
Por tratar das condições escolhidas por esta pesquisa e por conter uma grande quantidade de explicações epistemológicas sobre a Semiótica Tensiva, escolhemos os estudos de Zilberberg, em algumas de suas publicações, para o desenvolvimento do assunto. Principalmente apoiados em La structure tensive, de 2012, recorremos à formação da ideia tensiva, sua organização e seu desenvolvimento, organizando-a como teoria ligada ao pensamento estrutural. De fato, parece-nos, a própria condição em que observa os acontecimentos, seus valores, classes, relações, dependências e interdependências, indicam uma ordem estrutural escolhida por Zilberberg, que passamos ao desdobramento.

Podemos marcar uma posição inicial para o conceito da semiótica tensiva resgatando uma das ideias “fundamentais” da linguística. Em análise, o posicionamento do indivíduo nos escritos de Saussure, sendo este nutrido de vontade e inteligência, realizadoras de códigos comuns e de um mecanismo psicofísico reprodutor das combinações códicas (SAUSSURE, 2012: 45), indicam a construção do discurso como material persuasivo necessário à comunicação. Zilberberg apoia-se na questão da persuasão e, resgatando o livro III da Retórica de Aristóteles, demostra esta persuasão como elemento necessário para uma eficácia discursiva (ZILBERBERG, 2012: 32). Teremos então, retirados de Aristóteles quatro características: (i) o entimema, gerador de certa rapidez na recepção do discurso; (ii) o susto, construído por metáforas: “é o momento em que a Grécia lançou um grito"; indica um colocar uma coisa diante dos olhos, configurando um susto; (iii) este “diante dos olhos” pressupõe alguma foria por entender uma ação contínua; e (iv) a concessividade, por extrair a metáfora do tema, mas esta não evidente. Essas quatro características encontradas na terceira Retórica indicam as quatro propriedades tensivas: a rapidez, o susto, a foria e a concessividade. Dentro desse tema, irá localizar os espaços e velocidades de eventos, os acontecimentos observáveis pela união das posições graduais da intensidade e da extensidade.

A Semiótica Tensiva passa a compreender um espaço tensivo, ou seja, onde a pluralidade percebida pode ser analisada em seus dois eixos observados em conjunto: intensidade como soma dos estados da alma e a extensidade como soma dos estados de coisas, tudo em um mesmo espaço. Neste espaço, observa-se o conjunto e as relações dos objetos semióticos escolhidos, somados a "graus” imaginários e arbitrados pelo analista. Muito importante para a análise, as grandezas aparecem no mesmo espaço 
tensivo, indicando a linearidade da expressão e a amplitude do conteúdo posicionado pela convergência entre os planos.

Figura 2 - Gráfico Tensivo I

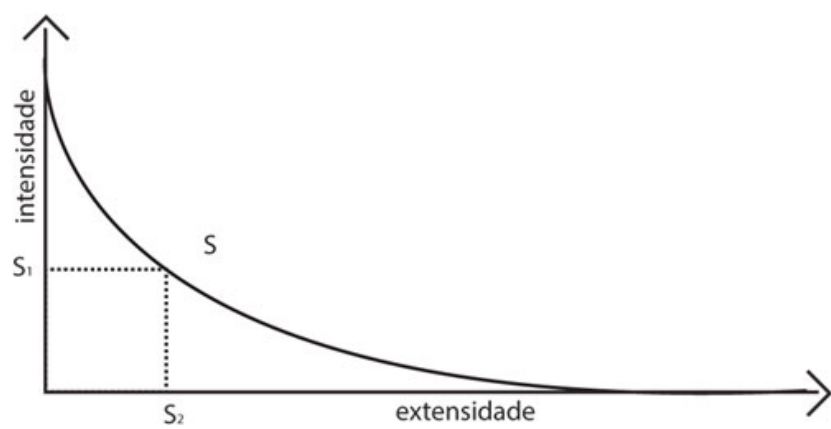

Para que se crie a convergência, executa-se a colocação escalar nos eixos da intensidade e da extensidade: a intensidade representa a ordem subjetal por apresentar os desvios observados em uma norma como conteúdos mensuráveis. Isto é, a indicação de um elemento na intensidade não se apresenta por /mais/: modalidade objetal, mas por /demasiado/: modalidade subjetal. Na extensidade, por não representar os traços de desvio, indica a densidade do campo de presença: sendo as grandezas pouco numerosas, a extensidade será concentrada, se muito numerosa, será difusa. Assim, o espaço tensivo representa a leitura de uma força com a qualidade dessa mesma força diante de um evento. A análise é possível graças a leitura da intersecção dos dois eixos, gerando uma relação que localiza o objeto semiótico, assim como a continuidade dessa relação, chamados por Zilberberg como complexidade e homogeneidade respectivamente. A intersecção também garante a virtualização da ação, uma vez que o evento acontece em uma constância e sua não-realização seria, para o sujeito, como um objetivo a realizar. A constância mostrará não só o valor, ponto de intersecção da intensidade com a extensidade, mas a variação de afeto e sua localização no espaço tensivo. Como na leitura de Aristóteles, a leitura dos acentos intensivos, reconhecidos na intersecção, indicará um mecanismo de produção, muito útil ao analista e esclarecedor de uma persuasão.

\section{2 - Um conjunto de relações estruturais}

No desenvolvimento do método de análise, Zilberberg apresenta o espaço considerado pela intersecção, o espaço tensivo, como o local da ocorrência do evento a 
ser analisado. Esse local define-se como campo de presença e mostra os acontecimentos interpretados pelas grandezas instituídas pelo evento. É no campo de presença que as relações aparecerão indicadas pelos modos semióticos.

São três os modos semióticos descritos pela teoria: (i) o modo de eficiência, que mostra um estilo de apresentação de grandezas; (ii) o modo de existência, que auxilia o modo de eficiência mostrando a relação do sujeito com o objeto; (iii) o modo de junção, que apresenta uma atividade sobreposta de um fato sobre o contínuo. Estes três modos semióticos serão como indicações do andamento dos textos, como os nomes indicadores de andamentos em partituras musicais: adágio, alegro, largo, etc., que ajudam na execução do intérprete dando a este as referências conceituais do texto musical (ZILBERBERG, 2012: 37-42).

Observador dos súbitos eventos em um contínuo, os sobrevires em seus devires, o modo de eficiência se refere a maneiras pelas quais as grandezas se instalam no campo de presença. As grandezas instaladas darão a visão das alternâncias dos sobrevires que adentram o campo de presença do sujeito. Ou seja, este ato significante será o promotor de um estilo por conter sobrevires e devires reconhecíveis e, assim, delineadores do afeto para a intensidade e do inteligível para a extensidade. No que concerne à observação do sujeito, a tensão que se formará terá lugar no modo de existência, uma vez que prevê a tensão entre um foco e uma apreensão ${ }^{3}$ dos acontecimentos. O foco refere-se ao "chegar em algum lugar”, ou ainda, o pervir que é visto como a "espera” diante do contínuo. A apreensão refere-se ao sobrevir, passivo, de um "ser captado”. Zilberberg indica um paradigma processual nessa tensão: “O foco é solidário da 'atividade’ na mesma medida em que a apreensão está em consonância com o “processus”” (2012: 39). O período escolhido de análise dispõe de um "ter em vista um resultado" referenciado pela espera, isto é: o foco; e, de um "ser captado", passivo, da apreensão. Aqui, a espera e a passividade serão reagrupadas pelo modo de eficiência compondo os espaços entre rupturas do contínuo. Resta-nos a conciliação do modo de junção, o sobrevir adicional do evento demonstrado pela "grandeza instalada entre grandezas” (2012: 39) já estabelecidas no campo de presença. Essa grandeza, recém-promovida, pode aparecer de duas formas: ou ela concorda com as grandezas

\footnotetext{
${ }^{3}$ Nas palavras de Zilberberg: visée e saisie. 2012, p. 38.
} 
existentes, a que Zilberberg chama de “implicação", ou discorda, chamada de “concessão”.

Conceito central da Semiótica Tensiva, o acontecimento é a conclusão de uma transição entre implicações. Estas são observadas pela ocorrência restrita de “se...então....” dentro do campo de presença. Ou seja, uma grandeza que aparece tendo uma intensidade $I_{1}$ relacionada a uma extensidade $E_{1}$, sua intersecção é vista como uma grandeza que ocorre pela implicação: se $\mathrm{I}_{1}$, então $\mathrm{E}_{1}$. No mesmo período, existindo outra grandeza, gerada pelo mesmo sistema porém com $\mathrm{I}_{2}$ e $\mathrm{E}_{2}$, promoverá um evento com duas constantes que, por ocorrência de um acontecimento, teve uma transição em salto. Este "salto” é representado pela concessão de uma implicação para outra implicação: concede-se a ruptura entre constantes.

Figura 3 - Gráfico Tensivo II - Concessão

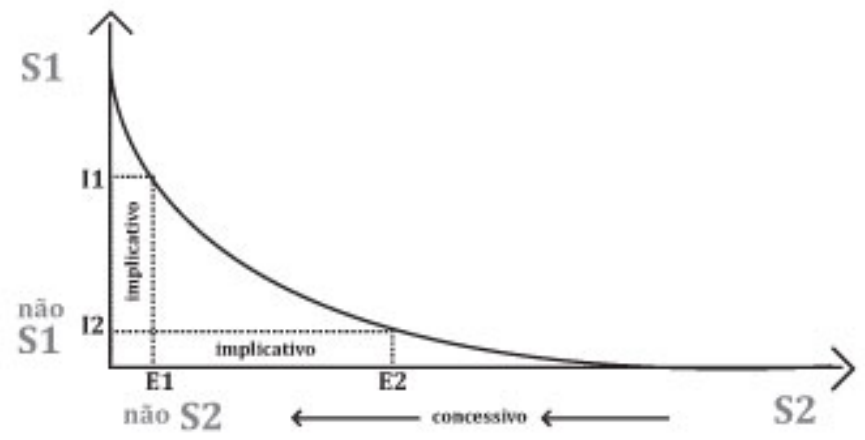

No exemplo, a ruptura é vista pelo movimento no eixo da extensidade marcado pela concessão. “A semiótica do acontecimento não é uma semiótica de oposições, é uma semiótica da interdependência, da solidariedade e da não conciliação que está associada a ela.” (ZILBERBERG, 2012: 28)

Reafirmando os caminhos argumentativos advindos da retórica de Aristóteles, Zilberberg indica a concessão como conceito inicial desta disciplina por desenvolver-se na argumentação. Aristóteles defende que o discurso age com uma meta utilitária, que elege seu conteúdo ignorando o que não é do interesse da persuasão ${ }^{4}$. A implicação se pareia ao entimema e ao silogismo, mas deve unir-se à concessão, que retira sua continuidade, com a finalidade de propor a introdução da argumentação na análise tensiva. Se esta argumentação não se apresenta, a Semiótica Tensiva só poderá analisar questões de caráter do "se isso...então aquilo", dentro de uma implicação não

\footnotetext{
${ }^{4}$ Aristóteles, 1996, p.93 - apud Zilberberg, 2002, p.138
} 
argumentativa. Com isso, propõe uma expansão das oposições, aparentemente estabilizadas na semiótica, para a criação de uma leitura de termos em linha: um sintagma de termos complexos (ZILBERBERG, 2011a: 77-81). A vantagem da introdução da concessão se apresenta desde sua definição, articulada como uma causalidade diante de uma não operação (ZILBERBERG, 2002: 139). Isto é, a possibilidade da leitura do “embora...” na distribuição dos termos, agora, expandidos.

Zilberberg desenvolve uma semiótica do intervalo para justificar a falta que o estruturalismo fez em não “conceber as propriedades da relação” em suas análises indicando o "termo" como prioritário (2002: 125). No pensamento saussuriano das oposições, dos contrários e repensada em contraditórios por Greimas, indica que nem todos os contrários são equivalentes por serem da ordem da decisão definitiva, ou da ordem das contrariedades mínimas (idem). Assim, aponta a necessidade de observar os termos como sobrecontrários, sendo tônicos e distantes, e, subcontrários, sendo átonos e próximos. As relações tônicas são, portanto, do plano do conteúdo, enquanto que as átonas são do plano da expressão, dessa forma, a passagem do plano da expressão para o plano do conteúdo descreve um percurso das relações átonas em direção as tônicas. Propõe então a construção da cadeia a partir das oposições primarias, partindo dessas o acréscimo de termos que demonstrem do início da irrupção ao seu término. Aponta assim, o continuum que fornece graus e limites, aparentes na substância do conteúdo.

$$
\mathrm{S}_{1-----\mathrm{S}_{2}-----\mathrm{S}_{3}-----\mathrm{S}_{4}}
$$

Em análise, em $\mathrm{S}_{1}$ observamos o início de alguma coisa, que se finda em $\mathrm{S}_{4}$. Logo, $\mathrm{S}_{1}$ e $\mathrm{S}_{4}$ contêm limites simétricos e inversos, mesmo que seja possível prever a expansão desses limites. Os termos $\mathrm{S}_{2}$ e $\mathrm{S}_{3}$ são quebras no percurso, crescente ou decrescente, da cadeia. São contínuos com aumentações e diminuições representados em dimensões e subdimensões que, ao aumentarem ou diminuírem, produzem uma pausa para o sujeito da enunciação observada em restabelecimento e recrudecimento, para a aumentação, em atenuação e minimização, para a diminuição, entendidos como modulações aspectuais. Teremos ainda uma leitura relacionada à força das relações dos contrários, ou seja, a cadeia mostra intervalos fortes e fracos.

$$
\begin{aligned}
& \mathrm{S}_{1} \Leftrightarrow \mathrm{S}_{4} \rightarrow \text { forte contrário } \\
& \mathrm{S}_{2} \Leftrightarrow \mathrm{S}_{3} \rightarrow \text { fraco contrário }
\end{aligned}
$$


Serão sobrecontrarios os termos $\mathrm{S}_{1}$ e $\mathrm{S}_{4}$ e subcontrários os termos $\mathrm{S}_{2}$ e $\mathrm{S}_{3}$ compondo assim o que Zilberberg chama de matriz.

Figura 4 - Quadro I - Subcontrários/Sobrecontrários

\begin{tabular}{|c|c|c|c|}
\hline $\mathrm{S}_{1}$ & $\mathrm{~S}_{2}$ & $\mathrm{~S}_{3}$ & $\mathrm{~S}_{4}$ \\
$\downarrow$ & $\downarrow$ & $\downarrow$ & $\downarrow$ \\
minúsculo & pequeno & grande & imenso \\
$\downarrow$ & $\downarrow$ & $\downarrow$ & $\downarrow$ \\
Sobre-contrários & Sub-contrários & Sub-contrários & Sobre-contrários \\
Átono & Átono & Tônico & Tônico \\
\hline
\end{tabular}

As modulações aspectuais possíveis para esta cadeia, que pode conter variação de sentido atribuindo tônicos para $S_{1}$ e $S_{2}$ e átonos para $S_{3}$ e $S_{4}$, indicariam um percurso da compressão $\left[\mathrm{S}_{4}\right]$ até a atenuação $\left[\mathrm{S}_{1}\right]$, podendo ainda observar o sentido da aumentação como da recuperação $\left[\mathrm{S}_{1}\right]$ até a repetição $\left[\mathrm{S}_{4}\right]$. Indica-se ainda a possibilidade de outras relações entre termos:

\begin{abstract}
A partir das denominações propostas, diferentes relações semânticas podem ser consideradas. Se estivermos de acordo em designar a passagem do subcontrário para 0 sobrecontrário como uma convenção de signos que apontamos, por exemplo, / $\mathrm{S}_{2}$ /, ou seja, o termo /pequeno/, três relações simples de termo a termo podem ser feitas: (i) a relação $\left[\mathrm{S}_{2} \rightarrow \mathrm{S}_{3}\right.$ ] é uma convenção de graus próximos do superlativo gramatical e da gradação retórica; (ii) a relação $\left[\mathrm{S}_{2} \rightarrow \mathrm{S}_{4}\right]$ é uma conversão de graus seguida do signo perto da sublimação para sua amplitude; (iii) a relação $\left[\mathrm{S}_{2} \rightarrow \mathrm{S}_{1}\right]$ é uma dupla conversão de direção e de signos perto da hipérbole. Estas relações semânticas não são, portanto, estranhas à gramática ou retórica. (Zilberberg, 2012: 58) - tradução livre.
\end{abstract}

Nas relações entre grandezas, em seus pares, identificamos tonicidades ou atonicidades, indicadoras das subvalências associadas à subdimensão (ibidem). Aos olhos de Zilberberg, este é mais um ponto indicador de uma relação estrutural composta por índices de classes filiados a um grupo, e este ligado a um índice de individualidade. Parece, com isso, relembrar a disposição estrutural ligada à linguística indicando a retórica como argumento da eficiência do discurso.

Zilberberg mostra uma matriz composta com as subdimensões intensivas de tempo: rápido e lento. 
Figura 5 - Quadro II - Subcontrários/Sobrecontrários

\begin{tabular}{|c|c|c|c|}
\hline $\begin{array}{c}\text { Sobre-contr } \\
\text { Tônico }\end{array}$ & Sub-contr & Sub-contr & Sobre-contr \\
& Tônico & átono & Átono \\
\hline Apressado & Vívido & Lento & Arrastado \\
$\mathrm{S}_{1}$ & $\mathrm{~S}_{2}$ & $\mathrm{~S}_{3}$ & $\mathrm{~S}_{4}$ \\
\hline
\end{tabular}

Para o índice de classe atribuímos, visto que é condicional, o acento de sentido de acordo com o universo considerado do discurso. Formulada a matriz, passamos à sua observação no eixo tensivo ligando a intensidade da velocidade do rápido vs lento, com a extensidade da concentração vs difusão. O gráfico se apresenta desta forma:

Figura 6 - Gráfico Tensivo III - Cadeia de Termos

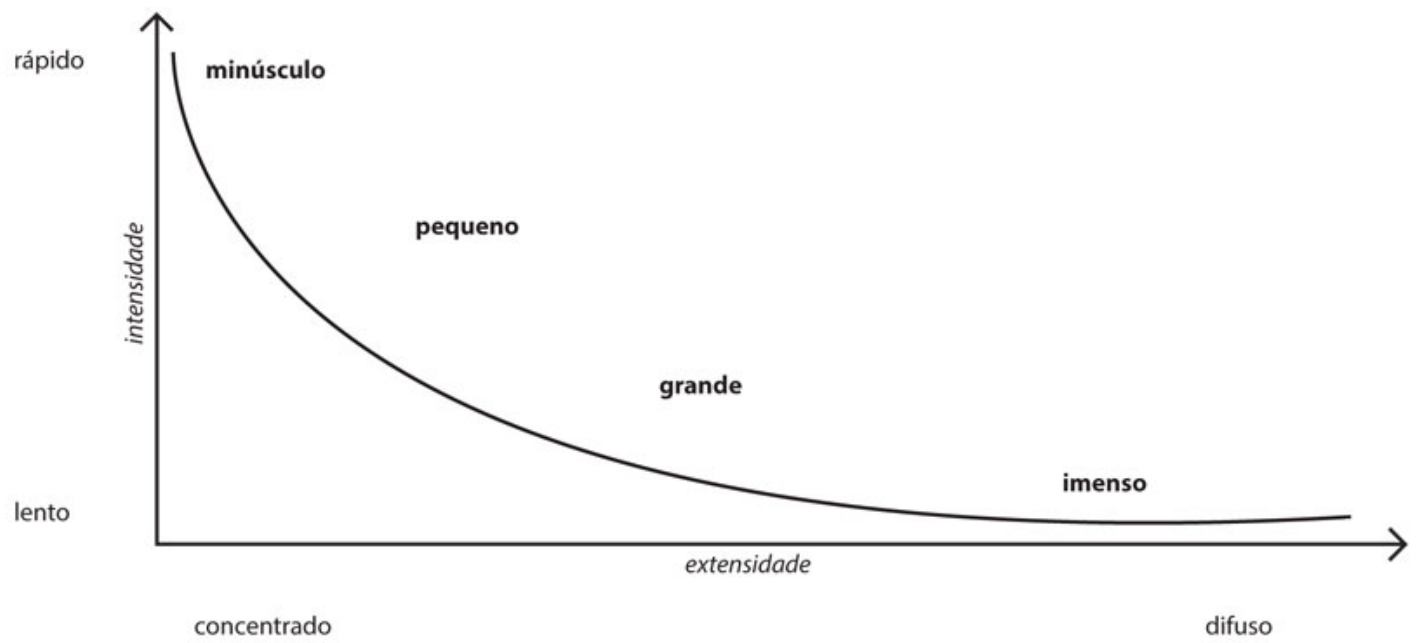

Se observado o movimento construído do concentrado/rápido até o difuso/lento tomaremos o sentido de atenuação; e o contrário, o restabelecimento. A cadeia dos termos produz a leitura do sintagma motivado que indica do "minúsculo” ao "pequeno”, do “pequeno” ao "grande” e do “grande” ao “imenso”, implicativos vistos da sequência em que se encontram. A concessão aparece como o possível diante do "não realizável”, logo, a leitura de uma sincope, um salto, entre termos: "Em resumo, os subcontrários entram no discurso convocando a implicação e os sobrecontrários, mobilizando a concessão” (ZILBERBERG, 2002: 197). A visão do concessivo representa o evento súbito, o susto, está ligado à experiência dos fatos, à visão do fenômeno ocorrido representado pelo acontecimento. 


\section{3 - O acontecimento}

Em um percurso, as ocorrências súbitas que desviam a sequência do contínuo “natural” são vistas como sobrevires que interrompem o devir. A maneira pela qual observamos essa ação é ordenada pelos modos semióticos de eficiência, de existência e de junção, e a ocorrência sincretizada desses modos nos mostrará o acontecimento. O acontecimento também é a ação que nos induz à leitura da intensidade, assim como demonstra a troca de estados do sujeito, indicando a variação possível do eixo da extensidade. Assim, via ordenação dos modos, o acontecimento evidencia as estruturas sintáxicas e semânticas, necessárias para a compreensão do objeto pelo sujeito, fazendo um paralelo com a teoria greimasiana ao se estabilizar também em três níveis: o morfológico, acima descrito, além dos níveis sintáxicos e o semânticos que ainda desenvolveremos.

Existe uma importante leitura de intervalos indicada por Zilberberg que altera o estado do sujeito, passando-o de sujeito da percepção para o sujeito da admiração. O intervalo entre o foco e seu objeto pode ser nomeado como esperado e, por sua vez, o intervalo entre a apreensão e seu objeto pode ser nomeado de inesperado. O aumento e a diminuição do intervalo tornará possível a mudança do estado do sujeito: por exemplo, o aumento, o inesperado, promoverá o sujeito da admiração diante do acontecimento; ou o seu inverso, a diminuição, o esperado, promoverá o sujeito da percepção “exposto às ‘coisas’ que não passam de ...'coisas””. (ZILBERBERG, 2011a: 164). A variação entre o acontecimento e os estados do sujeito é apontada como classificação figural, pertencente às “grandes polaridades estilísticas conhecidas” (idem: 166). Ou ainda, de acordo com a polaridade destacada pelo estudo estético no plano da expressão, que analisa os contrastes: entre cores, na harmonia musical, na acentuação poética, etc. (BERTRAND/STANGE, 2014). Dessa forma podemos observar a dualidade na categoria, a ocorrência entre acontecimentos e estados em um percurso, ou ainda, a concessão e a implicação observadas no percurso. Com efeito, essa polarização caracteriza a sintaxe tensiva que, "polariza e diferencia as grandezas solidárias do ponto de vista paradigmático tornando-se operacional ou operativa” (ZILBERBRG, 2012: 59). Na Semiótica Tensiva de Zilberberg, a leitura do acontecimento antagonista do estado foi alterada para a visão de um evento de ruptura, ou deslocamento, visto que se comporta como uma síncope na cadeia de termos, e um não-evento, portanto 
classificados como acontecimento e exercício. Essa abordagem descola a leitura do acontecimento ligado ao sujeito e o introduz na leitura da ação tensiva.

Figura 7 - Gráfico Tensivo IV - Acontecimento/Exercício

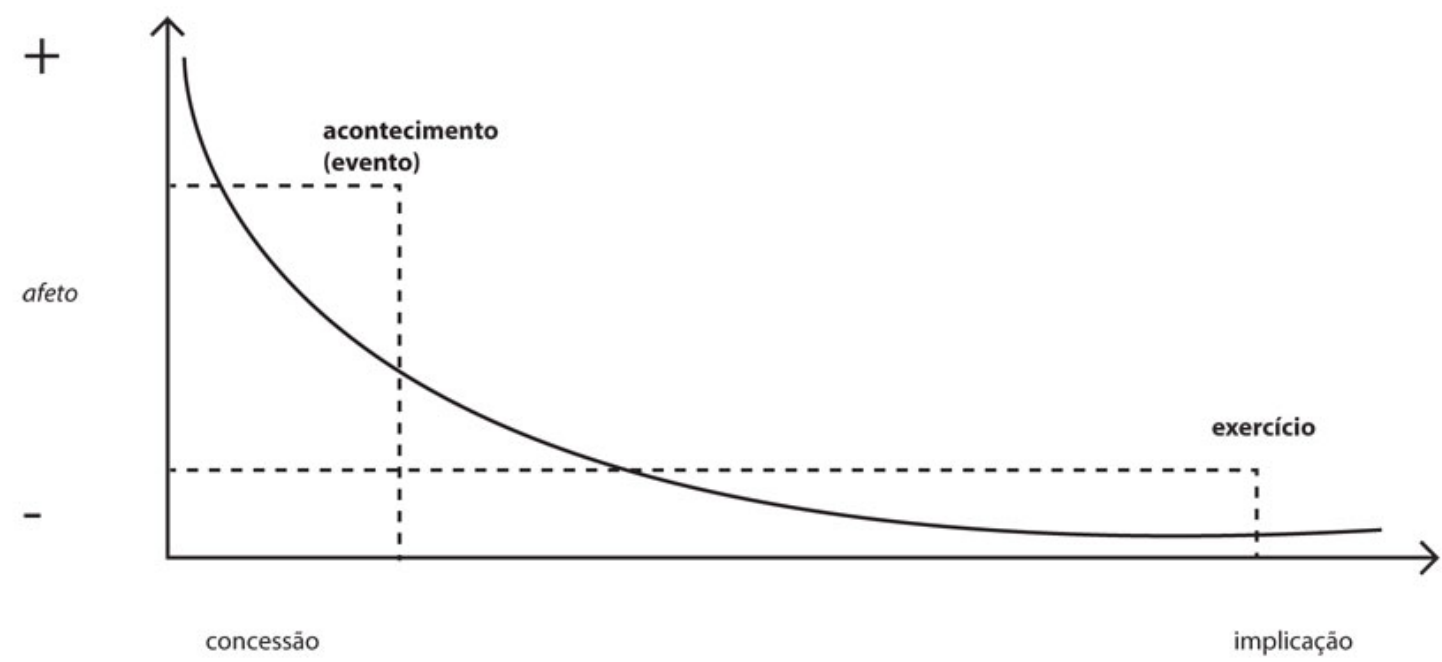

Passamos ao esclarecimento do acontecimento, uma localização dos estilos possíveis dentro da semiótica tensiva que tenham seus paralelos com os modos semióticos já citados, ou seja, uma sintaxe. A sintaxe tensiva se utiliza, assim como os modos, de três níveis de observação: a sintaxe intensiva, que trabalhará sob o regime de aumentações e diminuições; a sintaxe extensiva: que trabalhará sob o regime de triagem e de mistura e a sintaxe juntiva: que, da mesma forma, trabalhará o acontecimento e o exercício. Em sua estrutura, o acontecimento se apresenta como o sincretismo dos modos utilizando-se do sobrevir para o modo de eficiência, da apreensão para o modo de existência e da concessão para o modo da junção; em contra partida do exercício que se apresenta na mesma medida dos modos eficiência/existência/junção como: pervir/foco/implicação. A produção da estabilidade dos modos até as sintaxes serão avaliados da seguinte forma: 
Figura 8 - Quadro III - Modo/Sintaxe

\begin{tabular}{|c|c|c|}
\hline Modo semiótico & & Estilo sintáxico \\
\hline Modo de eficiência & $\rightarrow$ & Sintaxe intensiva \\
\hline (sobrevir vs pervir) & & (de aumentação e de diminuição) \\
\hline Modo de existência & $\rightarrow$ & Sintaxe extensiva \\
(foco vs apreensão) & & (triagem e mistura) \\
\hline Modo de junção & $\rightarrow$ & (o acontecimento e o exercício) \\
\hline (concessão vs implicação) & & \\
\hline
\end{tabular}

Zilberberg compartilha da posição de Greimas em posicionar o evento semiótico ligado a uma sintaxe e, posteriormente, a uma semântica. Seguindo o fenômeno do "susto", o sobrevir diante de um pervir, compomos a sintaxe juntiva com a ideia do acontecimento vs exercício. Contudo, a sintaxe juntiva tem por objetivo a observação das correlações entre a sintaxe intensiva e a sintaxe extensiva. No exemplo de Zilberberg, duas aumentações relacionadas entre si e em um mesmo eixo intensivo de extensidades diferentes poderá, pela sintaxe juntiva, mostrar posições do acontecimento e do exercício. Isso ocorre pela ação “implicativa causal à proposição subordinada concessiva” (ZILBERBERG, 2012: 61), ou seja, à descoberta da concessão quando subordinada a implicações pelos eixos intensivos e extensivos. Esse exemplo simples efetiva a importância da sintaxe juntiva: ela fará a leitura dos implicativos, subcontrários, promovendo o conhecimento do sintagma elementar, a matriz. A juntiva também faz conhecer as estruturas afins, atribuindo índices aos subcontrários, atribuindo-lhes um termo e uma operação que resultam em sintagmas, menores, estes transitivos ou reflexivos. O exemplo dado por Zilberberg mostra as implicações aberto vs fechado executando a matriz:

$$
\text { escancarado - aberto - fechado - hermético }
$$

Atribuindo-lhe o termo [o abrir] e [o fechar], e a operação [abrir] e [fechar], organizaremos uma estrutura reconhecendo as formas reflexivas e transitivas: 
Figura 9 - Quadro IV - Reflexivo/Transitivo

\begin{tabular}{l|c|cc} 
Termo & Operação & $\begin{array}{c}\text { Oabrir } \\
\text { a1 }\end{array}$ & $\begin{array}{c}\text { O fechar } \\
\text { b2 }\end{array}$ \\
\hline $\begin{array}{c}\text { Abrir } \\
\text { a1 }\end{array}$ & $\begin{array}{c}\text { Abrir o aberto } \\
\text { a1/a2 Reflexivo }\end{array}$ & Transitivo & $\begin{array}{c}\text { Abrir o fechado } \\
\text { a1/b2 }\end{array}$ \\
\hline $\begin{array}{c}\text { Fechar } \\
\text { b2 }\end{array}$ & $\begin{array}{c}\text { Fechar o aberto } \\
\text { b1/a2 Transitivo }\end{array}$ & Reflexivo & $\begin{array}{c}\text { Fechar o fechado } \\
\text { b1/b2 }\end{array}$ \\
\hline
\end{tabular}

Os sintagmas transitivos [b1/a2] e [a1/b2] são motivados e implicativos, além de reconhecidos como exercícios (ZILBERBERG, 2012: 62); os sintagmas reflexivos [a1/a2] e [b1/b2] não são motivados e são concessivos, indicadores de acontecimento. Por serem reflexivos são chamados de "bizarros" e inesperados: no discurso dão a ideia de "embora este dispositivo esteja aberto, eu o abri!”5 (ibidem). Essa relação torna importante a sintaxe juntiva, pois esclarece o sintagma transitivo-implicativo e o sintagma reflexivo-concessivo, sendo estes banais e bizarros respectivamente.

Zilberberg vai além ao anunciar a busca de uma ênfase, no plano do conteúdo, compreendendo uma ultrapassagem no limite da concessão. Indica o limite do sublime como valência mais forte compondo uma ultrapassagem:

Figura 10 - Quadro V - Ênfase

\begin{tabular}{|c|c|c|}
\hline Eu alongo o curto & Eu alongo o longo & Eu alongo o já longo \\
$\downarrow$ & $\downarrow$ & $\downarrow$ \\
\hline Remoção & Reforço & Ultrapassando \\
\hline Superlativo-implicativo & Superlativo-concessivo & O sublime \\
\hline
\end{tabular}

Aqui o autor aponta uma nova aderência à retórica, provavelmente relacionando a ênfase à hipérbole, ou a outra figura da repetição/sobreposição. A sequência da

\footnotetext{
${ }^{5}$ O original dessa citação é "bien que ce dispositif soit déjà ouvert, je l'ouvre!" (ZILBERBERG, 2012: 62). Está traduzida para o espanhol na publicação de Desiderio Blanco como: " $i$ a pesar de que este espacio est á ya abierto, lo abriré más!" - ZILBERBERG, Claude. La estrutura tensiva. Lima: Universidad de Lima, 2016. posição 1030 de 3014 - 35\%
} 
explicação da teoria expõe outros pontos da argumentação retórica contidos na sintaxe juntiva. O paradoxo, contrário à doxa, é visto pela observação da ação da concessão: por um lado, a concessão funciona como uma implicação desfeita, que a própria concessão desmontou: precisamente, a concessão desfaz a ruptura extensiva da implicação (ZILBERBERG, 2012: 64); e ainda pode formar uma atualização do enunciado quando a concessão desvia a "verdade" doxal. No exemplo dado por Zilberberg podemos perceber a ação discursiva proposta:

A enunciação: embora ele seja excelente, falhou, pressupõe a verdade da enunciação, todos que são excelentes vencem. Essa extensidade é um defeito em francês por esta pequena palavra "salvo", que se torna a singularidade ou um acontecimento. Por outro lado, a relação de implicação à realização da concessão toma a forma de uma atualização de enunciação: ele teria ganhado uma vez que é excelente; o entimema não está longe, mas a concessão leva ao limite a carga fiduciária da implicação doxal (Zilberberg, 2012: 64). ${ }^{6}$ - grifos originais - tradução livre.

Zilberberg explica a ação das repetições, retóricas ou hiperbólicas ligadas à ênfase, à ultrapassagem, como formadores da percepção do afeto no discurso. O afeto é o resultado da dependência estrutural existente nos processos de implicação e concessão geradores dos saltos e das ênfases. Esta grandeza que “supera a concessão”, é apontada pela falha de adaptação, o choque, etc. Afirma:

A emoção disfórica ocorre quando duas grandezas próximas recusam-se a se interpenetrar, a se 'comunicar' umas com as outras, enquanto a emoção eufórica toma forma quando duas grandezas coexistem, através de suas aberturas comuns. A emoção é percebida pelas perspectivas de acessibilidade e de obstrução. Como sempre indica Valéry: 'Ser afetado, é, antes de tudo, ser invadido'. - (Zilberberg, 2012: 66). - grifos originais - tradução livre.

Passamos a observar a intensidade sendo não apenas uma demonstração do aumentar ou diminuir de algum evento, mas o aumentar o aumentado ou diminuir o diminuto, assim como as operações transitivas. A sintaxe intensiva mostrará a circularidade do fazer, que aumenta ou diminui, do sujeito, percebido pelo plano do conteúdo e tratado pelas grandezas existentes no plano da expressão. Zilberberg admite os “mais” e os “menos” como grandezas mínimas indispensáveis à sintaxe intensiva. Estas são intercruzadas, proporcionando quatro termos estruturados. Ele se apoia na implosão/explosão da sílaba propostas por Saussure, desde que as duas grandezas não

\footnotetext{
${ }^{6}$ A expressão "leva ao limite a carga fiduciária" foi livremente traduzida da sequência "entame à la marge la charge fiduciaire".
} 
sejam nem vocálicas e nem consonantais, mas, a combinação dessas como característica de uma sílaba ${ }^{7}$.

Figura 11 - Quadro VI - Aumentação/Diminuição

\begin{tabular}{|c|c|c|}
\hline & Aumentação & Diminuição \\
\hline Aumentar & aumentar uma aumentação & aumentar uma diminuição \\
$\rightarrow$ ultrapassagem & $\rightarrow$ extenuação \\
& $\approx$ adição de um mais & $\approx$ adição de um menos \\
\hline Diminuir & $\begin{array}{c}\text { diminuir uma aumentação } \\
\rightarrow \text { moderação }\end{array}$ & $\begin{array}{c}\text { diminuir uma diminuição } \\
\text { redução }\end{array}$ \\
& $\approx$ retirada de um mais & $\approx$ retirada de um menos \\
\hline
\end{tabular}

Aqui, cada termo é sujeito a outro pela adição ou subtração de “mais” ou "menos" de forma estrutural:

(...) adicionando mais um, ele pode aumentar uma aumentação anterior e tomar a forma de uma ultrapassagem, ou adicionando menos aumento em uma diminuição levar a forma de extenuação que será chamado de novo ou suplementar. Sob as mesmas condições, pode diminuir por remoção de um mais colocado na aumentação e assim modera-se, ou através da remoção de um menos na diminuição será reduzida. -(Zilberberg, 2012: 67). - grifos originais - tradução livre.

Além de olhar para as aumentações e diminuições, devemos olhar para as séries, as coleções, as multiplicidades, as aglomerações que a sintaxe extensiva prevê e observa em concentração e difusão. Nesse ponto, atribuímos a noção de triagem e mistura para a concentração e a difusão respectivamente, apontando a recursividade dessas tensões como o núcleo da sintaxe extensiva. Elas podem ser atribuídas ainda ao ponto de vista figural onde a triagem age como operadora e a mistura como objeto (ZILBERBERG, 2012: 68). A concessão e a implicação unem-se ao eixo extensivo gerando (i) uma triagem concessiva: a expulsão provocada pelo súbito sobrevir; (ii) uma mistura implicativa: a purificação relativa a doxa; (iii) uma mistura concessiva: a intrusão do acontecimento; e (iv) uma mistura implicativa: a união sutil.

\footnotetext{
${ }^{7}$ Zilberberg indica o Princípios de Fonologia de Ferdinand de Saussure. Publicação anterior à formação do Curso de Linguística Geral.

${ }^{8} \mathrm{O}$ termo usado por Zilberberg (2012: 67) é o de comblement. Aqui o termo está atualizado conforme o quadro da página 60 do livro Elementos de Semiótica Tensiva do mesmo autor (2011a) já traduzido para o português.
} 
Figura 12 - Quadro VII - Operação/Junção

\begin{tabular}{|c|c|c|c|}
\hline $\begin{array}{c}\text { Operação } \\
\downarrow\end{array}$ & Junção $\rightarrow$ & $\begin{array}{c}\text { Concessão } \\
\downarrow\end{array}$ & $\begin{array}{c}\text { Implicação } \\
\downarrow\end{array}$ \\
\hline \multicolumn{2}{|c|}{ Triagem $\rightarrow$} & Expulsão & Purificação \\
\hline \multicolumn{2}{|c|}{ Mistura $\rightarrow$} & Intrusão & União \\
\hline
\end{tabular}

Podemos fazer a leitura de uma estrutura utilizando o termo e a operação. Teremos então a visão do transitivo e do reflexivo nas operações de triagem e mistura.

Se a sintaxe intensiva, preocupada com o brilho, procede por aumentar e diminuir, a sintaxe extensiva, preocupada com a pureza, intervém pela operação de triagem e mistura que estão de acordo com os casos transitivos e reflexivos. Essas operações são transitivas em dois casos: quando a triagem é caracterizada por uma mistura anterior, ou quando a mistura é caracterizada por uma triagem anterior. Elas são reflexivas quando a mistura retorna sobre uma mistura já feita; da mesma forma quando a operação de triagem retorna sobre uma triagem já feita. - (Zilberberg, 2012: 69). - grifos originaistradução livre

A montagem da descrição acima se apresenta da seguinte forma:

Figura 13 - Quadro VIII - Operação/Termo

\begin{tabular}{|c|c|c|c|}
\hline operação $\downarrow$ & termo $\rightarrow$ & mistura & triagem \\
& $\downarrow$ & $\downarrow$ \\
\hline Misturar $\rightarrow$ & Misturar uma mistura & Misturar uma triagem \\
& $\approx$ fundir & $\approx$ confundir \\
\hline Triar $\rightarrow$ & Triar uma mistura & Triar uma triagem \\
& $\approx$ dividir & $\approx$ fracionar $^{9}$ \\
\hline
\end{tabular}

As distribuições das transitividades e das reflexibilidades apontam para uma formação de sintagmas implicativo e reflexivo respectivamente. Assim teremos na disposição do sintagma implicativo o triar uma mistura e o misturar uma triagem, assim como no sintagma reflexivo o triar uma triagem e o misturar uma mistura.

\footnotetext{
${ }^{9}$ O termo usado por Zilberberg (2012: 69) é disséminer. Porém, logo depois o autor faz referência ao ato da dupla triagem como "espalhar em numerosos pontos independentes" - "répandre en de nombreux points assez écartés". Com efeito, afasta do termo proposto por se relacionar ao propagar, difundir, espalhar, distantes da significação em português.
} 
Posto o método da sintaxe, podemos adentrar o desenvolvimento sugerido por Zilberberg relacionado à análise semântica. Por comporem-se umas às outras, a sintaxe e a semântica podem ser observadas em proximidade em uma análise e, também, como já preconizado por Greimas, podem participar de cada nível, assim como desenvolvido no percurso gerativo do sentido . A composição de uma semântica tensiva parece apoiar-se na ideia de que esta pode ampliar o conteúdo sobre a sintaxe. Ou seja, uma semântica pode compor mais de um sentido em apenas uma sintaxe. Por manterem um acordo estrutural, a semântica tensiva também é observada em três níveis: uma semântica juntiva, uma semântica intensiva e uma semântica extensiva (ZILBERBERG, 2012: 70-7). Na semântica juntiva encontramos a semântica intensiva: promotora da medida e da subvalência do supremo; e a semântica extensiva: indicadora do universal ou exclusivo dentro de nosso universo discursivo (ZILBERBERG, 2012: 70-1). Aqui é onde passamos a nos interessar pelo afeto e onde o "sujeito se compromete a sentir e, por catálise, experimentar” (idem: 71). Assim, o afeto pode ser avaliado a partir de uma desigualdade súbita, uma excitação, um movimento da subvalência intensiva. $O$ movimento desigual voltará ao seu movimento inicial compondo uma dissipação. Movimentando-se entre saltos e restabelecimentos, pode-se perceber que o evento é visto como (i) uma desigualdade súbita geradora de excitação e (ii) uma desigualdade dissipada geradora de espera: como "vagas" que indicam um "sempre recomeçar" (idem: 71-2).

Este pulso fundamental retorna o alguma coisa ao acontecimento, ao acento, e o nada à defecção, ao desafeto. A direção do ser seria menos declarativa que exclamativa, e, desde que a linearização é imperativa, rítmica na medida em que a espera se encontra no princípio da célula rítmica (...) - tradução livre - (Zilberberg, 2012: 72). - grifos originais

A percepção do ritmo é causada pela leitura do movimento entre espera e o estupor. Muito semelhante à concepção de ritmo descrito no Dicionário de Semiótica (GREIMAS/COURTÉS, 1999), que o considera uma espera aplicada a intervalos recorrentes entre agrupamentos, um ostinato ${ }^{10}$, definidor do “movimento" do discurso.

\footnotetext{
${ }^{10}$ Ostinato é um termo musical que reconhece as repetições de um padrão: seja melódico, rítmico ou harmônico. Uma progressão ou um ralento podem ser também considerados ostinatos se repetirem algum padrão reconhecível. - SADIE, Stanley. (Ed.) Dicionário Grove de Música: Edição concisa. Rio de Janeiro: Jorge Zahar, 1994.
} 
A semântica intensiva e a semântica extensiva comporão o ritmo tensivo em duas características para cada eixo. No caso da Semântica intensiva, ( $i_{1}$ ) pode se apresentar como cumulativa, por manter a prevalência do modo de eficiência, quando a aumentação/diminuição obedecerem o pervir; $\left(\mathrm{ii}_{1}\right)$ pode se apresentar como culminativa quando obedece o sobrevir, o acontecimento. Na semântica extensiva pode variar entre, ( $\left.\mathrm{i}_{2}\right)$ o número, quando a intensidade tem essa determinação numérica; (ii ${ }_{2}$ ) a dimensão [concentrado vs difuso] por fazer parte da característica do eixo da extensidade. Sob os termos dados às características das semânticas intensivas e extensivas, podemos distinguir matrizes para cada eixo. Assim como nas semânticas intensivas e extensivas, uniremos a estas mais uma matriz ligada à semântica juntiva operada pela já citada [excitação vs espera]. O resultado das operações dessas matrizes compõem uma rede de termos em associação com as iniciativas entre átonos e tônicos alocados nos subcontrários ou sobrecontrários. O resultado das matrizes se apresenta assim:

Figura 14 - Quadro IX - Matriz

\begin{tabular}{|c|c|c|c|c|}
\hline Matriz $\rightarrow$ & $\begin{array}{c}\text { Sobrecontrário } \\
\text { Átono } \\
\downarrow\end{array}$ & $\begin{array}{c}\text { Subcontrário } \\
\text { Átono } \\
\downarrow\end{array}$ & $\begin{array}{c}\text { Subcontrário } \\
\text { Tônico } \\
\downarrow\end{array}$ & $\begin{array}{c}\text { Sobrecontrário } \\
\text { Tônico } \\
\downarrow\end{array}$ \\
\hline $\begin{array}{c}\text { Semântica } \\
\text { intensiva } \rightarrow\end{array}$ & nulo & fraco & forte & supremo \\
\hline $\begin{array}{c}\text { Semântica } \\
\text { extensiva } \rightarrow\end{array}$ & universal & comum & raro & exclusivo \\
\hline $\begin{array}{c}\text { Semântica } \\
\text { juntiva } \rightarrow\end{array}$ & necessário & esperado & inesperado & surpreendente \\
\hline
\end{tabular}

Zilberberg apresenta uma leitura integrada entre a sintaxe tensiva e a semântica tensiva. A sintaxe é representada por movimentos, as transposições indicadas por Zilberberg, estes movimentos são estabelecidos pelos termos das matrizes semânticas. A composição da integração estabelece a composição da matriz e sua estrutura em paradigmas semânticos e sintáxicos: 
Figura 15 - Quadro X - Sintaxe/Semântica

\begin{tabular}{|c|c|c|c|c|}
\hline $\begin{array}{c}\text { Matriz } \rightarrow \\
\text { Paradigma } \\
\downarrow\end{array}$ & $\begin{array}{c}\text { Sobre contrário } \\
\text { Átono } \\
\downarrow\end{array}$ & $\begin{array}{c}\text { Sub contrário } \\
\text { Átono } \\
\downarrow\end{array}$ & $\begin{array}{c}\text { Sub contrário } \\
\text { Tônico } \\
\downarrow\end{array}$ & $\begin{array}{c}\text { Sobre contrário } \\
\text { Tônico } \\
\downarrow\end{array}$ \\
\hline $\begin{array}{c}\text { Semântica } \\
\text { intensiva } \rightarrow\end{array}$ & nulo & Fraco & forte & supremo \\
\hline $\begin{array}{c}\text { Sintaxe } \\
\text { intensiva } \rightarrow\end{array}$ & Dimi & ção & aum & tação \\
\hline $\begin{array}{c}\text { Semântica } \\
\text { extensiva } \rightarrow\end{array}$ & universal & comum & raro & Exclusivo \\
\hline $\begin{array}{c}\text { Sintaxe } \\
\text { extensiva } \rightarrow\end{array}$ & \multicolumn{2}{|c|}{ mistura } & \multicolumn{2}{|c|}{ triagem } \\
\hline $\begin{array}{l}\text { Semântica } \\
\text { juntiva } \rightarrow\end{array}$ & necessário & esperado & inesperado & Surpreendente \\
\hline $\begin{array}{c}\text { Sintaxe } \\
\text { juntiva } \rightarrow\end{array}$ & \multicolumn{2}{|c|}{ implicação } & \multicolumn{2}{|c|}{ concessão } \\
\hline
\end{tabular}

Observamos a composição do acontecimento da semiótica tensiva organizado pelas oposições dos subcontrários. A movimentação da sintaxe: diminuição/aumentação, mistura/triagem, implicação/concessão; desenvolve-se a partir das oposições semântica, respectivamente: fraco/forte, comum/raro, esperado/inesperado. Podemos supor o percurso inverso na composição do método de observação da semiótica tensiva, ou seja, da movimentação da sintaxe estabelecendo as oposições iniciais indicadoras dos termos da matriz. Por serem do âmbito de um fazer, a sintaxe tensiva pode ser colocada em paralelo com a retórica: ambas trabalham a composição da manipulação no acontecimento.

(...) a aparente conivência entre a retórica e a sintaxe tensiva merece reflexão: a gramática tensiva sucede do seu saber, enquanto que a retórica em princípio convida o fazer, mas essa solução de continuidade é temperada, nos parece, pela seguinte disposição: as definições das figuras, em particular na obra de Fontanier, constituem uma mediação entre a sintaxe tensiva e a retórica, um detalhe aqui, sabendo que a sintaxe tensiva é por um instante muito anterior à retórica. - (Zilberberg, 2012: 77). grifos originais - tradução livre. 
Encontraremos uma dupla articulação do objeto semiótico: do lado da semântica intensiva, um objeto pode ser visto como intensidades e brilho, de afeição, e, pelo impacto de sua aparição, gerador de um brilho/afeição verdadeiros; do lado da semântica extensiva, podemos entender um índice de composição diferenciador de suas qualidades quanto à raridade, sua popularidade, sua familiaridade, etc., assim como sua fixação ou diluição, sua divisão ou confirmação de unicidade diante do evento intensivo: "o número de extensidade funciona como um divisor no que diz respeito à intensidade” (idem, p.77).

Dos modos semióticos, passando pela sintaxe tensiva e chegando à semântica tensiva, temos a apresentação do acontecimento. Este é composto em graus, com repetições e acréscimos, ou estagnações e subtrações, formador de um ritmo tensivo e promotor do entendimento do afeto. Os graus representados na análise, assim como sua frequência e intensidade, estão ligados ao que Zilberberg indica como acréscimo em nosso permanente “quantum imaginário de cargas tímicas” (2012: 29).

\section{4 - O ritmo}

Cada evento semiótico que nos propomos a observar é analisado pelos fragmentos deixados na estrutura tensiva. A busca nessa análise é a compreensão do afeto envolvido no evento. Com isso, através de valências e sub valências dispostas em eixos de intensidade e extensidade, encontraremos a rede de relações indicadoras do afeto. Assim, percebemos um ritmo criado pelo movimento dos acontecimentos.

Na verdade, a percepção geral do evento, o pervir, e este entre vagas de acontecimentos e exercícios, cria a sensação de expectativa diante do discurso. É a reação ao efeito de espera, característica da formação do ritmo, desenvolvida no discurso que, em análise, movimenta suas relações temporais. O ritmo pode ser representado pela intersecção das valências de tonicidade, vinculada à intensidade, e de temporalidade, relacionada à extensidade. A posição da intensidade, portanto detentora da atribuição do afeto, atua como regente da extensidade. O efeito apreendido é o da coexistência do sujeito sobre duas bases, ou melhor, sobre duas subvalências da tonicidade: 
(...) o sujeito segundo a intensidade e o sujeito segundo a extensidade estão destinados a coexistir, a conviver em razão de sua divergência: o sujeito sensível, por catálise sensível $a$, é um paciente, esforçando-se para potencializar a subversão que as valências extremas do andamento e da tonicidade nele desencadeiam. $O$ que torna inexoravelmente passivo o sujeito sensível é a magnitude dos destinos, para não dizer, dos golpes que o atingem: (i) considerando a subdimensão do andamento, é um sujeito do sobrevir, isto é, um sujeito sobrecarregado, a emitir, contra a vontade, um tempo negativo que ele próprio se sente na obrigação de reduzir; (ii) considerando a subdimensão da tonicidade, é um sujeito do paroxismo, um sujeito segundo o estupor, privado dos espaços familiares e das faculdades de antecipação que o tranquilizam. (Zilberberg, 2010: 3). - grifos originais

Essa dominância da intensidade necessita de adaptação que, como indica o autor, a condição de relações mútuas no espaço tensivo entre a intensidade e a extensidade deve ser reordenada quando descreve uma observação do ritmo. Por serem desiguais, Zilberberg evoca o conceito de funtivo regido e funtivo regente de Hjelmslev, ordenando a intensidade como regente da extensidade quando se apoia no conceito de recção ${ }^{11}$. Podemos com isso localizar a “adaptação” entre categorias, regente e regida, submetendo as subvalências ao conceito de recção linguística: chegaremos a uma subordinação e à conclusão de uma regência intensiva da tonicidade sobre o regido extensivo da temporalidade, em outros termos, o afeto regente do inteligível, e do tempo, capaz de mostrar a disposição do ritmo. Zilberberg aponta ainda o paroxismo existente no estupor da subvalência do acontecimento e que, também pela preponderância da tonicidade, faz deduzir momentos de redução, indicadores de uma “calma” promotora da espera e, consequentemente, de uma expectativa. Na intensidade regente, as subvalências ordenarão a transformação do sujeito pelo sobrevir, do andamento, do paroxismo, e da tonicidade, levando-o do fazer ao sofrer. Analisamos dessa forma uma breve atividade comutativa que parece suspender o sujeito subitamente quando as "emoções regem nossas identidades actanciais, em função das valências imperiosas que sustentam” (ZILBERBERG, 2010: 3).

Para localizar o ritmo dentro do estudo da semiótica tensiva, Zilberberg aborda a característica complexa da rede de subvalências. De fato, ao conceber a temporalidade e a espacialidade no eixo extensivo e, da mesma forma, o andamento e a tonicidade como intensivo, entendemos a classificação dos aspectos, intensivo e extensivo ou qualquer outro aspecto que a análise venha a requerer, como produtos das duas subvalências, e não como o resultado da soma dos dois sub-termos. O conceito de complexidade é expandido com o argumento da estrutura com entidades autônomas de dependências

\footnotetext{
${ }^{11}$ A recção será tratada mais adiante no item "Predicação".
} 
internas (HJELMSLEV, 1991: 29) que entende a interação entre grandezas, em detrimento de sua oposição ou de sua soma. O produto dessa interação é possível ser representado por um quadro em rede que, considerando nosso objeto, passa a ser observado pelos seus feixes de relações. O relacionamento do feixe em rede pode ser distribuído assim:

Figura 16 - Quadro XI - Feixe de relações

\begin{tabular}{|l|l|l|l|}
\hline Intensidade $\downarrow$ & Extensidade $\rightarrow$ & Temporalidade & Espacialidade \\
\hline Andamento & Acontecimento & Ubiquidade \\
\hline Tonicidade & Ritmo & Profundidade \\
\hline
\end{tabular}

O ritmo pode assim ser visto no espaço tensivo como a intersecção entre a tonicidade regente e a temporalidade regida. Expõe assim a verdade sobre o caráter classificatório em que o ritmo se encontra, ou seja, utilizando-se das composições das subvalências, e não uma substância de difícil localização e utilização em uma análise. Distribuído dessa forma, podemos afirmar algumas características do ritmo como: (i) sobre a intensidade, sendo da composição do ritmo a tonicidade, atribuiremos a ele a tensão [tônico vs átono]; (ii) sobre a extensidade devemos efetuar uma divisão, a pedido de Zilberberg, e apontar três temporalidades que serão vinculadas a estilos rítmicos (ZILBERBERG, 2010: 6). Cada uma das três temporalidades abrirá ao sujeito mais formas de comutar, além daquela que o suspende, mas agora, sobre a base da extensidade. Aqui reaparecem as valências de foco e apreensão, apresentadas anteriormente como sendo do modo de existência e ligadas ao acontecimento súbito diante do mesmo sujeito. Com isso, tratamos novamente de parte dos modos semióticos, dessa vez, sem atribuições sobre a implicação e a concessão, mas restringindo-os no eixo da temporalidade. Assim, (a) a tensão foco/apreensão está ligada ao paradigma intitulado por Zilberberg como tempo diretivo das volições, uma percepção ligada à constância das rupturas e dos descansos, aqui a expectativa já é argumentada, uma vez que espera a sequência do acontecimento; (b) se observados os tempos fortes e fracos na extensão temporal completa, encontraremos a necessidade de explorar o antes e o depois dos eventos. A colocação de Zilberberg para essa posição inclui a posição no 
plano do conteúdo com o "engajamento actancial” da [pergunta vs resposta] indicando, com clareza, a pergunta anterior à resposta. O autor completa:

É preciso, porém, ir mais longe: pergunta e resposta são funtivos de uma função tensiva da maior relevância, a espera. A pergunta que não obtém satisfação imediata muda o presente em espera; esta não é nada mais que a pergunta de uma resposta que tarda. (Zilberberg, 2010, p.6)

Podemos perceber também a atribuição da expectativa, a espera, como argumento maior na formação do ritmo. A espera tem por indicação a cesura, a interrupção, que leva ao aparecimento de mais um evento. (c) O tempo fórico das extensões opera entre abreviações e alongamentos. Esta temporalidade terá ação junto à tonicidade como reação aos acentos tônicos e átonos uma vez que, segundo Zilberberg, os acentos tônicos alongam a duração, enquanto que a atonização abrevia a duração.

Figura 17 - Quadro XII - Temporalidade

\begin{tabular}{|c|c|c|c|}
\hline Tonicidade & \multicolumn{3}{|c|}{ Temporalidade } \\
\hline \multirow{2}{*}{ Tônico vs átono } & $\begin{array}{c}\text { Paradigma } \\
\text { do tempo diretivo }\end{array}$ & $\begin{array}{c}\text { Paradigma } \\
\text { do tempo } \\
\text { demarcativo } \\
\text { das posições }\end{array}$ & $\begin{array}{c}\text { Paradigma } \\
\text { do tempo fórico } \\
\text { das extensões } \\
\downarrow\end{array}$ \\
$\downarrow$ & Valência & Valência & Valência \\
& Foco vs apreensão & Anterioridade vs & duração vc brevidade \\
& & posterioridade & \\
\hline
\end{tabular}

Com isso Zilberberg "divide” a observação sobre o tempo em três conceitos: o olhar sobre o sujeito para o foco/apreensão, visto da ocorrência do "susto" e a recuperação posterior; o olhar sobre a localização temporal com anterioridade/posterioridade e o olhar sobre a continuidade com duração/brevidade. Podemos supor uma relação entre sujeito/local/continuidade com o ego/hic/nunc da enunciação, embora sem a temporalidade natural da observação dos eventos, mas com a mistura do tempo/espaço no mesmo eixo: ou seja, aqui o hic ficaria relacionado ao espaço da enunciação. Assim, a enunciação, descrita no eixo da extensividade, portanto 
temporalidade na análise do ritmo, poderá ser observada como produto do ego/hic/nunc em coexistência à tonicidade do eixo intensivo.

Zilberberg aponta ainda possibilidades de observação de eventos com análises direcionadas às outras grandezas da rede de relação complexas: a profundidade, a ubiquidade e o acontecimento. A profundidade descrita por Zilberberg (2010) é resultante da mesma rede de relações complexas, portanto sem uma definição por oposições ou somas, produto da tonicidade e da espacialidade, eixo intensivo para a tonicidade e eixo extensivo para a espacialidade. Assim como no ritmo, o autor articula as possibilidades de paradigmas, assim como suas resultantes valências, diante da órbita da espacialidade, muito semelhante ao que fez com o ritmo na órbita da temporalidade, porém ambas sob a regência da tonicidade e a tensão entre [tônico e átono].

Figura 18 - Quadro XIII - Espacialidade

\begin{tabular}{|c|c|c|c|}
\hline Tonicidade & \multicolumn{3}{|c|}{ Espacialidade } \\
\hline \multirow{2}{*}{ Tônico vs átono } & $\begin{array}{c}\text { Paradigma } \\
\text { do espaço diretivo }\end{array}$ & $\begin{array}{c}\text { Paradigma } \\
\text { do espaço } \\
\text { demarcativo } \\
\text { das posições }\end{array}$ & $\begin{array}{c}\text { Paradigma } \\
\text { do espaço fórico } \\
\text { dos ímpetos (elãs) } \\
\downarrow\end{array}$ \\
& das volições & $\downarrow$ & Valência \\
& Valência & Valência & repouso vc \\
& Aberto vs fechado & movimento \\
& & interioridade & \\
\hline
\end{tabular}

Nos interessa a questão teórica de que a profundidade mede a distância entre os termos extremos dos sobrecontrários, esse intervalo mede o afeto e, através desse afeto manifestado, encontramos a intensidade:

(...) esses intervalos, por sua pertinência ao espaço tensivo, medem, se assim podemos pensar, os afetos; a profundidade revela a intensidade, ou seja, a primeira manifesta a segunda no ato de despendê-la, do mesmo modo como a exprime ao manifestá-la. (Zilberberg, 2010: 9) 
O desenvolvimento do argumento da profundidade completa a descrição sobre as cadeias de termos complexos: os subcontrários e sobre contrários. Com isso, ritmo e profundidade passam a participar da análise por conterem posições de intersecção entre valências. Essa possibilidade de “aproveitamento” das valências proporciona maiores comutações e, com isso, mais campo de observação, além do fato de que, por repousarem sobre a tonicidade, compreendem a variação de paradigmas e suas consequentes valências, o que não ocorre na grandeza do acontecimento e da ubiquidade.

O acontecimento, desenvolvido a partir do produto das valências de andamento e temporalidade, contêm as subvalências do andamento, o sobrevir e o pervir, trabalhando em intersecção com a temporalidade extensiva. Como visto no capítulo anterior, a compreensão do acontecimento auxilia na análise do afeto e, em vista da introdução do ritmo, alerta para a mudança da observação do tempo diante dos eventos do acontecimento:

O andamento precipitado do acontecimento resulta numa síncope da temporalidade: o tempo estará momentaneamente fora dos eixos enquanto o assomo de um impacto estiver sendo experimentado pelo sujeito. Todo impacto, porém, está destinado a resolver-se em descendência, a não ser que surja um contraprograma credível de retenção. Por isso, o tempo fórico logo retoma seus direitos, mas esse tempo que regressa é um tempo sob o signo da apreensão, pois a superlatividade do impacto o torna imediatamente memorável: só o intenso é memorável. (Zilberberg, 2010: 10)

O tempo “fora do eixo" refere-se ao efeito que o sobrevir incide, a variação temporal que faz perceber a rapidez do ato como um freio temporal. Só a reposição da percepção do sujeito é que fará a retomada temporal, o movimento do tempo fórico dos ímpetos (elãs).

A ubiquidade é considerada como uma modalidade de “difusão” por estar em muitos lugares ao mesmo tempo aos olhos do observador. Como indica Zilberberg, pode compor um ponto de vista quando observada a reprodutibilidade técnica nos meios produtivos e de comunicação (2010). Fruto da intersecção entre andamento e a espacialidade, considera a relação da produção industrial relacionando-os ao conceito de multiplicação e velocidade ${ }^{12}$. O sobrevir/pervir aliam-se ao unitário/difuso, portanto andamento intensivo/regente e espacialidade extensiva/regida, e farão, até onde vemos,

\footnotetext{
${ }^{12}$ Zilberberg utiliza-se dos textos de Paul Valéry e Walter Benjamin para descrever a multiplicidade de meios, da música "gravada" para Valéry e a reprodutibilidade, sem alma, para Benjamin.
} 
a diferença entre a produção do destinador e a absorção do destinatário. Ubíquo por manter muitos destinatários atentos em muitos lugares ao mesmo tempo.

Com os levantamentos explanados até aqui referentes aos conceitos zilberberguianos sobre o ritmo, passamos a concordar: (i) a espera, e sua construção como expectativa, é a linha mestra da observação do ritmo. Todas as grandezas, direta ou indiretamente estão ligadas às paradas e seus reflexos temporais, assim como os reflexos de observação do próximo evento: “O ritmo engendra em nós uma disposição de alma que não se poderá apaziguar senão quando essa 'alguma coisa' sobrevier” (ZILBERBERG, 1965: 70); (ii) a construção em sistema executada por Zilberberg, diferente das oposições, permite a utilização de comutações mais clara, o que não ocorre nas teorias “algebristas” ou dedutivas (2010: 11); (iii) parece destacado o uso da análise pela leitura das subvalências de intensidade. Portanto, a tonicidade compõe um projeto enquanto o andamento compõe outro:

(...) quando a tonicidade prevalece, o objeto seria o complexo que reúne ritmo e profundidade; quando o andamento prevalece, o objeto seria o complexo que associa o acontecimento e a ubiquidade, o primeiro com vocação para satisfazer um sujeito da lentidão e o segundo, um sujeito da celeridade - (Zilberberg, 2010: 11).

A regência da tonicidade permite a escolha da atribuição relacionada ao ritmo permitindo uma análise, se observada a rede de relações complexas, pela linha do andamento ou da tonicidade. Portanto, e como exemplifica Zilberberg (2010), pode-se escolher uma dessas linhas para descrever um evento tensivo. Segundo o autor, esta base tensiva, do ritmo, contempla uma estrutura preventiva de ausências, uma vez que se previne a falta da profundidade na análise rítmica, e vice-versa, assim como a falta da ubiquidade no acontecimento e seu contrário.

\section{5 - A Predicação}

Muito citada, mas pouco argumentada, a predicação desenvolve importante papel na semiótica tensiva. Localizada tanto na construção sintáxica quanto na semântica, promove uma releitura de sentidos quando visualizada em um discurso. Passaremos por um breve convívio com a predicação, dentro do que concerne a este trabalho, depreendendo o tema constituído das observações de Zilberberg e de 
considerações avizinhadas aos conteúdos tensivos. Com isso, não pretendemos esgotar os argumentos diante do compêndio conceitual da predicação, mas referenciá-la dentro da Semiótica Tensiva, principalmente a de Zilberberg, e, com isso, argumentá-la diante do objeto desse estudo.

A predicação está vinculada ao conceito de recção, já citado neste capítulo, que entende um regente sobre regidos e, com isso, a composição, ou modificação, da significação. A construção do conceito da predicação pode ser observada nas normatizações gramaticais quando desenvolvem suas considerações sobre a centralidade do verbo na análise de uma frase. Para essa abordagem, passaremos brevemente pelo conceito de valência, também útil ao entendimento da semiótica. A valência remete aos estudos da lógica platônica e aristotélica que dividem a frase - a proposição, portanto o logos - em duas partes, sendo: o sujeito - suporte da predicação, ou ainda hypokeímenon - e o predicado - o comentário, ou rhema - resultando na observação de que um logos existe a partir de dois sinais: um nome e um verbo (NEVES, 2002: 103).

O logos consiste, pois, na atribuição de um rhêma a um ónoma, "nome”. Na doutrina
aristotélica, o logos se forma quando se diz algo (ação, lugar, qualidade) de uma
substância, isto é, de uma categoria nominal. Ficam na posição de sujeito tanto os
termos particulares, ou singulares (que denotam substância definida, geral). Na posição
de predicado só ficam os termos universais, que se referem a qualidade, estado, ações e
que, portanto, podem ser atribuídos aos termos nominais, quer definidos, quer
indefinidos. - (Neves, 2002: 104) - grifos originais.

Essa definição indica a organização da frase com o predicado portador dos termos universais, não particulares. Retirando o universal, distingue-se o centro da frase, sendo que o "restante” fora do centro é considerado como dependência com o centro: a partir de conexões. Tesnière propõe a centralidade do verbo como "nó" central da unidade estrutural da frase (apud NEVES, 2002: 105). Os demais elementos são vistos como "feixes" que dependem do verbo, fazendo da frase um conjunto de conexões construídas pelas relações de dependências e hierarquias:

Numa frase como Alfredo canta não existem apenas dois elementos, mas três: o primeiro á Alfredo , o segundo é canta e o terceiro é a conexão que une os dois primeiros elementos. O termo canta é o terceiro termo superior (regente) que tem subordinado a si (regido) o termo Alfredo. Esse termo regente constitui o nó central (..) e exprime um processo, um "pequeno drama” que envolve geralmente actantes, além de circunstantes. - (Neves, 2002: 105) - grifos originais.

Essa propriedade do verbo regente de actantes funciona como um núcleo de átomo que exerce atração sobre um determinado número de elétrons, ou seja, os actantes. O número de actantes dependentes dentro da circunscrição do verbo é 
chamado por Tesniére de valência. Portanto, existe uma valência do núcleo, verbo, que representa o conjunto de relações que "se estabelecem entre o verbo e seus actantes" (NEVES, 2002: 105): como constituintes indispensáveis para a compreensão do sentido. Existe, com isso, uma subordinação voltada ao centro, definindo-o como regente dos demais actantes, ou seja, dependências dos actantes para com seu núcleo.

O mesmo conceito é descrito por Zilberberg e Fontanille (2001) ao relacionarem a valência ao "número de lugares actanciais ligados a cada predicado na estrutura básica da frase” (TESNIÉRE apud FONTANILLE e ZILBERBERG, 2001: 15). Na Semiótica Tensiva, a valência refere-se às relações que unem um núcleo e seus periféricos, semelhante ao sistema desenvolvido na frase. Bem visto, o que parece relevante nas análises são as relações entre valência e suas subclasses, vide as estruturas tensivas, apontando para uma relação de dependência dos predicados e seus núcleos (FONTANILLE e ZILBERBERG, 2001: 15). Para a Semiótica Tensiva, a predicação produz subvalências correlacionadas que, em sua estrutura, apontarão para a variação da constante diretora da variação da variável (ZILBERBERG, 2012: 21). Ou seja, o mesmo núcleo regente sobre o actante regido, porém com hierarquias diante da distribuição das valências e subvalências.

O que parece o cerne da questão é a dependência ligada à recção, ou seja, a observação diante das valências regentes sobre as regidas. A recção aparece com essa finalidade na linguística: a “capacidade de reger outras palavras” (NEVES, 2002: 115). Por similaridade, a Semiótica Tensiva transformou essa palavra regida em valência extensiva, haja vista a regência da intensidade sobre a extensidade quando da construção do ritmo, entre outras grandezas promovidas pela rede de relações. Logo, na recção da extensidade, a intensidade subordinando a extensidade ao seu andamento, produz o que previa Zilberberg quando declarava que a tonicidade se torna mais espacializante, enquanto que o andamento se torna mais temporalizante (2010: 12). Podemos então concordar com a ideia de que, pela dependência mútua, as ações entre núcleo e o feixe de relações com o núcleo também serão dependentes mutuamente. Logo, caso se perceba alteração nos predicados, estes terão sido alterados pelo núcleo, e em nosso caso tensivo, altera-se o significado. A ação da predicação trata de revestir o núcleo de um significado, muitas vezes pelo caminho da alteração do predicado. Vendo de outra forma, e observando o que descreve Zilberberg quando define o predicado como o "grau zero" de uma definição, a ação da coexistência de predicações, exercida 
na tensividade, produzirá um sincretismo. Essa abordagem é formada pela coexistência entre estruturas, que geram uma função; entre conteúdos, que coexistindo geram uma tensividade; e de predicações, enfim, em sincretismo (2012: 22). As disjunções entre aspectos levariam aos termos aqui descrito:

Figura 19 - Quadro XIII - Predicação

\begin{tabular}{|l|l|l|}
\hline \multicolumn{1}{|c|}{ Operadores $\rightarrow$} & \multicolumn{1}{|c|}{ Conjunção } & \multicolumn{1}{c|}{ Disjunção } \\
Aspectos $\downarrow$ & \multicolumn{1}{|c|}{$\downarrow$} & $\downarrow$ \\
\hline Estrutura $\rightarrow$ & Função & Constante vs variável \\
\hline Conteúdo $\rightarrow$ & Tensividade & Intensidade vs extensidade \\
\hline Predicação $\rightarrow$ & Sincretismo & Definição (Simbolismo) \\
\hline
\end{tabular}

(Zilberberg, 2012: 23)

Observamos as conjunções, aqui descrita em níveis por Zilberberg, possíveis de análise. As disjunções não caberão na análise e não serão lidas dentro da Semiótica Tensiva. Dessa forma, analisamos o sincretismo resultante da conjunção de predicações, ou ainda, da sobreposição de predicados. Se observada pela Semiótica Tensiva, essa sobreposição se torna aparente quando descrita em um percurso que modalize o sujeito e seu relacionamento com os demais actantes do projeto. A modalização, ação do predicado que “sobretermina” outro predicado (FIORIN, 2000: 171-192), mostrará a relação entre actantes no percurso que, se somado aos aspectos desse processo, resolverá em predicado. Este parece ser o elemento fundamental do discurso, um logos, de só possível existência se observada a existência do predicado (BENVENISTE, 2005a: 137): o que determina a frase é o seu caráter distintivo de ser um predicado.

A "sintaxe" da proposição não é mais o código gramatical que lhe organiza a disposição. As entonações na sua variedade não têm valor universal e continuam a ser de apreciação subjetiva. Só o caráter predicativo da proposição pode, assim, valer como critério. - (Benveniste, 2005a: 137-8) - grifos originais.

A frase se difere dos demais níveis da classificação linguística, pois, em análise, a frase contém signos e ela mesma é um signo. Assim, a frase não pode ser dividida, mas relacionada a outras frases, outros logos, tornando o predicado, além de parte constitutiva da frase e ao mesmo tempo uma das unidades da frase, também formador do discurso. Encontramos aqui o chamado "grau zero de uma definição” como sendo o 
logos fundamental: a frase delineadora do discurso. "A frase, criação indefinida, variedade sem limite, é a própria vida da linguagem em ação. Concluímos que se deixa com a frase o domínio da língua como sistema de signos e se entra num outro universo, o da língua como instrumento de comunicação, cuja expressão é o discurso" (BENVENISTE, 2005a: 139). Entendemos, portanto, o predicado como elemento fundamental visível do discurso: o que alcança o destinatário, o que se comunica.

Estamos falando da observação de uma transformação de estados do sujeito, argumento e análise da semiótica, em que as disjunções e conjunções trarão significados passionais ao analista. Alguma tipologia de paixão pode ser encontrada pelas leituras de modalidades que, para sua dedução passional, observa a distância entre as ocorrências atualizadas e realizadas (FIORIN, 2000: 178). A atualização, dentro da disjunção entre sujeito e objeto (GREIMAS/COURTÉS, 1979: 35) só é apreendida quando observado o predicado que indica uma realização, ou seja, uma conjunção entre sujeito e objeto. Podemos concluir que o efeito predicador situa-se nessa passagem, nessa resolução do disjuntivo ao conjuntivo e, como parece a constante da predicação, diante de uma recção, mas, dessa vez, regida por outro predicado: sua sobreterminação. Esta é aparente ao analista que pressupõe sua formação, portanto, produto da soma da modalização e da aspectualização. Portanto, a transformação do sujeito é percebida como predicado modal e consagrada pela ação transitiva de um enunciado modal: ação que viabiliza uma sobreterminação regente, em ação rectiva, sobre enunciados descritivos (FIORIN, 2000: 179) ${ }^{13}$. Haverá uma “sobremodalização” (ibidem) dentro de um percurso que será percebido pelo analista como um ato predicador.

Temos, assim, as seguintes possibilidades modais: fazer ser é transformação narrativa de um estado em outro; ser do fazer são as condições requeridas para realização da ação; fazer fazer é o conjunto de modalidades factitivas que levam à ação; ser ser são as modalidades veridictórias que determinam a verdade, mentira, falsidade ou segredo de um estado. Sobre essas modalizações de base atuam sobremodalizações, quando o crer, o querer, o dever, o saber e o poder modalizam os enunciados elementares. (Fiorin, 2000: 179)

As "possibilidades modais" podem representar a situação do discurso, no entanto, interessa-nos as possibilidades modais de início e final do percurso analisado. A relação entre predicados, portanto a visão da aspectualização e da modulação de

\footnotetext{
${ }^{13}$ A diferença básica entre os enunciados modais e descritivos é a de que: os enunciados modais regem outro enunciado e; os enunciados descritivos contêm valores descritivos, isto é, o que descreve objetos consumíveis e entesouráveis, diferente dos valores modais, portanto, querer, poder, dever, saberser/fazer. GREIMAS; COURTÉS, 1979: pp. 112 e 483
} 
início e final, com seu núcleo, o significado abstraído de uma possibilidade modal, são vistos como valências, ricos à Semiótica Tensiva. Logo, as valências e as sub-valências mostrarão a "sobreposição" de predicados relacionados em posição ao núcleo da significação: como a postura dos conjuntos relacionais. Dessa forma, podemos estimar a visão dos predicados como relações de elementos pressupostos dentro de uma cadeia:

Figura 20- Gráfico Predicação

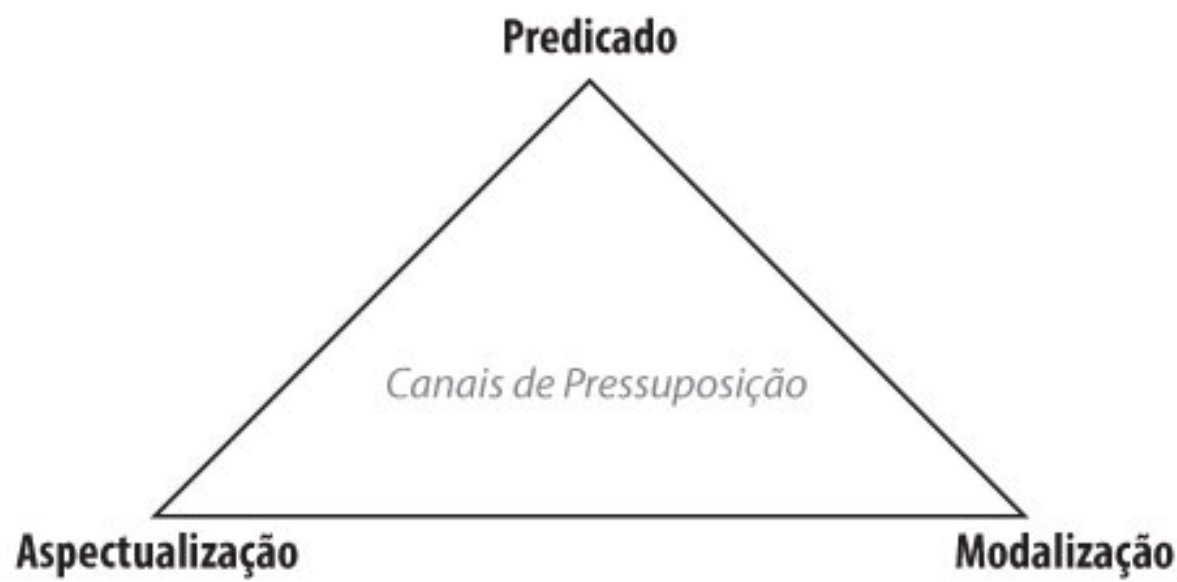

A predicação, parece-nos, surge como ato da sobreposição de predicados dentro de um percurso, transitivo e hierárquico pela recção do núcleo que determina a ação e sentido dedicado ao discurso. Assim, a predicação carrega em si os percursos da modalização assim como, presumimos, demostra os percursos dos actantes neles inseridos além de sintagmas relacionados e suas relações sintáxicas.

A posição da predicação parece ter relação com a posição da linguagem uma vez que o predicado carrega os termos referenciados aos estados, às qualidades e às ações, isto é, o que pode ser atribuído ao termo nominal. Ele demonstra a “cor” composicional do logos, o visível à percepção do observador. Retornando ao processo de visualização da predicação, o que podemos perceber é essa cor do evento analisado e pressupor seu núcleo. A cor pertence à periferia dos eventos e, por estar à volta do núcleo, parece de fato recobrir sua aparência. A aparência do que observamos, a cor vista à distância, contém actantes descrevendo um percurso reconhecível, objeto de nossa análise, e que, pelo deslocamento, recobre o núcleo constituído de aspectualizações e modalizações. As relações desse núcleo com a quantidade e qualidade dos actantes estabelecerão as valências e suas sub-valências. Assim, ao que parece, a variação no percurso dos actantes modalizados é que compõe a cor que percebemos do período analisado: resta- 
nos perceber o que existe em seu núcleo. Da mesma forma, e pelo princípio de pressuposição dedutiva e complementar, a alteração em um dos itens relacionais da modalização e da aspectualização farão mudar a cor do percebido, alterando a composição e reação dos actantes da periferia. Assim, a predicação se coloca como organizadora de uma esfera sincrética, que carrega os actantes modalizados, os arranjos de modalidades que evidenciam a análise das paixões e a condução dos tipos sintagmáticos relacionados formadores do discurso.

Parece-nos que a posição do predicado aqui argumentado diante da Semiótica Tensiva alia-se ao seu funcionamento frente ao enunciado, e não na gramática do enunciado, quando se utiliza de uma “concepção binária” (GREIMAS; COURTÉS, 1979: 346). A divisão pressuposta que liga o predicado ao sujeito, seu núcleo, ou ainda, ao descrito tema/rema pode também ser percebida por seu relacionamento entre sintagmas na construção do sentido do texto. Nesses relacionamentos podemos observar sistemas de hierarquias, recções, possíveis de conduzir o entendimento ou a argumentação do discurso e da distribuição de seus elementos em posições intensivas e extensivas, necessárias para a análise Tensiva.

\section{6 - A Retórica}

(...) o mito depende de uma ciência geral extensiva à linguística, que é a semiologia. Barthes $^{14}$

Pelos elementos elencados anteriormente como o “empilhamento”, a repetição, a adaptação, faz-se necessário um breve desenvolvimento ligado à retórica e esta ligada à Semiótica Tensiva. Zilberberg já havia encontrado essa ligação quando argumenta também sobre uma sobreposição de elementos no discurso (2011a) a qual passamos ao estudo. A exposição desse tema é importante para as futuras colocações ligadas ao meio de comunicação do cinema e da música, além da possibilidade da descoberta de novos elementos de análise tensiva.

Para Zilberberg, a Semiótica Tensiva engloba a retórica, não em sua totalidade, mas quando esta tangencia a construção de uma metáfora culturalmente "estável” e mantenedora de uma mitologia. Inicia explicando a possibilidade de encontrar, em uma

\footnotetext{
${ }^{14}$ BARTHES, Roland. Mitologias. Rio de Janeiro: Difel, 2009, p.210.
} 
leitura histórica ligada à arte, a leitura de um plano do conteúdo funcionando como plano de expressão, ou seja, uma “influência” advinda da observação das produções artísticas. Para isso, exemplifica Wölfflin e a passagem do Renascimento para o Barroco em que surge uma representação mais detalhada, com maior acuidade na produção, proporcionada pela evolução da técnica de pintura, do ovo ao óleo, e com isso, uma ressonância no plano do conteúdo.

As categorias semióticas, isto é, significantes, são semiósicas, no sentido de que sua vinculação a um plano da expressão não é de modo algum exclusiva: o aspecto no discurso plástico incidirá sobre a estética do "não -finito", da "melodia infinita" na música pós-romântica, sobre a vibração (Van Gogh) ou vigor (Bacon) da pincelada de acordo com os pintores etc. - (2011a: 199)

Ao que parece, o estilo atingiu uma “consistência” pela mudança técnica, no caso do Barroco: de uma lentidão na produção e de uma escola dedicada aos temas religiosos; será expoente de um plano do conteúdo inspirador. O estilo apontado por Zilberberg está relacionado à produção que, tanto nos exemplos pictóricos quanto nos literários, compreendemos, está vinculada à observação/aquisição de um público. São tentativas de aperfeiçoamento direcionados à uma eficiência: uma intensificação geradora.

Sendo de nosso estudo da natureza tensiva observar os limites, assim como alguns extralimites, voltemos ao posicionamento das ascendências e descendências nas cadeias de termos complexos.

Figura 21 - Quadro XIV - Extralimites
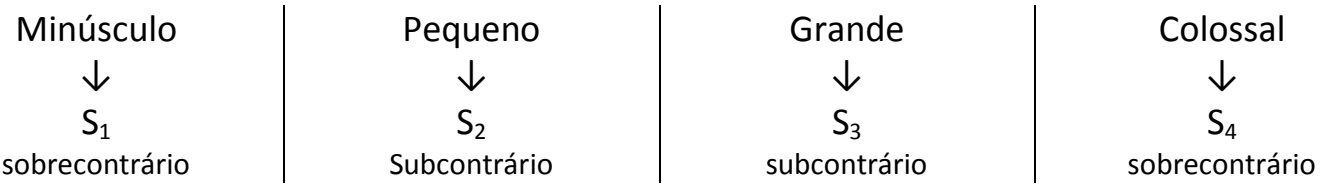

Zilberberg constrói a cadeia indicando os limites de máximos e mínimos e a movimentação entre termos. Sendo necessário, na operação analítica, articular a cadeia de forma descendente, teremos uma ação por diminuição da grandeza, o que ocasionará uma operação implicativa e doxal, esta que faz uma movimentação reconhecida e aceita; se articular a cadeia de forma ascendente, teremos uma ação por aumentação da pequenez, ocasionando a operação de concessão paradoxal, ou seja, a ação de movimentação surpreendente. Os movimentos serão de atenuação e minimização para a descendente e restabelecimento e recrudescimento para a ascendente: 
Figura 22 - Gráfico - Restabelecimento/Recrudecimento

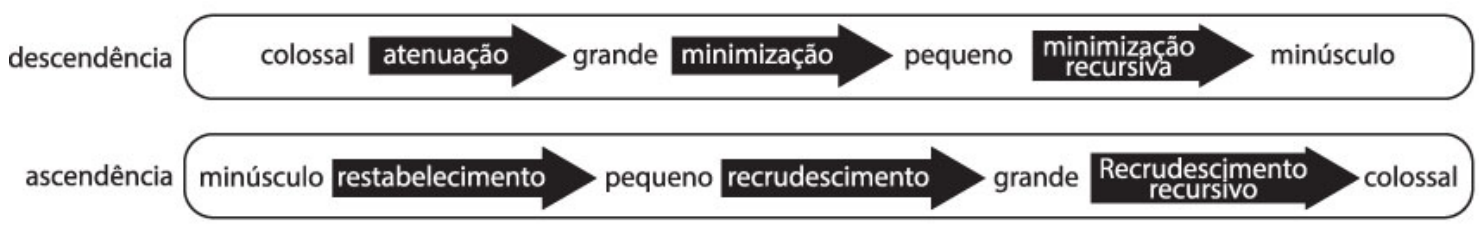

O movimento em direção ao limite da cadeia constrói uma recursividade do movimento, portanto suplementar, mas, segundo o autor, se observado o movimento concessivo de ascendência, temos o surpreendente, intensificação geradora, ao qual pode ser vinculada a figura da hipérbole. Esta observação aproxima a cadeia de termos, com seu movimento ascendente, de alguns fundamentos da Retórica. Logo, a retórica aparece na sintaxe intensiva, regente da extensiva que a tem como recção, e com seus termos apresentando superações contínuas.

A retórica escolhida por Zilberberg traz as referências de Aristóteles em seu terceiro livro sobre o tema. Apresenta uma "inauguração" do conceito de ponto de vista ao citar a percepção do fato semiótico como “mettre les faits devant les yeux" (apud ZILBERBERG, 2011a: 208) e, sobre isso, a construção de três referências: (i) a metáfora como figura argumentativa, pois esta apresenta as palavras estimulantes; (ii) a união da metáfora com a hipotipose sendo a metáfora como a variação da hipotipose, também apresentadoras das palavras estimulantes; (iii) a eficiência no uso dessas duas figuras. Essas três referências mostrarão o que Aristóteles chama de traço animado (idem: 209): "De maneira que a persuasão e sua sansão interpretativa ficam na dependência do sucesso da transposição, ou seja, da intensificação operada.” (ZILBERBERG, 2011a: 209). A metáfora exerce um papel importante na configuração da retórica de Aristóteles por ser ela que acessa a ação/eficiência do discurso. Zilberberg descreve o dispositivo desse acesso: 


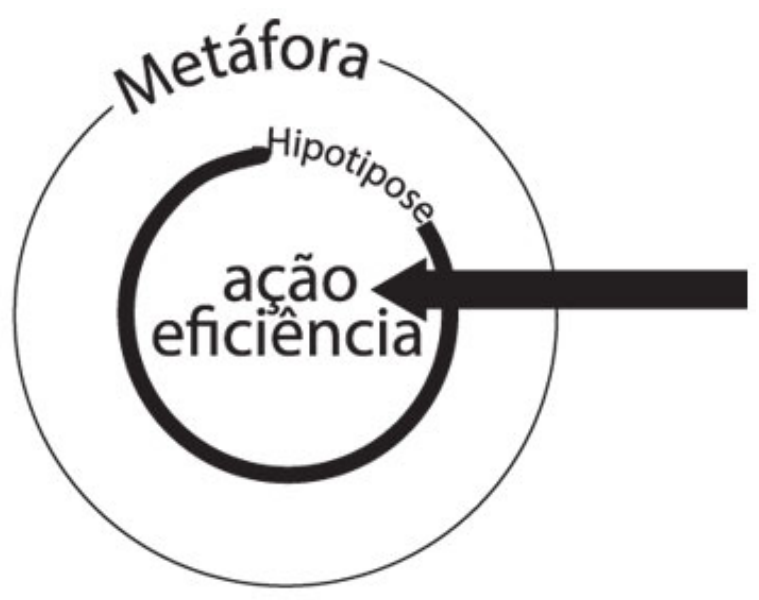

Ocorre a esperada intensificação do discurso se executadas as três referências de Aristóteles. A “produção” de uma eficiência pela metáfora/hipotipose será interpretada como elemento da economia linguística. A esta alusão, somaremos outra, agora dedicada ao filósofo Giambattista Vico (apud Zilberberg) que descreve: “Toda metáfora é um mito em pequena escala” (p.211). A tríade proposta por Zilberberg indica a língua como partilha do animado e do não-animado; a retórica como animação do nãoanimado; e o mito como garantia da superioridade do animado sobre o não-animado. Se aplicada, a tríade se torna uma motivadora permanente do discurso que: (i) na medida em que aumenta o animado assegura a repercussão subjetal do efeito retórico (ibidem); (ii) motivando o mito o transforma em uma metáfora em grande escala.

Zilberberg desenvolve as construções que ligam a retórica à semiótica tensiva, passando pelas categorias possíveis dessa leitura. Resta-nos, no estudo aqui desenvolvido, observar os três gêneros discursivos previstos por Aristóteles, portanto: o Elocutio, o Inventio e o Dipositio, que "prestam-se claramente à performance concessiva” (ZILBERBERG, 2011a: 224). Assim, a concessão retórica, atuante na descontinuidade do devir, une as estruturas da Semiótica Tensiva produzindo o que Zilberberg observa como estabilidade de estilo - o estilo que atinge uma consciência promovido pela indicação de uma apreensão ao destinatário. Passaremos ao processo de construções metafóricas destinadas a tentativas de mitologias de um lado, e de produções rítmicas hiperbólicas de outro. Atendemos assim ao conteúdo da semiótica tensiva de observar os eventos sob a ótica de uma produção eficiente e econômica direcionada a um público. 
Capítulo 2:

A escuta e a composição musical para cinema 


\section{2 - A escuta e a composição musical para cinema}

O cinema pode ser descrito como o meio de comunicação de massa que adere um grande número de textos com o propósito de fundi-los até a emissão de um texto único. O percurso que leva até essa unicidade foi marcado por empirismos que parecem ter se estabilizado elevando o cinema como meio de comunicação de massa. Nas tentativas que buscam a atenção de seus públicos, talvez a maior delas seja a da composição musical, tornando-a o elemento de maior preponderância no desenvolvimento narrativo do filme e, se bem observada, é também o componente unificador do meio: “(...) uma música de fosso que, ao escapar à noção de tempo e de espaço reais, arrastam as imagens num mesmo fluxo” (CHION, 2011: 43). Assim, com o intuito de desenvolver a argumentação do potencial discursivo do cinema, torna-se necessária a observação de um breve percurso histórico da música no cinema. Torna-se também necessária a exposição de conceitos ligados à tecnologia e à mudança da escuta, promovida pelas gravações e transmissões à distância. Chegaremos ao estudo dos meios de comunicação e à teoria da informação, como parâmetros dessa programação midiática do cinema e da música.

Do percurso percorrido pelo meio até o século XX, observa-se a construção de uma forma ideal de enunciação, desenvolvida pela construção programada de expectativas. Podemos observar essa programação tanto na música separada do cinema, como nela justaposta ao filme. Dessa forma, abordaremos a teoria analítica de Leonard Meyer, estudioso norte-americano e defensor dos sistemas culturalmente condicionados de expectativas na música. Meyer apresenta um aparente sistema de crenças construídas por enunciatários aculturados que mantem a comunicação/composição ativa e linear. No decorrer dessas apresentações, emergem importantes paralelos entre as teorias de comunicação e das teorias analíticas com os fundamentos da Semiótica Tensiva, principalmente no que adere às argumentações sobre a retórica. 


\section{1 - Apontamentos históricos sobre a composição para cinema}

Ao que parece, o cinema sempre foi sonoro, e mais do que sonoro, esse meio quase sempre foi musicado. De sua invenção até as primeiras estabilidades comerciais, o cinema nunca foi literalmente "mudo", como a história o determina. O cinema nasce mudo em conceito, mas carrega em si ideias sonoras e musicais, passando por ajustes técnicos até sua estabilidade sincrônica. A mudez do cinema não se referia apenas às falas, mas a não sonoridade daquele meio visual e, como descreve Aumont, definia uma divisão estética cunhada após a descoberta das falas sincronizadas aos seus falantes, tirando daí seu epiteto, "como uma enfermidade” de afasia (AUMONT, 2012: 202). Após a sincronia, as informações musicais não pararam de ter influência na narrativa fílmica. Conceitos e padrões se estabeleceram até os tempos mais remotos, promovendo ainda hoje transformações técnicas, além de experimentos dignos de observação. Toda a construção técnica e conceitual da música no cinema estimulou a construção de uma persuasão, a que passaremos a tratar adiante, passando por um breve levantamento histórico do meio para compreender o som e a música no filme, assim como a compreensão da importância dedicada à música neste meio.

\subsection{1 - Como nasceu "mudo"}

O paradoxo e o charme do cinema mudo residem na importância atribuída aos fenômenos sonoros. Chion $^{15}$

O cinema parece ter nascido e imediatamente preenchido uma necessidade contida em uma população. Da produção inventiva dos irmãos Lumière ${ }^{16}$ aos primeiros filmes de Georges Méliès não se passara um ano e, pouco depois, tomava a atenção da elite parisiense. As exibições, ainda sem um padrão de furação da cinta fílmica, nem de tamanhos ou maquinários, eram feitas em feiras temáticas e cafés, disputando a atenção com outros entretenimentos da época, como o vaudeville, operetas, teatros, entre outros. Na mesma época, o rádio se desenvolvia, e teria um futuro também brilhante, mas com outra conduta. O cinema mostrava seu desenvolvimento tanto em conceitos

\footnotetext{
${ }^{15}$ Michel Chion (2003) p. 13

${ }^{16}$ Existe uma confusão de informações sobre a invenção do cinematógrafo visto que atribui-se a Léon Bouly a primeira patente em 1892 a qual misteriosamente se perdeu dando espaço para a patente dos irmão Lumière em 1895.
} 
quanto em técnicas, aliás, que ali começariam e nunca mais se desligariam esses dois eixos relacionados aos meios de comunicação. Com essa configuração, ou seja, em locais destinados à elite e considerados como uma moda curiosa, se portou o primeiro ciclo desse novo entretenimento. O desenvolvimento maior veio em seguida com a saturação rápida desse circuito e a frutificação comercial, mas dessa vez, para o grande público, a massa (ROSENFELD, 2013: 67-70). Mas um fator pode ter retirado os olhos da elite parisiense dessa moda, o incêndio de 1897 durante uma sessão no Bazar de la Charité, em Paris, que matou mais de 120 pessoas daquela mesma elite, deixando a febril moda com ares negativos, a ponto de manter recusas de financiamento pelos bancos da época (idem).

Em pouco tempo o cinema teria uma nova face, com filme de maior duração, entre 12 a 15 minutos nos primeiros anos da virada do século, projetores menos ruidosos e novos conceitos de imagens. A principal observação sobre esse período se refere ao fazer sonoro do filme mudo, ou seja, à compreensão de que a produção deveria ter som, mesmo que sugestionado (CHION, 2003: 12-5). São muitos os movimentos gestuais de atores em cena que comprovam essa observação de Chion (idem). Parece existir uma tentativa de comparar-se, ou até atrair para si, outras formas públicas de entretenimento, ou seja, as operetas, os teatros de variedades, os dramas. Se passarmos pelo repertório deixado por Méliès, veremos a tentativa de entreter seu público com um tipo de tradução fílmica de seus shows de mágica e ilusões. Chion aponta o primeiro filme com o que ele chama de enredo, isto é, um filme com alguma narrativa, diferente do que ocorria na época, como exemplo dessa tentativa de sugestionar o som. Trata-se do The great train Robbery, exibido em 1903, de Edwin S. Porter: o filme traz, em sua temática de western, efeitos de cores, adicionadas manualmente nas películas, postas sobre as fumaças de explosões e tiros de revolver. Sem som, a tentativa aqui apontada por Chion é a de mostrar o impacto que essas ações desenvolvem: os ruídos, sonoplastia, som sincronizado, mesmo sem tê-lo. Cria assim, um fantasma sensorial, na verdade, mais um de uma época que tenta mesclar sugestões sonoras, a exemplo da literatura, da pintura, da poesia, entre outras misturas artísticas (idem). No cinema, as sugestões sonoras são claras: torna os sons, e até a música, subentendida, mesmo que entre os reais ruídos da sala de projeção, mas com as referências associadas ao universo do espectador. Se relacionarmos essa ação a outro meio da mesma época, encontraremos o rádio que propaga peças de teatro e novelas, tentando a todo custo criar sugestões de imagens sem tê-las. A interferência de ações de cada meio é válida, sem 
que se crie a divisão de conceitos pelo público. Das muitas tentativas de ordenar a sensação sonora do cinema, passando por sonoplastas diante da tela ou locutores, chegou-se ao instrumentista, só ou acompanhado, para uma nova construção.

Logo depois da Primeira Guerra Mundial, surgem muitos teatros destinados à reprodução de filmes na Europa e EUA, já promovendo filmes musicados. Na maioria dos casos dispunham de pianos ou órgãos e, dependendo da localização ou preferencia do público, pequenos conjuntos e até pequenas orquestras. É importante imaginar a execução musical durante as sessões em que, por evocarem conceitos sonoros e musicais, reafirmavam as questões sonoras. Os músicos eram a referência musical das cenas, fossem essas românticas, agitadas, escuras ou repletas de referências conhecidas da época: o músico encaixava pedaços de composições famosas, muitas vezes retiradas das operetas, óperas ou até reduções das composições orquestrais de Beethoven ou Mozart. Valia qualquer coisa para "adaptar” músicas às imagens. O mais curioso era a necessidade de musicar eventos filmados sem uma referência direta com a narrativa, como o vento, águas, chuva ou pessoas correndo. Chion dá o exemplo da sugestão sonora de uma guirlanda sonora para evocar o som do vento, execução comum também em peças de teatros (idem). Cresce a atração musical e, com ela, surge a necessidade de composições para cinema, mesmo que mudo ainda. Duas formas de composição ficaram consagradas: os fake-books e as indicações musicais por períodos. Os fake-books eram livros com peças para piano onde cada peça estava relacionada a um humor (DAVIS, 2010: 6-10). Assim, de acordo com a cena reproduzida, o pianista executava a peça indicada. Alguns produtores de filmes já traziam uma pequena "bula" indicando a sequência dos humores das cenas, permitindo ao executor um acompanhamento musical mais próximo às ideias do diretor do filme. Com relativo sucesso durante o cinema mudo, os fake-books pareciam tentar, por um lado, fixar as experiências áudiovisuais do público, por outro, reinventava as possibilidades de entretenimento e atenção deixadas pelos vaudevilles e óperas ainda existentes. Ficaram conhecidas edições como Kinibibliothek, ou Kinothek como popularmente foram chamados, de Giuseppe Becce; Motion Picture Moods de Erno Rapée e The Sam Fox Moving Pictures Music Volumes de J. S. Zamecnik. 


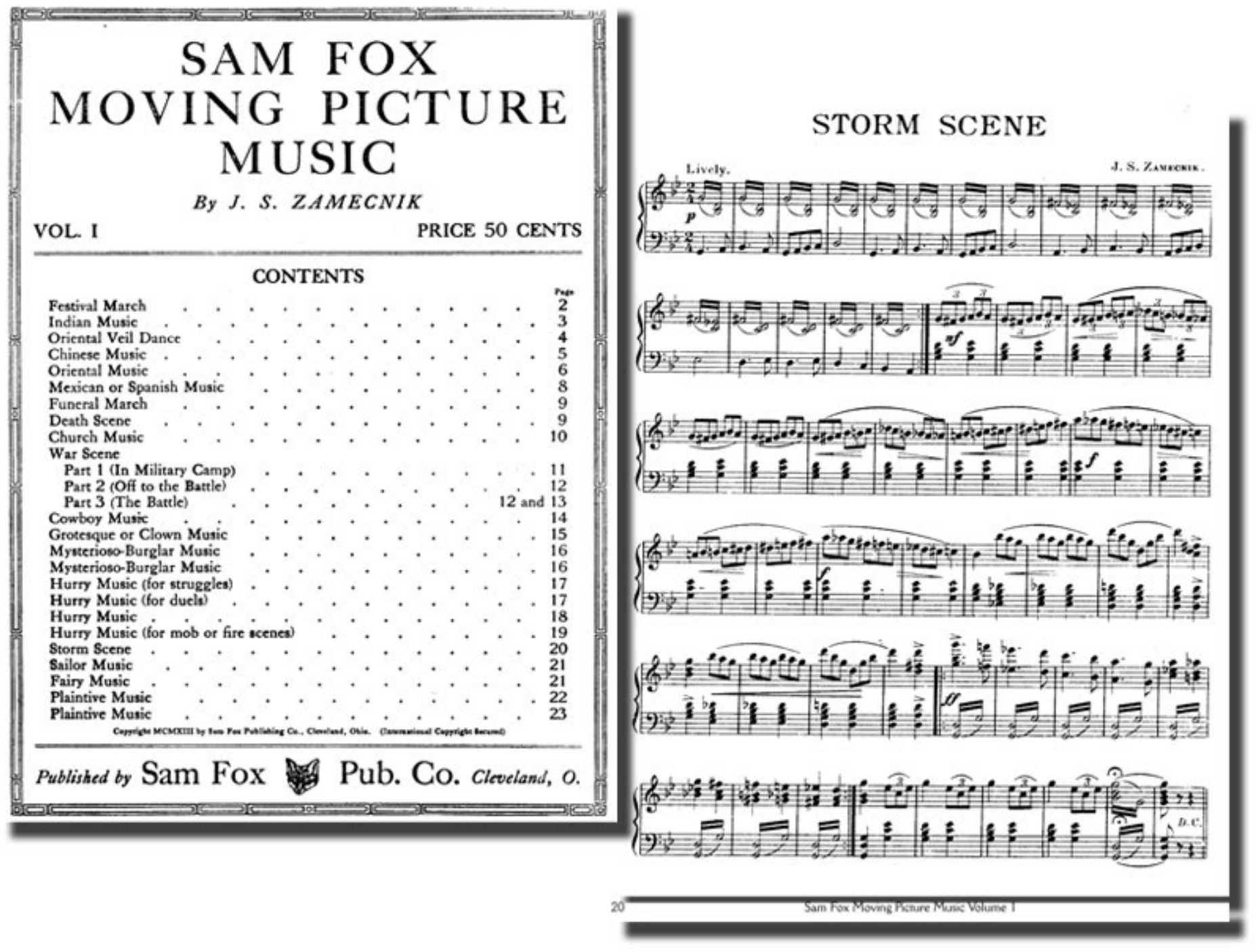

As indicações musicais tinham a preocupação da sincronização das cenas com a música. Mesmo sem conter composições originais, indicavam composições conhecidas que deveriam ser executadas em uma marcação de tempo descrita. O sistema dependia de uma prévia análise do filme para a roteirização musical posterior. A desvantagem, pelo menos na época, foi a exclusividade que cada publicação necessitava uma vez que teria sido organizada para um filme apenas, coisa comum em dias atuais, mas distante das ideias da época. Ainda nesse período, algumas composições foram feitas para acompanhamento de órgão, pequenos conjuntos ou pequenas orquestras, caso o teatro comportasse. Estas composições já eram direcionadas a um único filme, com marcação de tempos sincronizados e indicações de dinâmicas e eram editadas pelas próprias produtoras ou distribuidoras do filme, assim, com o intuito de unificar as percepções musicais diante das cenas (idem). Os procedimentos vão adiante quando promovem-se 
tentativas de trocas de significados entre cineastas e músicos com novos sistemas. A compilação musical de Ernst Luz indica, além de um excerto musical a ser sincronizado com o filme, a duração, a dinâmica e uma cor. Esta cor teria relação com um capítulo de sua própria publicação, o segundo capítulo intitulado The Symphonic Color Guide, contido em seu Motion Picture Synchrony, de 1925. A publicação teria ainda partituras de referência, tipos de classificações e tipos de repertórios. 
Figura 25 - Partitura para cinema - Ernst Luz

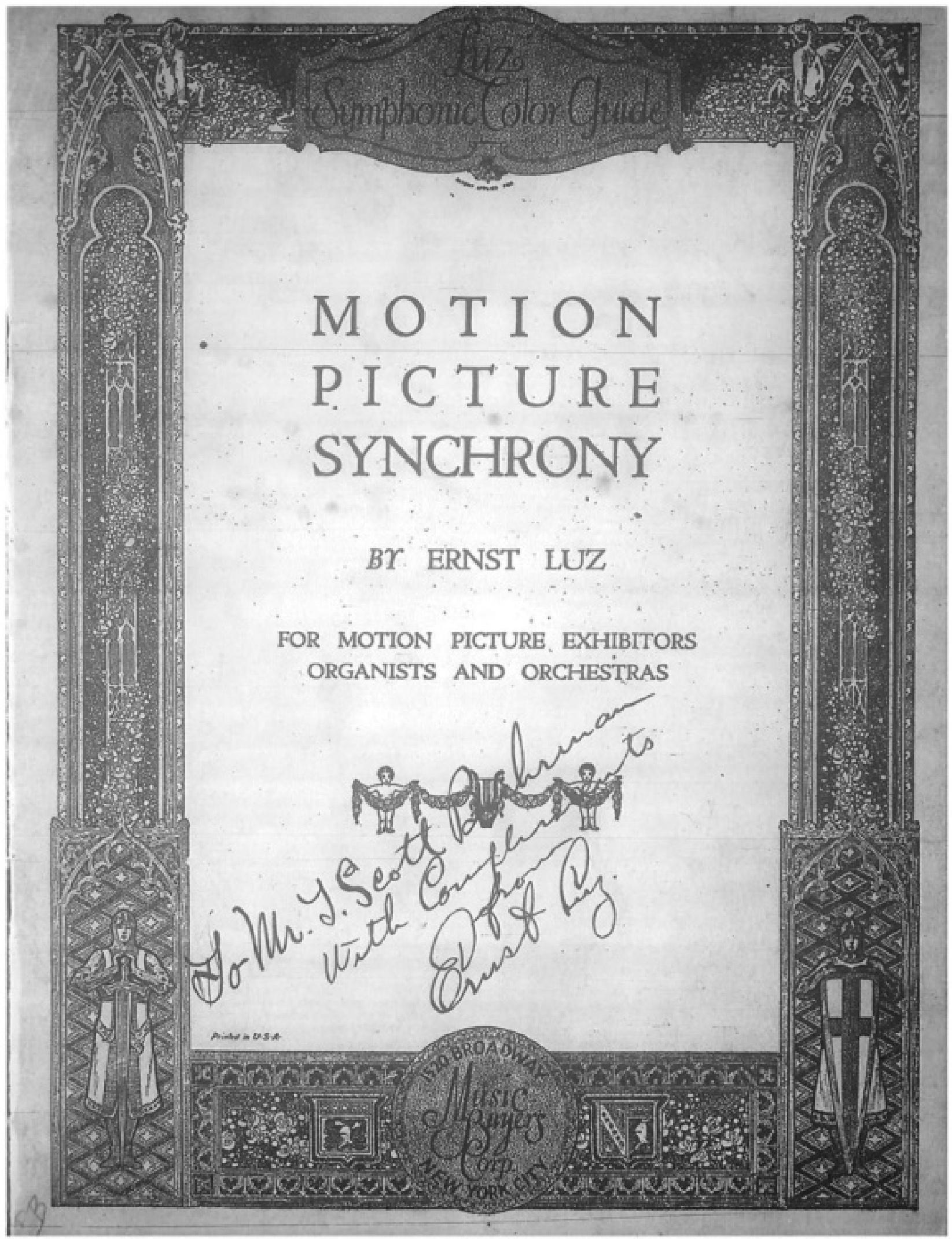




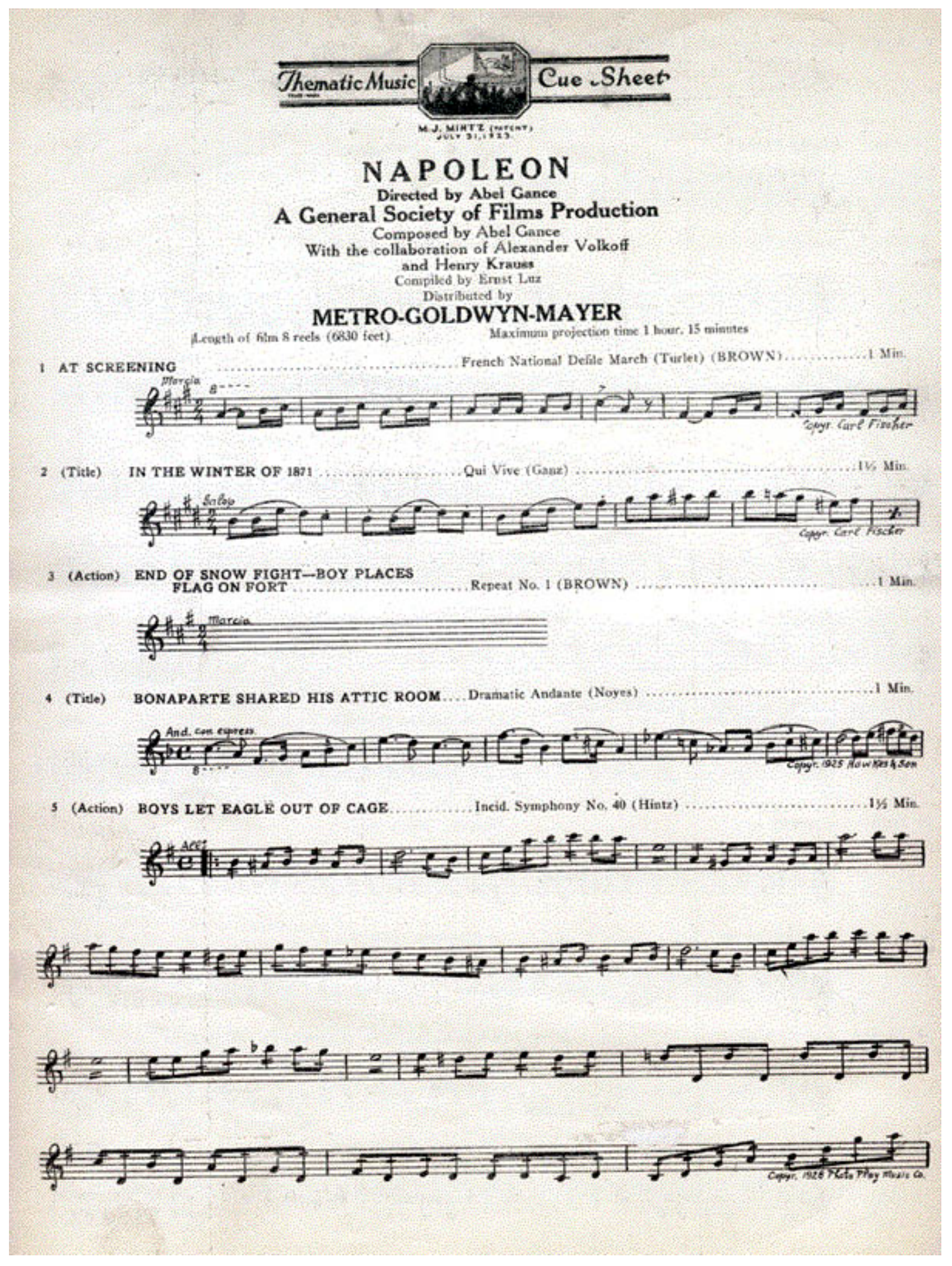


Dessa forma, mesmo que os músicos e os teatros fossem diferentes, havia uma tentativa de adequar música à narrativa produzindo um texto único: o texto fílmico/musical. O cinema nasce aparentemente mudo, mas parece não querer manter sua “afasia”. A produção musical se impõe necessária diante de uma concorrência de entretenimentos, só fazendo progredir em conceitos e tecnologias. O próximo e tortuoso passo dará lugar ao produto fílmico/sonoro que, embora também aparentemente completo, passará por fases de amadurecimento.

\subsection{2 - Como se descobriu sonoro}

O som do cinema tem um início experimental e cheio de adaptações até chegar em uma primeira estabilidade técnica. A aparição do som não declarou a fala como muitos imaginam, mas a música, que resgatou mais ainda a experiência das formas de entretenimentos teatrais da época. A fala sincronizada ainda dependeria de um logo caminho técnico até o seu uso mais aperfeiçoado. Com isso, o que se descobre no cinema é uma lenta mudança de paradigmas ligados à narrativa do filme, uma vez que a música reafirmaria o seu papel como construtora de sentidos no filme.

Encontramos um consenso na maioria dos pesquisadores que indicam o filme The Jazz Singer, de 1927, como o primeiro filme sonoro, embora outros testes anteriores a este pudessem ser também considerados (CHION, 2003: 34-9). As melhoras tecnológicas de outros meios, como do rádio e os sistemas de autofalantes, contribuíram para a introdução do som no cinema, mas as maiores contribuições para a presença da música do cinema, assim como o ruído e posteriormente a fala, foram as tentativas de melhorias no sistema de sincronização. O filme The Jazz Singer tem mais tempo musicado do que falado (ibidem) e as poucas falas parecem compor uma introdução à próxima canção ou apresentação de dança musicada: ou seja, ainda parece organizar uma apresentação teatral. Essa ideia de "terceira parede” do palco permaneceu por muito tempo na atmosfera do cinema, talvez pela preocupação comercial de vinculá-lo a outro entretenimento de sucesso. Preocupação evidente diante da música por perceberem fracassos contumazes em tentativas de filmes que, embora sonoros, não 
continham músicas (ROSENFELD, 2013: 142). Parece-nos que, dividindo os ambientes de evolução tecnológica e esta ligada a necessidades conceituais e comerciais, os EUA tiveram uma ideia diferente da Europa quando evoluíram seus equipamentos. A Europa, Itália e França, pensavam o cinema como desdobramento da ópera e das operetas, enquanto os EUA pensavam-no como desdobramento do vaudeville. Em análise, nenhum dos dois pensava o cinema como uma nova arte ou novo meio de comunicação.

Assim, só com o advento dos projetores com velocidade variada é que os filmes passaram a ser produzidos com diálogos, uma vez que poderiam variar a velocidade das imagens para que ficassem sincronizadas ao disco de acetato que emitia o som. A técnica não foi introduzida de forma massificada e, mesmo quando ocorreu, dependia da experiência de técnicos em cada teatro. Em meados dos anos 1932 é que a indústria do cinema desenvolve um sistema que alinhava o som na mesma película em que se encontram as imagens e, com isso, estabiliza-se o sincronismo. A novidade notoriamente divulgada, mais do que a novidade anterior em que finalmente haveria um cinema sincronizado e não apenas sonorizado; levantou criticas dos puristas que preferiam o estilo anterior. Trouxe também desemprego para muitos músicos que deixaram de ser parte da atração do filme. Um caso interessante pode ser citado para demonstrar a extensão da utilização de “anexos" à projeção e sua derrocada impulsionada pelo novo cinema sincronizado: é o caso dos benshi japoneses. Os benshi eram, no início, tradutores dos textos que o cinema expunha quando da utilização das falas, ou seja, traduziam para a plateia o que os personagens estavam conversando. Logo em seguida passaram a explicadores das narrativas e foram até a execução de dublagem de falas em algumas cenas que, por trabalharem nos palcos dos cinemas e decorarem as falas, as reproduziam no momento sincronizado. Alguns benshi disputavam atrações com o filme e chegaram a ser tão importantes quanto os atores dos filmes, como é o caso de Heigo Kurosawa, irmão do conhecido diretor japonês Akira Kurosawa, que se matou ao ver o cinema sincronizado e ver também sua decadência. É claro que esta é apenas uma das faces do processo de evolução tecnológica que, passadas as críticas e desempregos, alterou toda uma conduta comercial e perceptiva diante do som e, principalmente, da música.

A bricolagem entre som e filme mostraria novas ideias construtoras de também novas ações da arte e do entretenimento. Em primeiro lugar, podemos observar a definição de fotogramas, os frames, sendo 24 fotogramas por segundo definidos pelo 
som, e não pela imagem: essa definição partiu da necessidade de estabilizar o som gravado (CHION, 2003: 36-7). Além da definição do comprimento da fita, o sincronismo se apresentou útil na representação verdadeira da fala, agora sincronizada ao gesto do ator e não mais indicada por ações extravagantes ou quadros de textos. Direciona-se agora a uma focalização na voz e nos textos falados, o que faz emergir uma quantidade suficiente de teorias sobre o vococentrico e o verbocentrico do cinema (idem), posteriormente também atribuído à televisão. Ainda sobre as construções advindas do sincronismo, a música se desenvolve com novos aspectos e fará uma revolução conceitual.

\section{$\underline{2.1 .3}$ - Como se organizou musicado}

O cinema sonoro, e ao que parece muito musicado, se espalha lentamente. Em datas similares temos grandes obras faladas e musicadas e, ao mesmo tempo, produzidas sem som, embora coexistam também as produções que preferem a ausência de falas, produzindo um cinema eminentemente mudo, mas com composições musicais próprias, como é o caso dos filmes de Charlie Chaplin a partir de 1930: Luzes da Cidade, de 1931 já contem música composta, pelo próprio Chaplin, e exibida em sincronia. A coexistência de produções com características diferentes se deve à lenta aplicação da completa sincronia. Podemos dizer que a sincronia mudou a forma de produção do filme que, quanto mais testava seus limites, mais ultrapassava novas fronteiras de percepção. O primeiro estilo a testar tais limites fora o estilo dos desenhos animados (CHION, 2003: 37-42). Com suas sinfonias audiovisuais, os desenhos animados das décadas de 1930 até meados de 1940 construíram uma verdadeira enciclopédia de ações ligadas a músicas, ruídos retirados de instrumentos, paródias, brincadeiras sonoras, entre outros adereços utilizados na sucessão das produções fílmicas. Deste legado, a relação fílmico/musical que devemos observar é a indicação da sensação ao expectador: uma escala decrescente para alguém, ou alguma coisa, que cai de uma escada, ou ainda, a mesma escala descendente para alguém que se decepciona; assunto de nosso interesse a ser abordado no próximo capítulo. Outro fato observado relacionado ao sincronismo é a construção de um ritmo geral das cenas (idem). Esta rítmica será explorada também ao seu limite por promover uma constante atenção da audiência, fato este indicado por alguns autores como promotor do que chamamos de 
popular, ou seja, destinado a cada vez mais públicos (CHION, 2003; BAZIN, 2014; ROSENFELD, 2013). Isso nos leva a uma dupla percepção sobre a música no cinema sincronizado: (i) a música funciona como uma "resignificadora" dos gestos e ações visuais: os elementos experimentados pelos desenhos animados têm ressonância no universo de efeitos em filmes que passam a reordená-los com sucesso; e (ii) a música funciona como uma construtora de ritmos musicais e fílmicos, não apenas das cenas, mas do filme todo (CHION, 2003; 2011).

Ainda que estas mudanças façam parte da evolução de um meio, de seu comércio, de suas composições, produções e pessoas, a música ainda é tratada como a orquestra no fosso. Desde as primeiras ações musicais diante das telas até o sincronismo, a música ligada ao filme tenta parecer-se com a música executada nas orquestras quando exibidas juntamente com apresentações teatrais. A ópera pode nos dar a melhor posição sobre essa música de fosso: composta e organizada como texto único, a ópera nasce como representação de narrativas em dramas cantados e representados por cantores que atuavam as situações, as lutas e as mortes no palco. A orquestra não deveria aparecer, salvo em raras exceções, e a esta foi destinado o espaço entre o palco e plateia chamado de fosso. Com o "amadurecimento" do sincronismo, a questão da invisibilidade da emissão musical muda e passamos a observar variações dessa emissão musical dentro da cena ou fora da cena, ou seja, na tela ou no fosso.

Mais adiante, e com a estabilidade do sincronismo, observamos a mudança de estilos decorrente do período pós-segunda-guerra-mundial. A aparição de novas experiências musicais, tanto em estilos como na apresentação da música: procura-se um novo estilo uma vez que as músicas entendidas como étnicas, como as marchas, as valsas, boleros, rondós, usados até então, parecem representar outras nações (CHION, 2003); a música se apresenta agora como conceito ligado ao personagem ou à situação e não mais como pontuação de conflitos. As escolhas, principalmente no cinema norte americano, pairam sobre o jazz, o atonal, a música lapidada que mantêm um contínuo quase psíquico sobre as sequências. Com essas mudanças, a música deixa de ser o "pano de fundo" das cenas para se tornar mais um elemento da narrativa. A evolução do meio, e consequentemente da utilização da música, terá sua próxima ruptura na criação do sistema Dolby, em meados dos anos 1970, que estimulará composições mais detalhadas, uniões com ruídos e localização espacial do som na sala de cinema. A nova tecnologia permitiria edições objetivando um “design sonoro”, atualmente estabilizado 
como técnica de produções cinematográficas, também deixando estável a posição da música no discurso fílmico.

\section{2 - Conceitos da música de cinema}

A composição e a interpretação da música devem levar ao ânimo do público o destrutivo e o horrendo existente em um efeito musical. Adorno / Eisler $^{17}$

Se considerarmos os desenvolvimentos técnicos e tecnológicos ligados ao som do cinema, estes vistos desde a possibilidade de sincronia de som e imagens no início da década de 1930 até a distribuição sonora em canais diferenciados em estéreo ou multidirecionais das modernas salas de cinema, perceberemos um aperfeiçoamento mais do que sonoro, mas também comercial. A conduta do meio de comunicação prevê a constante preocupação com a captação e manutenção de públicos. No cinema isso não é diferente e, assim como em outros meios no decorrer do século XX, essa comunicação em direção ao público aprimora-se produzindo efeitos cada vez mais cativantes e, consequentemente, mais lucrativos.

\section{$\underline{2.2 .1 \text { - A escuta no cinema }}$}

É possível perceber o caminho percorrido pela composição musical para cinema se observarmos pelo menos duas vias de ação dessa música: o percurso tecnológico, dos equipamentos de gravação e reprodução, e os conceitos musicais ligados ao filme, já abordados neste capítulo. Mas talvez o elemento de maior mudança nos conceitos composicionais para cinema ainda esteja em desenvolvimento: a escuta. Em uma abordagem crítica ligada a composições musicais contemporâneas, principalmente à música concreta, Pierre Schaeffer descreve uma mudança na escuta dos ouvintes constantemente influenciada pelas alterações dos meios de fixação e reprodução. A conclusão do compositor e crítico é a de que domesticamos nossa escuta de acordo com o desenvolvimento comercial e técnico (2003).

De fato, não é difícil perceber tais alterações, tanto na música como nas imagens fílmicas, que estão ligadas ao processo de reprodução. Para Schaeffer, tanto o rádio como o cinema, aos quais ele chama de “arte-relés”, são a tentativa distante de uma

\footnotetext{
${ }^{17}$ ADORNO, Theodor W.; EISLER, Hanns. El cine y la música. Madri: Fundamentos, 1981 - p. 41-2
} 
reprodução natural: aceitá-la será uma perversão da escuta (idem). São muitos pontos de discordância do som original, ainda mais se vistos à época deste texto em 1938, como atrasos, dinâmicas e sem percepção biauricular, considerando o rádio dos anos 1930 a 40. Esses pontos levam Schaeffer a especular o rádio como instrumento musical, por comportar-se como objeto musical (2003: 80), e o cinema, aquele dos anos 30 e 40, como um desarticulado sistema de som e imagem. A utilidade das abordagens de Schaeffer para esta pesquisa repousa na articulação que fará em seguida que, ao que parece, combina com o cinema em sincronia entre sons e imagens: o conceito de acusmática. O termo é retirado do nome dado a um dos discípulos de Pitágoras que escutava suas lições escondido de trás de uma cortina. Apenas ouvindo e sem vê-lo ${ }^{18}$ (idem), aumentava seu estado de concentração por não se dispersar com questões visuais. Buscando a essência da música, Schaeffer desenvolve sobre o mesmo sistema uma significação musical sem perceber o objeto sonoro (MENEZES, 2009: 151-2). Esta nova escuta, a acusmática, difere da escuta tradicional, ou natural, uma vez que passa pelo transporte elétrico e, principalmente, manipulado. Este potencial manipulado eleva a escuta ao limite da percepção: não existem sons extras, a atenção fica concentrada. Nesse momento, se o rádio é um instrumento, o cinema é um instrumento bricolado. Descreve:

\begin{abstract}
"O cinema surpreende a centelha de um olhar, as alterações de uma fisionomia, fornece uma imagem surpreendente do objeto. Determinado poeta, conhecido somente por impressos, se faz ouvir e sua poesia é uma revelação. Os silêncios falam; o menor ruído, uma folha de papel amassado, a batida de uma porta, e nossos ouvidos parecem escutar pela primeira vez. Sim, as coisas agora têm uma linguagem, como a própria semelhança das palavras o diz: imagem, que é linguagem para o olho, bruitage (sonoplastia), que é linguagem para o ouvido.” - grifos originais - SCHAEFFER, 2010, p. 96
\end{abstract}

A linguagem encontrada por Schaeffer se refere ao sistema recém-desenvolvido para as arte-relés e se desdobra dos anos 1940 até os anos 1960. Seu maior esforço metodológico sobre este tema data de 1966 com o Traitè des objets musicaux quando desenvolve outra importante contribuição: as funções da escuta. Apresenta quatro funções: escutar, ouvir, entender e compreender ${ }^{19}$ que, embora não relacionadas diretamente ao ato físico, desenvolvem aspectos relacionado à percepção do ouvinte (SCHAEFFER, 2003: 61-66). Resumidamente, e sem tentar explicar toda a abordagem de Shaeffer para as escutas, além da constatação de que seria descuidado diante do tema

\footnotetext{
${ }^{18}$ Do Grego, akousmatikós, e, ón: predisposto ou habituado a escutar; ákousma, atos: o que se ouve. HOUAISS, Antônio. Dicionário Houaiss da Língua Portuguesa. Rio de Janeiro, Ed. Objetiva, 2001.

${ }^{19}$ Écouter, ouïr, entendre, compreendre.
} 
desse trabalho, a função do escutar (i) está ligada ao reconhecimento da fonte sonora, à emissão do som físico e palpável. Mesmo que todas as funções estejam ligadas ao apreender do ouvinte, portanto de caráter subjetivo, o escutar se relaciona ao intersubjetivo, pois depende de uma construção social e cultural para o reconhecimento de tal fonte. Já a função do ouvir (ii) é ligada à constante recepção do som, passiva e sem reconhecimento direto: toda massa sonora sem distinção específica do som. Por ser individualizada e sem necessidade de referências anteriores, essa função é subjetiva. A função do entender (iii) é ligada à intencionalidade do som, o que é possível selecionar qualitativamente imputando "intensões" pessoais no som. Por tratar do interesse particular da escuta do ouvinte, esta função também é de caráter subjetivo. A função do compreender (iv) relaciona-se à busca do significado do som, de seu sentido diante de um sistema de valores musicais, de época, de estilos. Nesta função emergem os sons como conteúdos, assim como suas comparações e limites. A duas primeiras funções, o escutar e o ouvir, são de natureza concreta, ou seja, existem impulsionadas por uma fonte física. As outras duas funções, o entender e o compreender, são de natureza abstrata, uma vez que participam de uma seleção derivada de processos do intelecto (SCHAEFFER, 2003: 61-66). A divisão proposta por Shaeffer propõe um mecanismo de comunicação do som que passa pelas funções, portanto: inicia-se por um acontecimento de interesse na escuta, passando para o ouvir físico, a percepção bruta da “condição de não estar surdo”, depois, ao entender pelo também interesse e experiência do sujeito e, finalmente, ao compreender o que escuta balizado pelas referências pessoais. O quadro se desenvolve assim:

Figura 27 - Percurso da escuta

\begin{tabular}{l|l|l} 
& Intersubjetivo & Subjetivo \\
\hline Concreto & escutar & ouvir \\
\hline Abstrato & compreender & entender
\end{tabular}

O que se inicia com um acontecimento sonoro encontra repouso na compreensão da qualidade deste acontecimento, indicando ao ouvinte o significado e uma possível linguagem sonora (idem: 66). No caso do sujeito da escuta não identificar o som, ou seja, caso o acontecimento não encontre repouso na compreensão abstrata, passa o sujeito ao estado de deduções. Shaeffer indica ser esta uma condição instantânea e da natureza do ser desde nossas percepções mais primitivas (idem: 67). A nosso ver, a 
cadeia sugerida por Shaeffer, que passa da escuta concreta à compreensão abstrata, pode ser a geradora da condição de expectativa desenvolvida pela ausência da compreensão sonora. Shaeffer desenvolverá seu estudo propondo um objeto sonoro e, posteriormente, uma escuta reduzida, isto é, aquela direcionada ao escutar e ao compreender intersubjetivos, argumentos estes retirado da redução fenomenológica de Husserl. Essa centralização do sujeito e afastamento da escuta condicionada leva ao reconhecimento de uma escuta pura, investigadora da textura, massa e velocidade do som (CHION, 2011: 28), de grande influência em análises musicológicas do século XX, mas de pouca aderência ao estudo da música de cinema. No que nos compete, deixaremos para futuros estudos a situação da escuta reduzida e abordaremos as escutas concreto/abstrata, subjetiva/intersubjetivas. Essa divisão na teoria permitirá explorar a condição do sujeito da expectativa sonora e sua construção a partir da música de fosso, ou seja, a que não é vista diretamente, porém, percebida.

A mudança na escuta, e sua perversão, nos leva ao encontro de uma escuta específica no cinema que, se indicado o período a partir do sincronismo de som e imagens, percebe a construção polifônica e essencial do som (CARRASCO, 2003). A música passa a ser concebida juntamente com as outras três essências sonoras do filme: as falas e os ruídos. No entanto, falas e ruídos ainda podem ser considerados categorias visíveis ou dentro de uma percepção visual ou espacial, já a música compõe um discurso acusmático: aquela que ouvimos mas não percebemos a causa (CHION, 2011; SHAEFFER, 2003). A música acusmática do cinema será a formadora, de um lado, da expectativa necessária à manutenção de atenção de seus variados públicos, e de outro, da ressignificação musical, advinda de uma escuta específica que a própria acusmática promove: uma escuta intersubjetiva geradora de conteúdos.

A questão da acusmática indica ainda outras questões ligadas ao cinema: seu uso confere um entendimento direto ou indireto, isto é, o entendimento de sua causa/fonte. Percebemos o uso da música podendo soar como uma orquestra no fosso, acima citada, ou como de fato visualizada na cena. A visualização, ou não, da fonte musical, e sonora em geral, desenvolve um importante fator conceitual no cinema e, também um extenso campo de discussões sobre o tratamento dessa abordagem. Se considerarmos a fonte musical não visualizada, portanto promotora da expectativa como descreve Shaeffer, como acusmática, devemos aceita-la como não acusmática o simples evento de sua visualidade na cena do filme. Esse ponto se torna importante por ser previsto, pela teoria 
de Shaeffer, que a música se torna acusmática desde que não seja visualizado o seu executor, físico e ao vivo. Distanciaremos desse ponto e trataremos a visualização “mecânica” como suficiente para o entendimento da fonte musical (CHION, 2011: 61), ou seja, se o emissor da música se tornar visível pela tela do cinema será considerado como não-acusmático. Sendo dessa escolha, passamos ao inesgotável percurso de exceções no universo cinematográfico, sendo de improvável redução em exemplos ocorridos em filmes. Imaginemos a cena de um filme com uma música de fosso que, no decorrer da cena, a orquestra que executa a música ouvida aparece na cena: passamos de uma situação acusmática para uma não-acusmática. Resolve-se, em teoria, tratar a questão como visualizado ou acusmático (idem: 62), ou ainda, como dentro ou fora do campo fílmico. Chion propõe uma leitura mais interessante sobre a música visualizada ou não, indicando a necessidade de observação sobre o que pertence à narrativa, indicando uma música diegética ou não-diegética ${ }^{20}$ (indem: 62-3). Desenvolve, além do fora do campo, as noções de in e off, compondo um circuito chamado tri-círculo:

Figura 28 - Gráfico Áreas de escuta I

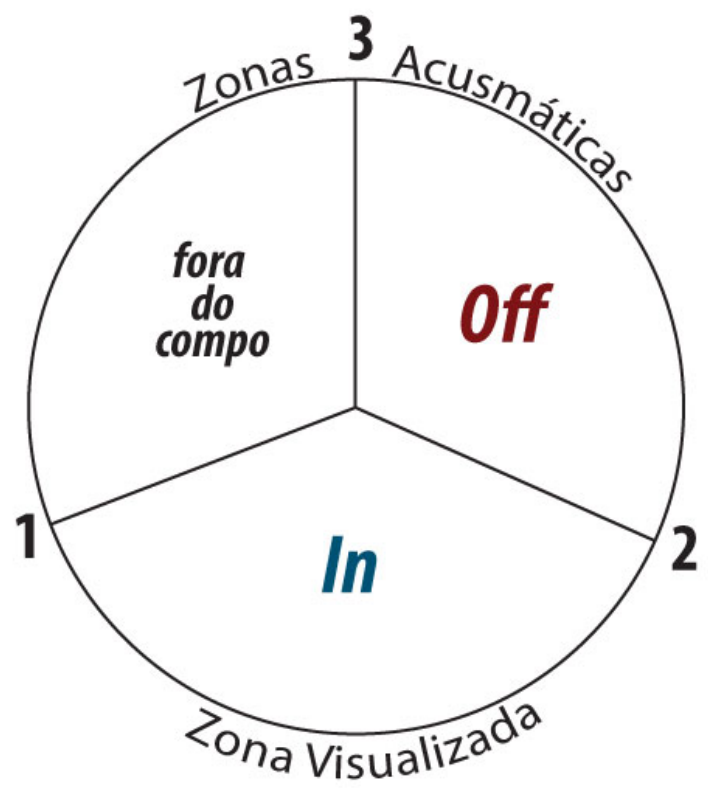

Trata a zona acusmática contendo o som fora do campo e o som off, diferenciados pelo que existe ou não na narrativa. Portanto, som fora do campo trata da música que entra e sai da cena, sendo possível na narrativa: uma música que acompanha

\footnotetext{
${ }^{20}$ Chion trata eminentemente do som geral, separando as incidências entre música e os ruídos da cena, ou ainda, das vozes. Aqui, encontram-se as referências ligadas à música já distintas dos demais pontos abordados por Chion na tentativa de tornar o tema mais brando.
} 
a cena e depois mostra-se emitida por um rádio, por exemplo. O som off trata de uma música que fisicamente não pode fazer parte daquela cena: uma música orquestral em um deserto, por exemplo. O som in trata dos sons visíveis e dentro da cena. Chion acena para um possível sintagma audiovisual apontando as fronteiras possíveis entre campos: fronteira 1: entre in e fdc; fronteira 2: entre in e off; fronteira 3: entre fdc e off (idem: 63). Com essa análise podemos observar as transições musicais que ocorrem dentro e fora das cenas.

Chion amplia a construção do tri-círculo tratando dos sons ambientes às cenas, assim como os sons internos, visualizados ou não, e as vozes de atores ou locutores. A tentativa é abordar o máximo de relações entre campos espaciais a fim de cobrir os variados casos sonoros produzidos pelo cinema, suas variações de posição na narrativa e de espaços gerais.

Figura 29- Gráfico Áreas de escuta II

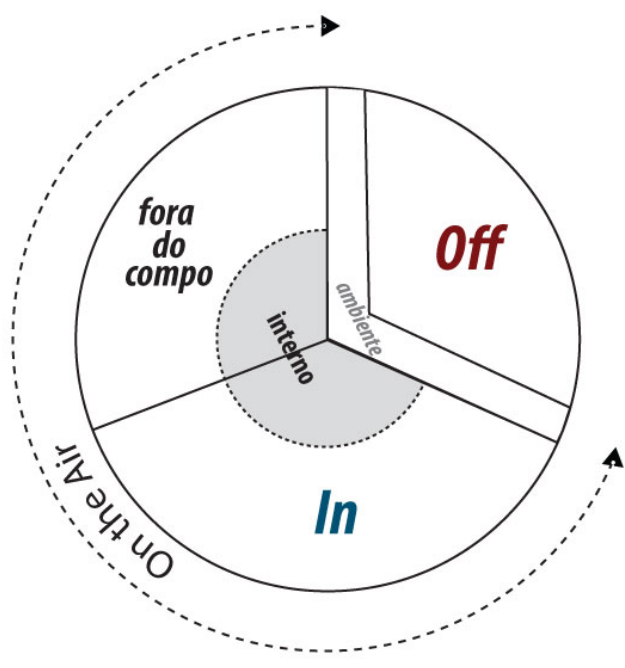

A tentativa traz boa articulação ao estudo e resolve uma grande quantidade de análises relacionadas ao som geral do cinema. Em nosso caso, o gráfico anterior já será suficiente para a análise musical, visto da não necessidade das abordagens complexas relacionadas aos demais sons do cinema. O que nos interessa observar é a relação musico/espacial localizada dentro ou fora da cena e a percepção do expectador relacionado esse espaço, in/off, aos efeitos de expectativa e espacialidade do filme. Observado por Chion, o cinema se caracteriza por conter um lugar definido para a imagem e por não haver a possibilidade de contensão espacial do som (idem: 57-8). Nesse caso, os sons diretos das cenas, ou seja, as falas localizadas em seus “atores”, os 
sons físicos ou ambientes, podem marcar uma localização pelo sincronismo acionado à cena, mas se considerada uma música de fosso, acusmática e em off, não haverá possibilidade de contê-la: ela existirá em todo o espaço físico e conceitual da cena. Constroem-se supercampos (ibidem) de percepção capazes de extrapolar os limites da tela dimensionada do cinema. Por fim, o desenvolvimento técnico do som, a mudança no conceito cultural de escuta nos ouvintes, principalmente do cinema, apontado por Shaeffer e a acusmática são formadores de: (i) uma preferência da música como elemento construtor da narrativa sonora de um filme, muitas vezes acima dos ruídos e falas; (ii) a formação do estado de atenção desse ouvinte, sua expectativa e, (iii) a expansão do contato fílmico pelo expectador.

Isso nos posiciona diante de outro relevante desenvolvimento na observação sobre a música no cinema: a formação da expectativa pela musical através da composição. Esse tema parte da análise musical desenvolvida por Leonard Meyer e seu sistema culturalmente condicionado de expectativas que, em meados dos anos de 1950, demonstra como a composição musical pode conter elementos formadores de expectativa direcionados aos seus públicos. Essa composição, nos parece, está inserida nas músicas compostas para cinema do século XX.

\subsection{3 - A expectativa na composição}

"[...] todo sistema de comunicação de massa necessita de certo nível de doutrina relativamente ao fim que persegue" Abraham Moles $^{21}$

Como vimos, o desenvolvimento da música no cinema passou por notáveis experimentos e processos que, ao que parece, não repousaram seus modelos de construção, necessariamente atualizados em decorrência de sua identidade comercial. Além dessa constante progressão, a composição musical para cinema ainda atravessou as relações de convivência com seus públicos que, como descrito acima, ajustou seus procedimentos de gravação e propagação a partir de uma adaptação natural da escuta. Nesse momento, o que nos parece pertinente observar é a composição musical no século XX diante de sua relação com o público e, em um desdobramento perceptível, seu desenvolvimento ligado ao público do cinema. Essa abordagem tenta mostrar que existe

\footnotetext{
${ }^{21}$ MOLES, Abraham. Sociodinâmica da cultura; tradução: Mauro W. Barbosa de Almeida. São Paulo: Perspectiva, 1974.
} 
um sistema culturalmente condicionado de expectativas percebido por compositores e produtores, de música e de cinema, interessados em direcionar as composições aos afetos de seus expectadores.

São muitas as teorias e críticas ligadas à comunicação midiática e seus efeitos, positivos ou negativos, analisando locais, populações, expectadores, ou simplesmente, pessoas receptoras e passivas da informação veiculada. Sem tentar desenvolver explanações sobre os meios de comunicação e sua relação com seus derivados e associados, podemos, com o foco na abordagem do conteúdo desse trabalho, selecionar um importante período dentre as tantas teorias da comunicação de massa: a teoria da informação. Essa teoria pode nos auxiliar localizando a utilização da expectativa na composição musical, assim como no cinema, e, como veremos, alinha-se ao pensamento de Shaeffer e a composição musical que chega aos nossos ouvidos através de meios de divulgação e não pela execução direta, tornando-a invisível e subvertida, conforme descrito por Shaeffer em À la recherche d'une musique concrète de 1952. A teoria da informação foi acolhida por Meyer em Emotion and Meaning in Music ${ }^{22}$, de 1956, que desenvolve o conceito do qual define o significado musical como sendo a variação entre a frustração ou satisfação diante de expectativas musicais (BENT; DRABKIN, 1987: 59). A teoria da informação foi desenvolvida por Claude Shannon ${ }^{23}$ em sua publicação intitulada Teoria matemática da comunicação, de 1948, depois atualizada por Abraham Moles em Teoria da informação e percepção estética, de 1958, de onde se extrai o conceito de uma transmissão ideal de mensagem em um esquema geral de comunicação (WOLF, 2008: 108-9). Concluem que a informação tem maior ou menor eficiência quando aborda a variação de expectativas, ou seja, menor expectativa gera maior informação. A informação é transmitida e da mesma forma recebida, como uma escolha de mensagens dentre um conjunto de mensagens possíveis. Com frequência, pode-se observar uma coleção de mensagens com maior absorção pelo meio do que outras, o que fará a escolha do emissor ser mais ou menos objetiva (BENT; DRABKIN, 1987: 57-8). Assim, o efeito de baixa e alta expectativa contida em uma enunciação gera alta ou baixa recepção e a não confirmação de itens prováveis gera expectativa. A teoria prevê ainda a possibilidade da utilização dos ruídos, existentes entre a fonte e o destinatário, no percurso da informação:

\footnotetext{
${ }^{22}$ METER, Leonard B. Emotion and meaning in music. Chicago: University of Chicago Press 1956.

${ }^{23}(1916-2001)$
} 
Figura 30 - Percurso da informação

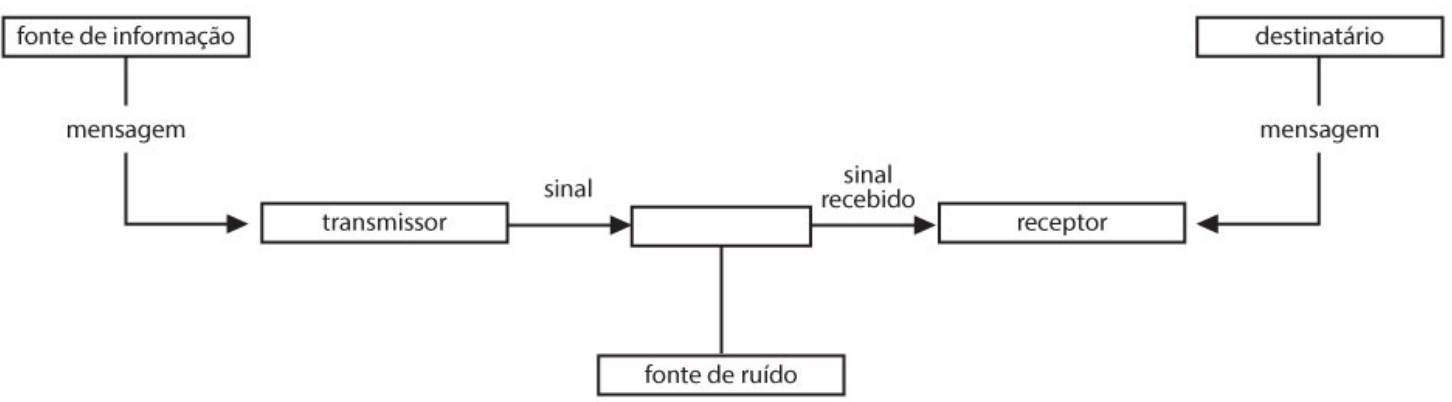

A interferência do ruído atrapalha a máxima transmissão e sua economia de tempo/energia, esta prevista na origem da teoria matemática. Essa perturbação, o ruído, foi captada pelos teóricos dos meios de comunicação como sendo uma variante possível de adaptar aperfeiçoamentos na transmissão (WOLF, 2008: 108-9). O que ocorre é uma estrutura que alinha os ruídos de acordo com a necessidade e, com isso, produz códigos que permitem uma comunicação eficiente:

“[...] se obtêm, mediante uma codificação perfeita, altos valores de fidelidade do canal.
Trata-se, portanto, de conseguir determinar o modo mais econômico, veloz e seguro de
codificar uma mensagem, sem que a presença do ruído tornasse sua transmissão
problemática." - (WOLF, 2008: 111)

A vontade de estabelecer uma comunicação aperfeiçoada tende a sucessivas adaptações do código até sua eficácia no canal, utilizando as mesmas variáveis concernentes ao código, desde a fonte até o receptor (MOLES, 69: 78-9). Isso produz um estilo, uma forma de execução de mensagens que visam a eficiência do discurso: “o código é um sistema de regras que atribui a determinados sinais um determinado valor” (ECO, 1972: 11 apud WOLF, 2008:111). Valor ou significado, segundo Eco, é atribuído o termo valor por considerar a possibilidade da comunicação via códigos entre duas máquinas, conhecida por relação homeostásica (ibidem). A questão códica terá uma importante variação conceitual nas análises de Jakobson na década seguinte, encontrando na comunicação, entre pessoas, a necessidade de unir a teoria da informação ao desenvolvimento dos estudos linguísticos (WOLF, 2008: 116). Jakobson apontará a não relação matemática da comunicação, mas a relação entre traços distintivos (JAKOBSON, 2011: 73). Isto é, ao invés de aplicar a eficiência de uma informação pela quantidade de decisões binárias, com ou sem algum tipo de ruído, que permitem ao destinatário reconstruir o valor, passa a considerar os conjuntos 
reconhecíveis. Os traços distintivos são agrupados em feixes, fonemas, e encadeados em sequências, dando ao processo de comunicação oral linguística um caráter granular e, ao mesmo tempo, de possibilidades de significados, e não mais valores, incalculáveis. Logo, aponta as unidades elementares de informação como invariantes relacionais, portanto, direcionadas à língua falada, sem conjuntos finitos de elementos discretos como a língua escrita, mas reconhecendo códigos pelos invariantes contidos em grupos (idem: 74-5). Os traços distintivos fazem oposição aos traços redundantes, tomados como ramos da retórica linguística, previstos também na teoria da informação como não informação, ou seja, uma confirmação da expectativa. Os traços redundantes podem ser classificados como formadores de estruturas de repetição, comum na arte e nas composições musicais, fílmicas, etc: “O caráter distintivo e a redundância, longe de serem postulados arbitrários do investigador, estão objetivamente presentes e delimitados na linguagem.” (idem: 76). Jakobson atenua a especificidade da teoria da informação, observando a propagação da informação segundo um código comum e uniforme e dentro de relações funcionais entre emissão e recepção (WOLF, 2008: 117).

Era importante, para a análise musical de Meyer, observar o desenvolvimento da teoria da informação. Porém, podemos ainda indicar duas outras influências para a formação de sua teoria: [i] a primeira é a publicação de Processo temático na música de Rudolf Réti, em 1951, autor que utiliza os conceitos de Schoenberg sobre composição romântica e estabelece uma redução temática, células musicais, reconhecíveis, extraídas dos motivos musicais (BENT; DRABKIN, 1987: 55-6). Em Fundamentos da composição musical, de 1937, Arnold Schoenberg demostra como “reduzir” uma obra musical aos seus reconhecíveis motivos, frases, antecedentes e consequentes, períodos, sentenças e seções. Estabelece uma forma classificatória que, segundo Schoenberg, permite a compreensão do todo através das unidades (ibidem), assim como a manutenção da coerência de uma obra composta e já enriquecida de conceitos e entendimentos: a coerência mantém-se pelo relacionamento ordenado das unidades. Estabelece a ideia de uma composição orgânica que ordena as variações das unidades rítmicas, harmônicas, intervalares, melódicas, etc., e a estas unidades adicionam-se notas auxiliares (ibidem). Réti desenvolve uma expansão das unidades a partir de seu reconhecimento, chegando a indicar um percurso da célula ao seu padrão temático: forma de desenvolvimento de toda a composição a partir de um suposto início (BENT; DRABKIN, 1987: 60). [ii] A segunda influência para a análise de Meyer pode ser 
atribuída à publicação Language and music: parallels and divergences de George $\mathrm{P}$. Springer, em 1956, dedicada à obra de Roman Jakobson. Springer utiliza o desdobramento da teoria da informação praticado por Jakobson, somado ao pensamento de Gustav Becking e os paralelos entre fonologia e musicologia nos épicos populares Servo-Croatas. Becking coordenou o Congresso Internacional das Ciências Fonéticas, de 1932 em Amsterdã, e baseou-se nas distinções fonológicas de Trubetzkoy. A tentativa de criar uma tipologia para os padrões musicais folclóricos de Becking influenciará Springer na observação da repetição: a identidade e a diferença como oposição binária, assim como o conceito de variantes e invariantes de Jakobson (idem: 59). Estas ocorrências científicas estariam em recentes ações quando da construção dos conceitos de Meyer que veremos a seguir.

\section{3 - Meyer e a expectativa}

Em Emotion and Meaning in Music, de 1956, Leonard Meyer apresenta uma proposta de análise musical levando-se em conta a apreensão do sentido gerado pela música como sendo o resultado de frustrações ou satisfações diante das expectativas do ouvinte. Em foco estava o desenvolvimento da teoria da informação aliada ao pensamento da linguística de Jakobson compondo um sistema cultural condicionado de expectativas. Meyer questiona as análises musicais praticadas até a sua época e as classifica como hedonistas, pelo resgate de gostos pessoais e sem fundamentos; como atomistas, pela redução até a menor unidade objetivando o entendimento do todo; e como universalistas, por tratar a música, principalmente ocidental europeia como a correta e de valor. Contra essas correntes apresenta uma ótica sobre sua organização comunicacional baseada na emoção, ou seja, uma música dirigida ao seu púbico encarregando-se de dispor elementos de comunicação entre enunciador e enunciatário:

"O ouvinte traz para o ato de percepção crenças definitivas do poder afetivo da música. Mesmo antes do primeiro som ser ouvido, essas crenças ativam disposições para responder de forma emocional." Tradução livre, (MEYER, 1956: 11)

Meyer reutilizará os conceitos de traços distintivos e traços redundantes da teoria da informação reavaliada pelo linguista Jakobson indicando o efeito de resposta emocional do ouvinte diante de eventos musicais: a resposta emocional presa ou inibida 
evocará o afeto (idem: 22). A incerteza, a falta de clareza, os contrastes entre outras figuras musicais de certo conflito são avaliados como geradores de apreensão e ansiedade, ou seja, paixões. Com isso, os acontecimentos sucessivos da composição musical, intercalados entre certezas e incertezas diante de seus ouvintes, terão uma relação conativa com o repertório do destinatário:

Uma vez que essas sucessões de sons comuns a uma cultura, um estilo, ou uma obra particular, assim determinada, se a sucessão habitual é apresentada e concluída sem demora, pode-se supor que, uma vez que nenhuma tendência teria sido inibida, o ouvinte não responderia de forma afetiva. Se, por outro lado, a sucessão de som não consegue seguir o seu curso habitual, ou tratando-se de obscuridade ou ambiguidade, então pode presumir-se que as tendências do ouvinte estariam inibidas ou estranhas e que as tensões que surgem neste processo seriam experimentadas como afeto, desde que não fossem racionalizadas como experiência intelectual consciente. - Tradução livre, (MEYER, 1956: 32)

A variação de estados patêmicos do ouvinte estaria relacionada à apresentação de acidentes ou confirmações dos repertórios. Meyer aponta para uma familiaridade do ouvinte com o estilo, com o repertório e, principalmente, com a norma de execução desse repertório. Caso a familiaridade não seja direta, haverá um ajuste por parte do ouvinte, condição esta em que se propõe um suspense musical, o inesperado, que surpreende e em seguida passa por uma acomodação em um sistema geral de crenças (idem: 30). Aqui se observa a formação da expectativa musical, induzida pela cadeia de acontecimentos que Meyer chama de síntese mental, ou seja, a cada evento de suspense ocorre (i) uma espera do próximo acontecimento com a suspensão do julgamento e a crença da normalização do evento; (ii) na ausência da normalização ocorrerá a apreensão e (iii) a descoberta de um erro ou de uma solução, de repetição ou mudança de evento, trará repouso ao ouvinte. O despertar do afeto pelos eventos de suspense são a forma de condução da composição musical (idem, 31). Visto dessa forma, essa composição se torna auto referenciada, apresentando a possibilidade de uma condução de eventos extra-musicais (idem: 35). Estes eventos nos permitem identificar os significados em cada fase da composição: “um evento musical (seja ele um tom, uma frase ou uma seção inteira) tem significado porque nos faz perceber outro evento musical" (ibidem). Se identificados pelo ouvinte, e participando do processo de composição, cada relação de similaridade entre eventos é chamada de relação de conformidade: uma identificação dos elementos discretos relacionais do conjunto composto (idem: 44), uma morfologia estrutural da composição musical. A escuta implica em tendências expectantes e culturalmente estabelecidas, ou de formações 
códicas em processo durante a audição. Meyer divide a apreensão extra-musical em três tipos de significações:

(i) que indicam significados hipotéticos: aqueles apreendidos durante o ato de expectativa, ou seja, o compreendido dentro de um estilo e suas variáveis:

"Desde que esteja previsto é um produto das relações de probabilidade que existem como parte do estilo e, uma vez que estas relações de probabilidade envolvem sempre a possibilidade de consequências alternativas, um dado estímulo invariavelmente dá origem a vários significados hipotéticos alternativos.” - Tradução livre, (MEYER, 1956: 37)

Pode-se observar a estabilidade do estilo, e dos códigos dentro do estilo, entendendo a variação de confirmação de expectativas, ocasionando novas etapas de significações e, dessa sucessão, constroem-se referências: “atualizada como um evento de música concreta” (ibidem).

(ii) que indicam significados evidentes: atribuídos a gestos antecedentes evidenciados pelo consequente, ou seja, quando a relação antecedente/consequente ${ }^{24}$ é percebida. Essa constatação pode levar ao reconhecimento de uma cadeia, ou cadência, podendo ser casual ou não. Meyer exemplifica com uma sequência onde um estímulo [S] leva ao consequente [C], que também é um estímulo, e indica/realiza mais consequentes:

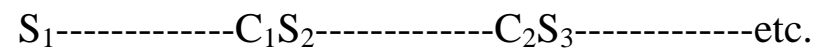

Uma vez que se apresenta como auto-referenciada pela própria demarcação códica, a relação antecedente/consequente pode se expandir em procedimentos variados:

“(...) o significado evidente decorre não apenas da relação entre $S_{1}$ e $C_{1}$, mas também fora das relações entre $S_{1}$ em todos os consequentes subsequentes, na medida em que estes são considerados para a emissão de $S_{1}$. Também é importante perceber que o movimento $S_{1}$------- $C_{1}$ pode se tornar um gesto que dá origem a consequentes previstas e reais e, portanto, torna-se um termo ou gesto em outro nível de relações da tríade." Tradução livre, (MEYER, 1956: 38).

Assim, os significados hipotético e evidente apresentam-se na composição formando uma arquitetura organizada da obra. O significado evidente é “colorido e

\footnotetext{
${ }^{24}$ Figura tradicional da música ocidental, refere-se ao par de frases, ou eventos musicais, compostos com a finalidade de expor a segunda frase como repetição ou afirmação da primeira frase. Segundo o dicionário Grove de Música, trata-se de "um par de enunciados musicais que complementam um ao outro em simetria rítmica e equilíbrio harmônico." (SADIE, 1994: 32). Ou ainda, enunciado complementado pelo consequente. Para Schoemberg, é a primeira parte de um período musical. (DOURADO, 2008: 27).
} 
condicionado pelo significado hipotético” (ibidem), ou seja, a composição, segundo Meyer, será constantemente expoente de ideias, com variantes e suas novidades, seguido de resoluções ou reorganizações, o que compele ao próximo significado;

(iii) que indicam significados determinantes: os que surgem das relações existentes entre os significados hipotético e evidente, assim como o desenvolvimento geral da composição musical. Com isso, este significado, determinante, surge com a compreensão da obra completa, isto é, surge com a experiência completa apreendida dos outros dois significados (MEYER, 1956: 38): o total de significações gerados pelo estímulo experimentado.

Os significados, da forma como estão apresentados por Meyer, serão percebidos pelo ouvinte em uma ação de tensão entre forças de expectativas: uma ambiguidade entre os significados hipotéticos e evidentes, ou ainda, como mais ou menos determinantes. Com isso, aponta a ambiguidade, isto é, o relacionamento entre significantes como gerador de afetos, indicando a escolha ou acomodação dos sentidos pelo ouvinte. Assim, a análise musical pode partir da formação das expectativas para compreensão dos sentidos. (idem: 43). Alinha a este processo uma conduta de formações de sentidos, estabilizados pela criação de estilos ou pela experiência estilística compondo uma linha de comunicação compositor/público. Os estilos fornecem normas, códigos dentro de um sistema, que permitem transportar as ideias musicais. O que parece requerer habilidade do compositor é o uso desse estilo, suas aparições e reclusões, suas repetições ou isolamentos, dando o sentido discursivo que pretende. Assim como o uso reconhecido de alguma dessas figuras, a repetição, por exemplo, torna-se eficiente, passando ao processo de variação dentro de uma célula, e assim, criando motivos ou clichés.

"um estímulo ou gesto que não aponta para o despertar de expectativas de um evento musical subsequente ou consequente não tem sentido. Porque expectativa é em grande parte um produto da experiência estilística, música em um estilo com o qual estamos totalmente desconhecidos é sem sentido. " (MEYER, 1956: 35)

O significado compreendido pela música é fruto da expectativa, seja ela impulsionada pela experiência, pela formação de códigos rápidos ou a exibição repetitiva de motivos musicais. A observação da repetição de Meyer parece aliar-se aos traços redundantes de Jakobson que, entre grupos relacionais elencados pelo feixe de 
traços salientes, mantêm-se eficientes na comunicação pela redundância, capazes ainda de exibir tipologias de padrões musicais como descritos por Springer.

As condições para a geração de significados musicais aqui apresentadas não se relaciona com outra proposta musical da mesma época em que avaliava a composição como reordenadora de elementos dispostos dentro de um estoque, possível de uma construção discursiva semelhante à escrita linguística. Essa teoria foi aplicada ao repertório das composições eletroacústicas e teve como teórico e crítico o compositor Iánnis Xenákis. Em seu Musiques formelles, de 1963, Xenakis indicou um sistema de composição que passou a ser conhecido como estocástica, por combinar os elementos de um possível “estoque” musical baseado na teoria matemática do jogo de Markov (BENT; DRABKIN, 1987: 64-5). Diferente das análises direcionadas à era Barroca ou Romântica, essa teoria parecia mais crítica do que metodológica, uma vez que denunciava as análises linguísticas e cibernéticas como “dissecadoras” (ibidem). Contrariamente, a teoria de Meyer entende a expectativa como formadora dos significados musicais, e ligada à teoria da informação com resoluções sobre a codificação diante de ruídos, e estes capazes da construção de referências no desenvolvimento da estrutura. A expectativa na música se relaciona ao efeito de previsão do ouvinte e, da mesma forma, convoca a presença de um ritmo geral, construído por elementos de espera e suas conclusões, talvez entre acontecimentos e exercícios da escuta. A teoria de Meyer, nos parece, fornece argumentos para a compreensão da música como um léxico, distanciando a ideia da construção musical como uma gramática musical rígida. 
Capítulo 3:

Tensividade no cinema musicado 
3 - Tensividade no cinema musicado

Tendo como referências as teorias expostas até aqui, buscamos uma união conciliadora e coerente que auxilie na análise da música predicadora de sentidos no cinema. A busca de um eixo metodológico para este trabalho depende ainda de argumentos de autores e suposições sobre estas possíveis coexistências conceituais das áreas científicas aqui aplicadas. Portanto, mantendo o apoio principal na Semiótica Tensiva, estabilizada por Zilberberg, somaremos os conceitos referenciais de Shaeffer e Meyer, entre outros, permitindo-nos observar a estratégia organizada do meio cinema, construtor de uma dinâmica de transmissão de afetos. Dessa forma, percebemos a produção fílmico/musical dos meios de comunicação de massa preocupar-se com a eficiência da informação dirigida ao destinatário, construindo sentidos sobrepostos pela predicação musical sobre o sentido fílmico: uma construção do estilo patêmico destinado ao público. Essa dinâmica de transmissão de afetos, desenvolvida pela organização do discurso midiático e analisada pela recepção em um público, pode ser agora abordada explorando o reconhecimento de isotopias fílmico/musicas, até suas tentativas retóricas.

Embora não seja de nossa vontade analisar a variedade e possibilidade analítica do público envolvido em mercados e serviços, bem desenvolvida no campo da semiótica (FLOCH, 1992, 2014; METZ, 1980; DURAND, 1974), devemos abordar este público como destinatários envolvidos com o cinema, ou seja, sencientes ao discurso cinematográfico e captador da enunciação fílmico/musical. Sua posição na argumentação deste trabalho é da ordem da organização dos vetores dos meios de comunicação de massa que, desde suas aplicações mais remotas até os recentes estudos sobre meios, apontam a direção das atenções ao reconhecimento de manifestações dos diversos públicos e seus consumos/reações/motivações. Deveremos então organizar uma ótica sobre os recursos apresentados pelos meios, percebendo seus elementos destinados ao público. Esse reconhecimento proporcionará uma posterior comparação e organização, permitindo à Semiótica Tensiva exercer sua análise. 
A apreensão das associações entre cenas fílmicas, e posteriormente entre filme e música, indicará os processos de enunciação do cinema musicado, levando este estudo à observação dos estilos, além da observação sobre a estrutura, sua ordem dentro de níveis e funções. Dessa forma poderemos proceder diante de uma análise fílmica/musical escolhida.

\section{1 - Poética cinematográfica}

Tratar a música composta para a cena de cinema envolveria processos de composição musical e suas aderências aos costumes fílmicos, ou ainda, envolveria uma coleção de exemplos da aplicação da música no cinema, sua possível redução e suas localizações e comparações. A análise nesse sentido teria uma face prática e seria uma explicação conceitual do que pode e do que não pode ser feito, isto é, do que deu certo e do que ainda não se sabe se o acerto foi proposital ou não. Enfim, esta seria uma visada sobre a possibilidade empírica do trabalho composicional. Se tratarmos essa composição dessa forma, teremos uma proposta especulativa e manipulatória, uma vez que caberia ao autor das comparações e reduções os julgamentos conclusivos. Ao contrário, neste capítulo pretendemos observar o sentido musical sobre as cenas fílmicas, em outras palavras, uma ótica sobre a música que recobre a cena fílmica e preocupa-se com a recepção sensível em seu público. Ao invés de redução dos fragmentos musicais e fílmicos, propomos o reconhecimento de elementos, isotopias, além de seu entendimento como frases, sintagmas que se unem e se aliam compondo um discurso. Seremos guiados pela coerência de formas reconhecíveis, de variações permanentes ou não-variações, além da possibilidade do reconhecimento de temas musicais e fílmicos. Esse universo a ser compreendido apoia-se em nossas referências do universo cinematográfico, multimidiático, televisivo, e por fim, de nossas referências naturais da esfera do conhecimento.

\subsection{1 - Isotopias fílmico/musicais}

No final da década de 1920, o diretor e ensaísta Sergei Eisenstein descreve a composição do drama exposto em um filme como uma série de conflitos a serem apresentados e resolvidos (2002: 49-71). Produtor, diretor de filmes e autor de análises, 
Eisenstein localiza esse pensamento em oposições, construções necessárias ao desenvolvimento das cenas, uma vez que estes conflitos oposicionados, de volumes maiores e menores da densidade visual, do claro e do escuro, da cena panorâmica ou em close, entre outros, darão a noção de um contraponto audiovisual das cenas. Dessa forma, procura uma sintaxe do cinema (ibidem) chegando ao entendimento de tipos de montagens: fragmentárias, de movimentos artificiais ou emocionais (idem: 60-4). Nesta última, a chamada emocional, descreve a composição fílmica como apresentações de sequências associativas e temáticas, não sendo obrigatoriamente de mesmo conteúdo, mas que mantenham elos conceituais. O exemplo dado pelo autor é sobre o filme A greve ${ }^{25}$, de 1925, que mostra um conflito entre policiais e grevistas se transformar em uma verdadeira chacina. As cenas de combate e fuga dos trabalhadores grevistas são intercaladas com cenas da atividade de um matadouro.

${ }^{25}$ Stachka - 1925 . 
Figura 31 - Story Board - A Greve (cena do Matadouro)

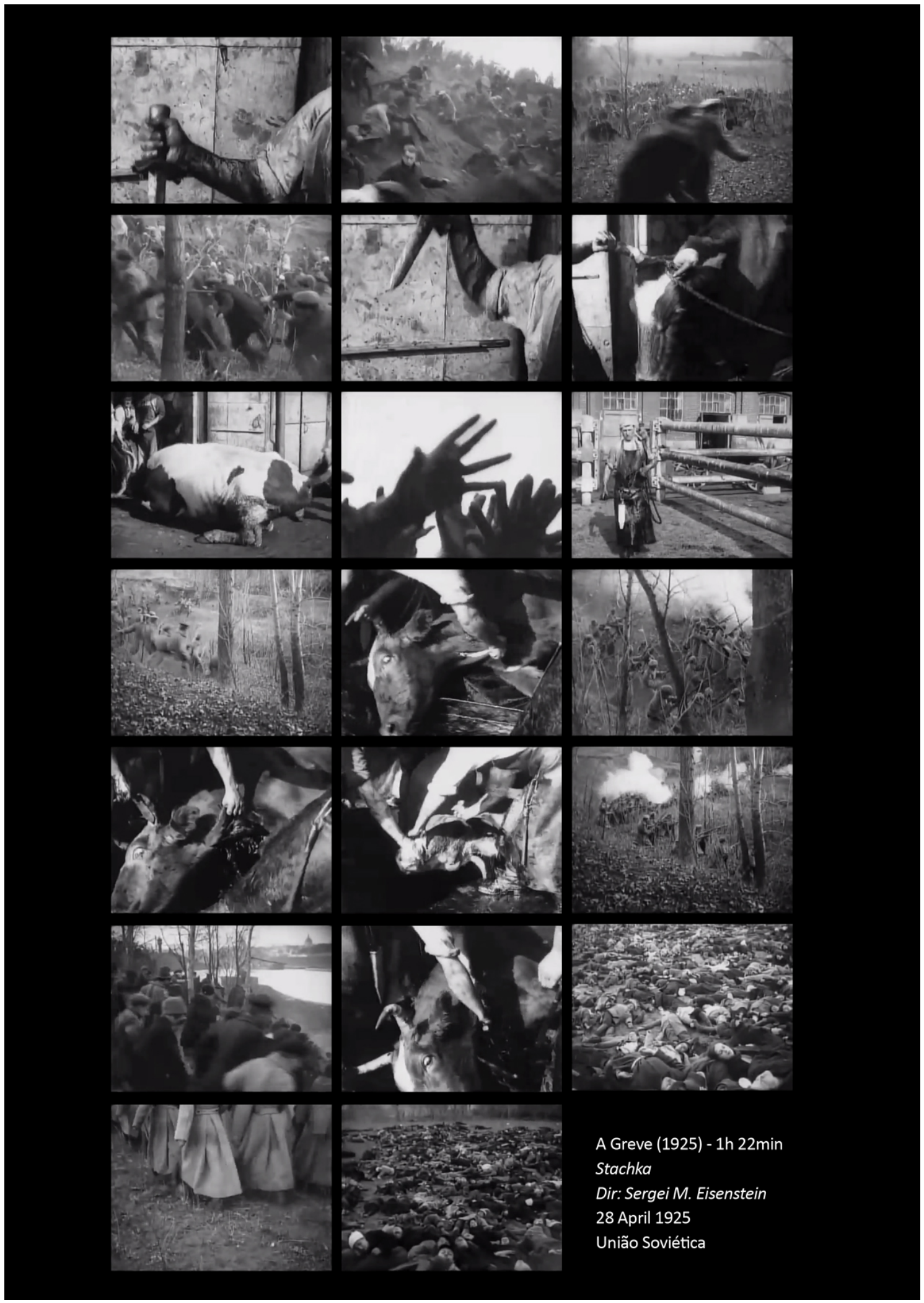

O matadouro em questão não faz parte da narrativa e serve para ilustrar uma sensação. A relação das breves aparições do matadouro intercaladas com a opressão vivida 
pelos trabalhadores parece-nos clara: são trabalhadores oprimidos, retalhados, sofrendo um verdadeiro abate de suas vidas pela ação opressora da polícia. Existe uma proposital relação entre as cenas ilustrando figuras comuns, indícios de coerências capazes de fazernos recobrar a analogia entre elas. Mesmo com seus sistemas de valores diferentes, parecenos equivalente, ou seja, suas conexões estão asseguradas e conduzem a uma coerência discursiva. Isso constrói um novo sistema de valores do conjunto do discurso, dando a visão das funções das cenas pelas relações. A este sistema damos o nome de semissimbolismo (FONTANILLE, 2012: 136-7).

\begin{abstract}
"O semissimbolismo é uma das formas da estabilização do sentido no discurso: ele o estabiliza, tornando-o mais específico. Por um lado, ele lhe fornece uma forma imediatamente reconhecível (ele 'iconiza' o sentido discursivo); por outro, ele o submete a uma condição de correlação própria a uma enunciação particular.” - grifos originais (Fontanille, 2012: 138)
\end{abstract}

Na sequência fílmica de Eisenstein, os cortes entre operários e matadouro só pode ser reconhecido e analisado como linguagem se executado o processo do semissimbolismo, uma tentativa de relação códica entre as cenas. Mesmo que o semissimbolismo tenha sua utilidade em textos linguísticos, sua apreciação em análises não linguísticas tem sido uma constante. Essa explicação seria suficiente se não nos pautássemos pela Semiótica Tensiva que compreende a relação entre grandezas de desvio escalonáveis, relacionadas com suas concentrações e difusões, ou seja, a intensidade com a extensidade. No caso da cena descrita, as relações descobertas pelo semissimbolismo seriam úteis para a descoberta da relação objetal, portanto extensiva e concernente ao universo inteligível. Falta-nos a relação subjetal, aquela que entende os desvios ligados ao campo do sensível e apoiada no eixo intensivo. Como complemento do exemplo, nossa abordagem ficaria assim:

operários : policiais : : gado : matadouro

Uma primeira leitura da sequência seria exposta dessa maneira, apoiando-nos nas isotopias discursivas. Ou seja, os operários são para os policiais o que o gado é para o matadouro. Em seguida, analisamos a posição semântica do fenômeno (idem: 139)

submissão : tirania : : inferioridade : superioridade 
Teríamos a relação direta, e coerente aos olhos do filme, em que demostra operários submissos e policiais tiranos. Esta é uma compreensível análise semissimbólica, porém, superficial para a análise Tensiva. No exemplo, é importante observar o eixo sensível do operário que sofre a tirania, sua relação com a morte, a falta de liberdade e a opressão. Em um matadouro o gado caminha para a morte e, ao que parece, o diretor do filme quis passar essa imagem do operário grevista que padecerá em breve. Na Semiótica Tensiva, a submissão e a tirania manteriam suas relações de extensidade, portanto objetais e partes do contínuo do discurso visual. No eixo intensivo, e em relação do operário a caminho da morte, teríamos uma relação de maiores ou menores sensações ligadas à perda, ao sofrer, a liberdade.

Figura 32 - Gráfico Tensivo V - A greve

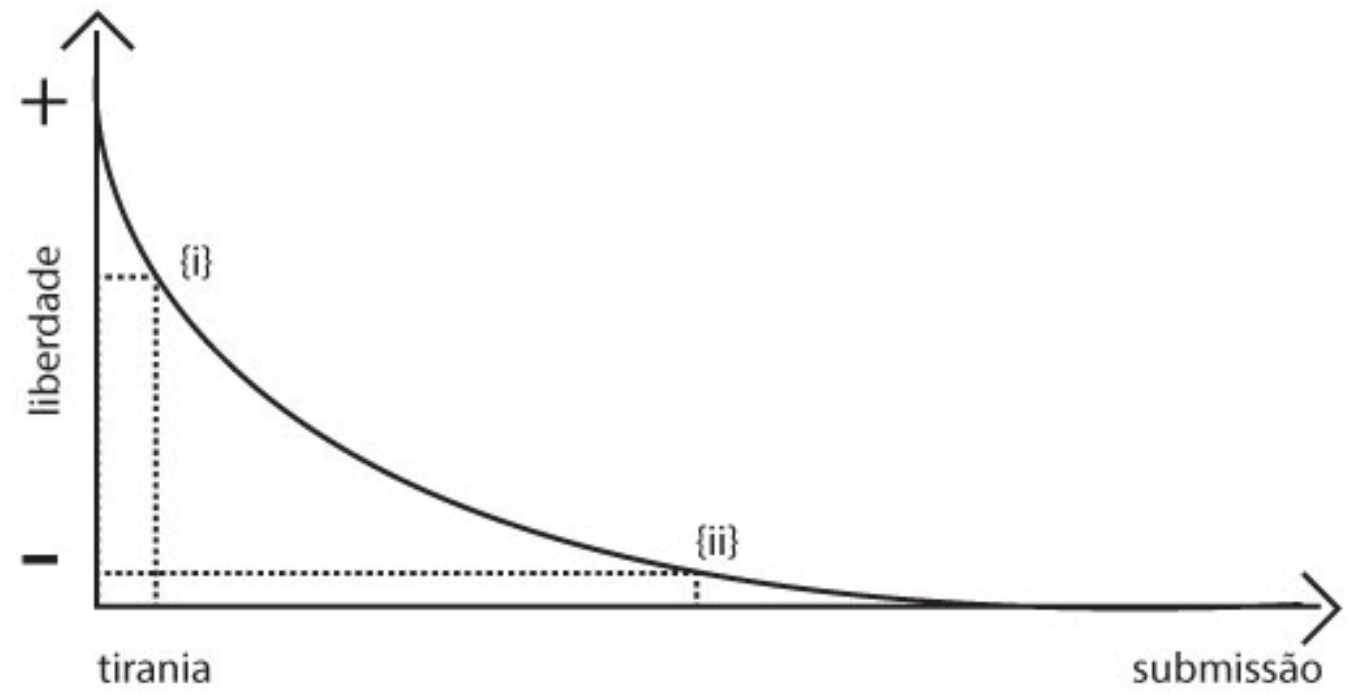

Interpretando do gráfico acima, podemos observar que: (a) não se trata de uma submissão por parte do operário, trata-se, portanto, de uma ação opressora sobre a liberdade desses operários, logo, da progressão da tirania até a perda da vida, como o gado; (b) visto de um momento inicial $\{\mathrm{i}\}$ até o final da sequência $\{\mathrm{ii}\}$, existe uma diminuição de liberdade também até a morte. Assim, não se trata de uma questão de vincular o operário como submisso, mas, pela leitura Tensiva, esse operário é gradualmente oprimido até sua queda total. A mudança no termo encontrado, e não mais na análise semissimbólica, nos traz uma melhor reflexão da sequência exposta e torna clara a possibilidade de análise de relações entre isotopias. Mesmo que no exemplo do filme de Eisenstein, as possibilidades de análises se ampliem quando observamos o filme completo, podemos perceber o 
contraponto descrito pelo autor. As cenas, embora distantes conceitualmente, mantêm sua sequência associativa, dando ao espectador a noção de um contínuo. Dessa forma, mesmo que os sistemas de valores sejam diferentes, como as cenas díspares de Eisenstein, podemos perceber suas coerências, efeitos associativos que nos fazer relacionar objetos diferentes. O semissimbolismo é útil na primeira abordagem sobre os diferentes objetos e sistemas enunciados, devendo ser complementado pela Semiótica Tensiva.

Esta parece ser a primeira estrutura visível da análise fílmico/musical. No entanto, faltam-nos ainda respostas sobre a posição da significação através de isotopias do filme e da música. Por exemplo: como reconhecer uma atitude fílmica significante e possível de relação com ocorrências musicais? Ou ainda, como reconhecer apenas as atitudes fílmicas? A resposta está na possibilidade de associação das cenas, ou músicas, com as ações de denotação e conotação. A significação das cenas fílmicas pode ser avaliada se observarmos sua motivação pela analogia de relações denotativas e conotativas (METZ, 1972: 130).

Descrito como resultantes de procedimentos no Dicionário de Semiótica (GREIMAS/COURTÉS), a denotação e a conotação estão a cargo do entendimento de um objeto pela quantidade de relações atribuídas a cada um. Inicialmente, se atribuída a uma significação direta e simples será denotação, mas, se ultrapassar essa significação, será conotação. Essa concepção inicial não é suficiente para o entendimento das isotopias fílmicas, nem tampouco as musicais. Segundo a análise de Metz, descreve a analogia direta como denotativa: a relação direta de imagem e objeto representado, por exemplo. A conotativa contém a analogia, mas essa não é perceptiva: ela é motivada pela superação de sua significação. Trabalhando com o simbolismo inicialmente, a denotação parece ter um primeiro momento de associação, até superá-lo e perceber-se conotação. No exemplo de Metz: “(...) diz-se que a cruz é o símbolo do Cristianismo porque, por um lado, Cristo morreu numa cruz (=motivação) e também porque, por outro lado, há muito mais coisas no cristianismo do que numa cruz (=superação).” - grifos originais, (METZ, 1972: 131). Isso demanda a ideia de que a conotação está relacionada a um grupo de objetos: a resultante de membros individuais combinados (HJELMSLEV, 2009: 123). No entanto, sua motivação é parcial deixando-a com a tarefa de reconhecer códigos e convenções (METZ, 1972: 131). Metz dá um exemplo interessante sobre a parcialidade da motivação da conotação:

“(...) num filme falado em que o herói, entre outras particularidades diegéticas, costuma assobiar os primeiros compassos de determinada melodia (...) a simples presença dessa melodia na faixa sonora bastará para evocar claramente o conjunto do personagem num trecho posterior da narração (...); e não é sem conotação forte que o personagem será assim designado.” (ibidem). 
O herói foi arbitrariamente simbolizado por um traço marcador de uma conotação. Mesmo que o esse herói tivesse outros traços que o caracterizassem, este foi o escolhido, causando um significante de conotação. Se escolhido outro, seria também outro o significante de conotação, mas isso não alteraria o significado, pois representaria o mesmo personagem: "(...) há, portanto, uma parcela de arbitrário na relação entre significantes de conotação (a melodia) e o significado de conotação (a personagem)." - (METZ, 1972: 131). Esta relação da melodia escolhida e o personagem contentor da melodia parece ter paralelos com a explicação de Hjelmslev sobre a divisão do conotador entre um sistema semiótico e um uso semiótico. A fala de alguém, segundo Hjelmslev, em oposição a outro falante, pode ser reconhecida pelo seu uso específico de estilo ou característica marcante, mas não pode ser reconhecida por seu sistema específico (HJELMSLEV, 2009: 123-4). Essa diferenciação será utilizada por Metz ao interpretar os códigos advindos da conotação: o uso, mesmo que dentro de um sistema, mostra o estilo enunciado. A escolha desse estilo é arbitrária, podendo pertencer ao sistema, se a escolha da narrativa assim quiser. O uso da ação, portanto, fica condicionado a escolhas que construam o discurso dentro da objetividade ou organização escolhida: forma-se uma construção sintagmática. Se considerarmos a posição de tais figuras fílmicas e musicais no sintagma, poderemos perceber formações conotativas, como o assobio do herói, sendo reformuladas, ou ainda, re-conotadas, chamadas por Metz de suplementos de significação (1972: 132). Este suplemento não é arbitrário, uma vez que cada localização e repetição de figura simbolizarão situações narrativas ou encontros com situações culturais (METZ, 1972: 1312), ou seja, situações pré-formuladas.

A observação sobre as isotopias percebidas, motivadas, como conotação e distribuídas no sintagma tem seus paralelos com a teoria analítica de Meyer quando descreve os gestos musicais. Na descrição do autor, o gesto, em seu exemplo na construção melódica ou em cadências harmônicas, pode ser reconhecido pelo analista se observado o gesto melódico. Essas ações musicais aparecem como funções, recorrentes estruturas usadas em inícios e términos, variações, temas; ou por suas construções de antecedente/consequente. A leitura de uma melodia, tema ou cadência pelo antecedente/consequente remonta o conceito de sentença musical guiada por sua compreensibilidade (SCHOENBERG. 2015: 51). Composto pelo par de enunciados, o antecedente e o consequente, estes se complementam um ao outro mostrando, em ordem, uma ideia e o complemento "natural” desta ideia. Essa estrutura frasal é observada desde 
tempos remotos da música e teve seu desenvolvimento analítico nas teorias relacionadas às fugas, principalmente no período denominado Barroco musical (Encyclopédie de la musique: 22). Schoenberg avalia ainda esses termos como partes de obras, sendo, por exemplo, um primeiro movimento em antecedente e o segundo em consequente, além de cada movimento conter diversos antecedente/consequentes em frases e períodos (SCHOENBERG. 2015: 246). A concepção dessa ideia é muito recorrente em composições, fazendo parte da análise de muitos estudiosos. Meyer tem uma aproximação especial nesse sentido, a ponto de classificar o movimento antecedente/consequente como um dos reconhecíveis e previsíveis, tornando a composição uma possível sequência de ocorrências propostas pelos antecedentes.

\footnotetext{
"Um motivo, uma frase, ou um período é definido por certo grau de fechamento. Sobre o nível de seu fechamento - o nível em que é entendido como um evento separável - é uma entidade relativamente estável, formal. Embora definido por processos internos, uma vez fechado, não é um processo, mas uma 'coisa’ palpável. Quando, por sua vez se combina com outros eventos no mesmo nível e, assim, torna-se parte de um evento de nível superior, funcionando novamente de uma forma processual.” - tradução livre (MEYER, 1972: 90)
}

Estas combinações "processuais” da música, ocasionadas pela necessidade de entendimento e organização auditiva e movida por um entendimento cultural e processual, indicam uma sintaxe composta de eventos subsequentes construtora de níveis frasais e periódicos até o entendimento de um "fechamento", consequente, da abertura proposta pelo antecedente (MEYER, 1972: 90). Essas sensações de abertura e fechamento são subjetivas do observador e propõem uma construção de "entidades formais” sempre binárias e passíveis de oposição: -“A partir disto, parece que o mesmo evento pode ser caracterizado como qualquer forma ou processo, dependendo do contexto hierárquico a ser considerado.” - tradução livre - (ibidem). Partindo da formação do antecedente/consequente ou das configurações aparentes e recorrentes em obras, aberturas e cadências finais, Meyer indica o uso de “padrões arquétipos” (p. 213) possíveis de reconhecer qualquer evento musical sendo derivados de outros eventos. Não que estes padrões possam ser ordenados em regra, como gap-fill melody de Meyer (ibidem), mas são reconhecíveis e utilizáveis como usos de um sistema:

\footnotetext{
“Assim, para que um falante de uma língua entenda e responda a declarações verbais de acordo com os tipos a que pertencem - prosa ou poesia, exclamação emotiva ou ao raciocínio lógico, a afirmação declarativa ou alternativo interrogativa - depende de um ouvinte competente” - tradução livre - (MEYER, 1972: 213-4).
} 
Constatada a operação de reconhecimento dos sistemas e seus usos, entendemos as construções dos sintagmas, musicais e fílmicos, assim como a colocação de seus elementos musicais em locais desse sintagma como a produção da comunicação percebida pela conotação. O que é re-conotado e previsto como suplemento de significação está constituído na distribuição transfrástica, e será enunciada de acordo com a necessidade do ritmo geral da peça, filme ou música, visando sua eficiência comunicacional.

As localizações das isotopias fílmicas e musicais têm agora uma melhor aparência e são mais possíveis em uma análise. O reconhecimento de isotopias no sintagma geral, ou em períodos, proporciona agora a leitura dos traços salientes e redundantes, e desta forma, o reconhecimento também das confirmações de itens prováveis e suas rupturas. Esse desenvolvendo prevê o uso dos ruídos, abordado no segundo capítulo desse trabalho, como melhora da eficiência da comunicação utilizando-se da expectativa e da resolução dessas até a construção do ritmo: os acontecimentos e exercícios da Semiótica Tensiva. Parece-nos possível chamá-lo de sintagma relacional uma vez que tende ao apoio dos termos contidos em si, reutilizando-os constantemente, para obter sentido. O termo relacional, advindo da álgebra, descreve as variações de resultados e conteúdos em conjuntos numéricos: a alteração de um item de um único conjunto altera não só o resultado, mas a composição interna dos outros conjuntos associados ao primeiro alterado. Essa relação entre conjuntos relacionados entre si e vinculados ao significado do texto é visível na construção da análise fílmico/musical.

\section{$\underline{\text { 3.1.2 - Resposta emocional do espectador }}$}

“A música é tão ou mais capaz de louvá-lo (o Senhor) do que o edifício da igreja com toda sua decoração; é o maior ornamento da Igreja." Igor Stravinski ${ }^{26}$

Ao ser confrontado sobre suas composições Canticum Sacrum, Threni e Missa, Stravinski aborda, além do reconhecido poder da música litúrgica exposto no excerto

${ }^{26}$ (STRAVISKI; CRAFT. 2010: 102) 
acima, a forma composicional que a liturgia, principalmente católica, desenvolveu e praticou com as muitas finalidades em seus ordinários e extraordinários eventos. O próprio Stravinski entende que suas composições, que seguem um espírito musical da igreja, não seriam agora executadas pela mesma (STRAVINSKI, CRAFT; 2010: 102). O motivo mais aparente para essa não-execução pode estar na escolha do estilo enunciado diferente do código litúrgico. Parece-nos possível verificar que o espírito musical destinado à igreja seja comparado ao uso específico da parcial arbitrariedade, superado em sua significação pela conotação, entendido como código. Por mais que Stravinski ordene um sintagma com o estilo corretos, seus códigos não o serão.

Vemos a necessidade de uma composição ordenada entre estilo e código para que ocorra uma eficiência discursiva e sua aproximação com o espectador. No exemplo de Stravinski, parece-nos correto anotar a variação existente entre possíveis códigos ligados à liturgia católica. De um lado, um código musical concentrado e fiel ao repertório barroco, hinário, harmônico e dentro do que reconhecemos desse repertório, por exemplo; e do outro, um código difuso e distante do mesmo reconhecimento. Em análise, e com a finalidade de localizar essa observação dentro da Semiótica Tensiva, o estilo teria sua variação quanto a maior ou menor especificidade dentro de um sistema. Vemos a possibilidade do reconhecimento de termos diante de uma breve análise da relação entre estilo musical e os códigos litúrgicos:

Figura 33 - Gráfico Tensivo VI - Litúrgico/Profano

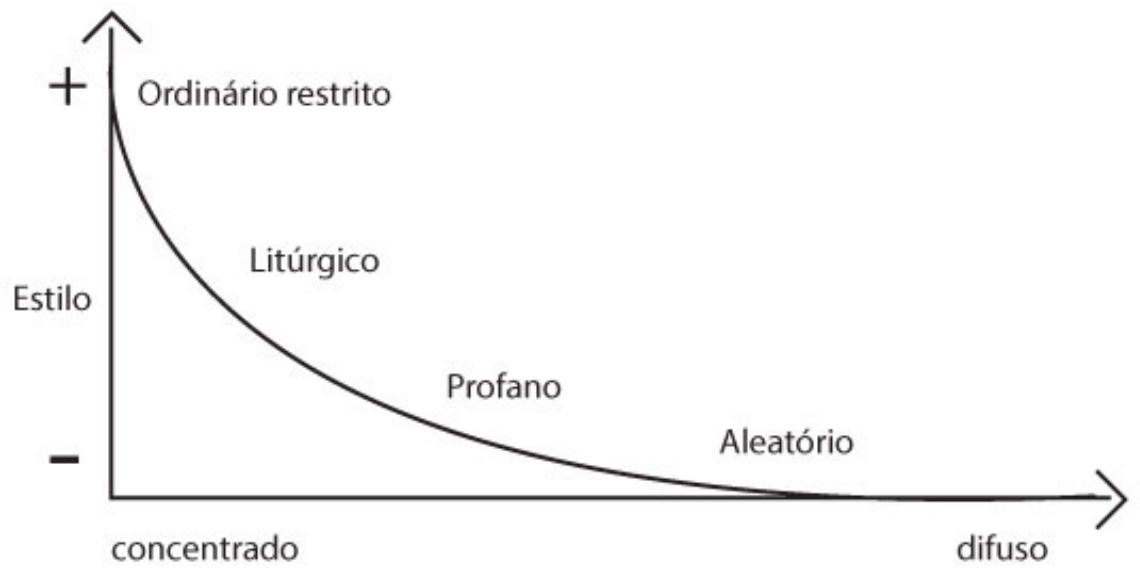

código 
O gráfico mostra que, além dos termos opositores [litúrgico] vs [profano], a extensão dos termos mostra a possibilidade da utilização de um possível extremamente litúrgico, e um extremamente profano, considerando as relações de códigos descritos acima. Podemos encontrar um local para música de Stravinski como de baixo estilo, embora de códigos concentrados. Isso procede se percebermos, em uma escuta detalhada da obra e de maneira superficial, a preocupação com conceitos litúrgicos, a ordem dos movimentos, seus títulos, etc; mas perceberemos também as dissonâncias, as quebras rítmicas, entre outros eventos distantes do estilo. Assim, a peça nos parece transitar abaixo do litúrgico, na verdade com ares de música profana.

Sem pormenorizar a composição em questão, sabemos que executamos uma leitura sobre uma parcial arbitrariedade, o assobio do herói complexo do exemplo anterior, interpretando o que foi motivado além dessa arbitrariedade: no caso do recente exemplo, os códigos litúrgicos. Os usos das especificidades dos códigos mostrarão o estilo: o que está com maior ou menor campo dentro do sistema escolhido. Embora entendamos a possibilidade de análise, devemos também entender a quantidade de escolhas e arbitrariedades em que essa análise se baseia. Essa leitura de códigos pode partir de uma difícil articulação no caso do vasto campo dos referenciais litúrgicos e da complexa música de Stravinski, mas não serão entraves diante dos meios de comunicação de massa. Nesse caso, o cinema é conhecido por carregar certa dualidade de referências, ou seja, carrega em si códigos específicos e códigos não-específicos. Por não serem compostos de modelos formais ou lógicos, os códigos cinematográficos formam unidades de aspiração à formalização (MARIE, 2012: 195), útil à análise semiótica que entende o código como um campo de comutadores: "um campo dentro do qual variações do significante correspondem a variação do significado e onde algumas unidades adquirem sentido uma em relação às outras” (ibidem). (i) O código específico do cinema é aquele vinculado ao material de expressão do filme: ângulos de câmeras, tipos de tomadas, de tratamentos, cortes e efeitos que dependem do conhecimento do processo da produção para a interpretação. Esse tipo de código é útil ao analista, mas será pouco usado nessa abordagem analítica. Este “código específico” é chamado por Metz de código especializado, (METZ, 1972: 133-4) e o chama dessa forma porque não faz parte da esfera cultural: pelo menos dos espectadores que um filme pretende chamar a atenção. (ii) Os códigos não-específicos do cinema são aqueles constituídos de manifestações universais (MARIE, 2012: 195), o que Metz chama de cultural (METZ, 
1972: 134). Marie cita Hjelmslev indicando "um material de conteúdo coextensivo à totalidade do tecido semântico, ao universo social do sentido”.(Hjelmslev apud MARIE, 2012: 195). Este é o código que poderemos utilizar em análises pois este indicará as isotopias fílmicas de imagem, música, narrativa entre outros traços possíveis à percepção do analista. Como princípio especulativo de um método de análise, podemos indicar uma preferência pelos filmes que não dependam verticalmente da observação de códigos específicos e prosseguir no empenho dos códigos não-específicos. Essa necessidade inicial é justificada pelo próprio hábito das produções fílmicas de não abordarem nem mostrarem elementos não necessários. Isto é, praticamente tudo o que é visto ouvido e entendido é proposital no cinema. Metz descreve esse processo lembrando o im-segno de Pasolini ${ }^{27}$ e a não virgindade dos objetos em cena (METZ, 1972: 135).

Sendo possível o reconhecimento dos elementos de um percurso fílmico/musical, podemos então observá-los na distribuição sintagmática com a finalidade de selecionar suas aparições e seus "antecedentes/consequentes”. A conotação será reutilizada ciclicamente uma vez que o discurso, fílmico e musical, depende de reapresentação de elementos já expostos. Essa parece ser uma produção de códigos e estilos enunciados que referenciam os futuros códigos e estilos. Esse ciclo formulará novas significações permitindo a análise dos itens prováveis e rupturas geradoras de expectativas e resoluções. Percebemos a construção de um discurso preocupado com criação e reprodução de isotopias formadoras do ritmo geral, fazendo disso a manutenção da comunicação com o espectador. Considerando a experiência cultural do espectador, e sua afinidade com os códigos e os estilos, podemos prever as respostas emocionais diante do meio cinema. Os acontecimentos percebidos demandam uma volta ao controle emocional desenvolvido pelo ocorrido, ação já observada pela Semiótica Tensiva quando da análise dos “acontecimentos”. A variação entre acontecimentos e exercícios, suas rupturas e retomadas de controle, terão um ritmo peculiar em cada tipo de cinema pensado em atender às atenções e expectativas de seus públicos. Podemos dizer que os públicos são os controladores emocionais desse

\footnotetext{
27 Im-Segno: Pasolimi descreve um conjunto organizado de significações aparentes em filmes funcionando como analogias códicas. Assim, no cinema, cada representação de grupos sociais carrega seus códigos característicos produzindo um cinema manipulador de ideias. Ao final, concorda com a necessidade desses códigos - "im-segno é para o cinema o que a língua é para o escritor".
} 
processo, uma vez que são baseados nestes as propostas de produções de cinema. Somos ação e reação dos meios de comunicação de massa.

Percebemos o uso de recursos próprios dos meios de comunicação de massa. O ritmo de uma narrativa fílmico/musical pertence ao enlace de circularidade proposto por Zilberberg onde, pelo reconhecimento de uma demarcação, declara a relação entre as partes (1996: 27). A circularidade se opõe à linearidade, de relações entre objetos, que será também útil na percepção do sintagma relacional. Na explicação de Zilberberg, o ritmo promove dois tipos de aspectos: o de segmentação, buscadora da repetição e da sensação de antecedência; e a demarcação, com seu arredondamento e linearidade. O produto dessa análise será a percepção de uma cumulação (ibidem), analisável e percebida pelo público. As repetições são as formadoras da rítmica discursiva que, sem repetir seus itens de forma idêntica, fará uma ação retórica discursiva. Essa será a maior ferramenta dos meios de comunicação de massa, capaz de tornar alguns de seus elementos permanentes e ao mesmo tempo inovadores diante de seus espectadores (ADORNO; EISLER, 1981: 59).

\section{2 - A predicação musical no cinema}

A observação sobre as figuras fílmico/musicais e a resposta emocional do espectador pode ser considerada os primeiros passos na construção de uma análise. Sua aplicação dependerá do reconhecimento das isotopias musicais e fílmicas, assim como seus relacionamentos. Essa relação de conformidade, desenvolvida por Meyer, é percebida pela forma em que os sintagmas musicais e fílmicos são apresentados, dependendo do reconhecimento dos elementos ali expostos pelo espectador. No desenvolvimento de uma análise, falta-nos abordar a construção do sentido que música e cenas fílmicas, somadas, nos mostrarão: sua forma e sua leitura, apontando para a soma de timias.

Em uma impressionante cena do filme Psicose ${ }^{28}$, de Alfred Hitchcock, o segundo assassinato, o do detetive Arbogast em uma escada na casa suspeita, foi descrito pelo diretor como extremamente trabalhoso pelo cuidado que a equipe de produção teve com câmeras, edições e música. Ao descrever o resultado do empenho dessa cena, o diretor comenta: -“Era exatamente como a música: a câmera lá no alto, junto com os violinos, e de

\footnotetext{
${ }^{28}$ Psicose: 1960.
} 
repente a grande cabeça, junto com os instrumentos de sopro.” (TRUFFAUT; SCOTT, 2004: 279). O resultado mostra, além da preocupação com os exatos momentos de cada cena aliado a cada sonoridade da orquestra, a proposta de predicação musical sobre a cena filmada com a finalidade de transmitir estados patêmicos ao espectador. O processo que levou a esse refinamento de ações fílmico/musicais pode ser observado pelo desenvolvimento histórico/técnico do cinema, sempre aliado à vontade de estabelecer contato afetivo com seus espectadores. Desde o advento do som no cinema, a reeducação da escuta, ocasionando quase uma doutrinação da escuta musical, e esta aliada às imagens, levou o meio cinema ao entendimento estável de recursos musicais que auxiliassem a transformação de afetos pela fusão fílmico/musical. Podemos elencar duas possíveis impressões sobre essa fusão, além da vontade de mantê-las unidas e renovadas. A primeira é conceitual, ou seja, parte de uma observação prática do fenômeno e é o que podemos chamar de expansão das sensações. A segunda faz parte de nossa análise e é derivada do ato de predicação.

Essa expansão das sensações trata de um efeito psicofísico da experiência na sala de cinema e mostra a capacidade que os sons, e principalmente a música, tem de saturar ou confundir o discurso fílmico. Essa experiência é a abordada por Chion quando compara os limites em uma sala de exibições (2011: 32-3). A tela, descreve o autor, tem por obrigação um limite que induz a visão, o que não ocorre com o som do cinema. A primeira impressão que podemos apontar é a importância que a música, ilimitada, tem sobre o filme, limitado, e como ela pode e é usada para relacionar certa "liberdade" diante das cenas fílmicas. Essa observação nos faz reconhecer importantes atividades do cinema musicado: (i) o filme, as imagens em sequência, suas cores e variações possíveis, expressa o espaço, a escolha de locais, de pessoas em lugares, de ambientes, portanto de variações espacial; (ii) a música, assim como os elementos sonoros que chamamos de não-diegéticos, ou seja, fora da narrativa e sobrepostos a ela, expressa a indução do afeto, a proposta de saturação do local impresso pelo filme.

A predicação reconhece o produto dos eventos do discurso fílmico somados ao discurso musical. Observa a modalização e aspectualização do percurso e avalia a fusão fílmico/musical. Além de apoiar-se na descoberta da indução afetiva musical sobre a espacialidade fílmica, indicando a construção de um quadro tensivo. Conclui-se, em primeira análise, que as descobertas de termos relacionados ao filme, assim como os diálogos e os eventos, são distribuídos no eixo extensivo, já que conterão, para nós, conteúdos objetais relacionados ao evento total. Desdobra-se daí a proposta, portanto, de 
que a música do filme, subjetal, seja conformada no eixo intensivo, propondo a observação das possíveis variações musicais. As variações de espaço extensivo e música intensiva devem ainda ser determinadas pelo analista, permitindo observar o percurso pela modalização e, posteriormente, pela predicação. A modalização parece ser o elemento que trará à luz as variações e não somente as transformações percebidas na observação do sujeito. Aqui as variações podem ser interpretadas pelo “sujeito” musical e fílmico, ou até por um não sujeito, isto é, a ausência ou corte de um fragmento musical. O predicado será interpretado como modal, e de possível relacionamento com outro predicado e com a possibilidade de um reconhecimento no espaço tensivo.

Parece-nos importante perceber a possibilidade de relacionamentos entre logos, um intensivo musical e outro extensivo fílmico, permitindo a interpretação passional de cada logos, de cada sintagma modalizado e aspectualizado dentro de suas possibilidades. A observação no espaço tensivo mostra a recção, a predicação, da música sobre o filme.

A predicação aqui desenvolvida liga-se a certo tipo de empilhamento de sentidos, estimulado pela repetição de ações modalizadas, podendo ser consideradas como aumentos de cargas tímicas. Este acento é descrito por Zilberberg como um "quantum imaginário de cargas tímicas” (2012: 29), capaz de prever um êxtase, positivo ou negativo, e passível de acréscimos de acordo com a quantidade e variação de concessões no percurso (ibidem). No caso da música regente do afeto no percurso, pode-se observar o predicado desenvolvido pela cena e depois somá-lo ao predicado musical. Essa estrutura seria representada assim:

Figura 34 - Gráfico Tensivo VII - Carga tímica

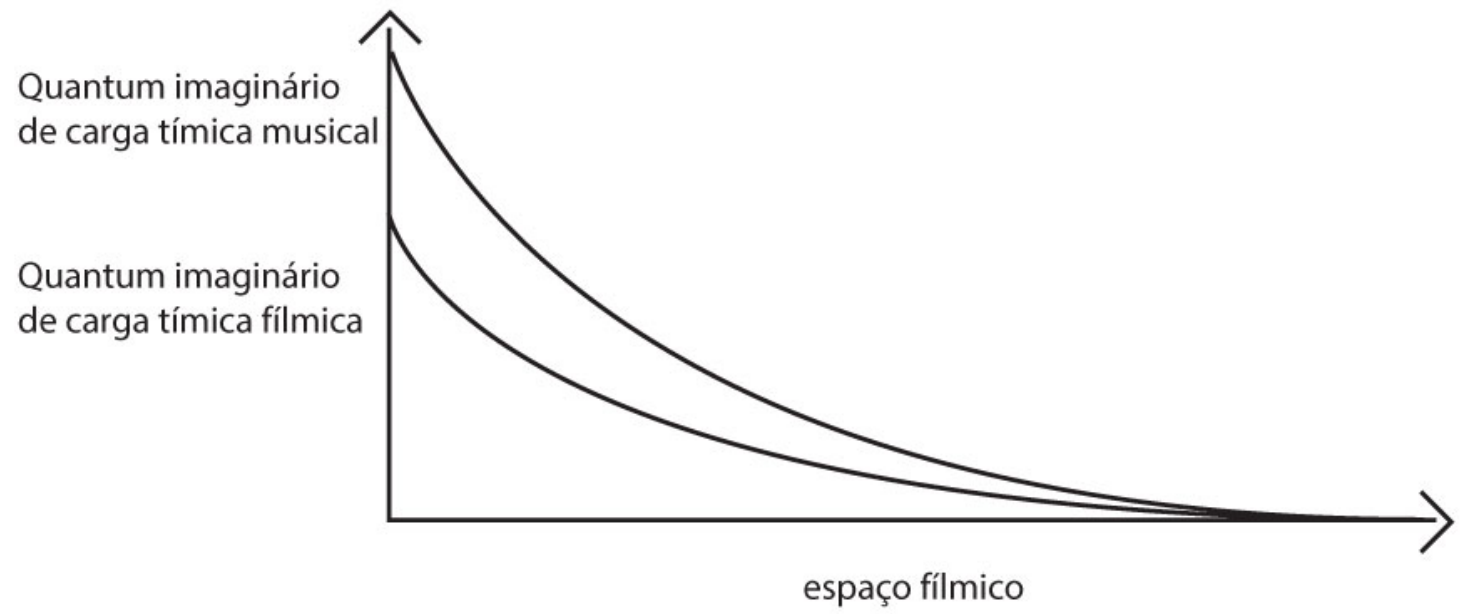


Isso confirma a posição de Zilberberg de que a predicação está ligada diretamente com a observação da timia e da constatação passional das cenas tensivas. A música representa o "mais um” de timia possível pela ação concessiva, somada a outra concessão, a do filme. Isto é, os acontecimentos do filme são recobertos pelos acontecimentos da música construindo a sobreposição. Da mesma forma, as modalizações percebidas passam por uma predicação e confirmam a presença da sobreposição. O efeito de sobreposição deverá ser analisado por suas relações, tema que veremos adiante. Na construção da expectativa descrita no discurso musical, Meyer observa sua formação através da resposta emocional do ouvinte quando exposto aos traços redundantes e distintivos. Assim, a confirmação ou não de elementos musicais reconhecíveis serão preponderantes no reconhecimento dos afetos ligados à cena. Vale aqui ressaltar a conformidade existente entre as duas teorias visto que, tanto para a Semiótica Tensiva quanto para a Teoria de Meyer, as oscilações do contínuo serão as promotoras das timias. O aumento reconhecível no volume de timia é frequentemente utilizado pelo discurso midiático do cinema com variações e acentos regulados, elementos importantes na construção dos percursos. Podemos, dessa forma, observar o ritmo apontado pela Semiótica Tensiva, indicador do afeto regente do inteligível. A percepção do espectador não observa o tempo físico, mas o ritmo sensível proposto pelos sobrevires fílmicos musicais, deixando boa parte da percepção desse ritmo para música da cena. Soma-se a essa sensação a percepção das fusões entre frases, musicais e fílmicas que compõem os periódicos acontecimentos e seus períodos de recuperação. A constatação do ritmo eleva todos os elementos do discurso ao título de auto reguladores e organizados, visando a eficiência da comunicação.

Percebemos duas formações componentes no ritmo geral: a primeira atua sobre o citado espaço extensivo do filme regido pela tonicidade da música, a profundidade indicada por Zilberberg; a segunda trata da espera criadora de afetos, o ritmo segundo o autor. A distribuição de imagens em movimento descrevendo espaços, portanto deixando a análise por suas variações de aberto/fechado, exterior/interior e repouso/movimento, regidos pelo tônico/átono musical, em traços a serem arbitrados pelo analista, demonstra a distância entre as extremidades dos sobrecontrários e, assim, o afeto. Na verdade, pode-se chegar à intensidade pelo caminho inverso: observando primeiro o afeto e formulando os termos. Por outro lado, a disposição dos acontecimentos distribuídos em períodos de sobrevires e recuperações trarão a visão das esperas, estas dirigidas pelas frustrações e satisfações atribuídas como formador de expectativas. São movimentos de euforia e disforia ligados à continuidade, causadores do relaxamento de sua ruptura, sua 
reorganização e sua continuidade. Criam-se ciclos retóricos importantes para a manutenção da atenção dos espectadores.

\section{3 - A argumentação da música no cinema}

"É preciso desenhar o seu filme como Shakespeare construía suas peças, para o público."

Hitchcock ${ }^{29}$

Parece-nos possível interpretar a argumentação da música no cinema como uma terceira parte da análise. Esta que passou pelo reconhecimento de isotopias até a percepção da predicação e seus ritmos, aponta agora para o reconhecimento de um fator retórico do meio de comunicação. Estes níveis são importantes para o reconhecimento de elementos em uma análise, visto de seu uso constante e necessário. A primeira observação sobre essa argumentação se refere ao espectador, tão comentado e citado no decorrer do trabalho, e que agora parece ter sua visibilidade exposta pela necessidade do objeto. Trata-se de um público ideal, ou ainda, um enunciatário ideal, aquele que pertence a um auditório e é aculturado dos elementos transportados pela mensagem do cinema. O discurso do cinema deve, pelas características que carrega, preocupar-se com este enunciatário que pensa, sente, opina e espera (FIORIN, 2015: 74). Pode-se assim dividir o auditório, ou a imagem que se faz desse, em dimensões: (i) uma dimensão ideológica, portanto da ordem do saber e do crer; (ii) uma dimensão patêmica, da ordem do sentir e (iii) uma dimensão perceptiva, da ordem do esperar (ibidem). A escolha do enunciador pelo meio e sistema que produzirá a enunciação depende do conhecimento dessas dimensões. Na verdade, depende de outras esferas da comunicação:

“Comunicar é agir sobre o outro e, por conseguinte, não é só levá-lo a receber e compreender mensagens, mas é fazê-lo aceitar o que é transitivo, crer naquilo que se diz, fazer aquilo que se propõe. Isso quer dizer que comunicar não é apenas fazer saber, mas principalmente fazer crer e fazer fazer.” - FIORIN, 2015: 76.

O fazer crer e o fazer fazer descritos por Fiorin demandam o pensamento da eficiência da informação proposto pela teoria da informação, entre outros elementos descritos nesse trabalho. Seria ainda a eficiência atingida pelo uso das figuras de

${ }^{29}$ (TRUFFAUT; SCOTT, 2004: 287) 
metáfora e hipotipose descritas pela retórica de Zilberberg. Na construção musical, essa retórica aparece na recolocação de elementos metafóricos/hipotipóticos, assim como nos filmes, atratores dos códigos, ou como chama Meyer, das contingências de alternativas (MEYER, 1956: 112). Passemos à observação da argumentação, assim como da criação de algumas figuras de retórica, na análise da música de cinema.

\subsection{1 - Figuras de retórica fílmico/musicais}

Dois aspectos são importantes na percepção dos períodos a serem analisados, os sintagmas que podem ser relacionados e relacionais. O primeiro é descrito por Benveniste quando enfatiza a frase, o logos, como instrumento de comunicação (BENVENISTE, 2005: 139) e o predicado como elemento fundamental dessa frase: sem predicado não há frase. O segundo é a observação de que a mesma frase é composta de um núcleo regente, o nó central, que contém um processo, o pequeno drama descrito por Neves (2002: 105). É sobre esse “pequeno drama” contido em um logos que pretendemos chamar atenção quando o encontramos em uma sequência, possivelmente rítmica, destinada a atingir seu enunciatário via ações de eficiência. Transportando o sistema para as frases musicais e fílmicas, observamos a construção de estilos através de cadeias representativas de limites e extra-limites: os sobrecontrários e subcontrários. A cadeia de termos proposta por Zilberberg descreve os movimentos ascendentes e descendentes, podendo passar de limites, intitulados de recrudescimentos, maiores e menores. Resta-nos, ao que parece, estabelecer uma razão entre frases, musicais e fílmicas, pela combinação do estilo, seus pequenos dramas, o mito como metáfora descritiva de um evento proposto por Zilberberg (2011: 211). O mito referido é aculturado pelo enunciatário, tornando perceptíveis os elementos rítmicos, seus estilos, contínuos e rupturas. Os recrudescimentos serão um dos formadores de figuras de retórica, necessários para a argumentação fílmico/musical. Se ascendentes, formadores de uma possível hipérbole discursiva, serão concessivos, portanto, acontecimentos visíveis ao analista e estabilizador de um estilo. O outro formador de figuras de retórica serão as formas de repetição apresentadas pelas sequências e suas relações.

Podemos pressupor uma dupla exposição de conflitos, dramas, no percurso, um musical e outro fílmico, percebida sincreticamente pelos enunciatários que buscam adaptação através de seus conhecimentos e das expectativas criadas pelo ritmo. É uma 
busca pela estabilidade do saber: de um lado desenvolvido pelo desenrolar da cena, enunciada, e de outro pelo saber silencioso relacionado ao conhecimento do tipo de enunciação (ZINNA, 2008: 6), o mito. Esse meta-saber (idem) gera uma adaptação de isotopias pelo espectador senciente, comprovando a eficiência do discurso. A predicação musical influenciará a adaptação pela força regente que expande a significação do filme, produzindo as relações fílmico/musicais.

Sabendo da necessidade argumentativa que o discurso eficiente tem, nos perguntamos sobre as figuras retóricas que o relacionamento entre música e filme pode ocasionar. Será possível observar a relação retórica entre estes dois discursos? Em que ponto de vista poderá ser observado? As respostas surgem das tentativas de operações retóricas de Jacques Durand (1974) desenvolvidas como análise de anúncios publicitários observados por suas relações constituintes. Durand desenvolve uma teoria de análise sobre figuras retóricas admitindo a existência de uma visão direta do objeto e outra figurada, o que poderíamos relacionar com o real e sua imagem reproduzida ou a música acusmática. Descreve o "figural” como uma operação de transporte do real para a reprodução, reflexo da linguagem quando “o que é dito de maneira 'figurada' poderia ser dito de maneira direta” (idem: 20), portanto dentro de uma neutralidade. O que o autor aponta é para uma transgressão do sistema quando se utiliza uma figura retórica uma vez que essa contém um extra sentido (idem: 21-2). Assim, define a retórica como uma operação que parte de uma proposição simples em direção de uma formulação complexa, modificando elementos em duas instâncias: (i) as que operam por substituição de um significante por outro, como os casos de jogos de palavras, metáforas, metonímias, entre outros; (ii) e as que operam modificando as relações existentes, como as anáforas, elipses, suspensões, anacolutos, etc. Para a primeira, a substituição, Durand localiza a relação sintagmática, de caráter operatório; e a segunda, a modificação, posiciona-se na relação paradigmática e de caráter relacional (idem: 23). Zilberberg (2012: 62) utiliza dessa estratégia quando descreve os sintagmas reflexivos e transitivos: exerce a possibilidade de operações possíveis sobre termos. Tal como o operatório e o relacional, afim de localizar os acontecimentos e os exercícios. Dessa forma, o acontecimento, portanto concessivo, será transitivo e seus relacionados opostos serão exercícios, logo implicativos, e reflexivos. A fórmula provém de uma concepção inicial que descreve a dicotomia entre processo e sistema, aplicado na observação de relações: se analisadas as relações de conjunções, portanto "e...e”, será sintagmático, e assim processual; se analisadas as correlações disjuntivas, portanto 
“ou...ou”, será paradigmático (GREIMAS; COURTÉS, 1999: 324). Assim, o que sugere Durand é tratar o operatório como ação do processo e o relacional como ação do sistema, propondo as operações fundamentais ${ }^{30}$ de adjunção, supressão, substituições e troca (DURAND, 1974: 23-4). No mesmo raciocínio, indica para as relações contendo duas classificações: (i) no mesmo e do outro e (ii) similitude e a diferença. Descreve a escolha pelo paradigma, o relacional, abarcando as duas classificações: identidade, similaridade, oposição e diferença (ibidem). Se considerarmos os efeitos que a sobreposição da música sobre o filme proporcionará, devemos organizar uma tabela que relacione os itens do sintagma e do paradigma, porém com reservas. Partiremos do conceito de que, primeiramente, observamos frases que se relacionam por sua extensão, portanto em uma visão transfrástica do texto fílmico e musical, e em segundo lugar, observamos o relacionamento entre frases musicais e fílmicas. A primeira ação, a extensão da frase, permitirá a leitura dentro de uma cadeia Tensiva de termos, onde observaremos os recrudescimentos, e a segunda ação nos mostrará a fusão fílmico/musical. A proposta é observar apenas as construções sintagmáticas de adjunção e supressão relacionadas ao eixo paradigmático contendo a identidade e a diferença. Existe uma defesa para essa escolha: não serão possíveis as visadas sobre as substituições e trocas sintagmáticas em frases fílmicas e musicais sem que se esbarre na praticidade das escolhas de traços salientes e redundantes, material este de escolha desse trabalho. Causaríamos uma duplicidade de conceitos próximos, ou processos ambíguos. Na mesma defesa, a similaridade e a oposição seriam desnecessárias e esbarrariam na mesma classificação. A eliminação de tais termos pode atribuir maiores efeitos de significação nas escolhas das figuras de retórica. Nosso quadro ficaria da seguinte forma:

Figura 35 - Quadro Durand

\begin{tabular}{l|l|l} 
& adjunção & supressão \\
\hline identidade & hipérbole & elipse \\
diferença & rima & metáfora
\end{tabular}

\footnotetext{
${ }^{30}$ Durand descreve a escolha das operações fundamentais como retiradas das figuras clássicas da retórica no que tangenciam as figuras de diç̧ão: adjunção (prótese, paragoge), supressão de um som (aférese), substituições de um som por outro (diérese), repetição de um mesmo som (rima, assonância, etc) e intervenção de dois sons (metátese). P. 23.
} 
Poderemos assim observar as ações de adjunção e supressão e seus processos de relação de identidade e diferença em comparações entre sintagmas ou em relações fílmico musicais. Cada uma dessas figuras de retórica fílmico/musicais poderão ainda ter seus percursos avaliados, descrevendo relações entre estados de início e final. Se observarmos a vontade do enunciador de compor um discurso dentro do meta-saber de seu enunciatário, perceberemos essas figuras de retórica pelo relacionamento entre sintagmas ou entre meios fílmicos e musicais. O texto cinematográfico está composto pela ação de eficiência, portanto, que atravessa a metáfora e a hipotipóse descrita por Zilberberg (ZILBERBERG, 2011a: 208) e agora possível de ser analisado pelas cadeias de termos no percurso, assim como seus movimentos. Chegaremos ao entendimento de um discurso tal como Fiorin descreveu acima, como veículo que faz o enunciatário aceitar as informações. As adaptações pelo enunciatário dos conflitos fílmico/musicais são vistas na aceitação do discurso retórico: "valores sociais fazem que a língua tenha termos diferentes para designar o que tem comportamento excessivo, o que tem procedimento insuficiente e o que o tem na justa medida.” - (FIORIN, 2015: 103). Estes termos diferentes serão agora localizados dentro de uma figura de retórica de hipérbole, elipse, rima e metáfora.

\section{$\underline{3.3 .2 \text { - Estilo mítico }}$}

Na organização mais recente sobre a Semiótica Tensiva, Zilberberg indica o reconhecimento dos estilos como reação de um consciente coletivo, efeitos de um público aculturado. O estilo, a que o autor se refere, é consequência de um reconhecimento do que já é adquirido pelo público, transportado pelo conhecimento do mito. Para Zilberberg, o mito faz parte do processo que explica a intensificação do sentido e representa a garantia da superioridade da eficiência da comunicação. (2011: 209-11). Aqui, parece-nos, mostra o mito como pré-condição de execução de um discurso eficiente, que juntamente com a língua e com a retórica construirão o discurso, referenciado por ele como uma metáfora em grande escala. Para desenvolver um argumento sobre os conceitos de mito, recorreremos à observação de uma das matrizes do estudo sobre a retórica e tentaremos uma atualização sobre o mito na apreensão de um estilo.

Uma estrutura elementar da retórica, que permite o início de uma análise, é conhecida como lugar comum: o tópois. Essa figura é aliada da invenção, o inuentio latino traduzido por Fiorin como "busca”, “ação de encontrar” (2015: 94). Essa busca depende de 
um inventário, argumentos disponíveis e necessários para o uso da arte retórica: é a este argumento disponível que chamamos de tópois, isto é: lugares (ibidem). Sem a necessidade de nos alongarmos na descrição dos lugares dentro de um sistema, percebemos que, na música e no filme, a localização e a recursividade desses elementos farão a argumentação, isso é, um ritmo, além de seus formadores de expectativa, acontecimentos, etc. A repetição de elementos, sejam novos ao observador ou bem fixados na vivência dos mesmos, tornam-se, ou se tornarão, saliências percebidas. A ideia é semelhante à definição de isotopia utilizada pela Semiótica na descrição do Dicionário de Semiótica (GREIMAS, COUTÉS) que descreve a percepção pela repetição de categorias e permite a uniformidade do discurso; parciais ou globais, mas sempre repetições (1979: 245-8). A repetição é um traço da argumentação retórica, que juntamente com o local utilizado pelo inventio se organizará em dispositio, ou seja, o discurso retórico propriamente dito (ZILBERBERG, 2011: 224). Adiante, no mesmo Dicionário, a postura da recção reaparece quando descreve que a modalidade de um enunciado regente, sobreterminando outro enunciado, define um plano isotópico, hierarquizando-os. Isso indica a permissão de leitura de uma tópoi em muitos níveis, seja em pequenos fragmentos ou em sentenças, ou até em longas ocorrências realizadas e modalizadas.

Sendo o veículo de comunicação, como cremos, programado em direção a uma comunicação por manipulação, podemos comparar o ritmo com a ideia de dispositio, ou seja, a exposição da organização do inventio. Dessa forma, o discurso apresentado e percebido pelo dispositio tende à garantia da eficiência e, portanto, da mitologia (ZILBERBERG, 2011: 211). Como garantia da eficiência do discurso, a mitologia se pauta pela tríade que mostra a necessidade de observar esse discurso pela ação de uma gramática onde mito, retórica e língua se complementem. A língua é motivadora da eficiência pela garantida do sistema, sua repercussão e sua recepção. Com isso, transita entre o eficiente e o não-eficiente quando em ato. A retórica aparece como movimento que leva do não-eficiente até o eficiente, envolvendo a resposta direta do enunciatário. Este, “tem de se articular com o imaginário, a analogia e o afeto” (ZILBERBERG, 2011: 212) e declara sua relação com o mito que o transcende. Logo, o mito representa a garantia da eficiência por conter a esfera de entendimento do espectador. Esta tríade, quando ascende à gramática é considerada por Zilberberg como estilo (ibidem). A constatação de um estilo deve estar aliada à percepção de um tempo que auxiliará na exposição das repetições, além de mostrar o quão distantes estão os eventos entre si. A categoria tempo é necessária na fixação dos mitos, pois deixa claras as sequências e as repetições que aderem a este ou 
aquele estilo (LÉVI-STRAUSS, 2006: 172). O romance “tem sua origem na serialidade consecutiva à diminuição dos afastamentos diferenciais, decorre também de um progresso em complexidade da natureza lógica dos termos afastados.” (ibidem). Para Levi-Strauss, a oposição repetição/distanciamento participa do entendimento de uma narrativa, permitindo localizar seu estilo. Com isso, podemos concluir que o estilo representa a eficiência da comunicação, assim como o discurso persuasivo, participando da formação do ritmo, das escolhas das repetições, seus lugares e distâncias.

Podemos utilizar o conceito de estilo em formatos maiores e menores, tal como são percebidas as cadências musicais indicadoras de eventos. Ou ainda, podemos perceber os grandes estilos que são a característica da sequência ou obra completa. A forma sonata, estabilizada desde o período Barroco da música, é caracterizada por certa repetição ordenada de elementos musicais. Esse estilo transbordou seu espaço e seu tempo perpetuando-se como forma composicional até o final do Romantismo musical (SADIE, 1994: 337-8). Observa-se a aceitação de seu estilo, marcado pelas repetições, que não deixam de ser ações retóricas aceitas por um público aculturado desse mito, dessa eficiência.

\section{$\underline{3.3 .3-\text { A estrutural }}$}

A possibilidade de análise de um filme musicado com o encontro de seus elementos, sua predicação musical e suas figuras retóricas representativas fez emergir uma estrutura em níveis. O reconhecimento do sentido dado pelo filme musicado parte de relações abstratas até as condições complexas demostrando um caminho, semelhante a outros métodos de análise da semiótica. Floch descreve a necessidade dessa observação sobre os relacionamentos dentro de uma estrutura e suas complexificações, tornando possível a apreensão de camadas constituintes de sentido (2014: 24-5). Essas camadas são hierarquizadas, como descritas neste capítulo, e consolidam-se via operações motivadoras. Temos então um primeiro nível de reconhecimento de elementos fílmico/musicais, isotopias, que podemos chamar de nível básico; um segundo nível de constatação da recção e, portanto, da predicação, ou aqui denominada de nível predicativo; e por fim, um terceiro nível de reconhecimentos retóricos e designado de nível retórico. Embora distante do modelo do Percurso Gerativo do Sentido greimasiano, essa abordagem em níveis remete alguns de seus elementos como a descoberta de “diferentes diferenças” (idem: 25) no nível 
básico e a descoberta de performances no nível predicativo. Mesmo com essas aderências podemos intuir suas distâncias epistêmicas pela observação de suas aplicações. Assim, esta análise em três níveis destinada ao reconhecimento de elementos fílmico/musicais e suas figuras de retórica tende a complementar outras análises, a de Greimas ou a de Zilberberg, que não declara seus níveis. Este último prefere a organização de uma análise pelo referencial estrutural e aponta a hipótese, formadora da teoria analítica juntamente com a dedução, como promotora das qualificações e das quantificações das relações. Assim, na ótica da Semiótica Tensiva, podemos indicar a leitura sobre os níveis que reconhecerão o sentido dessa forma:

Figura 36 - Quadro de Níveis

\begin{tabular}{|c|c|c|}
\hline Nível Básico & Nível Predicativo $\rightarrow$ & Nível retórico \\
\hline Quantifica o objeto & Qualifica a relação & $\begin{array}{l}\text { Quantifica e Qualifica } \\
\text { o discurso }\end{array}$ \\
\hline
\end{tabular}

Se aplicado em análise, os níveis demonstrarão dinâmicas de sentidos, que podem demonstrar uma dinâmica de transmissão de afetos, gerados pela vontade do enunciador e projetados para a veiculação em um meio de comunicação de massa. A descoberta de tal dinâmica confirma uma das abordagens sobre as paixões, descrita por Aristóteles no desenvolvimento da retórica: o pathos está ligado à qualidade do discurso (DITCHE, FONTANILLE, et al, 2005: 6). Na verdade, na divisão de Platão, utilizada posteriormente por Aristóteles, o discurso é formado de logos, o discurso em si e de pathos, a qualidade desse discurso (ibidem). Esta distribuição é citada nas finalidades de comover que descrevem a paixão, não como elas são, mas como "se acredita que elas sejam" (BARTHES, 2001: 77). Aristóteles "não as descreve cientificamente, mas procura os argumentos que se podem utilizar em função das ideias do público sobre as paixões” (ibidem), assim, as paixões são locais, isotopias ao nosso ver, representação dos afetos de quem ouve a retórica (idem: 78). Barthes aponta essa proposta de Aristóteles como extremamente inovadora, uma vez que promove uma "sociologia da cultura dita de massa" (2001: 78) e aponta as figuras passionais como o culturalmente estável dessa figura: “a cólera é o que toda gente pensa da cólera” (ibidem). A retórica qualificada pela paixão se distancia das análises redutoras, pois não busca a redução de uma alegoria por trás do que as pessoas dizem, mas, entende a paixão como “pedaços da linguagem já prontos que o orador deve simplesmente conhecer bem” (BARTHES, 2001: 79), ou ainda, qualificar o 
discurso. O discurso eficiente dotado de logos e pathos se estabelece como na Semiótica Tensiva, pela estrutura que visa a antecipação e não pela redução de elementos.

Composições musicais aliadas a composições fílmicas poderão conter elementos de classificações qualitativas que as determinem. Em uma publicação da Berklee University conhecida como Complete Guide to Film Scoring, a classificação feita deriva da qualidade de efeitos de sentidos observados em seus públicos, em anos de experiências cinematográficas e o reflexo em seus enunciatários. Assim como um orador que conhece seu auditório, esse guia de filmes da Berklee indica funções fílmico/musicais divididas em três grupos: funções físicas, funções psicológicas e funções técnicas. As funções físicas descrevem as relações entre música e filme que se colocam como ações físicas ou espaciais das cenas, como as músicas que definem os locais, as que definem o período de tempo, as intensidades de ação e as ações musicais que andam pari-passo com as cenas, as chamadas michey-mousing. As funções psicológicas são as músicas que dão assistência emocional, adicionando dimensões expressivas às cenas: são as músicas de criação de humores psicológicos, os reveladores de sentimentos, os reveladores de implicações e os reveladores de verdades. As funções técnicas ajudam na estrutura geral do filme, são as músicas que dão sentido de continuidade entre cenas ou continuidade de todo o filme (DAVIS, 2010: 139-143). Dessa forma, percebemos as qualidades desses discursos musicais relacionados às cenas:

Figura 37 - Quadro de Funções fímico/musicais

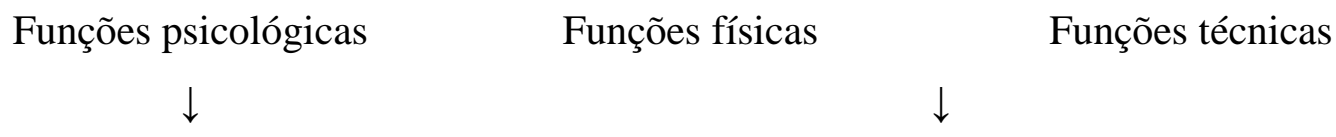

Descrevem as relações passionais;

Descrevem as relações espaço/temporais;

Observada dessa forma, a designação acima demonstra um possível desdobramento para a análise do nível predicativo, pois administra a qualidade, além de perceber a relação da música predicadora das cenas. A abordagem demonstra também o uso específico do estilo, destinado a apreensão de seus enunciatários. Percebemos a relação entre a dinâmica de transmissão de afetos, ação do cinema musicado, com o sistema culturalmente condicionado de expectativas descrito por Meyer. 
Resta-nos agora a aplicação de tais argumentos em uma análise fílmica escolhida. A saber, analisaremos a cena do "batismo" do filme O poderoso Chefão, de 1972 e dirigido por Francis Ford Copolla. A análise dessa cena será possível graças aos conceitos aqui percebidos. Passemos ao evento. 
Capítulo 4:

A análise 


\section{A análise}

Existem dois tipos de música: a música de sons e a música de luz que nada mais é que o cinema; e esta é a mais alta na escala de vibrações.

Abel Gance $^{31}$

Analisar a música predicadora de sentidos no cinema, via Semiótica Tensiva, significa observar as dependências mútuas descritas por Hjelmslev (2009: 28), ou seja, as ligações percebidas entre partes e estas com o todo (idem: 34). No desenvolvimento da Semiótica Tensiva, Zilberberg parece manter ampla relação com os conceitos de Hjelmslev sobre essas dependências, mais do que sobre o projeto das oposições diferenciadas de Saussure. As dependências aparecem no reconhecimento de eventos no espaço tensivo, afinal, falamos sobre dependências do eixo extensivo regido pelo eixo intensivo e, adiante, se desenvolve no reconhecimento de acontecimentos e sua rítmica. Zilberberg indica a observação sobre o intervalo e a assimetria para compor o reconhecimento da dependência: (i) no intervalo, por observar os eventos na ocorrência de seus paradigmas, pede um termo posterior superior ao anterior, causando-lhe uma graduação, indicando uma tipologia de intervalos - valências, subvalências e cadeias; (ii) a assimetria percebe as desigualdades em medidas, modalizações e recções indicadoras de mudanças na ótica do evento, uma visada sobre o que é relativo a que e o que é dominante de que (ZILBERBERG, 2011: 38-9). Ainda sobre a assimetria, podemos dizer que: o que se relaciona, o faz pela dominação, regente ou regido, e esta ação de dominar ou ser dominado mantém o que se relaciona. Com a soma das dependências, portanto, teremos a visão da totalidade do analisado.

O conceito de dependência explica melhor a noção de relacionamento entre partes, sintagmas ou segmentos. Estes se relacionam por mostrarem dependências entre si e serão o ponto de encontro com o eixo estrutural da Semiótica Tensiva. As isotopias fílmico/musicais serão apreciadas pelas possibilidades de dependências, seja entre seus eixos, musicais e fílmicos, seja entre ambos, e ligadas ao sentido relacional estrutural.

\footnotetext{
31 "Il y a deux sortes de musique : la musique des sons et la musique de la lumière qui n'est autre que le cinéma ; et celle-ci est plus haute dans l'échelle des vibrations que celle-là." (GANCE, 1927: 83)
} 
Passaremos a certa localização do objeto de análise desse trabalho, à cena do Batismo do filme $O$ Poderoso Chefão ${ }^{32}$, de 1972, apresentando seus autores e os ideais estéticos que permearam a construção do filme e da cena.

\section{1 - Um filme poderoso}

A construção do filme $O$ Poderoso Chefão ${ }^{33}$ é parte da adaptação do livro homônimo de Mario Puzo ${ }^{34}$. O sucesso em vendas da novela, escrita em volumes, favoreceu a decisão da Paramount Studios de patrocinar a produção cinematográfica. A Paramont decidiu chamar Francis Ford Coppola ${ }^{35}$ para dirigir a adaptação por considerar alguns argumentos: em primeiro lugar, Coppola é ítalo-americano e por esse motivo teria maior convivência com o tema do livro; o segundo motivo refere-se ao prêmio que Coppola recebera da academia do Oscar, na categoria de melhor roteiro, por seu trabalho em Patton $^{36}$, de 1970, dirigido por Franklin J. Schaffner. Coppola dirigira outros filmes, mas foi sua habilidade como adaptador de roteiros que chamou a atenção do estúdio (DELORME, 2010: 17-9). Puzo, que trabalharia como roteirista em futuras produções cinematográficas, participou da adaptação e, ao contrário do que ocorre em muitas colaborações entre autores e diretores, a parceria foi muito produtiva. O conhecimento da cultura italiana aliada ao comportamento do cinema americano seria também o critério para a escolha do compositor das músicas: o italiano Nino Rota ${ }^{37}$ (MAXIMO, 2003a: 233). Rota já gozava de sólida carreira como compositor de música para cinema, em filmes italianos e norte-americanos, sendo sempre lembrado por seus trabalhos com o diretor Federico Fellini, de relevância indiscutível no cinema universal.

Ao que parece, o contexto que remonta à produção do filme, objeto de estudo desse trabalho, passa por estes três autores.

\footnotetext{
${ }^{32}$ CHEFÃO, 1972.

${ }^{33}$ Idem.

34 1920-1999

35 1939-

${ }^{36}$ Patton, rebelde ou herói, 1970.

37 1911-1979
} 


\subsection{1 - Puzo, Copolla e Rota}

A ficção que recebeu o título de The Godfather, ou seja, o "padrinho”, foi o quinto livro do autor Mário Puzo. Descendente de italianos, Puzo nasceu em Nova York e, após a Segunda Guerra Mundial, cursou a New School for Social Research e a Columbia University. ${ }^{38}$ Publicou seu primeiro conto, The Last Christmas, em 1950, em uma coletânea dedicada a novos escritores, ${ }^{39}$ mas o sucesso literário só viria com o quinto livro, The Godfather, de 1969, que manteve-se entre os mais vendidos nos EUA por seis meses, de setembro de 1969 até fevereiro de $1970,{ }^{40}$ o que credenciou seu nome e obra para o campo das produções cinematográficas. Puzo foi, além de escritor de ficções, roteirista e adaptador para o cinema de textos seus (como a trilogia de $O$ Poderoso Chefão I, II e III) e de outros autores: escreveu os roteiros de Terremoto, de 1974, Superman, de 1978, Superman II, de 1980, e Cristóvão Colombo: a aventura do descobrimento, de 1992. Seus livros seguintes mantêm o tema ligado à máfia de descendência italiana nos EUA, com exceção do último, póstumo, Os Bórgias, de 2001, que trata de outra forma a associação por interesse, mas dessa vez durante o período do Renascimento italiano.

Diante do sucesso financeiro do livro The Godfather, a Paramount Studios adquiriu os direitos autorais para a transformação do livro em filme. Para essa jornada, seria necessária a experiência de um diretor que já houvesse tratado uma adaptação de livro para o cinema e que tivesse alguma aproximação com o tema. Por ter ascendência italiana, conhecer regiões e costumes e por seu premiado trabalho de adaptação no filme Patton, além de sua experiência em direções e produção em filmes de menor orçamento, o nome de Francis Ford Coppola surgiu rapidamente. No entanto, quando o estúdio Paramount entrou em contato para convidá-lo para a direção do filme The Godfather, Coppola relutou em aceitar. Só o fez pela insistência de George Lucas, seu sócio na produtora American Zoetrope, que usou como argumento a dívida existente entre eles e o Warner Brother Studios, ocasionada pelo fracasso de bilheteria do filme que produziram anteriormente, o THX 1138, dirigido por Lucas (DELORME, 2010: 17; COPPOLA, 2016: 20). É provável que Coppola não tenha aceitado a princípio a

\footnotetext{
${ }^{38}$ Fonte: www.mariopuzo.com - acessado em 12/2016

${ }^{39}$ American Vanguard, de 1950, publicação da Cambridge Publishing Company, ligado à The New School for Social Research. pp. 176-188.

${ }^{40}$ Fonte: The New York Times Fiction Best Sellers -

https://en.wikipedia.org/wiki/The New York Times Fiction Best Sellers of 1969 -acessado em $12 / 2016$
} 
adaptação do romance de Puzo devido à tradição de filmes relacionados à máfia até então, com estilo agressivo, filmes de aventura, suspenses, explosões, dirigidos ao consumo de entretenimento rápido. Coppola queria vincular-se a filmes menos superficiais, com mais questões reflexivas. Ao aceitar a direção de The Godfather, Coppola iniciou seu processo de reescrita adaptativa do livro, contando com a ajuda do próprio autor, Mario Puzo (idem: 17-42).

Depois de quase ter o projeto rejeitado pelo diretor, o estúdio Paramount procurou interferir na continuidade da adaptação. As escolhas de Coppola para o tipo de cena, sempre escuras e sombrias, e de Marlon Brando para o papel de Don Corleone geraram dúvidas. Coppola já havia cooptado Brando para participar de outra produção sua, The Conversation, filme que realizou em seguida sem Brando, mas a convivência e o histórico do ator já haviam influenciado o diretor a considerá-lo a escolha adequada para o personagem de The Godfather. Para o estúdio, Brando era indisciplinado, com um histórico de passagens ruins que atrapalhavam as produções que participou. Além do tom sombrio das imagens e da escolha de Brando, a terceira antipatia do estúdio foi em relação à escolha do compositor das músicas do filme, Nino Rota, que ficara famoso na Itália compondo para os filmes de Federico Fellini. A Paramount só se convenceu quando Coppola mostrou o trabalho que Rota estava desenvolvendo para a cena, já filmada e editada, do assassinato na cantina italiana, protagonizada pelo ator Al Pacino.

Nino Rota já gozava de experiência e prestígio ligados ao cinema quando foi chamado pela produção de The Godfather. Fora professor de composição em Roma, na Academia de Sta. Cecília, desde 1956 até 1959, quando passou ao Liceu Musical de Bari, onde lecionou até os primeiros anos da década de 1970 (ROTA, 1993), mas foi como compositor de música para cinema que alcançou sucesso. Em 1933, fez sua primeira composição para cinema, atividade que exerceu até o ano de sua morte, em 1979. Rota já era conhecido no meio cinematográfico por seus trabalhos com Fellini, mas alcançou olhares internacionais ao compor músicas para O Leopardo, de 1963, dirigido por Luchino Viconti, Romeu e Julieta, de 1968, de Franco Zefirelli, e pelo sucesso internacional conquistado por Waterloo, de 1970, dirigido por Sergey Bondarchuk (VEGLIA, 2014: $68 \%{ }^{41}$ ). Sua educação musical foi erudita, proveniente do eixo central do romantismo italiano, de um lado por professores discípulos de Giuseppe Verdi e de outro pela convivência com músicos eruditos em seu núcleo familiar

\footnotetext{
${ }^{41}$ A notação gráfica [\%] refere-se à localização da citação em livro eletrônico Kindle que mostra a porcentagem de espaços percorridos e não a numeração convencional de páginas.
} 
(VEGLIA, 2014: 30-6\%). Com onze anos, em 1922, compôs seu primeiro oratório, $A$ infância de São João Batista, que foi recebido com entusiasmo pelo público. Sua precocidade e talento, além de uma carta de recomendação redigida pelo maestro Arturo Toscanini, o levaram a complementar os estudos de composição no Curtis Institute, da Universidade da Filadélfia, de 1930 a 1931. Em 1933, compôs a música do filme Treno Popolare, dirigido por Raffaelle Matarazzo. Foi a primeira de uma vasta produção com mais de cento e vinte músicas para cinema e TV. Compôs também mais de trinta e quatro músicas do repertório erudito e instrumental; cinquenta músicas vocais e para coral; trinta e seis músicas dirigidas ao palco, como óperas, balés e teatro e quarenta e nove composições para conjuntos de câmara. ${ }^{42}$

Sua produção, ainda que contínua e criativa, recebeu diversas críticas ligadas ao "reúso" de temas musicais, principalmente em música para cinema. Há casos que chegaram, inclusive, a gerar processos jurídicos e retiradas de indicações de prêmios. O caso mais comentado por seus biógrafos e documentaristas trata deste mesmo filme tema desta análise: O Poderoso Chefão, de 1972. O tema musical central, que apresenta o filme e depois é rearranjado como tema “de amor” do personagem Michael, já havia sido utilizado em Fortunella, um filme dirigido por Eduardo de Felippo em 1958. Ao perceber a reutilização do tema, a Academia do Oscar norte-americana retirou a indicação ao trabalho de Rota para o prêmio de Melhor Trilha Sonora Original. Nino Rota defendeu-se alegando que a composição era utilizada de maneiras diferentes: no filme italiano, é alegre e arranjada para banda marcial, enquanto que para o filme de Coppola a mesma música é arranjada para um conjunto orquestral e mantém um caráter mais lento e respeitoso (ROTA, 1993). Além disso, argumenta que o que de fato importa é como essa melodia se envolve com o filme e, segundo ele, se for perfeita, está decidido (idem).

O Poderoso Chefão teria, portanto, a marca de três elementos ítalo-americanos: sua criação, sua produção e sua música. Como descreve Coppola, o desenvolvimento social e as características capitalistas que envolviam os EUA no período descrito pelo filme, os anos do chamado pós-guerra, tem muita similaridade com os procedimentos e cultura da máfia (SCIANNAMEO, 2010: 18).

\footnotetext{
${ }^{42}$ Fonte: http://www.ninorota.com/ - acessado em 11/2016
} 


\subsection{2 - Mudanças conceituais no cinema}

Percebemos uma importante mudança estética em composições musicais para cinema que ocorre no mesmo período de produção do objeto de análise deste trabalho. Essa mudança ocorre em duas vias: uma, influenciada pelos experimentalismos europeus e americanos, ocasionando uma ruptura com a modalidade musical anterior; e a outra, influenciada pela popularização dos aparelhos de TV. A primeira é geradora de boa parte dessas mudanças e se fortalece no advento da segunda. A televisão confirma a necessidade aparente de transformação do cinema, estimulando a intromissão de novas formas de conceber significações e predicações através da música (DAVIS, 2010:4554). Até a década de 1960 o cinema ainda contava com orquestrações "românticas", derivadas da ideia de um filme ser uma evolução do palco que, por isso, necessitava de sonoridades densas. Isso é parcialmente abalado com o sucesso dos primeiros temas musicais para a televisão e as repetições temáticas atribuídas aos heróis, transformando a percepção do espectador e facilitando, de certo modo, seu poder de concentração. Mesmo que a tematização musical referencial já fosse aplicada em produções como $E$ o vento levou, de 1939, do compositor austríaco Max Steiner, no final dos anos 1960 e início de 1970 a tematização musical aparece com unidade musical (CHION, 2003: 93). Isso decorre de tentativas de uniões musicais e fílmicas que compusessem unidades realmente fílmico/musicais, diferente do que tenta Steiner e sua aproximação com as operas de Puccini, compondo uma variação de temas ligados ao enredo do filme (DAVIS, 2010: 31). As unidades musicais passariam a ter mais interferência na proposta sensorial do novo cinema, com mais desenvolvimento sonoro, com mais definição de imagens, cores e qualidades, além das possibilidades de novas narrativas propostas pelo estímulo conceitual dos anos sessenta nas artes. Todas as tentativas de unidades levaram aos procedimentos rituais do cinema (CHION, 2010: 103), características que podem ser vistas nas montagens das décadas de 60 e 70 que consideram os planos-sequências como partes definidas e construtoras de um todo, muitas vezes não dependendo da ordem cronológica da narrativa e formando grupos sensoriais tão específicos que chegam a ser quase fragmentos de uma religiosidade na comunicação (idem: 110). Na outra extremidade dos fatos transformadores, estão as novas produções para a TV e suas montagens musicais que misturam o jazz e o rock com experimentos de orquestras: "Mais uma vez, de um jeito ou de outro, a audiência se acostuma com o vocabulário da nova música” (DAVIS, 2010: 45). 
Em nossa pesquisa, o filme e a cena a serem analisados participam dessa mudança conceitual. O diretor Coppola descreve o procedimento ritual utilizado, afirmando que "cada cena deve ter um núcleo que será a raiz da cena, a razão pela qual a cena está na peça só é validada se você expressar esse núcleo (...) a audiência percebe o eixo tornando uma experiência para eles” (COPPOLA, 2016: 33).

\section{$\underline{4.2 \text { - O Batismo }}$}

A cena do Batismo no filme O Poderoso Chefão, de Francis Ford Coppola, foi escolhida como referência de análise neste trabalho por tratar de um episódio ritualístico dentro de uma narrativa que, aparentemente, não condiz com ambientes litúrgicos. Os efeitos de sentido expostos nesta cena são conflitantes em um primeiro momento, mas mostrarão ações em rupturas e repetições que farão uma composição maior com o contexto do filme. Além da escolha pelo caráter ritualístico, expressos em música e imagens, esta sequência foi escolhida também por conter referências cinematográficas e musicais importantes, que auxiliarão na explicação da análise. O referencial ritualístico da cena marca um paralelo com a mudança de estilo do cinema comentada acima, a proposta de conduzir uma narrativa em planos-sequência aparentemente autônomos, mas com elos mantenedores de um eixo. Essa constante ação de surpresas, que teve início no período do filme em questão, permanece como técnica de cinema até os dias atuais.

A novela escrita por Mário Puzo, adaptada para o cinema sob a direção de Coppola, trata da trajetória de Michael Corleone, o filho mais novo de uma família de mafiosos ítalo-americanos, que ascende ao posto de capo da máfia, compondo uma espécie de capítulo na sequência dinástica. Sob o manto de certas morais ligadas às convivências familiares e conceitos comerciais, o filme se desenrola através de ameaças e violências possivelmente capazes de justificar as tais morais familiares. A cena do Batismo ocorre em momentos finais do filme, composto como um dos importantes “pontos de virada”, os plot points utilizados em roteiros (FIELD, 2001: 96-111), e descreve uma dessas justificáveis violências que reconduzirão a família mafiosa à paz e à organização. Nesta sequência, a música tem um papel predicador significante, o que representa mais um fator de escolha da cena e que localiza, ao mesmo tempo em que descreve, traços indutores de percepções das alterações psicológicas. A música nesta 
cena, parte adaptada de composições existentes e parte composta por Nino Rota, é apresentada de maneira muito diferente do restante do filme, causando mais um ponto de virada. Dessa vez, a música reafirma a sensação de ruptura com a narrativa, o que também está ligado ao contexto geral do filme.

\subsection{1 - Reconhecimento das isotopias}

Na expectativa de identificar as isotopias e sua importância para a análise, tomaremos como ponto de partida uma seleção de informações fílmico/musicais e uma busca pelos primeiros elementos reconhecíveis. Vale destacar a existência, na cena analisada, de questões figurativas, portanto abstratas, dos eventos enunciados. O Batismo em si é carregado de uma série de significados, descrevendo o próprio ato, portanto o sacramento da purificação e iniciação do cristão, além de descrever algumas metáforas pertencentes ao enredo, à história dos Corleone. Podemos observar uma similaridade entre a purificação da família de Michael e a sua própria iniciação como capo da dinastia. Outra questão figurativa, no filme, é a temporalidade física do filme: Coppola argumenta que, embora a narrativa se desenvolva em um período de dez anos, de 1945 à 1955, o que é apresentado no filme descreve apenas uma passagem completa de estações (COPPOLA, 2016). Assim, o final do frio, representado pela cena árida do enterro de Don Vito indica um intermezzo para uma "primavera” figurativa de início de calor. Essa “primavera” é o Batismo e, dessa forma, uma recolocação do conceito de início. O filme se desenvolve sobre rituais: além do sepultamento e do Batismo, já mencionados, a narrativa filmada tem início com um casamento e, em um momento de virada do roteiro, apresenta outro casamento, talvez demonstrando algum tipo de "liturgia” comportamental. O texto original de Puzo também é marcado por essa característica e começa com um ritual, de outro tipo, no caso: um tribunal. A adaptação aproveita as escolhas de marcação narrativa de Puzo, culminando em uma metáfora religiosa: o Batismo representando o fim do frio bem como o início da administração da família mafiosa por um novo capo.

Outros elementos se destacam na cena do Batismo: as falas em latim, a música e os ruídos. Mesmo contendo a fala cerimonial do Batismo em latim, é bem possível observar a ligação do texto com o ritual e, em determinados momentos, perceber as ironias e as metáforas existentes nas trocas de cenas, que alternam o ritual cristão com a 
série de assassinatos. Destacamos que Coppola escolheu utilizar filmagens de ações reais no filme: um verdadeiro Batismo, o de sua filha Sophia Coppola; em uma igreja real, a antiga igreja de St. Patrick da rua Mulberry de Nova Iorque; e com um padre real, o Mons. Medaglia (SCIANNAMEO, 2010: 46\% posição 1827); mas, parece-nos que o real não suportaria a ficção, fazendo da edição uma ferramenta importante. O texto, após a edição, está incompleto e fora de ordem - veja o anexo I - não comprometendo o entendimento da metáfora uma vez que não se espera conhecedores específicos do latim e nem do ritual. Os cortes e a edição contribuem para a ideia de uma direção sonora preocupada com o ritmo e a metáfora da cena. Mesmo sem saber se o conteúdo do texto em latim está correto ou completo, sabemos que se trata de um ritual cristão de Batismo adequado ao tempo da cena. O som da fala em latim está fundido com o choro de uma criança, indicativamente da mesma que está sendo batizada, e fundido também com a música cerimonial do evento. Neste conjunto de adaptação podemos perceber as questões ligadas aos sons que estão dentro da narrativa e os que estão fora dela; a montagem intercala acontecimentos, provocando uma oscilação constante do que está dentro ou fora, ou ainda, do que é diegético e o que é não-diegético. Observando o contínuo da cena, percebemos os três elementos sonoros, órgão/fala/choro somados a outros sons de ruídos, estes terão variações de consonância e dissonância, no caso do órgão, além de variações de volume, e intensidade.

A proporção de tempo de exposição dos elementos também é um fator a ser considerado, visto que os intervalos entre ocorrências vão se encurtando ao passo que ocorre um adensamento de sons e volumes. Em uma observação técnica da cena, podemos perceber as seguintes variações: 


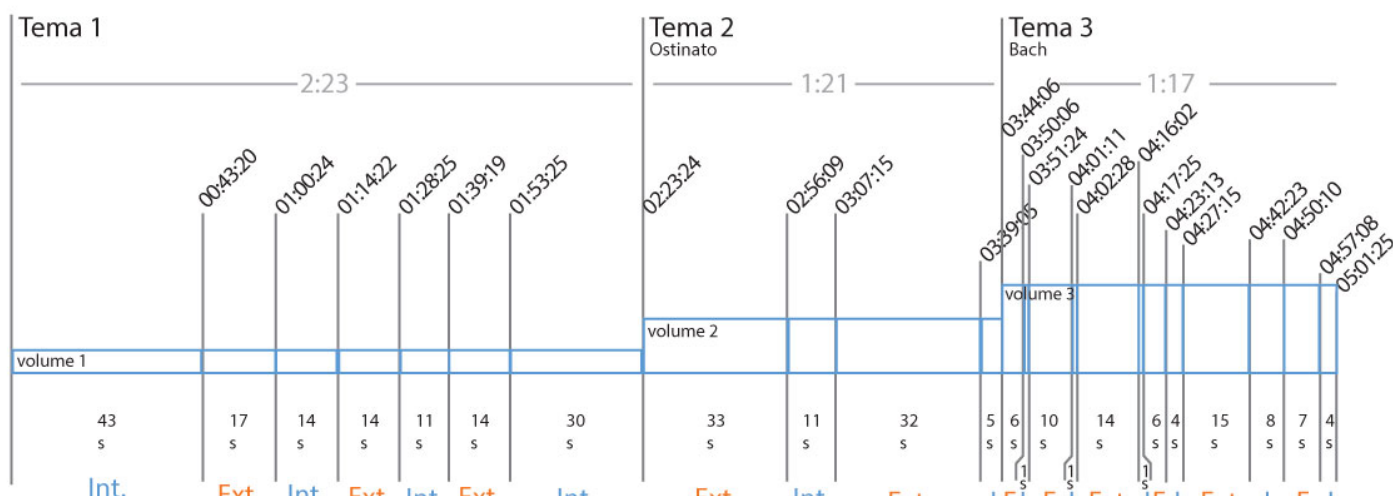

O gráfico mostra a estrutura da cena dividida em três partes, marcados pelos temas de órgão e suas durações. O volume aparece representado nas barras horizontais, indicando o aumento de intensidade em cada tema de órgão. Na parte de baixo, as três partes aparecem subdivididas pela alternância entre os acontecimentos internos e os externos (“Int.” e "Ext.”) representando de um lado a igreja junto ao rito e à família e do outro lado o desligamento desse contexto. Embora a soma dos tempos apresentados como interno e externo não sejam iguais, não representam muita diferença entre si. $\mathrm{O}$ que percebemos em um primeiro momento é um adensamento de cortes internoexternos em direção ao final da cena e, juntamente com esse adensamento, um aumento do volume dos sons. Vemos também uma maior exposição do primeiro tema, contendo quase o dobro de tempo da terceira parte. Assim, temos uma visão dos primeiros traços da cena capazes de indicar as primeiras relações tensivas.

No período do primeiro tema musical, há uma ralação direta entre a consonância musical ligada ao Batismo e a dissonância ligada aos crimes. Essas cenas de dissonância ligadas aos atos externos e de preparativos do crime são os significantes de conotação, ou seja, os traços salientes arbitrários: a música pode tomar diversos caminhos, mas esses traços de dissonância foram escolhidos para marcar a mudança de comportamento da cena. O significado de conotação fica claro quando percebemos a repetição do efeito dissonância/cena-externa. Assim, observamos a ação da música intensiva sobre a espacialidade extensiva das cenas internas e externas: 


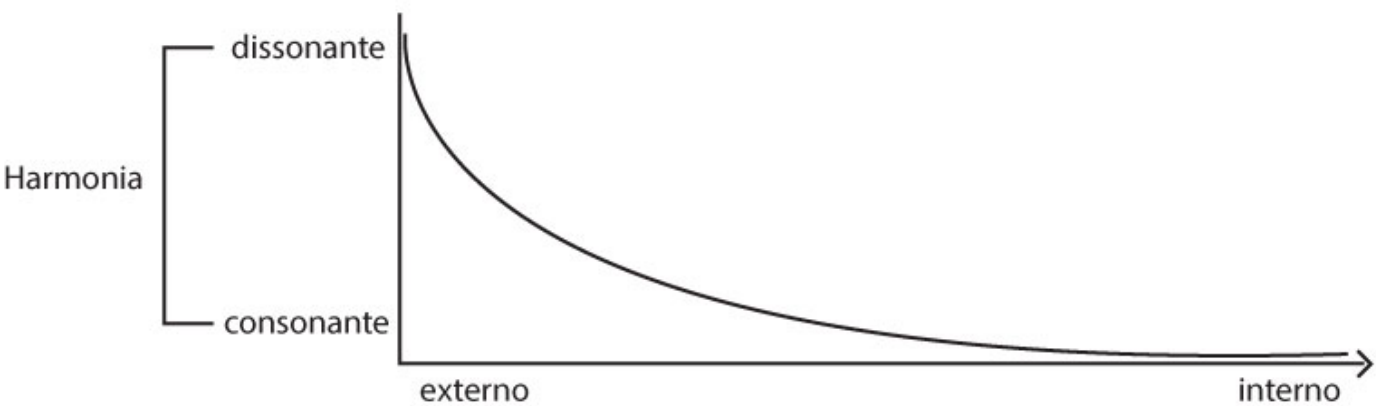

Esta primeira associação pode se aliar a outros eventos salientes, como as cenas de atos mafiosos da família, intercaladas com o Batismo, demonstrando a organização dos negócios, além da reordenação da paz familiar através dos crimes. É possível avaliar mais uma associação direta: os atos externos relacionados com os negócios da família em oposição ao ritual interno e a religião. Essas associações, por mais que representem significações semissimbólicas, estarão dispostas no eixo extensivo por se tratarem, como já vimos, de valores objetais. Resta-nos avaliar a dissonância e a consonância da harmonia musical no eixo intensivo como provocador do efeito de sensível.

Figura 40 - Gráfico Tensivo - Negócio/Família

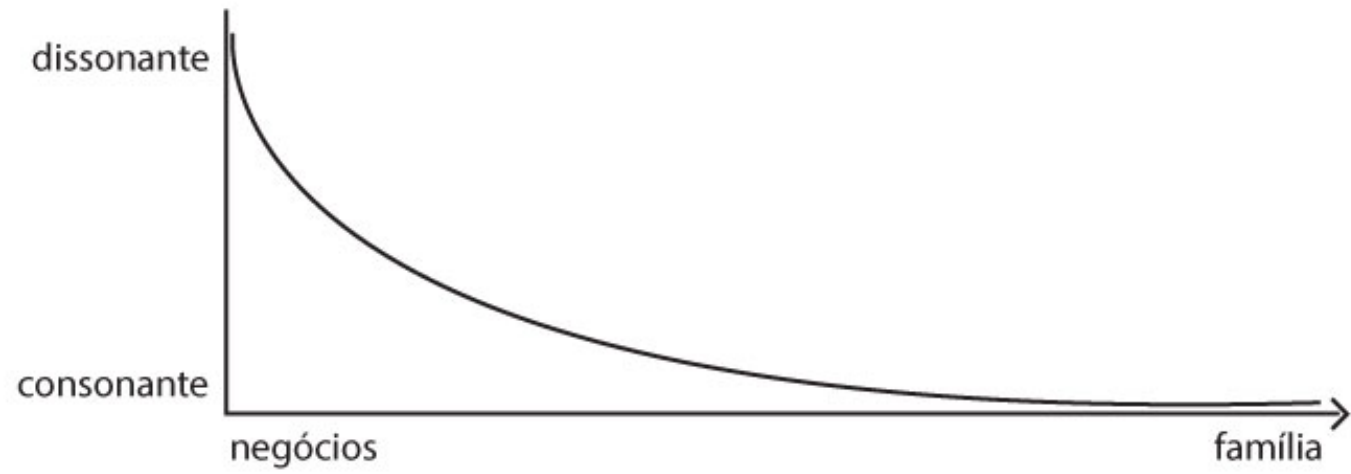

A área de maior concentração de objetos da extensidade encontra-se no lado esquerdo do gráfico, próximo ao eixo intensivo, relacionado aos negócios, aos preparativos e aos crimes da cena; a área de menor concentração, área difusa do eixo extensivo, encontra-se à direita e longe do eixo intensivo e está relacionada à família. No entanto, a narrativa mostra que, embora em oposição, família e negócios são parte de uma ação rotineira, um fazer permanente que envolve a proteção da família através 
de negócios e crimes. Na cena do Batismo, esse negócio familiar “atravessa as paredes” do templo, mostrando-o como um grande ritual e confirmando-o como o fazer criminal dessa família. Dessa forma podemos relacionar a operação ritual com os aspectos da harmonia:

Figura 41 - Quadro Ritual/Harmonia

\begin{tabular}{|c|l|l|l|}
\cline { 3 - 4 } \multicolumn{2}{c|}{ Ritual } & Negócio & Família \\
\cline { 2 - 4 } Harmonia & Dissonante & Acontecimento & Expectativa \\
\cline { 2 - 4 } & Consonante & Resolução & Exercício \\
\cline { 2 - 4 } & &
\end{tabular}

No primeiro tema musical existe uma relação entre a dissonância e o negócio e uma relação entre a consonância e a família. Este tema aparece como fixador de uma ideia que prepara o acontecimento, concessivo, intercalado com os implicativos exercícios da família consonante. Mas essa exposição tem uma mudança com o segundo tema, o ostinato ${ }^{43}$, progressivo e dissonante, que mostra a curva inversa no gráfico, possivelmente um efeito utilizado propositalmente, que vincula a dissonância à família e negócios. O ostinato permanece até a entrada do terceiro tema.

\footnotetext{
${ }^{43}$ Ostinato: termo que se refere a repetições de um padrão musical, podendo ser melódico ou rítmico, ou ainda, em cadências harmônicas ou melodias. (SADIE, 1994: 687); (DOURADO, 2008: 239).
} 

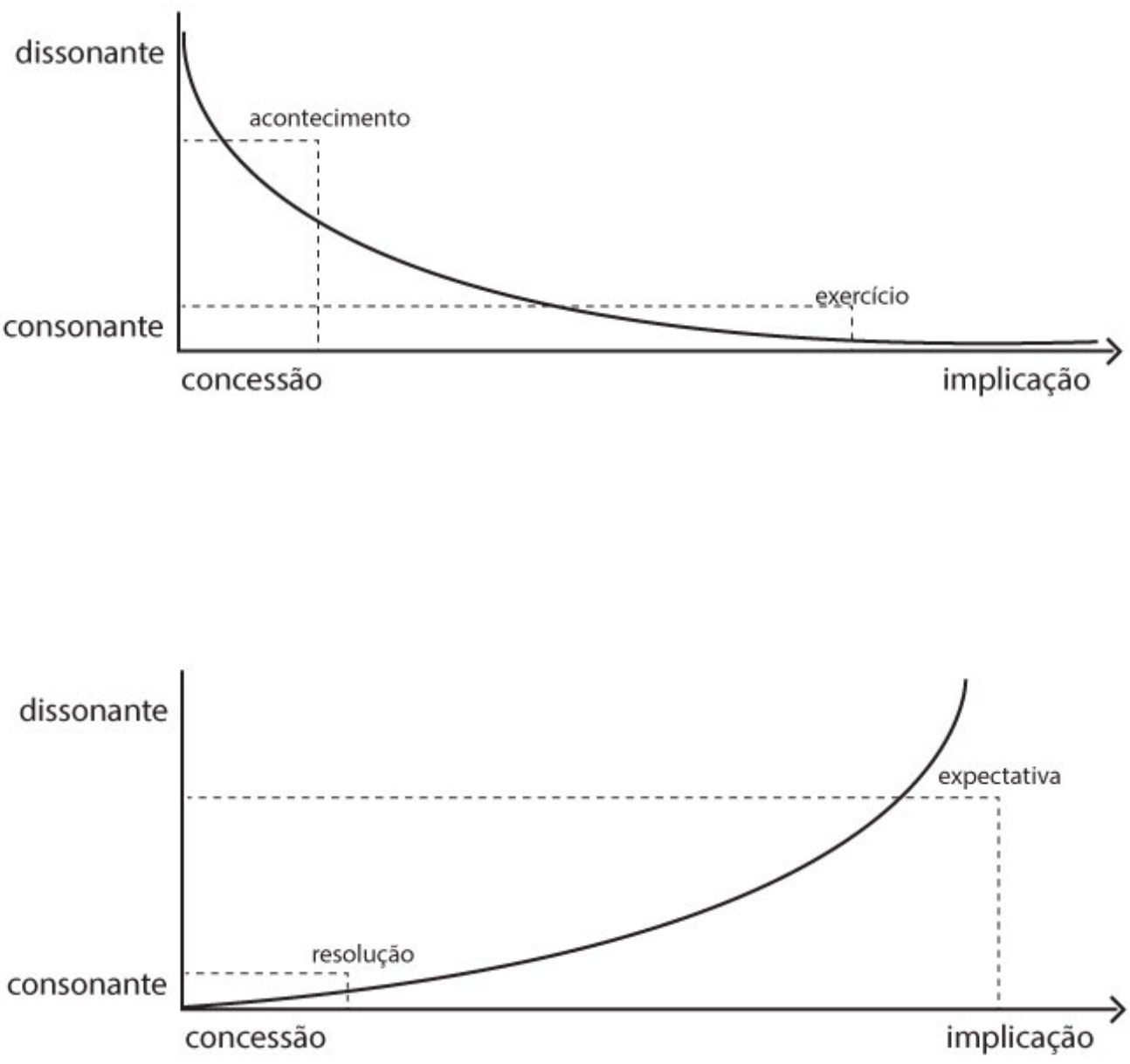

A inversão da curva parece ser um recurso de geração de expectativa provocado pela mudança musical. Esta expectativa só trará resolução com a entrada do terceiro tema, o Prelúdio de $\mathrm{Bach}^{44}$, que, embora apresente movimentos mais rápidos, distintos dos movimentos largos dos temas anteriores, é consonante, solucionando o "mistério" até agora sugerido e unindo os rituais de família e negócios.

Em um panorama geral, percebemos as ações da família e dos negócios sendo tratadas ao mesmo tempo, num mesmo sentido, no mesmo ritual. Esse recurso confirma, de maneira surpreendente que família e negócio são a mesma coisa, além de tornar surpreendente a descoberta desse sentimento pelo espectador que não considera, na maioria das vezes, a existência de famílias assim. Aqui encontramos a concessão que

${ }^{44}$ BWV 532. 
expõe o acontecimento maior da cena, apresentado após as cenas intercaladas da primeira sequência, isto é, do primeiro tema.

Figura 43 - Implicação/Concessão/Implicação

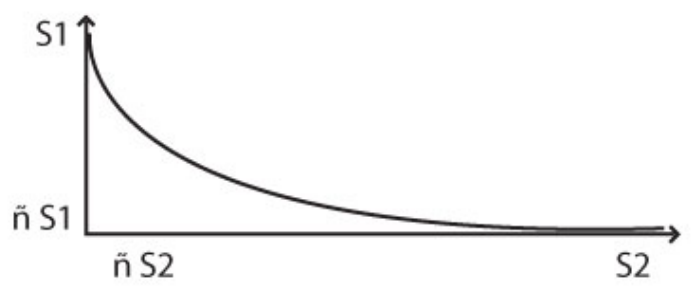

\begin{tabular}{|c|c|c|}
\hline dissonância $\Longrightarrow$ negócio & família $=$ negócio & família $\Longrightarrow$ consonânci \\
\hline Implicação & Concessão & Implicação \\
\hline $\begin{array}{l}\text { Preservação } \\
\text { dos negócios }\end{array}$ & $\begin{array}{l}\text { Mesmo tratando-se } \\
\text { de assuntos familiáres, } \\
\text { trata-se de negócios }\end{array}$ & $\begin{array}{l}\text { Preservação } \\
\text { da família }\end{array}$ \\
\hline
\end{tabular}

A exposição do primeiro tema tenta fixar um padrão implicativo, que é quebrado pela concessão do dúbio movimento familiar. O ápice da constatação do duplo ritual ocorre com Bach e as execuções, requerendo um repouso final apresentado pelas confirmações de Michael, o padrinho tanto da família como da criança no Batismo, diante de seus reais princípios.

Junto com a inversão da curva do campo de presença reside outro movimento formador de expectativas, o da aceleração de cortes, do aumento de volume dos temas e do choro da criança. Aqui a expectativa não está ligada à dissonância, mas ao empilhamento de sentidos geradores de ênfases. Quando Zilberberg demonstra a expansão dos termos relacionados a um evento, indica a possibilidade de movimentação sobre estes termos. A ação pode ser no sentido de aumento ou de diminuição, que possibilita, de um lado, a percepção de um sintagma transitivo, isto é, implicativo, e possível dentro da oposição dos termos abrir o fechado e fechar o aberto, ou, de outro lado, de um sintagma bizzarro, nos termos do autor, que sobreaciona os termos, dandolhes uma característica concessiva e reflexiva: abrir o aberto e fechar o fechado. Este sentido de reflexividade é encontrado na sequência do Batismo em sua sensação de aceleração. A aceleração dos cortes e o aumento do volume, assim como o choro 
contrapontístico, promovem o sentido de ênfase, tentando acender a uma hipérbole do sentido. Podemos elencar uma cadeia iniciada pela oposição dos termos fraco e forte, e representar a expansão dos termos com os sobrecontrários indicando o fraquíssimo e o fortíssimo. A cadeia de termos seria marcada assim:

\section{FRAQUÍSSIMO $\rightarrow$ FRACO $\rightarrow$ FORTE $\rightarrow$ FORTÍSSIMO}

A movimentação da cena do Batismo percorre essa dimensão do fraquíssimo - a cena distante do altar da igreja e o som do órgão consonante - até o máximo de fracionamento entre ocorrências, com volumes crescentes. Observando suas expressões, a cena toda é implicativa e obedece a uma curva conversa e constante.

Figura 44 - Gráfico Tensivo XI - Cadeia de Termos de Volumes

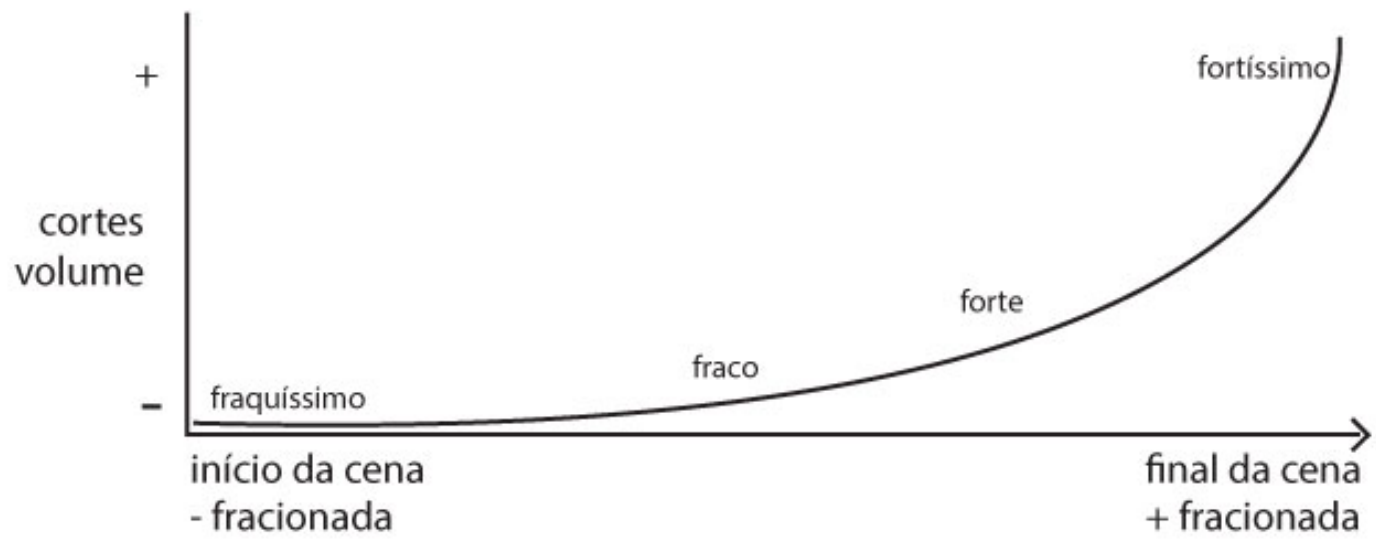

O final da cena do Batismo projeta uma hipérbole de repetições dinâmicas, capazes de promover a percepção das cumulações rítmicas e das profundidades alternadas da cena. O recrudescimento do forte é necessário para indicar reafirmações da narrativa, as arbitrariedades significantes de conotação que devem conter ênfase.

No caso da cena, o já conhecido perfil de chefe da família, o antigo cargo de Don Vito de dirigir os atos mafiosos para a manutenção dos negócios, é agora, via ênfase, indicados ao seu sucessor. O mesmo gráfico serve para mostrar a dinâmica de cenas mescladas à cena do Batismo. Desobedecendo a progressão do início até o final, ou seja, de aumentações regulares, o acontecimento das cenas intercaladas contendo preparações e assassinatos comportam-se como síncopes nessa sequência. São os saltos, de fraco para fortíssimo, por exemplo, que indicam o acontecimento, sobrevires, entre exercícios. Ao todo, parece-nos que são coleções de acontecimentos sincopados que farão a visão geral da cena, a expectativa e a surpresa. 
As isotopias musicais podem ser abordadas de duas maneiras: o universo de sentidos que a música de órgão, apresentada em uma igreja e assim compondo sua característica conotativa, remete ao uso e ao entendimento pelo público aculturado desse sentido; e as ações dos antecedentes/consequentes e suas possíveis variações. Embora a abordagem de um estilo musical pertença à fase analítica da predicação, podemos indicar, como isotopia, o reconhecimento da música de órgão como sendo litúrgica/tradicional e referenciada aos repertórios dos períodos Barroco ou Clássico. É interessante como o uso do órgão na igreja pode remeter a sua existência, ou não, dentro do templo, uma vez que dificilmente o instrumento fica visível, sendo este reservado ao coro da nave central. De qualquer forma, o instrumento e seu executor podem não ter sidos filmados, mas estão incorporados ao ideal de igreja. A harmonia executada no início da cena também remete ao repertório religioso, distanciando-se de obras do início do século XX que utilizaram o órgão com outra sonoridade e harmonia. Assim, a peça é daquela igreja e remete ao ato ali filmado.

\subsection{2 - Reconhecimento das predicações}

Tendo realizado a leitura dos traços reconhecíveis da cena, as isotopias, passamos ao reconhecimento das predicações. Aqui, procuraremos classificar os códigos e estilos que as isotopias indicaram, identificando relações reconhecíveis na composição fílmico/musical. Essas relações mostrarão a estrutura que envolve a cena, além de possibilitar o reconhecimento do ritmo e da profundidade. O nível da predicação pretende reconhecer também o conteúdo da narrativa, os papeis exercidos, assim como os códigos específicos e não específicos. Dessa forma, qualificamos as isotopias, isto é, passamos a reconhecer suas cargas tímicas através de suas posições tensivas e de suas movimentações modalizantes, identificando suas ações. Esse mesmo processo detecta o sujeito durante o Percurso Gerativo do Sentido: é via modalização que percebemos a imanência do sujeito da ação qualificando-o. Com isso, a percepção da música e do filme e seus conteúdos podem ser vistas como estruturas autônomas e participativas de uma totalidade.

A sonoridade do órgão dentro da igreja revela, como já citado, a utilização do instrumento no ritual litúrgico, o mais importante e culturalmente consagrado referencial musical de igrejas. Essa escolha, geradora de um código, é utilizada em sua máxima possibilidade, como demonstra a teoria, e declara o estilo do evento. 


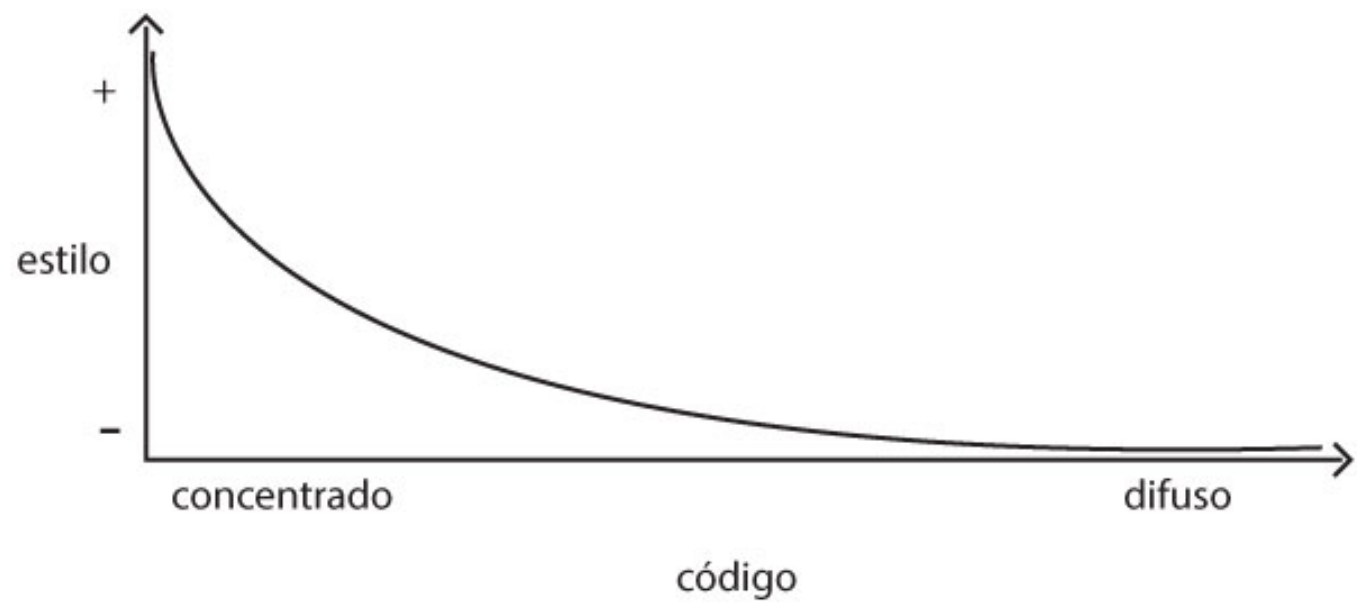

A concentração do código no início da cena mostra um estilo claro e reconhecível pelo enunciatário. Trata-se de uma escolha arbitrária pelo enunciador que descreve esse evento dessa forma, marcando a cena como “religiosa". Consequentemente, cada oscilação do código fará a redução do estilo, tornando o percurso propositalmente em oscilação. A cena filmada também demanda a observação de um estilo, pois, assim como a música, descreve no início da cena uma concentração do código religioso. Aqui temos uma sobreposição de estilos reconhecíveis que promovem um empilhamento de sentidos. O efeito é gerado pela concentração códica musical em recção com a concentração códica fílmica.

Figura 46 - Gráfico Tensivo XIII - Código/Estilo II

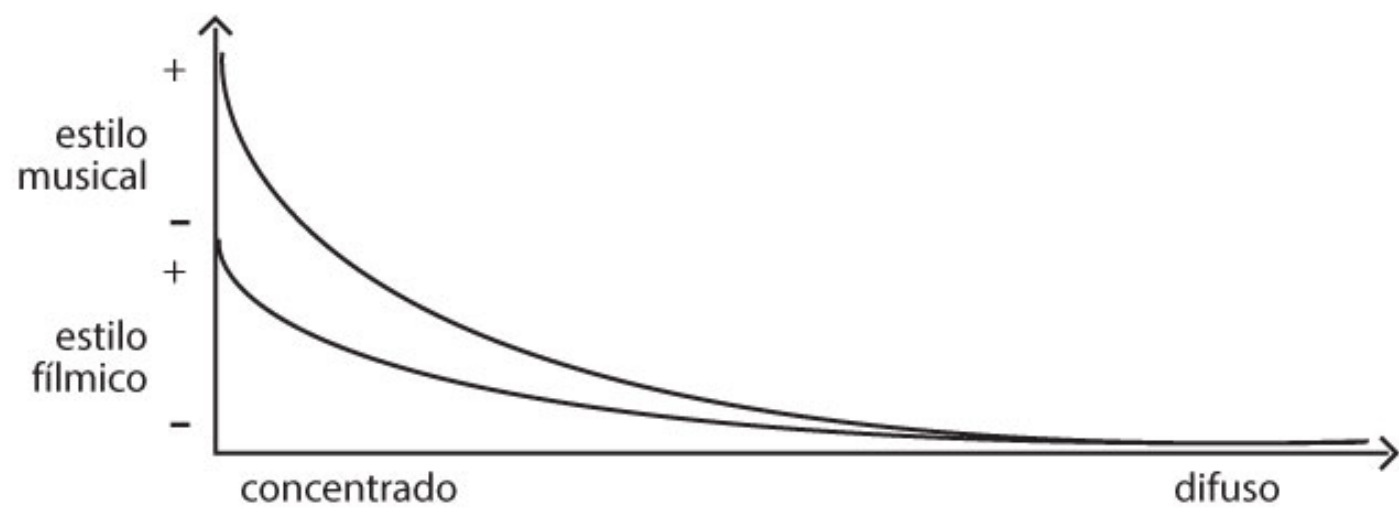

código

O gráfico acima mostra o “mais um de timia” observado pela predicação (ZILBERBERG, 2012: 29). As cargas tímicas intensivas podem ser aplicadas aqui pela 
constatação do empilhamento de códigos concentrados. Pela predicação é possível perceber o significado fílmico ser recoberto pelo evento musical, alterando seu núcleo de significado. As oscilações na harmonia são articuladas com os cortes de cenas externas ao Batismo, gerando uma combinação regular dessa predicação.

As organizações combinadas de estilos sobrepostos sofrerão variações no segundo tema musical. O segundo tema executado pelo órgão mostra um ostinato, que, em sua estrutura minimalista, repetitiva e dissonante, parece regular uma espera para atos futuros. Dessa forma, a composição musical, predicadora de sentidos, muda de estrutura, demonstrando dissonância em todos os espaços fílmicos, o interno da igreja e o externo das ações criminosas da família. Aqui ocorre a construção do ruído como fonte de expectativa e tentativa de melhora da informação. Na verdade, essa melhora está ligada à espera, gerando uma predicação pelo mais de carga tímica, mas agora pela diferença.

Figura 47 - - Gráfico Tensivo XIV - Código/Estilo III

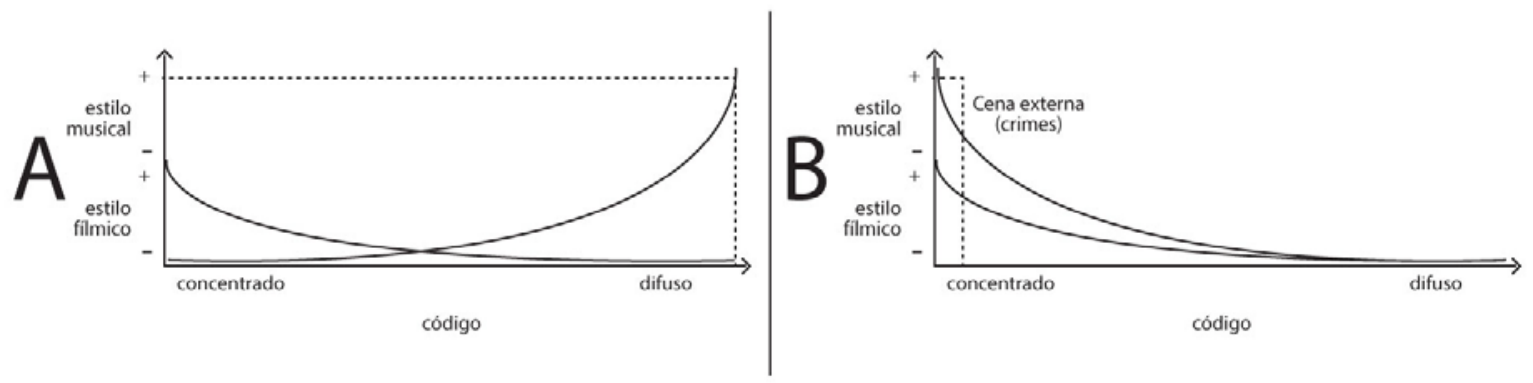

A oscilação entre as cenas internas e externas são marcadas pelas situações apresentadas nos gráficos A e B, que descrevem, respectivamente, a dissonância dentro da igreja e a mesma dissonância nas preparações aos crimes. A predicação de sentidos pela música continua sendo marcante por ser completamente oposta ao primeiro sistema. O efeito pode ser explicado pelo período de fixação da ideia inicial no primeiro tema e a completa ruptura conceitual no segundo. A sensação de espera só é percebida pela música que predica a cena, uma vez que as ações de cortes e conteúdos fílmicos não sugerem essa sensação. A terceira parte mostra uma nova abordagem, a de inverter a segunda parte. Agora a música é harmônica e acompanha a cena interna, mas não o faz com as externas. Na verdade, os elementos salientes que devemos observar não estão mais na harmonia, mas nas frases musicais e no volume.

A parte do Prelúdio de Bach apresentada no filme, o terceiro tema da cena, omite a primeira parte da peça, executando apenas a segunda em tonalidade menor. Dessa forma, assim como os cortes no texto do Batismo em latim geraram significantes 
cognitivos de sonoridade e articulação necessários para a cena, a secção na música de Bach foi feita com o propósito de manifestar a qualidade, em tonalidade menor, de um tema reconhecidamente vinculado à igreja. O segundo e o terceiro temas musicais são introduzidos após as perguntas e respostas em inglês, portanto reconhecível pelos enunciatários, e constituem uma ruptura no andamento em latim. São sobrevires que irrompem o contínuo duplamente, com a força do texto falado e do tema musical. Aqui, a predicação da música sobre o filme reafirma a mudança escolhida pelo enunciador. A melodia em tonalidade menor do terceiro tema é apresentada com repetições, formando um antecedente frasal, que será “solucionado” no consequente cadencial seguinte. Juntamente com essa resolução harmônica, nos é apresentada uma resolução da cena, mostrando os assassinatos concluídos. Tudo se resolve no filme e na música.

\subsubsection{1 - Profundidade e Ritmo}

A qualidade dos eventos ocorridos na cena do Batismo se apoia na postura da predicação. Ao observar essa característica, torna-se relevante buscar ocorrências ligadas ao fenômeno da profundidade e, posteriormente, ao fenômeno do ritmo. A profundidade permitirá uma verificação de distâncias entre termos da cadeia, indicando suas regularidades ou variações. Com o ritmo, será possível observar, também, a variações e regularidades pela ação de circularidades e linearidades. Assim, além do efeito de cumulação descrito por Zilberberg, teremos equipamento necessário para a análise do próximo nível, o das figuras de retórica (ZILBERBERG, 1996: 27).

Profundidade: percebemos relações diferentes dos vistos até aqui quando nos apoiamos no sentido da profundidade do percurso escolhido. Para Zilberberg, a profundidade é percebida quando ordenamos a valência da tonicidade no eixo da intensidade e a valência da espacialidade no eixo da extensidade. Dessa forma, teremos a visão sobre as maiores ou menores mudanças no espaço dentro do percurso filmado do Batismo, isto é: sendo o filme definidor de espaços e estabelecido no eixo extensivo, torna a profundidade critério das cenas visuais. A profundidade é dividida sobre três paradigmas espaciais, aberto/fechado, exterior/interior e repouso/movimento ${ }^{45}$, e nos permite separar as ações descritas no espaço e sugerir a análise. O que nos interessa nesse momento é (i) a utilização dos espaços fóricos, com as rupturas e ímpetos, e (ii)

\footnotetext{
${ }^{45}$ Portanto: paradigma do espaço diretivo das volições, paradigma do espaço demarcativo das posições e paradigma do espaço fórico dos ímpetos (elã).
} 
sua ligação com as cenas internas e externas, portanto, suas posições demarcadas. Assim, teremos uma leitura dos espaços demarcados aliados aos pervires. A relação entre os dois espaços marcam:

(a) As frequentes rupturas na continuidade da cena, e aqui podemos percebê-las tanto na quebra da continuidade do Batismo como na quebra a continuidade dos assassinatos, provocam a oscilação de estados fóricos no público e propõem uma progressão ascendente desses estados. A aceleração da frequência dos cortes está ligada às ocorrências dos eventos, ou seja, tempos maiores para as preparações e aproximações dos assassinos e tempos menores para os disparos e outros eventos ocorridos nas cenas. A relação de profundidade será da oposição entre o movimento e o repouso, por sua oscilação tônica, gerando a ligação entre as ocorrências das cenas. Portanto, observaremos a distância entre Batismo/assassinatos, avaliando uma graduação conceitual da cena: podemos tomar como exemplo os atos que ocorrem durante o Batismo, mas que não o concluem, ligados aos equipamentos pré-assassinatos, que também não são concludentes. Isso se torna útil na análise quando marcamos a ocorrência da profundidade como critério das distâncias entre termos da cadeia de subcontrários e sobrecontrários. Teremos uma oscilação de cortes vistos pela profundidade dessa forma:

Figura 48 - Gráfico Tensivo XV - Movimento

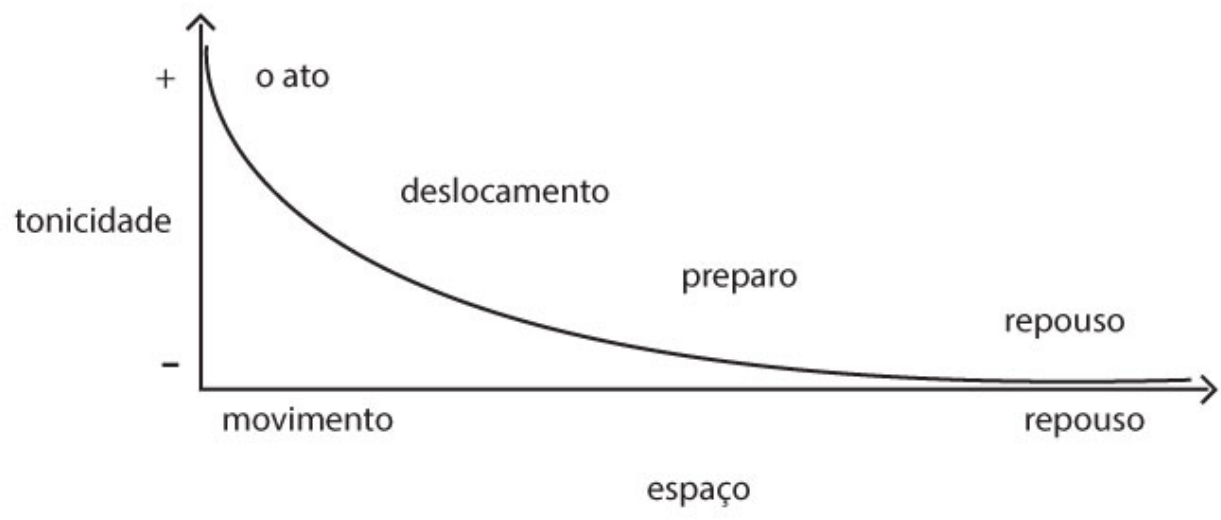

A utilização dos cortes ligados a ações fica clara pela análise da profundidade quando mostra o movimento de maior tonicidade ligado ao maior número de cortes e suas ações finais, ou seja, da preparação até o ato de jogar a água do Batismo na cabeça da criança e da preparação das armas e acessos até as consumações das mortes. No que 
compete à distância entre termos, os cortes mantêm sua dinâmica crescente em conjunto, revelando a vontade de compor um aumento contínuo. Do repouso ao ato, em ambas as cenas são apresentadas ações similares, sem grandes saltos entre termos.

Na relação entre os espaços fóricos dos ímpetos e os espaços demarcativos das posições, vemos que estão em paralelo e remetem dois elementos espaciais para a mesma condição:

Figura 49 - Gráfico Tensivo XVI - Espaço Fórico

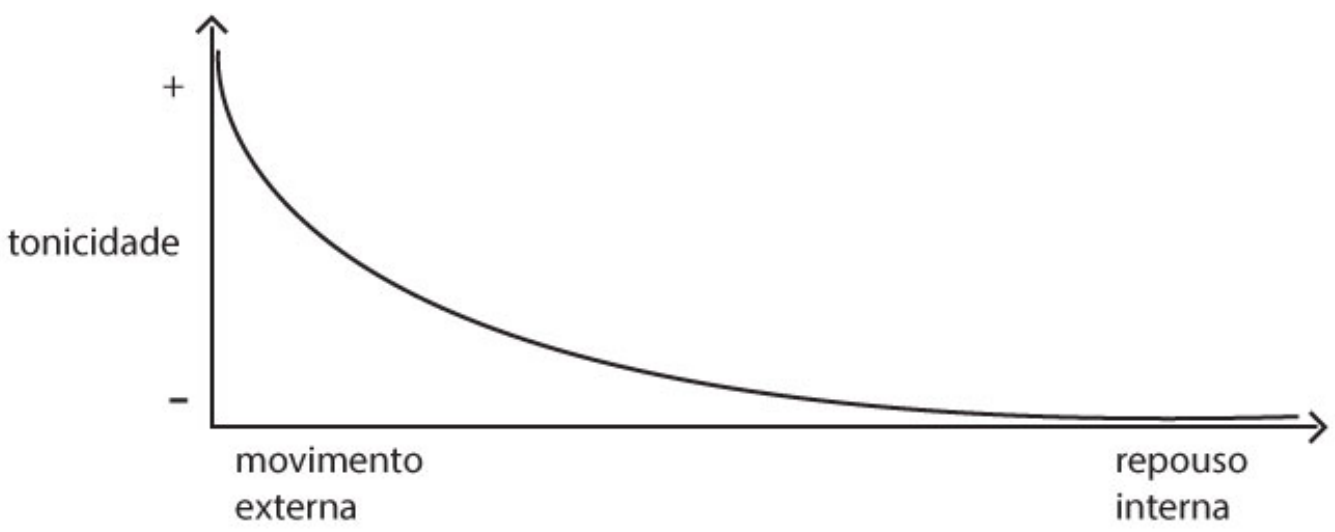

espaço

O contraste aparente entre a localização interna do Batismo e a localização externa das ruas e dos assassinatos está ligado aos repousos e movimentos dos mesmos cortes. Estes movimentos e repousos se referem a um conhecimento específico da atividade do cinema. Percebemos um aumento de cortes e planos dentro das cenas menores, ditas externas, do que nas cenas internas. Ou seja, as cenas da igreja/Batismo mantêm a câmera com menos movimento e em planos maiores, enquanto as cenas externas/assassinatos mantêm a câmera com mais movimento, maior número de cortes e variação entre planos abertos e fechados. Dessa forma, podemos verificar uma ação conjunta entre as cenas externas e movimentos específicos maiores e as cenas internas e movimentos específicos menores, isto é, mais próximos do repouso do gráfico.

Ritmo: sendo possível uma ótica sobre a temporalidade e o reconhecimento de ações tônicas e átonas, seremos capazes de perceber as demarcações e segmentações do ritmo. Poderemos, nessa observação do ritmo, aliar tanto o enunciado musical como o enunciado fílmico, uma vez que ambos participam de uma distribuição temporal. A demarcação será promotora da variação entre as circularidades e as linearidades, enquanto que a segmentação permitirá a visão das graduações existentes no percurso fílmico/musical. Em análise, parece-nos que a cena do Batismo se refere ao que Zilberberg chamou de forma espiral (1996: 29). Além dessa percepção do ritmo, 
podemos também marcar as rupturas ocasionadas pelas trocas de cenas com o sobrevir da demarcação relacionando-os com o pervir da segmentação.

(a) Demarcação: a primeira questão a ser comparada é a similaridade existente na oscilação entre circularidade e linearidade com a proposta de organização musical mantendo o antecedente e o consequente como estruturas reconhecíveis. Essa dupla relação, circularidade/linearidade e antecedente/consequente, estão presentes na demarcação se pudermos separar os eventos fílmicos ou musicais com a mesma ocasião. Dessa maneira, os cortes fílmicos entre Batismo e assassinatos mantêm relações contínuas em seus próprios segmentos, ou seja, Batismo com Batismo e assassinatos com assassinatos, mas também estão relacionados entre si por participarem da mesma sequência temporal: assim como no exemplo de Eisenstein do início do terceiro capítulo. A insistência nos temas ali expostos tanto acrescentam uns aos outros como esperam por novos acréscimos. Isso mostra a relação antecedente/consequente, ou, na Semiótica Tensiva, o circular/linear. Esta abordagem é chamada por Zilberberg como forma espiral, pois reconhece a formação de complementos dos fragmentos anteriores e a necessidade do próximo fragmento (1996: 29). Além desse aspecto cíclico e linear, que antecede e soluciona a antecipação, e talvez distante da canção exemplificada por Zilberberg, observamos também o aumento das brevidades da forma espiral, gerando uma sensação de aceleração. Dentro da demarcação, se percebido o movimento ascendente, teremos a confirmação do recrudescimento da cadeia de termos e, assim, a confirmação da cumulação.

(b) Segmentação: em um plano geral da cena, a segmentação representa a duratividade descontínua do percurso, não processual, expondo os restabelecimentos fracionados do texto. Embora a cena contenha repetições regulares, estas estão em tempos e espaços diferentes, promovendo a visão de uma segmentação irregular, propícia ao efeito de expectativa.

(c) A relação entre estes aspectos, demarcativos e de segmentação, mostra a possibilidade da descoberta dos termos subcontrários e sobrecontrários relacionados ao ritmo, uma vez que a demarcação marcara os sobrecontrários e a segmentação os subcontrários. Sugerimos a ação temporal como ordenadora, partindo da oposição da segmentação, portanto expoente dos subcontrários: a oposição pode conter os termos regular e irregular. Como complemento da 
cadeia, os termos da demarcação e sobrecontrários podem expor seus extremos como ordenado, para regular, e desordenado, para irregular. Teríamos uma ação Tensiva dessa forma:

Figura 50 - Gráfico Demarcação/Segmentação

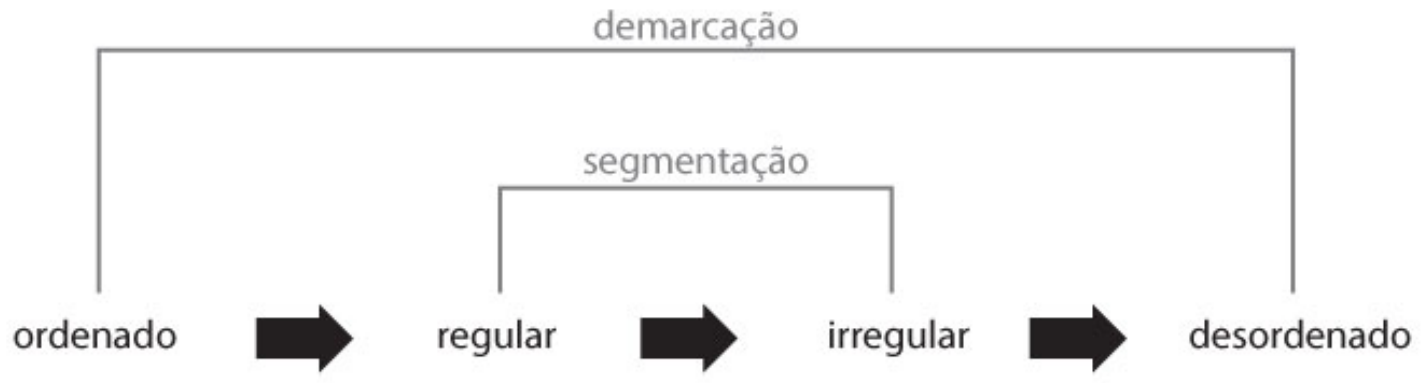

(d) Podemos elencar dois dos três paradigmas ligados ao ritmo. O paradigma do tempo demarcativo das posições está ligado à anterioridade e à posterioridade, logo, relaciona-se com a forma espiral que alia a circularidade e a linearidade como processo: o antecedente consequente musical. O paradigma do tempo fórico das extensões avalia a oposição entre duração e brevidade, podendo ser relacionado com os cortes cada vez mais breves da cena. Os paradigmas ligados ao ritmo mostrarão a temporalidade da cena analisada. Assim, teremos percepção das demarcações por seus posicionamentos e das forias por suas durações. Diante da cena, entendemos as demarcações do ordenado ao desordenado, em percurso e sem síncopas, assim como entendemos as forias que, embora seccionadas, compõem uma ação durativa, efeito dos cortes e do tema continuado.

(e) O ritmo musical da cena necessita de algumas observações à parte do compêndio avaliado até aqui. Considerando que a cena do Batismo contém três momentos musicais, ou seja, o primeiro improviso em movimento largo e com oscilações entre tonalidades consonantes e dissonantes, o segundo que apresenta um ostinato dissonante e o terceiro que executa o segundo movimento do Prelúdio de Bach em tonalidade menor, teremos uma predominância de aspectos demarcativos lineares, terminando com um fechamento cadencial do Prelúdio, portanto circular. A oscilação do primeiro tema parece-nos aliada à forma espiral, mas a permanência do segundo tema joga-nos na experiência linear de constante abertura. A ação parece indicar o paradigma do tempo fórico das 
extensões, deixando a experiência musical com extensões durativas em sua maioria.

A esperada sobremodalização, caracterizadora da predicação, fará sua exposição de complementação dos sentidos, somando afetos sobrepostos e hierarquizados. Podemos apontar a música como predicadora de sentidos uma vez que esta compõe as características sobrepostas aos significados das cenas fílmicas. O percurso geral da cena mostra uma modalização musical promotora de sentidos sobre a modalização do sujeito. Dessa forma, apreendemos, assim como o público, a parte fílmica regida pela música da cena, constatando a ação predicadora da música sobre o filme.

\subsection{3 - Reconhecimento das figuras de retórica}

Reconhecidas as isotopias principais do percurso fílmico/musical e seus efeitos via predicação, passamos ao reconhecimento das figuras de retórica componentes na cena. De início, e tendo percorrido os dois níveis anteriores, percebemos o efeito de cumulação como prática retórica principal do objeto analisado. As repetições, acelerações, amplificações e empilhamentos marcam o início desse reconhecimento que pretende expor os meios pelos quais a cena pretende alcançar sua eficiência discursiva. Devemos também reconhecer as metáforas estabelecidas no discurso fílmico/musical e, em seguida, perceber outras figuras disponíveis pela análise para o reconhecimento dos demais elementos que comporão a ação da retórica. A composição fílmico/musical da cena contém dois eixos de cumulação: (a) o que estabelece relacionamento com elementos componentes de um contínuo, como os temas musicais, os adensamentos ou o volume; e (b) o que estabelece relacionamento entre as expressões descritas no filme e as musicais, reconhecendo seus usos comuns e comparados a produções cinematográficas. Para a tarefa de reconhecimento de usos musicais em filmes, usaremos o Complete Guide to Film Scoring, da Berklee University, por conter uma classificação estável e reconhecidamente aplicada em estudos sobre a música de cinema. A escolha do Guia reflete a vontade de alinhar o presente estudo a outros de tema semelhante, podendo expandir a argumentação futura sobre os assuntos aqui tratados.

Observando as cumulações de elementos, que podemos chamar de cumulações de sintagmas relacionais, devemos iniciar com atenção aos cortes das cenas e sua insistência temática. A construção da ação dos assassinatos passa pelo estágio do preparo até a fase do ato, em paralelo com o preparo e o ato do Batismo. A sequência 
insiste no paralelismo para compor a analogia entre os dois atos que, pela aceleração promovida pelo espaçamento de cortes e pelo volume da música, reflete ser a parte mais importante da ação. De fato, é um momento marcante da narrativa, em que o sujeito da ação, Michael, toma a decisão suprema no controle dos negócios da família. Outras decisões fortes foram tomadas no decorrer da narrativa, mas essa, que elimina os chefes das outras famílias, está conceitualmente acima das demais. Vemos, portanto, o movimento crescente de ações ligadas ao sujeito Michael que marcam a cena do Batismo como um recrudescimento e promovem uma intensificação geradora em busca de uma hipérbole em torno do sujeito. A intensificação geradora é a tentativa de aperfeiçoamentos em direção à eficiência, uma harmonia nas ações entre a metáfora e a hipotipose somada à repetição: uma evidência do traço animado (ZILBERBERG, 2011a: 209). Na cena do Batismo, Michael é inquirido pela igreja durante a cerimônia. Cada sequência de perguntas é ironicamente aplicada em uma pausa musical e indica a troca dos temas. E para deixar ainda mais evidente o caráter mítico religioso dado à construção fílmico/musical da cena, há um tratamento de relação com a trindade: são três temas musicais em três perguntas que provocam as mudanças. O sintoma mais indicativo da vontade do enunciador em dar manutenção às triplas repetições aparece na alteração da peça original de J. S. Bach:

Figura 51 - Partitura Adaptação musical I
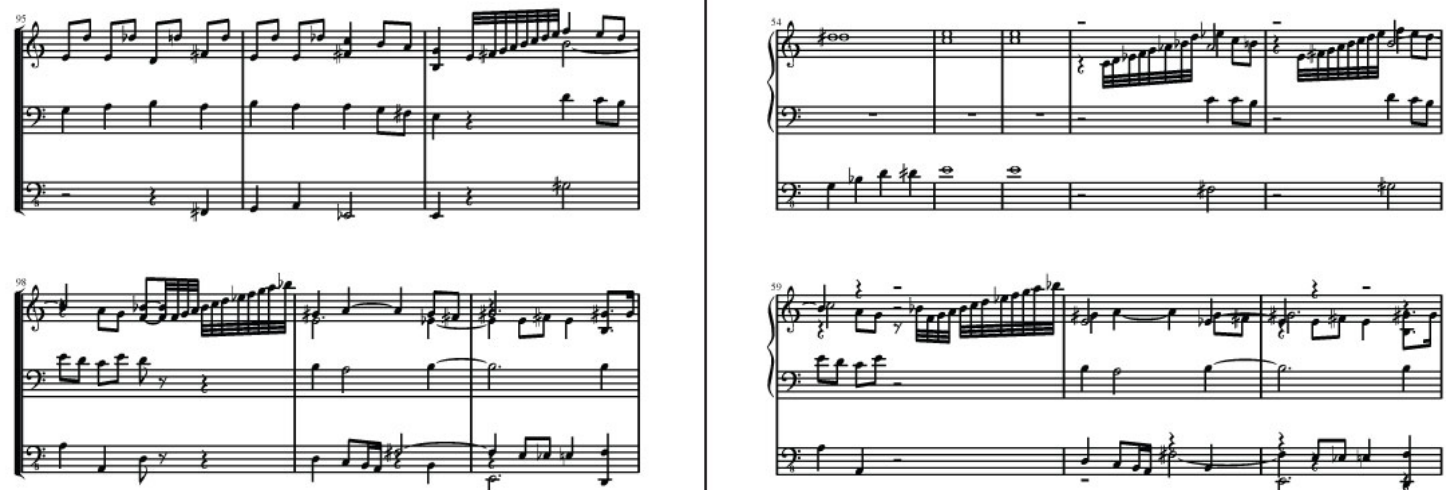

Prelúdio e Fuga em Ré maior, BWV 532 (Johan Sebastian Bach)

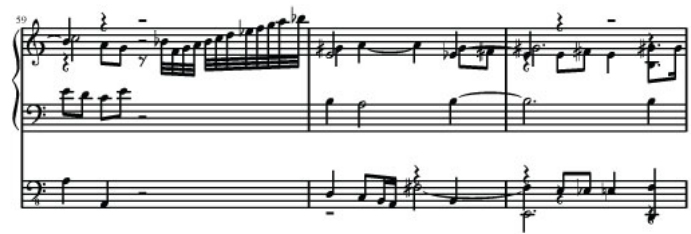

Alteração do tema de Bach por Nino Rota (transcrição musical nossa)

Na adaptação de Nino Rota, podemos observar que ocorre um acréscimo: os compassos 57, 58 e 59 possuem três “células” rítmica/musicais, enquanto que a peça original de Bach possui apenas duas, nos compassos 97 e 98. Percebemos a tentativa de ampliar a repetição para uma possível adequação ao filme, mantendo o código concentrado e o estilo tônico, induzindo o efeito cumulativo. Aqui, a cada pergunta do padre a Michael, 
portanto a cada mudança de tema, há uma modalização do sujeito, que passa de sujeito da espera para sujeito do fazer, mostrando também sua alteração de personalidade, que passa de defensor dos negócios da família para usurpador dos negócios das outras. Michael passa de suposto herói a vilão ganancioso em uma única cena.

Também a estrutura musical do segundo tema, o momento anterior ao "ataque” da célula rítmica/musical do Bach alterado, é composta em sequências de três eventos. Encontramos um ostinato grave, executado pelo baixo/pedal em sequência de três frases. Esse sistema é repetido quatro vezes:

Figura 52 - - Partitura Adaptação musical II

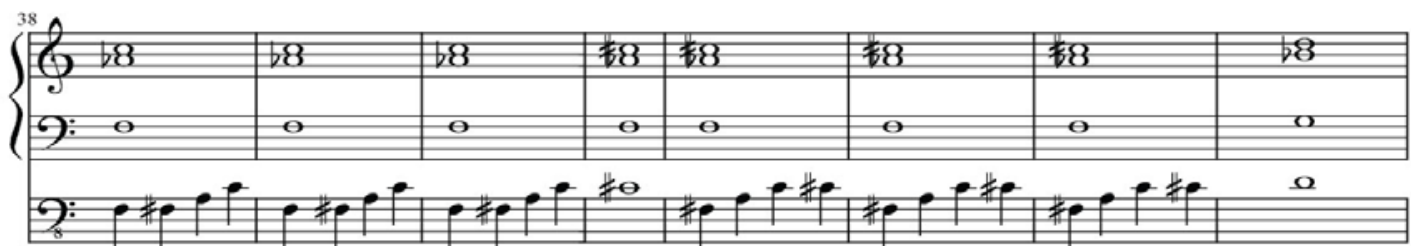

grupo 1
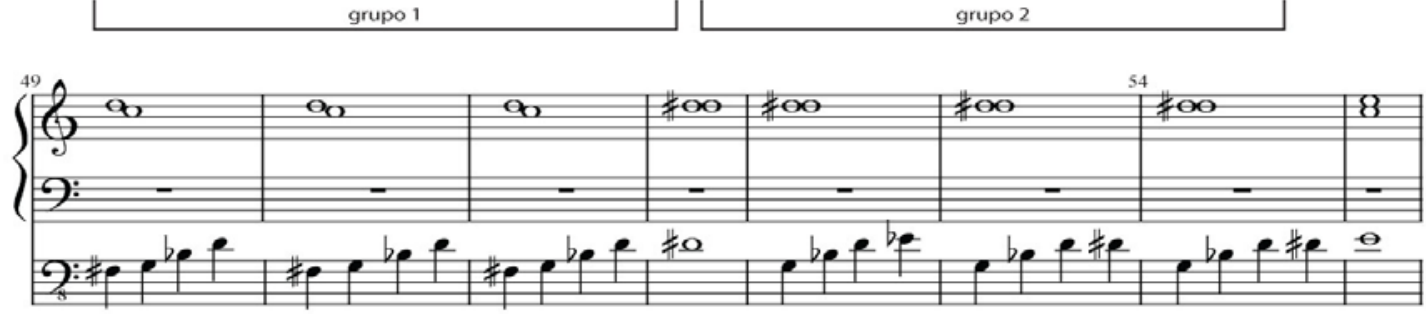

grupo 3

grupo 4

A repetição desse ostinato compõe uma área de espera, projetando uma sensação de expectativa preparatória dos atos seguintes. Essa "dilatação da espera" (ZILBERBERG, 2011a: 136) é característica da diferenciação entre suspense e surpresa descrita por Hitchcock (apud ZILBERBERG, ibidem). 


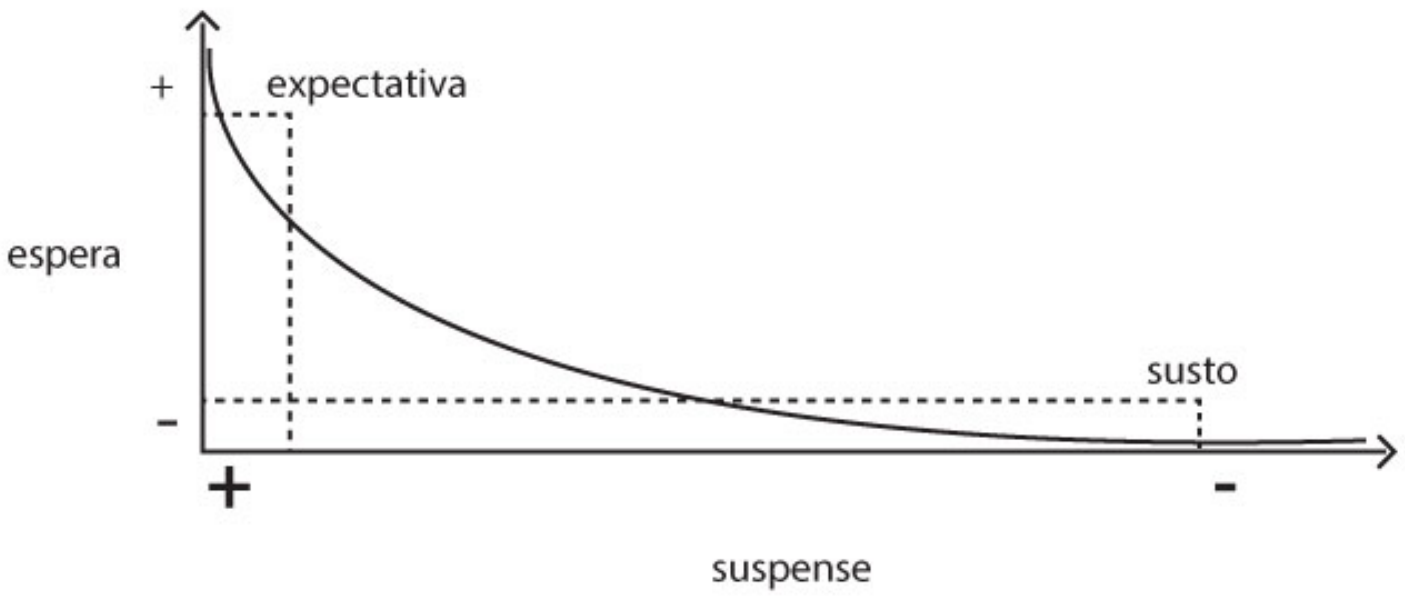

O recurso descrito por Zilberberg mostra a dilatação da espera como tonificadora do suspense patemizado para o público (ibidem). A cena do Batismo se desenvolve em uma curva inversa, criando expectativas para "solucioná-las" no breve percurso final. Embora a cena contenha uma sequência repetitiva de acontecimentos e exercícios, estes vistos de dois ângulos, expressando um contínuo, ela apresenta uma calma formação de expectativas e de concentrações códicas, indicando uma tonicidade do estilo, existente ou a ser confirmado. O estilo pode conter relações com o universo semântico do público, portanto existente, ou pode ser criado pela expectativa, uma vez que este estilo é a confirmação de uma consistência existencial, refletida pela aceitação do público que compreende a eficiência da comunicação e a toma como verdade. Esse efeito, o de dar validade a um traço arbitrário exposto em um meio de comunicação, é reconhecido na construção de narrativas como recurso retórico, persuasivo, que valoriza uma face do herói dando-lhe credibilidade a seus atos. O suspense patemizado que projeta uma expectativa e sua resolução aparece no percurso musical quando percebemos seus significados hipotéticos, portanto dentro da expectativa descrita por Meyer, e se tornará significado evidente junto às resoluções musicais (1956: 38).

Analisando a música da cena ${ }^{46}$, podemos avaliar o efeito da composição musical sobre o filme, percebendo duas funções abordadas no Guia da Berklee: a função física, que descreve a configuração do local da cena, sobrepondo sentidos às referencias visuais; e a função psicológica, que tenta descrever ações passionais da cena. Estas funções são apontadas como implicações dramáticas (DAVIS, 2010: 140) gerando efeito de cumulação. A música, composta para órgão, contribui com a referência

\footnotetext{
${ }^{46}$ Ver a partitura transcrita da cena no anexo II.
} 
religiosa do local, participando da função física. A cena, sem a música, já possui tal referência, ainda mais se considerada a fala em latim, mas o enunciador teve necessidade de construir um acréscimo de sentido à cena, compondo um mais um de carga tímica e, dessa forma, gerenciar uma sequência de acréscimos. A soma dos efeitos fica a cargo da função psicológica que tenta remeter efeitos pela execução dos tempos, volumes e tonalidades menores ou harmonias dissonantes. Temos uma ação de adjunção fílmica e musical, ordenada ora pela identidade de expressões fílmico/musicais, ou seja, cena fílmica de igreja com órgão de igreja, ora pelas diferenças de expressões, isto é, música de órgão e reconhecidamente de igreja com as cenas externas preparatórias de assassinatos. Assim, observamos uma oscilação entre hipérboles e rimas fílmico/musicais no início do percurso analisado.

Figura 54 - Quadro de Durand (Análise)

\begin{tabular}{l|l|l} 
& adjunção & supressão \\
\hline identidade & hipérbole & elipse \\
diferença & rima & metáfora
\end{tabular}

Em nossa análise, a hipérbole representa a figura de retórica que compõe a adjunção com a identidade, ou seja, da música litúrgica com a liturgia filmada. A diferença apresentada em cada corte nos dá o sentido de rima, uma vez que existe a adjunção da música de órgão com um rito continuado, porém sem a visualidade da igreja, passando ao lado irônico dos assuntos tratados em harmonia dissonante. Esta variação, entre hipérbole e rima, será constante nos dois temas iniciais, mas provocará outro sentido no terceiro tema musical, o do Prelúdio de Bach, quando apresenta uma supressão expressiva, mas com identidade entre filme e música, uma vez que participa da sequência de variações e do eixo narrativo. A elipse é considerada um efeito monista, ou seja, que "põe em jogo unicamente a relação de um elemento consigo mesmo" (DURAND, 1974: 41).

Se somados os efeitos da montagem fílmico/musical, observamos o segundo tema como o formador de expectativas e desenvolvedor do primeiro tema, um consequente do primeiro tema antecedente, ao mesmo tempo em que apresenta ostinatos dissonantes e cíclicos, preparador e tonificante do terceiro tema, expoente de ações e 
liturgias. Também o som do choro de nenê, embora acusmático e, portanto, gerador de expectativa, se comporta como um criador de ações: seu volume e sua presença são paulatinamente aumentados até o término do segundo tema ${ }^{47}$. Bem preparado, o terceiro tema é o conjunto dos volumes, dos cortes, das acelerações e dos contrapontos sonoros, indicando a intensificação de sentidos desejada pelo enunciador. Toda a cena contém um fluxo de adensamentos e acelerações capazes de gerar a pretendida intensificação de sentidos proposta pro Zilberberg. Na esfera retórica, a hipotipose se sobrepõe ante a metáfora, construindo uma eficiência discursiva. O estilo, com sua concentração códica, compõe uma estabilidade quando observamos seu percurso transitivo da desordem até a ordem. Essa ordem se torna importante na condução do filme inteiro, pois a cena do Batismo está fora da narrativa e sua organização a reintroduz no contínuo do filme. A cena seguinte a do Batismo pode ser considerada como um restabelecimento, um salto em síncope via repouso, por conter o término da música, o silêncio, a cena panorâmica e, mostrando à distância, em um dia claro, a catedral. Esse contraste fílmico/musical mostra o final da tragédia operística composta pelo Batismo. Uma pausa para os futuros acontecimentos do filme. Assim, passamos do “chegar a”, produtor de expectativas em um tempo/espaço ampliados, ao sobrevir eufórico das resoluções da cena, a hipotipose somada à metáfora, construtoras de uma eficiência discursiva. As cores da hipotipose seriam mais pálidas se a música não tivesse dado a elas a intensificação necessária, dosando o equilíbrio eficiente até a intensificação desejada pelo enunciador.

\footnotetext{
${ }^{47}$ Ver anexo III.
} 


\section{3 - A Tensividade do Batismo}

Wagner me matou! E. Chabrier $^{48}$

Se pudermos comparar o atual cinema aos conceitos ligados às óperas italianas, francesas e alemãs, veremos que a única coisa que perdurou foi a forma de construir uma tragédia. Desde a mudança estética ocorrida na década de 1970, o cinema, assim como grande parte das mídias audiovisuais contemporâneas, desenvolveu seu próprio meio de argumentação via exposições episódicas. Na música, tão condutora das ações operísticas, pouco deixou de comparação, uma vez que se adaptou criando padrões e ações combinadas com as cenas produzindo maior eficiência. Parece-nos que o ruído, aquele desdobrado pela teoria da informação que melhora a absorção da comunicação diferente do ruído-não-musical ou de cena, fez-se presente em harmonia composta musicalmente e exposto em repetições controladas. O resultado pertence aos meios de comunicação de massa, que também procuram a eficiência discursiva utilizando as figuras de retóricas possíveis. Na cena do Batismo, objeto de análise desse trabalho, observamos as cumulações influenciadas pela música, causadora de uma espera só resolvida com cadências. Desde o período Barroco as cadências estão ligadas aos momentos conclusivos em composições diversas e demonstram traços arbitrários localizadores de estilos. A cadência dita "perfeita” apresentada na composição musical ao final do terceiro tema da cena, está relacionada à outra cadência, uma fílmica que descreve a modalização do personagem Michael. Podemos brevemente relacionar o termo cadência musical à modalização semiótica, visto que ambas aderem a uma conformação de estilo, assim como descrevem uma mudança no percurso. Michael passa de sujeito da espera, portando de um não-ser-ainda e do não-fazer a sujeito da ação em um saber-ser e fazer, mas com a não esperada resolução de um saber secreto, que executa seus adversários (TATIT, 2010 :26). O percurso geral do filme indica que Michael fará uma reunião, mesmo sabendo da possível traição de um de seus aliados. A

\footnotetext{
${ }^{48}$ Alexis Emmanuel Chabrier (1841-1894): embora fosse funcionário do Ministério do Interior da França, foi editor musical, pianista e compositor de peças para palco, piano e pequenos conjuntos. Foi fortemente influenciado pela obra de Richard Wagner, chegando a pronunciar "Wagner m'a tué!" em uma carta em 23 de setembro de1881 ao seu editor Georges Costallat após ter assistido Tristão e Isolda. Declara, em carta, sua transformação pessoal ao perceber as ações musicais e cênicas que Wagner propunha. Chabrier foi um dos grandes influenciadores de Ravel e Debussy- (Paolacci, 2011: 203-11).
} 
resolução das mortes se torna uma surpresa, bem composta com o suspense dos preparativos e da dilatação da espera. Somos conduzidos a uma cadência de engano discursiva, reconhecida na música como cadência deceptiva ou interrompida ${ }^{49}$. A decepção que envolveria a decisão de Michael é percebida como vitória justificada pelo público, ação esta ocasionada pela espera e pelo não-deceptivo da cadência perfeita musical: a cadência musical confirma sua sobreposição diante da cadência fílmica. Temos assim, um tipo de indução trágica no cinema: a composição fílmico/musical acena para a música como definidora do conjunto, delegando a esta a formação dos estados de afetos a serem transmitidos ao público. Mesmo distante da ópera, o cinema permaneceu com a preocupação de enunciar uma dinâmica de transmissão de afetos em direção ao público, promotora da ênfase, de intensificações de sentidos cumulados pela música. A vontade dessa transmissão obedece a um sistema, inicialmente códico, que permite a variação entre o estilo e a expectativa de sua volta, permanecendo dentro de previsibilidades culturalmente estabelecidas: um mito. A armadura que o mito conduz existe em função de um objetivo (GREIMAS, 1972: 63): o da eficiência da transmissão, contemplando seu estilo e código, além da ação antecedentes/consequente, como na música. Claude Lévi-Strauss demonstra a relação entre mito e música quando aponta a dupla continuidade, uma, a que descreve a possibilidades de combinações de sons musicais aos elementos possíveis em um mito dentro de um universo social daquela sociedade; e outra, a que percebe a composição, musical ou mítica, de acordo com a capacidade de apreensão e memória do ouvinte (2010: 35). Adiante, mito e música voltam como composições discursivas próximas quando Lévi-Strauss descreve as distâncias entre termos significativos e seus maiores ou menores intervalos, reconhecendo, dessa forma, o estilo, local e época do mito (2006: 172). Em nossa análise percebemos a mítica enunciada a certa distância, através do rito que dela decorre. Ao que parece, os mitos regem os ritos, como o mito do sacramento efetuado por São João Batista reconhecendo o Cordeiro de Deus até a sua representação permanente na liturgia católica, ou ainda, do mito da manutenção dos negócios da família mafiosa até o rito de assassinatos em série.

Percebemos nas escolhas que descrevem este percurso analisado uma construção de significações induzidas, construídas pela apresentação, confirmação e reapresentação

\footnotetext{
${ }^{49}$ Arnold Schoenberg utiliza o termo Cadência Interrompida em Harmonia (2001 - UNESP) e Fundamentos da Composição Musical (2015 - EDUSP) - Cadência Deceptiva é o termo da tradução em inglês dessas mesmas obras.
} 
de caracteres fílmico/musicais. A inicial confrontação entre as figuras de hipérbole e rima até a forma elíptica de sua resolução descreve, respectivamente, as tentativas de fusão e confirmação: fusão entre o externo e o interno apresentado pelas rupturas e a confirmação da localização da família. A fusão está presente na aceleração fórica que será concluída na ênfase localizadora, efeitos descritos pela profundidade e pelo ritmo. Uma indução direcionada às tentativas de fusão pode ser percebida pela insistente repetição desse constante descontínuo, indicado pela dissonância. A polifonia dissonante descreve uma aproximação das notas aparentemente à força, condição esta possível de comparação com a mesma indução à força dos conteúdos internos e externos. A resolução aparece na escala em graus conjuntos, em escala, e não mais o cluster $^{50}$ dissonante. O contraste que percebemos está marcado na harmonia e na construção frasal da música, e em paralelo com a cena fílmica: a organização em escala da música confirma a organização harmônica e faz referência a "sapiência” de Michael. A música organizada de Bach sobrepõe a desorganização dissonante das rupturas, caminhando para a organização. Mesmo que outra peça de Bach tenha sua citação na mesma cena ${ }^{51}$, o Prelúdio alterado mostrado no terceiro tema entra como organizador, assim como referente de um saber, pelo público, do verdadeiro plano de Michael. Aqui podemos descrever a oposição natureza/cultura como referência da cena, pois além da descoberta do saber de Michael, encontramos a cultura como ocasião irreversível sobre a natureza, sobre o consciente e, principalmente, em estado controlador (LÉVISTRAUSS, 2010: 321-3). A escala do terceiro tema representa a cultura com a possibilidade organizada da harmonia regente das relações familiares e comerciais. A narrativa trata de uma cultura harmônica e consonante promotora de ligações, organizada sobre a natureza dissonante das colisões. A hipótese que classifica o mito como antecipador da ciência, por sua tentativa de superar as dificuldades naturais pelo entendimento (DUARTE, 2004: 29) leva ao reconhecimento da transmissão das mitologias pelo fluxo das repetições. A tentativa é de superar a natureza pela ciência, “opositora” da religião que se mantêm por outros mitos. Alguns rituais, como o do batismo, provenientes de mitos, indicam domínios sobre a natureza, ainda mais se pensarmos na natureza do ser que se reproduz e "deve” ser purificado desse ato via ritual científico cristão. Essa postura se distancia de outros atos de fé, como os autos

\footnotetext{
${ }^{50}$ Cluster: "grupo de notas adjacentes que soam simultaneamente" (SADIE, 1994: 204). Na partitura musical, aparenta um cacho (cluster) de notas, daí a procedência do nome em notações musicais.

${ }^{51}$ Parte da Passacaglia BWV 582 é apresentada no primeiro tema em forma de improviso - ver anexo II.
} 
religiosos, que celebram a dominação da natureza (HORKHEIMER; ADORNO, 1985: 204). Na cena do Batismo, o ritual de mortes leva-nos à lembrança da força inequívoca da natureza, o destino certo de todos os seres vivos, desenvolvendo a tese de que as ações de Michael são “a única solução” para a manutenção de sua família, ou ainda, a solução de domínio da natureza.

Ainda sobre certa significação induzida, a edição em cortes descrevendo aumentações parece ser composta por um primeiro percurso sem cortes aliado a rupturas de também larga duração, em comparação com as rupturas do final do percurso analisado. Percebemos uma construção em repetições que força a relação entre sintagmas, tornando a leitura coerente mesmo com as separações de continuidade: observamos o tempo de exposição e repetições de fragmentos. Ao que parece, o primeiro fragmento, com quarenta e três segundos, mostra-se como uma apresentação de um tema, ou algo que pretende ser representado como um antecedente fílmico/musical. A reapresentação desse tema, assim como a reapresentação contínua de descontínuos em aceleração, poderá ser compreendida como uma reapresentação do mesmo tema, questão essa também ligada ao estilo e seu reconhecimento pela repetição de elementos caracterizadores. O final do percurso mostra um resgate ao tema, de localização, tonalidade e harmonia, que indicam a enunciação do discurso conduzido por uma forma. Logo, a cena compõe, assim como a forma sonata musical, a descrição de um estilo, retórico, e midiaticamente expoente de significados construídos. A nosso ver, uma cena fílmico/musical pode alcançar a ênfase requerida pelo enunciador através das relações entre sintagmas, além das repetições de seus elementos. Percebemos a persuasão como resultante da ordem dessas repetições: apresentação, fixação, reapresentação, variação do tema, entre outras formas, além da rede de relações. Eficiente em muitos meios, parece-nos ter se desenvolvido pari-passu junto às necessidades de atenção dos meios. O processo de evolução técnica e conceitual, de mudança na escuta e o desenvolvimento dos meios de comunicação de massa, onde o cinema se moderniza, lapidaram a eficiência e a variação dessa forma relacional e persuasiva. Quando Barthes descreve a construção da boa fotografia como sendo semelhante a uma forma sonata (2012: 33), demonstra como muitas composições desenvolvem-se sobre a forma da repetição relacional objetivando a atenção e memória de seus públicos. A consagração da forma sonata em composições do período Romântico é um exemplo da necessidade de tornar o discurso, dessa vez musical, 
eficiente. No cinema, a forma sonata é constantemente alterada, acompanhando a especialização do espectador que compreende as repetições, tanto de elementos na narrativa como de estilos entre narrativas. A reprodutibilidade no cinema depende da observação desses espectadores quando compõe repetições relacionais na narrativa (BENJAMIN, 2011: 278): “Ao que parece, a quantidade tornou-se qualidade” (idem: 277).

Estamos próximos de uma comparação, a que liga a composição fílmico/musical de nosso exemplo com alguns conceitos composicionais de Richard Wagner. Com alguma distância da ópera tradicional italiana, Wagner altera a ideia de composição musical e composição cênica separadas, deixando para trás a ideia de uma cena de visualização da música, e propõe uma ênfase da intensão poética através da música (DEATHRIDGE; DAHLHAUS, 1988: 100). O espectador não está mais solto, livre para penetrar, através da ação visível, na essência oculta, revelada na música (ibidem) e alheio de si. Este espectador agora é considerado como um extemporâneo (NIETZSCHE, 2009: 40) que, embora alheio ao lugar, ou a pátria idealizada de Wagner, deve ter sua atenção resgatada. A construção mítica das composições de Wagner é justificada pela necessidade da transmissão de elementos textuais, poéticos e principalmente ideológicos interagidos com a música. Essa obra-de-arte-total ${ }^{52}$ coincide com a mudança social na Europa do século XIX, promovendo a necessidade de se comunicar com seu público: aqui observamos a mudança no conceito de música de palco, bem mais próximo da predicação da cena. Assim, como na ópera de Wagner, a cena do Batismo descreve a preocupação de uma enunciação musical ordenadora, que objetiva a apreensão do espectador extemporâneo. Podemos marcar uma diferença evidente entre estes dois momentos da música de palco que, em análise, exercem funções distantes. A ópera tradicional, aquela anterior a ruptura de Wagner, desenvolveu uma composição musical descritiva, ao passo que a nova obra total tenta desenvolver uma música persuasiva. Essa oposição pode ser comparada a certa linguagem descritiva, diferente de uma linguagem retórica. A subversão da língua pela ação retórica, a troca consciente objetivando a eficiência, parece equiparar-se à predicação musical no filme. Assim como as composições de Wagner, a cena do Batismo tenta atingir a máxima percepção do espectador, aliando ritmo, profundidade, expressões e cumulações regidas pelo contínuo musical persuasivo.

\footnotetext{
${ }^{52}$ Gesamtkusntwerk
} 
A Semiótica Tensiva de Zilberberg parece se estabilizar quando aponta a necessidade de eficiência argumentativa pelo discurso. Ela propõe uma retórica da divulgação (2007: 14-5), uma não-oposição que concede leituras em graus de extensidade entre o concentrado e o difuso, diferente da retórica veridictória implicativa. Na visão do autor, a possibilidade de eficiência de um discurso está centrada em seu potencial de propagação. A implicação que a comprovação da verdade exige em uma análise, com resultados definitivos entre verdade, mentira, segredo e falsidade, parece não caber no processo concessivo da eficiência do discurso: daí ter seu termo ligado à divulgação, a não divulgação é implicativa. A análise deixa, desta forma, de ter um ponto de vista único, mas se sustenta em um meio referencial, uma observação da estrutura, analisando desde o tempo/espaço até os sujeitos e suas ações da narrativa. Aqui, o traço pertinente será o difuso e átono, diferente das análises dos sobrevires, e prevendo uma continuidade da atonicidade. A manutenção da divulgação parece ser o elemento da retórica, e é onde Zilberberg encontra a elasticidade da cadeia de termos sobrecontrários e subcontrários. Assim, a Semiótica Tensiva se apoia na variabilidade das ações e na ótica sobre os intervalos buscando, de um lado, a retórica implicada que reconhece termos existentes e, de outro, a retórica explicada reconhecendo figuras compostas e relacionais: uma serve de referência para a outra compondo pontos de vista (ZILBERBERG, 2011: 203). Os intervalos mostram mais do que continuidades ou rupturas de continuidade. Eles apresentam graduações de movimentos internos expondo acelerações, retardos, ímpetos ou estagnações, ou seja, indicações de maior ou menor expectativa assim como suas resoluções. Aqui, tanto Zilberberg quanto Meyer ou Schaeffer combinam na questão sobre a composição e condução dos afetos de uma narrativa e suas autorreferências. A estrutura da qual a narrativa é composta depende da formação dos pontos de vista, suas importâncias hierárquicas e seus usos, levando confirmações e não veridicções, ao processo composicional.

Ao descrevermos a condição da predicação na Semiótica Tensiva entendemos melhor a música do cinema, sua utilização e seus efeitos de sentido. Desde que sem a visualização dos executores da música no filme, a composição predicadora está em condições de pureza, explicada pela acusmática e sua intersubjetividade diante do ser. Passamos ao entendimento reduzido da composição em um super campo: uma percepção expandida pela audição em expectativa. Somamos a esta pureza 
proporcionada pela acusmática as relações entre conotações fílmico/musicais, suas identidades e diferenças relacionadas às adjunções e supressões mostrando figuras retóricas. O produto dessa operação é a construção do discurso argumentativo via estratégias de expectativas: bem desenvolvido por Meyer e seu sistema culturalmente condicionado de expectativas. Somos levados à observação do texto fílmico/musical em três níveis: o isotópico, o predicativo e o retórico. Eles farão a análise dos percursos avaliando quantidades e qualidades de elementos e relações, deixando expostas as referências passionais e localizadoras do discurso. Parece-nos pertinente avaliar, após a análise da cena do Batismo e das conclusões dela descritas, que a ação da música predicadora vem ao auxílio da necessidade persuasiva, não apenas do meio de comunicação de massa, mas dos discursos que envolvam músicas. Adiante, podemos imaginar as possibilidades de utilização da análise predicadora ao observar ações musicais, isoladas dos discursos fílmicos, ou o contrário, fílmicas e isoladas de composições musicais, ou ainda, de observações sobre a prosódia falada, o discurso em performance, ou de outras formas de discurso em percurso que objetivem a atenção, memória e persuasão de um público. 
Conclusão 


\section{Conclusão}

A proposta de utilização das bases da Semiótica Tensiva, principalmente a estabilizada por Claude Zilberberg, para o reconhecimento de elementos analíticos em um discurso fílmico/musical, pareceu-nos apropriada pois esta teoria contempla a preocupação com uma estrutura retórica organizadora na narrativa. Para Zilberberg, a eficiência do discurso depende da organização hierarquizada dos estilos, produzindo o chamado traço animado aristotélico. Na composição musical, aqui regente dos sentidos fílmicos, os estilos terão papéis importantes no que chamamos de uma conduta de formação de sentidos, em vista de sua necessidade dentro de um sistema e de seu reconhecimento diante de enunciatários também reconhecedores do mesmo sistema.

Em análise, parece-nos provável eleger o estilo como fator preponderante nas escolhas narrativas promotoras de uma retórica: o dispositio. A retórica compõe, juntamente com a língua e o mito, um sistema culturalmente controlado do qual possibilita-nos a observação dos meios de comunicação de massa, assim como da música predicadora de sentidos no cinema. A predicação aqui argumentada pareceu-nos eficaz ao provar sua articulação na análise da Semiótica Tensiva quando observado o ato de recção. A música regente dos sentidos visuais exerce predicação necessária para a construção do logos, o pequeno drama frasal. Em outra representação da mesma construção, para que exista uma frase, um drama ou uma narrativa, necessitamos da observação de um relacionamento hierárquico em que regentes exerçam ações sobre os regidos: sem a predicação não se configura um discurso. Com isso, a predicação exposta pela música no cinema provou a existência de um texto único, promovendo a leitura desse texto em auxílio analítico aos outros textos existentes na mesma esfera de sentidos: a soma dos textos gera sincretismo e é percebidos pelo espectador de forma única graças à predicação. Teremos então a visão dos demais elementos da Semiótica Tensiva, como o ritmo, a profundidade, as isotopias marcadas pelas conotações e as possíveis leituras de paradigmas e cadeias de termos. Todos os elementos dessa teoria provaram sua utilização na análise na cena do Batismo do filme O Poderoso Chefão de Francis Ford Coppola, de 1972.

Mesmo com o conhecimento dos elementos de Semiótica Tensiva, consideramos importante a descoberta do uso ordenado da expectativa como efeito retórico. A expectativa como elementos da narrativa pode ser argumentada através da fusão das teorias, de Zilberberg, de Shaeffer e de Meyer, além dos argumentos aliados de outras 
bases. As teorias aqui envolvidas mostraram também uma escolha por certa linha estrutural científica, rica ao pensamento zilberberguiano, e de grande utilização no reconhecimento das possibilidades da análise. Na cena analisada o meio de comunicação cinema foi observado pela retórica musical, exemplificando uma máxima expectativa construída por cumulações. A hipérbole ali desenvolvida só pode atingir seu ápice passional pela ação da música que desenvolve expectativas controladas. Mesmo aplicando parte da Teoria Tensiva no exemplo escolhido, pudemos demonstrar as possibilidades de análise e de reconhecimento de elementos fílmicos/musicais. Outro exemplo, em um novo esforço teórico, poderá abordar maiores resultados alinhados à Semiótica Tensiva de Zilberberg.

Concluímos com a análise que o cinema tende à reconstrução das auras no que se dirige ao pressuposto passional do meio. As paixões das apresentações públicas anteriores à reprodutibilidade técnica mantinham uma coerente qualidade, aura, só possível de ser percebida pela vivência do fenômeno. A reprodutibilidade técnica modificou a disposição dessa expressão, deixando as qualidades alteradas, se não destruídas pela composição dos fantasmas sensoriais. A música, através da predicação, tenta reconstruir a qualidade do meio, embora de ação variável pela estabilidade dos estilos, promovendo estados patêmicos aos sencientes destinatários que expectam. A aura perdida é reordenada pela predicação, aliada aos efeitos retóricos e geradores de timias. Assim, oscilam-se os contínuos, rítmico pela espera e pela repetição, até a perda da sensação temporal. Nesse momento, a música “reeduca” o consciente do espectador para manipulá-lo.

Pela análise, passamos ao entendimento de quais acontecimentos farão o estilo e como ele será reordenado relacionando-se com outros até as construções de sentidos. Percebemos em nossa divisão cronométrica a aparição de um padrão aliado aos acontecimentos e exercícios da cena. A comparação nos levou ao fundamento de uma forma sonata. Ela pode ser uma condição das narrativas que pretendem criar expectativas. Sabemos que, na história da música, essa forma condiciona a auto referência do espectador, e agora expectador, até a certeza de sua satisfação: uma aplicação de sentidos retóricos destinados ao público. Seja pela composição sobre antecedentes e consequentes, ou pela criação de códigos, como os leitmotiv(s) wagnerianos, aliados aos estilos, a forma sonata se apresentou na composição da cena do batismo induzindo o expectador até a satisfação do final. 
A descoberta de uma variação não descrita por Zilberberg em sua Semiótica Tensiva trouxe a possibilidade de novas abordagens sobre o acontecimento. Na cena do Batismo, o percurso que desenvolve a hipérbole aponta para um termo tônico da cadeia, porém este se apresenta fragmentado ${ }^{53}$. A movimentação da ação até o termo [fortíssimo] ocorre por certo empilhamento de elementos, ação de cumulação e geradora da sensação do êxtase da cena. No entanto, concluímos que se trata de uma tonicidade pela fragmentação, disposição essa diferente das exemplificadas pelo autor da Teoria Tensiva.

Consideramos, portanto, como profícua a possibilidade de uma análise através das lentes zilberberguianas da Semiótica Tensiva. Sua aplicação gerou bons conhecimentos sobre o texto analisado e gerou leituras sobre a qualidade do objeto. Resta-nos agora o desenvolvimento de exemplos mais amplos de análise fílmico/musical.

\footnotetext{
${ }^{53}$ Descrito na página 125.
} 
Referências Bibliográficas

\section{Bibliografia Citada:}

ADORNO, Theodor W.; EISLER, Hanns. El cine y la música. Madri: Fundamentos, 1981. - $2^{\circ}$ ed. Título original: Komposition für den Film.

ADORNO, Thodor; HORKHEIMER, Max. Dialética do esclarecimento. Rio do Janeiro: Zahar, 1985.

AUMONT, Jacques; MARIE, Michel. Dicionário teórico e crítico de cinema. Campinas, Papirus, 2012, $5^{\circ}$ ed.

BAUDELAIRE, Charles. As flores do mal, Rio de Janeiro: Nova Fronteira, 2015.

BARTHES, Roland. A câmara clara: nota sobre a fotografia. Rio de Janeiro: Nova Fronteira, 2012.

Mitologias. Rio de Janeiro: Difel, 2009.

2001. A antiga retórica. In: A aventura semiológica. São Paulo: Martins Fontes,

BAZIN, André. O que é o cinema? São Paulo: Cosac Naify, 2014.

BENJAMIN, Walter. A obra de arte na época de sua reprodutibilidade técnica. In: LIMA, Luiz Costa. Teoria da cultura de massa. São Paulo: Paz e Terra, 2011.

BENT, Ian; DRABKIN, William. Analysis: The new Grove Handbooks in music. Londres: Macmillan, 1998.

BENVENISTE, Émile. Problemas de linguística geral I. Campinas: Pontes, 2005a. Problemas de linguística geral II. Campinas: Pontes, 2005b.

CARRASCO, Ney. Sygkhronos: a formação da poética mausical do cinema. São Paulo: Via Lettera, 2003.

CHION, Michel. Un art sonore, le cinéma: histoire, esthétique, poétique. Paris: Cahiers du cinema, 2003.

A audiovisão: som e imagem no cinema. Lisboa: Texto \& Grafia, 2011.

COPPOLA, Francis Ford. The Godfather Notebook. Nova York: Regan Arts, 2016.

DAVIS, Richard, Complete guide to film scoring: the art and business of writing music for movies and tv. Boston: Berklee Press, 2010. 
DEATHRIDGE. John; DAHLHAUS. Carl. Wagner. São Paulo: L\&PM, 1988.

DELORME, Stéphane. Francis Ford Coppola. Paris: Cahiers du cinema Sarl, 2010. Coleção Master of cinema. Ed. Em inglês.

DOURADO, Henrique Autran. Dicionário de termos e expressões da música. São Paulo: 34, 2008.

DUARTE. Rodrigo. Adorno/Horkheimer \& a dialética do esclarecimento. Rio de Janeiro: Zahar, 2004.

DURAND, Jacques. Retórica e imagem publicitária. In: METZ, Christian. et al. A análise das imagens. Tradução de Luis Costa Lima e Priscila Viana de Siqueira. Petrópolis: Vozes, 1974.

EISENSTEIN, Sergei. A forma do filme. Rio de Janeiro: Zahar, 2002.

FIELD, Syd. Manual do roteiro: os fundamentos do texto cinematográfico. Rio de Janeiro: Objetiva, 2001.

FIORIN, José Luiz. Argumentação. São Paulo: Contexto, 2015.

FLOCH, Jean Marie. Semiotica marketing e comunicazione: Dietro i segni, le strategie.Milão, FrancoAngeli: 1992.

A contribuição da semiótica estrutural para o design de um hipermercado.

Galaxia, São Paulo (online) n 27, p. 21-47, junho de 2014 -

http://dx.doi.org/10.1590/1982-25542014119610

FONTANILLE, Jacques; ZILBERBERG, Claude. Tensão e significação. Tradução de Ivã Carlos Lopes, Luiz Tatit e Waldir Beividas. São Paulo: Humanitas, 2001.

Semiótica do Discurso. São Paulo: Contexto, 2012.

GANCE, Abel. Le temps de l'image est venu! In: L’Art Cinématographique. V. II, 1927, pp. 83-107.

GREIMAS, Algirdas J.; COURTÉS, Joseph. Dicionário de semiótica. Tradução de Alceu Dias Lima et al. São Paulo: Cultrix, 1979.

GREIMAS, Algirdas J. Elementos para uma Teoria da Interpretação da Narrativa Mítica. In: BARTHES, Roland. et al. Análise estrutural da narrativa. Petrópolis: Vozes, 1972.

GROUT, Donald Jay; PALISCA, Claude. História da Música Ocidental. Lisboa: Gradiva, 2011. 5 Ed.

HJELMSLEV, Louis. Prolegômenos a uma teoria da linguagem. São Paulo: Perspectiva, 2009.

JAKOBSON, Roman. Linguística e comunicação. São Paulo: Cultrix, 2011. 
LÉVI-STRAUSS. A origem dos modos à mesa. São Paulo: Cosac Naify, 2006.

O cru e o cozido. São Paulo: Cosac Naify, 2010.

MARIE, Micheal. Cinema e linguagem. In: Aumont, Jacques. Et al. A estética do filme. Campinas: Papirus, 2012.

MÁXIMO, João. A música do cinema: os 100 primeiros anos. Rio de Janeiro: Rocco, 2003a -Vol: I.

Vol: II.

A música do cinema: os 100 primeiros anos. Rio de Janeiro: Rocco, 2003b -

MENEZES, Flo. Música eletroacústica: história e estética. São Paulo: EdUSP, 2009.

METZ, Christian. A significação do cinema. São Paulo: Perspectiva, 1972.

O significante imaginário: psicanálise e cinema. Lisboa: Horizonte, 1980.

MEYER, Leonard B. Music, the arts of ideas. Chicago: Univ. of Chicago, 1970.

Explaining music: essay and explorations. Berkeley, Los Angeles, Londres:

University of California Press, 1973.

MOLES, Abraham. Sociodinâmica da cultura; tradução: Mauro W. Barbosa de Almeida. São Paulo: Perspectiva, 1974.

NEVES, Maria Helena de Moura. A gramática: história, teoria e análise, ensino. São Paulo: UNESP, 2002.

NIETZSCHE, Friedich. Wagner em Bayreuth. São Paulo: Zahar, 2009.

PUZO, Mario. O poderoso chefão. Rio de Janeiro: Bestbolso, 2015. $11^{\circ}$ ed.

ROSENFELD, Anatol. Cinema: arte \& indústria. São Paulo: Perspectiva, 2013.

SADIE, Stanley. (Ed.) Dicionário Grove de Música: Edição concisa. Rio de Janeiro: Jorge Zahar, 1994.

SCHAEFFER, Pierre. Tratado de los objetos musicales. Madri: Alianza, 2003.

Ensaios sobre o rádio e o cinema: estética e técnica das artes-relé. Belo Horizonte: UFMG, 2010.

SCHOENBERG, Arnold. Fundamentos da composição musical. São Paulo: EDUSP, 2015. $3^{\circ}$ ed.

SCIANNAMEO, Franco. Nino Rota's The Godfather trilogy: a film score guide. Maryland: Scarecrow, 2010. (livro eletrônico Kindle)

STRAVINSKI, Igor; CRAFT, Robert. Conversas com Igor Stravinski. São Paulo: Perspectiva, 2010. 
TATIT, Luiz. Semiótica à luz de Guimarães Rosa. São Paulo: Ateliê, 2010.

TRUFFAUT, François; SCOTT, Helen. Hitchcock/Truffaut: entrevistas, edição definitiva. Tradução de Rosa Freire d’Aguiar. São Paulo: Companhia da Letras, 2004.

VEGLIA, Luciano. Nino Rota tra musica e cinema. Matera, It.: La stamperia Liantonio, 2014. (livro eletrônico Kindle)

ZILBERBERG, Claude. Plaidoyer pour le tempo. In: FONTENILLE, Jacques. Le devenir. Limoges, Pulim, 1995.

Rythme et générativité. Études Littéraires, vol. 29, n. 1, 1996, p. 21-38. Précis de grammaire tensive. Tangence, n. 70, automne, 2002, p. 111-143.

As condições semióticas da mestiçagem, Tradução de Ivã Carlos Lopes e Luiz Tatit. In: CAÑIZAL, Eduardo Peñuela; CAETANO, Kati Eliana (orgs). O olhar à deriva: mídia significação e cultura. São Paulo: Annablume, 2004.

. Razão e poética do sentido. Tradução de Ivã Carlos Lopes, Luiz Tatit e Waldir Beividas. São Paulo: Ed. Universidade de São Paulo, 2006. Louvado o acontecimento. Revista Galáxia, São Paulo, n. 13, 2007, p. 13-28. 2010, p. 1-13. Observação sobre a base tensiva do ritmo. Estudos Semióticos, vol. 6, n. 2, . Elementos de semiótica tensiva. Tradução de Ivã Carlos Lopes, Luiz Tatit e Waldir Beividas. São Paulo: Ateliê, 2011(a).

.Des formes de vie aux valeurs. Paris: PUF, 2011(b).

La structure tensive: suivi de notes sur la structure des paradigmes et sur la dualité de la poétique. Liège: Presses Universitaires de Liège, 2012.

Note sur la portée du tempo. Actes Sémiotiques. N. 118, 2015, p. 1-8.

ZINNA, Alessandro. L’andamento ritmico di Seven. Ocula. Bologna, V. 9, p. 2008. (http://www.ocula.it/rivista.php?id=19)

WOLF, Mauro. Teorias das comunicações de massa. São Paulo: Martins Fontes, 2008. 
Filmes:

O PODEROSO Chefão. Direção: Francis Ford Coppola. Produção: Albert S. Ruddy. Los Angeles, Estados Unidos: American Zoetrope, 1972. Sonoro, colorido, película cinematográfica (2h 55min). Roteiro: Mario Puzo e Francis Ford Coppola. Trilha Sonora: Nino Rota. Interpretes principais: Marlon Brando, Al Pacino, James Caan, Robert Duval, Diane Keaton, John Cazale, Talia Shire, et al. (Título original: "The Godfather")

THE GODFATHER Supplements. Direção: Robert A. Harris. Los Angeles, Estados Unidos: American Zoetrope, 2008. Sonoro, colorido, suporte digital (1h 20min). Interpretes principais: Matin Cohen, Francis Ford Coppola, Allen Daviau, et al. (Título Original: "Emulsional Rescue: Revealing 'The Godfather””)

NINO ROTA, Entre o cinema e o erudito. Direção: Vassili Sillovic. Produção: José Montes-Baquer e Dietrich Von Watzdorf. Editor: Lorcan Page. 1993. Sonoro, colorido, película cinematográfica, suporte em DVD (48 min). Interpretes principais: Suso Cecchi D’Amico, Pier Marco di Santi, Federico Felini, et al. Roteiro: Pit Riethmüller. (Título original: Zwischen Kino und Konzert - Der Komponist Nino Rota)

A GREVE. Direção: Sergei M. Eisenstein. Produção: Boris Mikhin. St. Petersburg, Russia: Goskino; Proletkult. 1925. Mudo, preto-e-branco, película cinematográfica. (1h 22min). Roteiro: Grigori Aleksandrov e Sergei M. Eisenstein. Interpretes principais: Maksim Shtraukh, Grigori Aleksandrov, Mikhail Gomorov, Ivan Ivanov, Ivan Klyukvin, et al. (Título original: "Stachka”).

PSICOSE. Direção e Produção: Alfred Hitchcock. Nova Iorque, Estados Unidos: Shamley Productions, 1960. Sonoro, preto-e-branco, película cinematográfica (1h 49 min). Roteiro: Joseph Stefano e Robert Bloch. Trilha Sonora: Bernard Herrmann. Interpretes principais: Anthony Perkins, Vera Miles, John Gavin, Janet Leigh, Martin Balsam, et al. (Título osiginal: "Psycho”)

\section{Bibliografia suplementar:}

Semiótica:

BARTHES, Roland. et al. Análise estrutural da narrativa. Petrópolis: Vozes, 1972.

O óbvio e o obtuso: ensaios críticos III; tradução de Léa Novaes. Rio de Janeiro: Nova Fronteira, 1990.

Elementos de semiologia. Tradução de Izidoro Blikstein. São Paulo: Cultrix, 2012. 19 ed.

BARROS, Diana Luz Pessoa. Teoria semiótica do texto. São Paulo: Ática, 1990.

BEIVIDAS, Waldir. Inconsciente e sentido: psicanálise, linguística e semiótica. São Paulo: Annablume, 2009. 
Inconsciente et verbum: psicanálise, semiótica, ciência, estrutura. São Paulo: Humanitas/FFLCH, 2000.

2015.

Semiótica sincrética: posições (a língua no cinema). São Paulo: Annablume,

BERTRAND, Denis. Caminhos da semiótica literária. Bauru: EDUSC, 2003.

BLIKSTEIN, Izidoro. Kaspar Hauser ou a fabricação da realidade. São Paulo: Cultrix, 2003.

CAETANO, Kati E. (orgs) Olhar à deriva: mídia significação e cultura. Tradução: Ivã Carlos Lopes e Luiz Tatit. São Paulo: Annablume, 2004.

DINIZ, Maria Lúcia V. P.; PORTELA, Jean Cristtus (orgs). Semiótica e Mídia: textos, práticas, estratégias. Bauru: UNESP/FAAC, 2008.

ECO, Umberto. Tratado geral de semiótica. São Paulo: Perspectiva, 2002.

FIORIN. José Luiz. Elementos de Análise do Discurso. São Paulo: Contexto, 2011.

. Para uma definição das linguagens sincréticas. In: OLIVEIRA, Ana Claudia de; TEIXEIRA, Lucia. Linguagens na Comunicação: desenvolvimentos de semiótica sincrética. São Paulo: Estação das letras e cores, 2009. pp.15-40.

FLOCH, Jean-Marie. Petites mythologies de l'oeil et de l'esprit: pour une sémiotique plastique. Paris, Amsterdan: Hadés-Benjamins, 1985.

FONTANILLE, Jacques; LOMBARDO, Patrizia; RALLO DITCHE, Elisabeth. Dictionnaire des passions littéraires. Paris: Belin, 2005.

GREIMAS, Algirdas Julien; FONTANILLE, Jacques. Semiótica das Paixões. São Paulo: Ática, 1993.

HJELMSLEV, Louis. Ensaios Linguísticos. São Paulo: Perspectiva, 1991. LOPES, Edward. A identidade e a diferença: raízes históricas das teorias estruturais da narrativa. São Paulo: Edusp, 1997.

Fundamentos da linguística contemporânea. São Paulo: Cultrix, 1980.

LOPES, Ivã Carlos; TATIT, Luiz. Elos de melodia e letra: análise semiótica de seis canções. Cotia, SP: Ateliê, 2008.

OLIVEIRA, Ana Claudia de; TEIXEIRA, Lucia. Linguagens na Comunicação:

desenvolvimentos de semiótica sincrética. São Paulo: Estação das letras e cores, 2009.

PIETROFORTE, Antonio Vicente. A significação musical: um estudo semiótico da música instrumental erudita. São Paulo: Annablume, 2015.

SAUSSURE, Ferdinand de. Escritos de Linguística Geral. Tradução de Carlos Augusto Leuba Salum e Ana Lúcia Franco. São Paulo: Cultrix, 2012. 
SAUSSURE, Ferdinand de. Curso de Linguística Geral. Organizado por Charles Bally e Albert Sechehaye. São Paulo: Cultrix, 2012.

TATIT, Luiz. Musicando a semiótica. São Paulo: Annablume, 2008.

TODOROV, Tzvetan. As estruturas narrativas. São Paulo: Perspectiva, 2013. Introdução à literatura fantástica. São Paulo: Perspectiva, 2012.

Cinema

AUMONT, Jacques; MARIE, Michel. A análise do filme. Lisboa: Texto \& Grafia, 2011.

BELLOUR, Raymond. L’Analyse du film. Paris: Albatros, 1979.

GARDIES, René. Compreender o cinema e as imagens. Lisboa: Texto \& Grafia, 2011

IVÁNOV, Viatcheslav V. Dos diários de Serguei Eisenstein e outros ensaios. São Paulo: EDUSP, 2009.

JAKOBSON, Roman. Linguística. poética. Cinema. São Paulo: Perspectiva, 2011.

JOLY, Martune. Le charme discret de la répétition. In: Revue Vertigo. "Rhétorique de cinema”. Paris, 1991. ISSN: 0985-1402.

LOTMAN, Yuri. Estética e semiótica do cinema. Lisboa: Estampa, 1978.

MANZANO, Luiz A. F. Som-Imagem no cinema: a experiência alemã de Fritz Lang. São Paulo: Perspectiva, 2010.

MARTIN, Marcel. A linguagem cinematográfica. São Paulo: Brasiliense, 2013.

MATOS, Eugênio. A arte de compor música para o cinema. Brasília: Senac, 2014.

PARENT-ALTIER, Dominique. O argumento cinematográfico. Lisboa: Texto \& Grafia, 2011.

VANOYE, Francis; GOLIOT-LÉTÉ, Anne. Ensaio sobre a análise fílmica. CampinasSP: Papirus, 2012.

Música

ADORNO, Theodor W. Filosofia da nova música. São Paulo: Perspectiva, 2009.

ATTALI, Jacques. Bruits: Essai sur l'economie politique de la musique. Paris: Fayard/Puf, 2001. 
AUDISSINO, Emilio. John Williams's film music. Madison: University of Wisconsin Press, 2014.

BOSSEUR, Jean-Yves. Musique et beaux-arts: de l'antiquité au XIXe siècle. Paris: Minerve, 1999.

BOULEZ, Pierre. A música hoje. São Paulo: Perspectiva, 2005.

CARMO, José R. Da voz aos instrumentos musicais: um estudo semiótico. São Paulo: Annablume, 2005.

CHION, Michel. Músicas, media e tecnologias. Lisboa: Ed. Instituto Piaget, 1997.

GRIFFITHS, Paul. A música moderna: uma história concisa e ilustrada de Debussy a Boulez. Rio de Janeiro: Zahar, 2011.

LIGGERI, Domenico. Musica per i nostri occhi: storie e segreti dei videoclipe. Milão: Tascabili Bompiani, 2007.

MOLINO, Jeaqn. Fait musical et sémiologie de la musique. In: Musique em jeu. Paris: Éditions du Seuil, n 17, p. 37-62, 1975 a. 1975b. Fait musical et sémiologie de la musique. Musique em jeu. Paris, n 17, p. 37-62,

NATTIEZ, Jean-Jacques. O combate entre Cronos e Orfeu: ensaios de semiologia musical aplicada. São Paulo: Via Lettera, 2005.

Music and Discourse: toward a semiology of music. New Jersey: Princeton University Press, 1990.

. Musicologie générale et semiology. Paris: Christian Bourgois Ed., 1987.

1975.

ROSEN, Charles. A geração Romântica. São Paulo: Edusp, 1995.

RUWET, Nicolas. Langage, musique, poésie. Paris: Éditions du Seuil, 1972. 11-36, 1975. Théorie et methods dans les etudes musicales. Musique em jeu. Paris, $n^{\circ} 17, p$.

SCHIFRIN, Lalo. Music composition for film and television. Boston: Berklee Press, 2011.

SCOENBERG, Arnold. Funções estruturais da harmonia. Traduçãi de Eduardo Seincman. São Paulo: Via Lettera, 2004.

Harmonia. Tradução de Marden Maluf. São Paulo: UNESP, 2001. 
SEINCMAN, Eduardo. Estética da comunicação musical. São Paulo: Via Lettera, 2008.

TARASTI, Eero. Myth and music: s semiotic approach to the Aesthetics of myth in music, especially that of Wagner, Sibelius and Stravinsky. Nova York: Mouton, 1979.

Le rôle du temps dans le discours musical. In: ARRIVÉ, Michel; COQUET, Jean-Claude (orgs). Sémiotique en jeu: a partir et autour de l'oeuvre d'A. J.

Greimas. Paris-Amsterdam: Hadès-Benjamins, 1987.

TRAGTENBERG, Lívio. Música de cena. São Paulo: Perspectiva, 2008.

VALLE, Andrea. La notazione musicale contemporânea: aspetti semiotici ed estetici. Torino: EDT, 2002.

WILLIAMS, Kent. Theories and analyses of twentieth-century music. Philadelphia: Harcourt Brace, 1997.

Outras referências

ADORNO, Theodor W. Introdução à sociologia da música: doze preleções teóricas. São Paulo: UNESP, 2011. 2002. $3^{\circ}$ edição.

Indústria Cultural e Sociedade.São Paulo: Paz e Terra,

A televisão e os padrões da cultura de massa. In: ROSENBERG, Bernard e WHITE, David Manning. Cultura de Massa. São Paulo: Cultrix, 1973.

CARRASCO, Ney. Sygkhronos: a formação da poética mausical do cinema. São Paulo: Via Lettera, 2003.

MERLEAU-PONTY. Maurice. A prosa do mundo. São Paulo: Cosac \& Naify, 20012.

O olho e o Espírito. São Paulo: Cosac \& Naify, 2004.

PROPP, Vladimir. Morfologia do conto maravilhoso. Rio de Janeiro: ForenseUniversitária, 1984. 
Anexo I:

Na montagem do filme, o texto original do batismo em latim foi alterado. Não em seu conteúdo, mas na ordem de suas aparições. As razões não são claras, mas podemos intuir a necessidade do diretor de edição em compor uma atmosfera propícia pertencente ao filme.

O que se apresenta abaixo é o texto completo do batismo e sua referência em inglês, original do filme e da fonte da qual esse texto foi retirado. Os números mostram a ordem das falas na cena.

\author{
The Rite of Baptism \\ Part I \\ Outside the Church
}

The priest (wearing a violet stole), sponsors, and the catechumen stand in the narthex of the church, symbolizing that at this point, the candidate is not a member of the Church.

The Questioning

Priest: N., what do you ask of the Church of God?

Priest: N., quid petis ab Ecclesia Dei?

Sponsor/Catechumen: Faith.

Sponsor/Catechumen: Fidem.

Priest: What does Faith offer you?

Priest: Fides, quid tibi præstat?

Sponsor/Catechumen: Life everlasting.

Sponsor/Catechumen: Vitam æternam.

Priest: If then you desire to enter into life, keep the

commandments. 'Thou shalt love the Lord thy God with thy Priest: Si igitur vis ad vitam ingredi, serva mandata. Diligis whole heart and with thy whole soul and with thy whole

Dominum Deum tuum ex toto corde tuo, et ex tota anima mind; and thy neighbour as thyself.' tua, et ex tota mente tua, et proximum tuum sicut teipsum.

The Exsufflation

The priest then breathes 3 times on the candidate in the form of a Cross, recalling the Spirit (breath, wind, "ruach") of God.

Priest: Go forth from him (her), unclean spirit, and give

Priest: Exi ab eo (ea), immunde spiritus, et da locum Spiritui Sancto Paraclito.

place to the Holy Spirit, the Paraclete.

\title{
The Sign of the Cross
}

The priest now makes the Sign of the Cross with his thumb on the candidate's forehead and breast.

Priest: Receive the Sign of the Cross both upon your

forehead + and also upon your heart +; take to you the faith Priest: Accipe signum Crucis tam in fronte, quam in corde, of the heavenly precepts; and so order your life as to be, from henceforth, the temple of God. sume fidem cælestium præceptorum: et talis esto moribus, ut templum Dei iam esse possis.

Priest: Let us pray: Mercifully hear our prayers, we beseech Priest: Oremus: Preces nostras, quaesumus, Domine, Thee, O Lord; and by Thy perpetual assistance keep this Thine elect, N, signed with the sign of the Lord's cross, so that, preserving this first experience of the greatness of Thy glory, he (she) may deserve, by keeping Thy commandments, to attain to the glory of regeneration. Through Christ our Lord. Sponsor/Catechumen: Amen. clementer exaudi; et hunc electum tuum (hanc electam tuam), N. crucis Dominicae impressione signatum (-am), perpetua virtute custodi; ut magnitudinis gloriae tuae rudimenta servans, per custodiam mandatorum, ad regenerationis gloriam pervenire mereatur (-antur). Per Christum Dominum nostrum.

Sponsor/Catechumen: Amen.

The Imposition of Hands

The priest places his hands on the candidate's head.

Priest: Let us pray: Almighty, everlasting God, Father of our Lord Jesus Christ, look graciously down upon this Thy servant, N., whom Thou hast graciously called unto the beginnings of the faith; drive out from him (her) all blindness of heart; break all the toils of Satan wherewith he
Priest: Oremus: Omnipotens sempiterne Deus, Pater Domini nostri lesu Christi, respice dignare super hunc famulum tuum (hanc famulam tuam), N, quem (quam) ad rudimenta fidei vocare dignatus es: omnem caecitatem cordi ab eo (ea) expelle: disrumpe omnes laqueos Satanae, quibus fuerat (- 
(she) was held: open unto him (her), O Lord, the gate of Thy loving kindness, that, being impressed with the sign of Thy wisdom, he (she) may be free from the foulness of all wicked desires, and in the sweet odor of Thy precepts may joyfully serve Thee in Thy Church, and grow in grace from day to day. Through the same Christ our Lord. Amen.

Priest: Through the same Christ our Lord.

Sponsor/Catechumen: Amen ant) colligatus (-a); aperi ei, Domine ianuam pietatis tuae imbutus (-a), omnium cupiditatum foetoribus careat (-ant), et ad suavem odorem praeceptorum tuorum laetus tibi in Ecclesia tua deserviat, et proficiat de die in diem Per eundem Christum Dominum nostrum. Amen.

\section{Priest: Per eundum Christum Dominum nostrum.}

Sponsor/Catechumen: Amen

The Imposition of Salt

Now the priest puts a little blessed in the candidate's mouth. Salt is the symbol of that wisdom which gives a relish for the sweetness of divine nourishment; preserves, by the teaching of the Gospel, from the corruption of sin, and prevents evil passions from growing in men's souls. Adult catechumens might be signed on the brow, ears, eyes, nostrils, mouth, breast, and between the shoulders before the imposition of salt. If this procedure is followed, afterwards the candidate will kneel, recite the Our Father several times, and a Cross is made on his forehead, first by the sponsor and then by the priest.

Priest: N., Receive the salt of wisdom; let it be to thee a token of mercy unto everlasting life. May it make your way easy to eternal life.

Sponsor/Catechumen: Amen.

Priest: Peace be with you.

Sponsor/Catechumen: And with your spirit.

Priest: Let us pray: O God of our fathers, O God the Author of all truth, vouchsafe, we humbly beseech Thee, to look graciously down upon this Thy servant, N., and as he (she) tastes this first nutriment of salt, suffer him (her) no longer to hunger for want of heavenly food, to the end that he (she) may be always fervent in spirit, rejoicing in hope, always serving Thy name. Lead him (her), O Lord, we beseech Thee, to the laver of the new regeneration, that, together with Thy faithful, he may deserve to attain the everlasting rewards of Thy promises. Through Christ our Lord.

Priest: Through the same Christ our Lord. Sponsor/Catechumen: Amen

Priest: N., accipe sal sapientiæ: propitiatio sit tibi in vitam æternam.

Sponsor/Catechumen: Amen.

Priest: Pax tecum.

Sponsor/Catechumen: Et cum spiritu tuo.

Priest: Oremus: Deus patrum nostrorum, Deus universae conditor veritatis, te supplices exoramus, ut hunc famulum tuum (hanc famulam tuam) respicere digneris propitius, et hoc primum pabulum salis gustantem, non diutius esurire permittas, quo minus cibo expleatur caelesti, quatenus sit semper spiritu fervens, spe gaudens, tuo semper nomini serviens. Perduc eum (eam), Domine, quaesumus ad novae regenerationis lavacrum, ut cum fidelibus tuis promissionum tuarum aeterna praemia consequi mereatur. Per Christum Dominum nostrum.

Priest: Per eundum Christum Dominum nostrum. Sponsor/Catechumen: Amen

Part II:

Admission into the Church Building

\section{The Exorcism}

The priest makes the Sign of the Cross over the candidate three times and says:

Priest: I exorcise thee, unclean spirit, in the name of the Father + and of the Son, + and of the Holy + Spirit, that thou goest out and depart from this servant of God, N. For He commands Thee, accursed one, Who walked upon the sea, and stretched out His right hand to Peter about to sink. Therefore, accursed devil, acknowledge thy sentence, and give honor to the living and true God: give honor to Jesus Christ His Son, and to the Holy Spirit; and depart from this servant of God, N. because God and our Lord Jesus Christ hath vouchsafed to call him (her) to His holy grace and benediction and to the font of Baptism.
Priest: Exorcizo te, immunde spiritus, in nomine Patris + et Filii + et Spiritus + Sancti, ut exeas, et recedas ab hoc famulo (hac famula) Dei N.: ipse enim tibi imperat, maledicte damnate, qui pedibus super mare ambulavit, et Petro mergenti dexteram porrexit. Ergo, maledicte diabole, recognosce sententiam tuam, et da honorem Deo vivo et vero, da honorem lesu Christo Filio eius, et Spiritui Sancto, et recede ab hoc famulo (hac famula) Dei N, quia istum (am) sibi Deus et Dominus noster lesus Christus ad suam sanctam gratiam, et benedictionem, fontemque Baptismatis vocare dignatus est.

The Sign of the Cross

The priest again makes the Sign of the Cross on the candidate's forehead

Priest: And this sign of the holy Cross, which we make upon his (her) forehead, do thou, accursed devil, never dare to violate.

Priest: Et hoc signum sanctae Crucis, + quod nos fronti eius damus, tu, maledicte diabole, numquam audeas violare. 
Priest: Through the same Christ our Lord. Sponsor/Catechumen: Amen
Priest: Per eundum Christum Dominum nostrum.

Sponsor/Catechumen: Amen

The Imposition of Hands

For the final time, the priest lays his hand on the candidate's head

Priest: Let us pray: O Holy Lord, Father Almighty, Eternal God, Author of light and truth, I implore Thine everlasting and most just goodness upon this Thy servant N., that Thou wouldst vouchsafe to enlighten him (her) with the light of Thy wisdom: cleanse him (her) and sanctify him (her), give unto him (her) true knowledge; that, being made worthy of the grace of Thy Baptism, he (she) may hold firm hope, right counsel and holy doctrine.

Priest:Through Christ our Lord.

Sponsor/Catechumen: Amen.
Priest: Oremus: Aeternam, ac iustissimam pietatem tuam deprecor, Domine, sancte Pater omnipotens, aeterne Deus, auctor luminis et veritatis, super hunc famulum tuum (hanc famulam tuam) $\mathrm{N}$, ut digneris eum (eam) illuminare lumine intelligentiae tuae: munda eum (eam), et sanctifica: da ei scientiam veram, ut, dignus (-a) gratia Baptismi tui effectus $(-a)$, teneat (-ant) firmam spem, consilium rectum, doctrinam sanctam.

Priest: Per Christum Dominum nostrum.

Sponsor/Catechumen: Amen.

Admission into the Church Building

The priest lays the end of his stole on the candidate as a symbol of his priestly authority, and admits him into the church building, which is the symbol of the Church of Christ. If the catechumen is an adult and was annointed in Part I above, he may be asked to lie prostrate before the Altar in adoration of Christ before this next step.

Priest: N., enter thou into the temple of God, that thou mayest have part with Christ unto life everlasting.

Sponsor/Catechumen: Amen.
Priest: N., ingredere in templum Dei, ut habeas (-ant) partem cum Christo in vitam aeternam.

Sponsor/Catechumen: Amen.

\section{The Credo and Pater}

Sponsor/Catechumen: I believe in God the Father Almighty, Sponsor/Catechumen: Credo in Deum, Patrem Creator of heaven and earth, and in Jesus Christ his only Son omnipotentem, Creatorem cæli et terræ. Et in lesum our Lord, who was conceived by the Holy Ghost, born of the Christum, Filium eius unicum, Dominum nostrum: qui Virgin Mary; suffered under Pontius Pilate, was crucified, dead, and buried. He descended into Hell. On the third day, He rose again from the dead. He ascended into heaven, and sitteth at the right hand of God the Father Almighty; from thence shall He come to judge the living and the dead. I believe in the Holy Ghost, the holy Catholic Church; the communion of saints; the forgiveness of sins; the resurrection of the body, and life everlasting. Amen. conceptus est de Spiritu Sancto, natus ex Maria Virgine, passus sub Pontio Pilato, crucifixus, mortuus, et sepultus: descendit ad inferos; tertia die resurrexit a mortuis; ascendit ad cælos; sedet ad dexteram Dei Patris omnipotentis; inde venturus est iudicare vivos et mortuos. Credo in Spiritum Sanctum, sanctam Ecclesiam catholicam, Sanctorum communionem, remissionem peccatorum, carnis resurrectionem, vitam æternam. Amen.

Sponsor/Catechumen: Our Father, who art in heaven, Sponsor/Catechumen: Pater noster, qui es in cælis, hallowed be thy name. Thy kingdom come. Thy will be done sanctificetur nomen tuum. Adveniat regnum tuum. Fiat on earth as it is in heaven. Give us this day our daily bread. And forgive us our trespasses, as we forgive them that trespass against us. And lead us not into temptation: but deliver us from evil. Amen.

voluntas tua, sicut in cælo, et in terra. Panem nostrum cotidianum da nobis hodie. Et dimitte nobis debita nostra, sicut et nos dimittimus debitoribus nostris. Et ne nos inducas in tentationem: sed libera nos a malo. Amen.

In the Nave of the Church

\section{The Solemn Exorcism}

Priest: I exorcise thee, every unclean spirit, in the name of God the Father + Almighty, in the name of Jesus + Christ, His Priest: Exorcizo te, omnis spiritus immunde, in nomine Dei + Son, our Lord and Judge, and in the power of the Holy + Spirit, that thou be depart from this creature of God N, which our Lord hath deigned to call unto His holy temple, that it may be made the temple of the living God, and that the Holy Spirit may dwell therein. Through the same Christ our Lord, who shall come to judge the living and the dead, and the world by fire Patris omnipotentis, et in nomine lesu + Christi Filii eius, Domini et ludicis nostri, et in virtute Spiritus + Sancti, ut discedas ab hoc plasmate Dei N, quod Dominus noster ad templum sanctum suum vocare dignatus est, ut fiat templum Dei vivi, et Spiritus Sanctus habitet in eo. Per eundum Christum Dominum nostrum, qui venturus est iudicare vivos et mortuos, et saeculum per ignem.

\section{The Ephpheta}

The priest takes a little spittle and touches the ears and nostrils of the candidate with it. For health reasons, the use of spittle may be omitted. This rite comes from Mark 7:33-35, when Jesus healed the deaf-mute: "And taking him from the

multitude apart, he put his fingers into his ears: and spitting, he touched his tongue. And looking up to heaven, he groaned and said to him: Ephpheta, which is, Be thou opened. And immediately his ears were opened and the string of 
his tongue was loosed and he spoke right.".

Priest: Ephpheta, that is to say, Be opened, for an odour of Priest: Ephpheta, quod est, Adaperire. In odorem suavitatis. sweetness. Be thou, devil, begone; for the judgement of God shall draw near. Tu autem effugare, diabole; appropinquabit enim iudicium Dei.

The Renunciation of Satan

\section{Priest: N., do you renounce Satan?}

Sponsor/Catechumen: I do renounce him. Priest: And all of his works?

Sponsor/Catechumen: I do renounce him. Priest: And all his pomps?

Sponsor/Catechumen: I do renounce him.

Priest: N., abrenuntias Satanæ?

Sponsor/Catechumen: Abrenuntio.

Priest: Et omnibus operibus eius?

Sponsor/Catechumen: Abrenuntio.

Priest: Et omnibus pompis eius?

Sponsor/Catechumen: Abrenuntio.

The Annointing

The priest annoints the candidate with the oil of catechumens on the heart and between the shoulders in the form of a Cross, saying:

Priest: I annoint you + with the oil of salvation in Christ Jesus our Lord, that you may have everlasting life.

Priest: Ego te linio Oleo salutis in Christo lesu Domino nostro, ut habeas vitam æternam.

Sponsor/Catechumen: Amen.

Sponsor/Catechumen: Amen.

Part IV

At the Font

The priest removes his violet stole and puts on a white one.

The Profession of Faith

Priest: N., do you believe in God the Father Almighty, Creator of Heaven and Earth?

Priest: N., credis in Deum Patrem omnipotentem, creatorem cæli et terram?

Sponsor/Catechumen: I do believe.

Sponsor/Catechumen: Credo.

Priest: Do you believe in Jesus Christ, His only Son our Lord, Priest: Credis in lesum Christum, Filium eius unicum, Who was born and Who suffered?

Sponsor/Catechumen: I do believe.

Priest: Do you believe in the Holy Ghost, the Holy Catholic Church, the communion of Saints, the forgiveness of sins, the resurrection of the body and life everlasting?

Sponsor/Catechumen: I do believe. Dominum nostrum, natum, et passum?

Sponsor/Catechumen: Credo.

Priest: Credis et in Spiritum sanctum, sanctam Ecclesiam catholicam, Sanctorum communionem, remissionem peccatorum, carnis resurrectionem, et vitam æternam?

Sponsor/Catechumen: Credo.

\section{Baptism (Matter and Form of the Sacrament)}

If the one to be baptized is a baby, the godparents take him to the font (the godmother holds him in her arms, the godfather touches the baby's shoulder with his right hand); if he is an adult, the sponsor puts his right hand on the shoulder of the one to be baptized.

Priest: N., will you be baptized?

Priest: N., vis baptizari?

Sponsor/Catechumen: I will.

Sponsor/Catechumen: Volo.

The priest pours water over the head of the candidate three times, once after each mention of the Divine Persons. The he uses will have been consecrated during the Easter Vigil or on the Eve of the Pentecost. As he pours the water, the priest says these words (or the words of a conditional Baptism):

Priest: I baptize you in the name of the Father + and of the Son + and of the Holy + Spirit.

Priest: N, ego te baptizo in nomine + Patris, et Filii, +, et Spiritus + Sancti.

The Annointing with Chrism

Priest: May the Almighty God, the Father of our Lord Jesus Christ, Who hath regenerated thee by water and the Holy Spirit, and who hath given thee the remission of all thy sins, may He Himself + anoint thee with the Chrism of Salvation, in the same Christ Jesus our Lord, unto life eternal.

Sponsor/Catechumen: Amen.

Priest: Peace be with you.

Sponsor/Catechumen: And with your spirit.
Priest: Deus omnipotens, Pater Domini nostri lesu Christi, qui te regeneravit ex aqua et Spiritu Sancto, quique dedit tibi remissionem omnium peccatorum, ipse te + liniat Chrismate Salutis in eodem Christo lesu Domino nostro in vitam aeternam.

Sponsor/Catechumen: Amen.

Priest: Pax tibi.

Sponsor/Catechumen: Et cum spiritu tuo. 


\section{The White Linen Cloth}

This priest takes a white linen cloth - symbolizing the purity of a soul cleansed from all sin, and a relic of the days when the newly baptized wore white albs for 8 days - and places it on the head of the candidate.

Priest: Receive this white garment, which mayest thou carry Priest: Accipe vestem candidam, quam perferas without stain before the judgment seat of our Lord Jesus immaculatam ante tribunalem Domini nostri lesu Christi, ut Christ, that thou mayest have life everlasting. habeas vitam æternam. Amen.

The Lighted Candle

The priest gives the candidate or the sponsor a lighted candle.

Priest: Receive this burning light, and keep thy Baptism so Priest: Accipe lampadem ardentem, et irreprehensibilis as to be without blame: keep the commandments of God, custodi Baptismum tuum: serva Dei mandata ut cum that when the Lord shall come to the nuptials, thou mayest Dominus venerit ad nuptias, possis occurrere ei una cum meet Him together with all the Saints in the heavenly court, omnibus Sanctis in aula caelesti, habeasque vitam and mayest have eternal life and live for ever and ever. aeternam, et vivas in saecula saeculorum.

Last Words of Good Will 
Anexo II
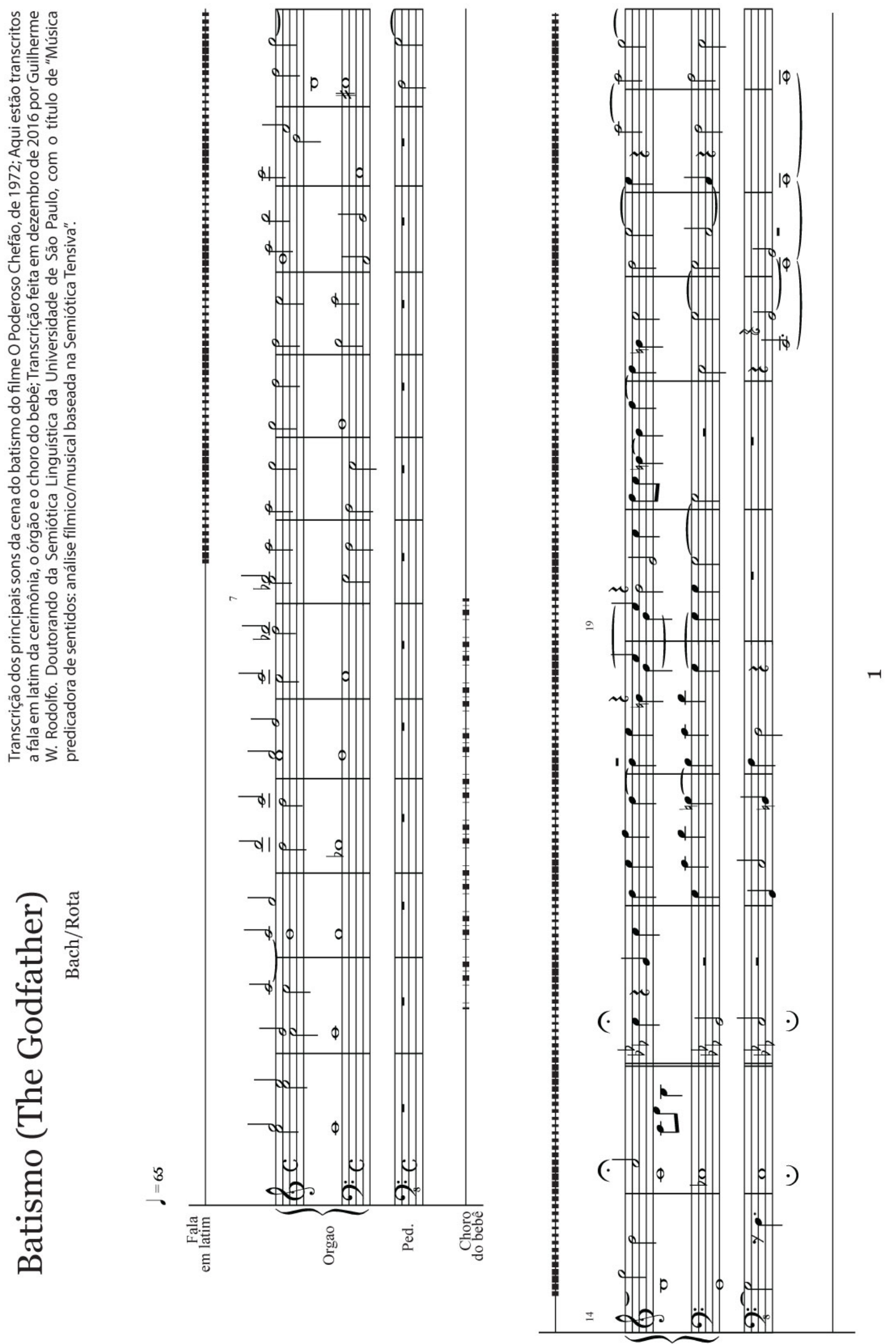

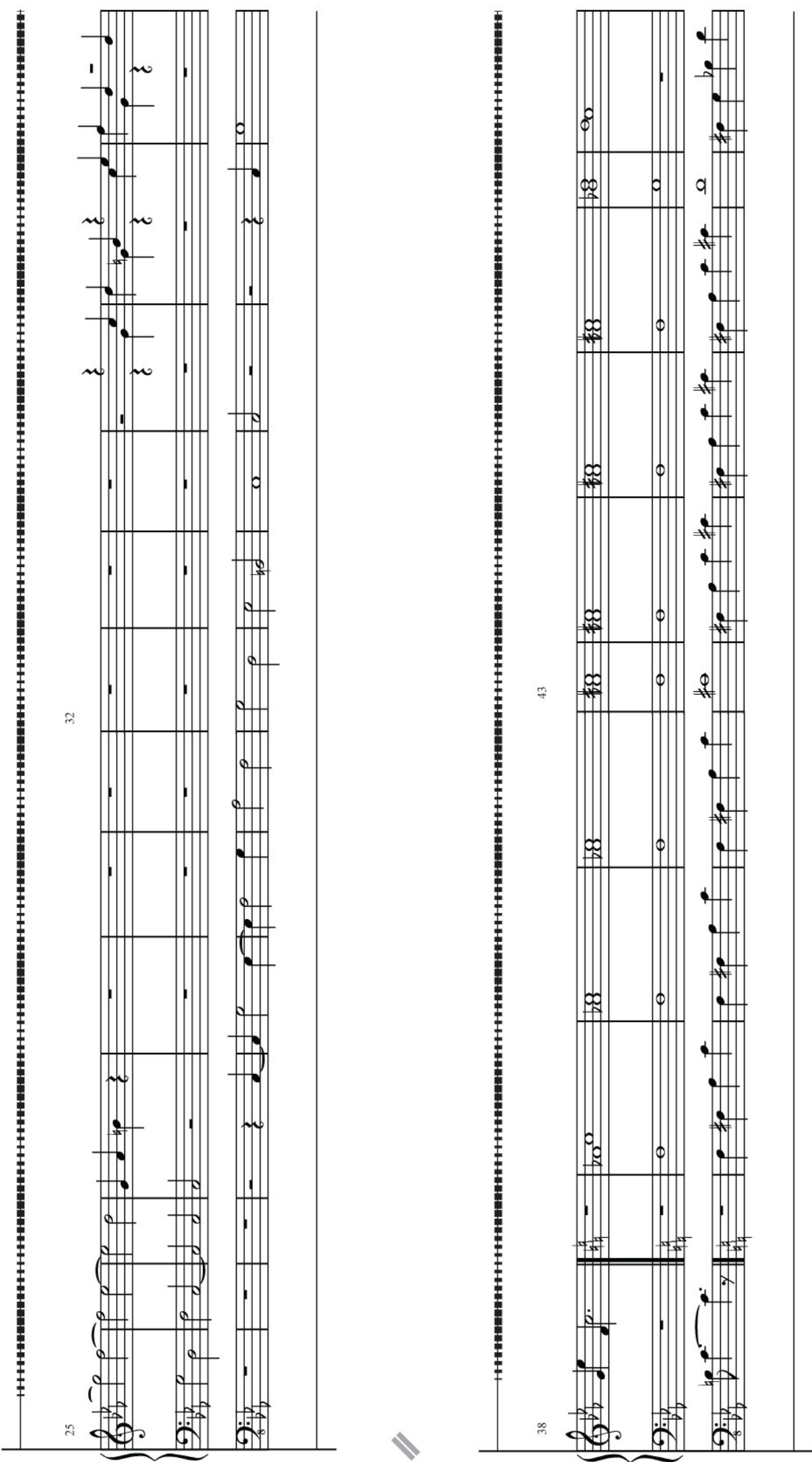

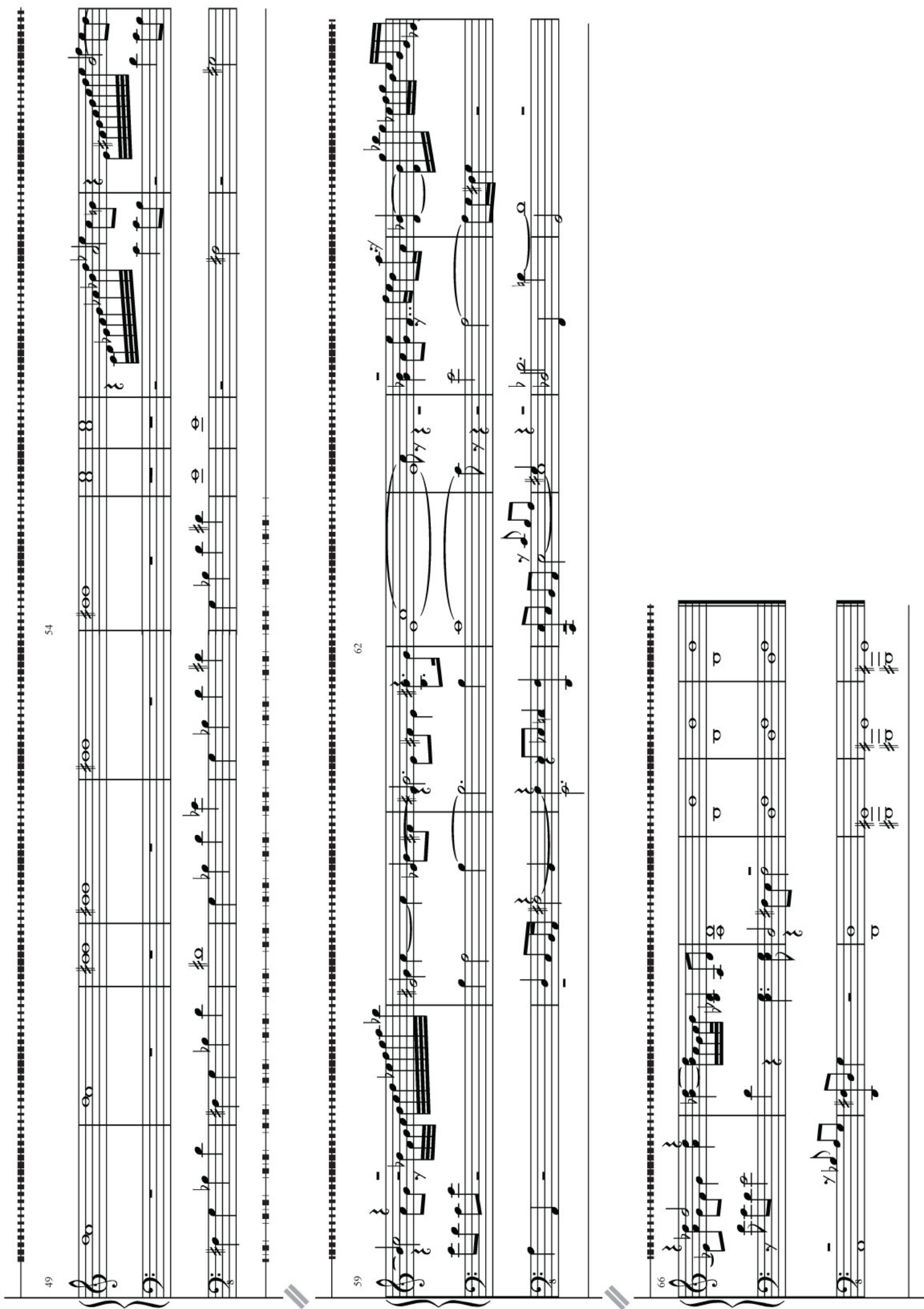
Anexo III

\section{Batismo (The Godfather)}

Transcrição Musical:

Bach/Rota

Guilherme Weffort Rodolfo

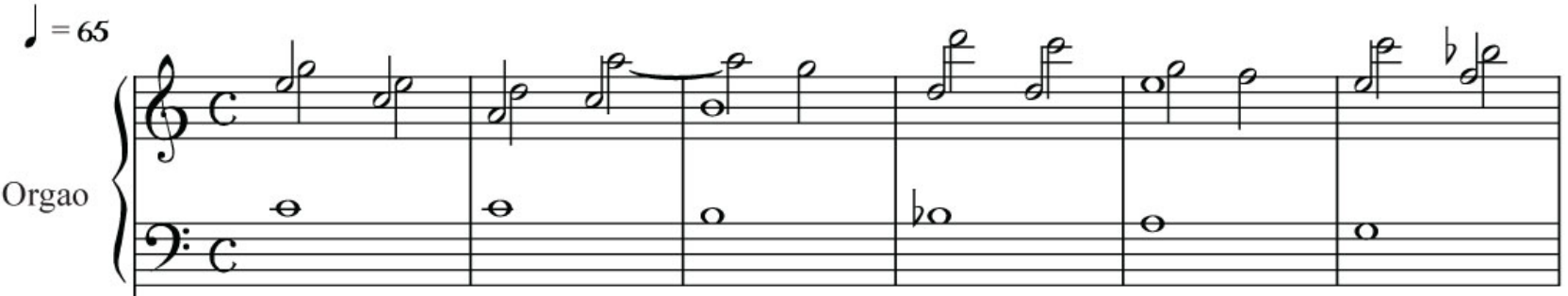

Ped.

$9^{\circ} \mathrm{C}$
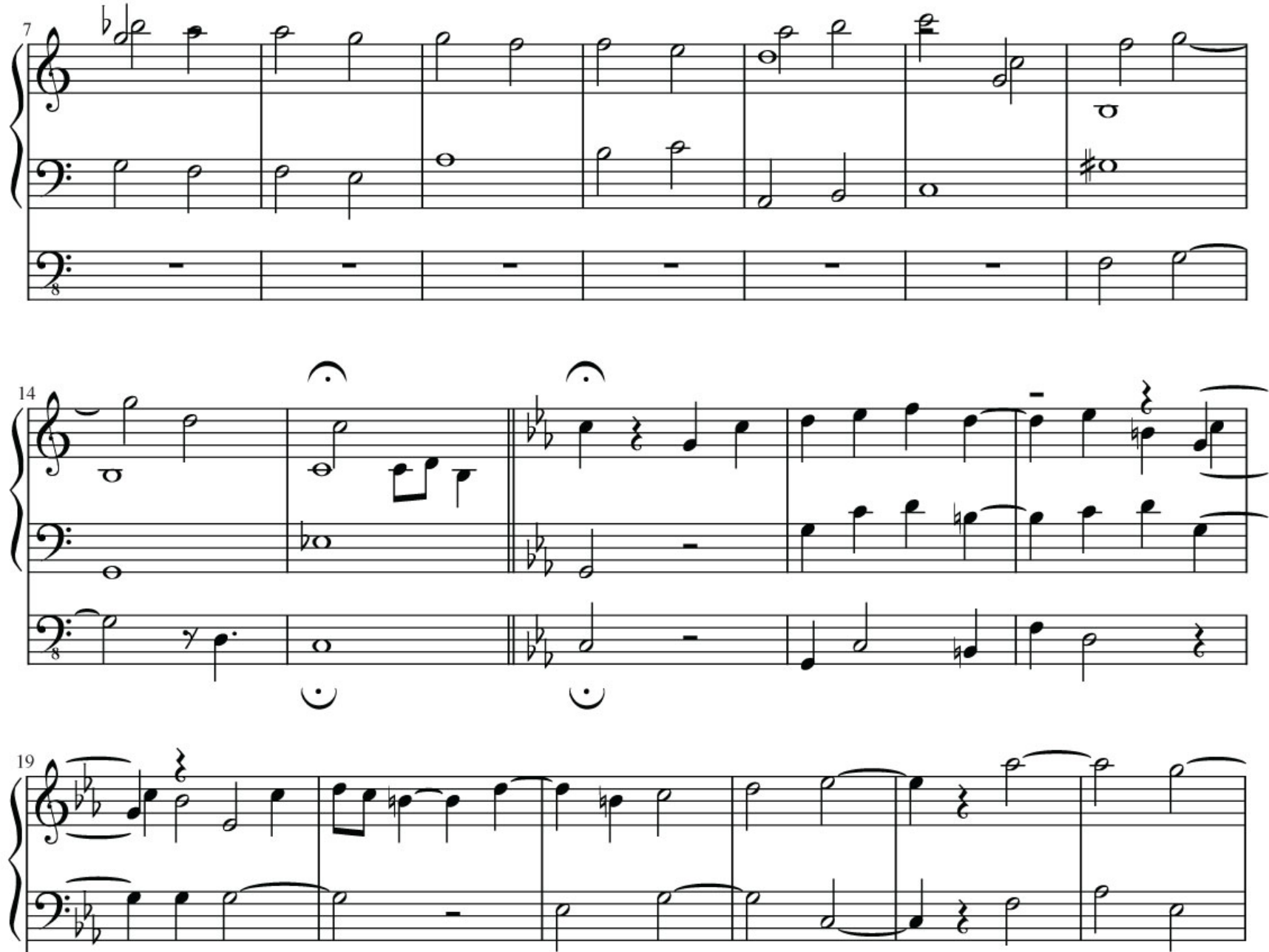

(2)

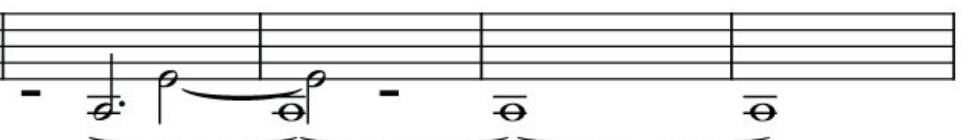



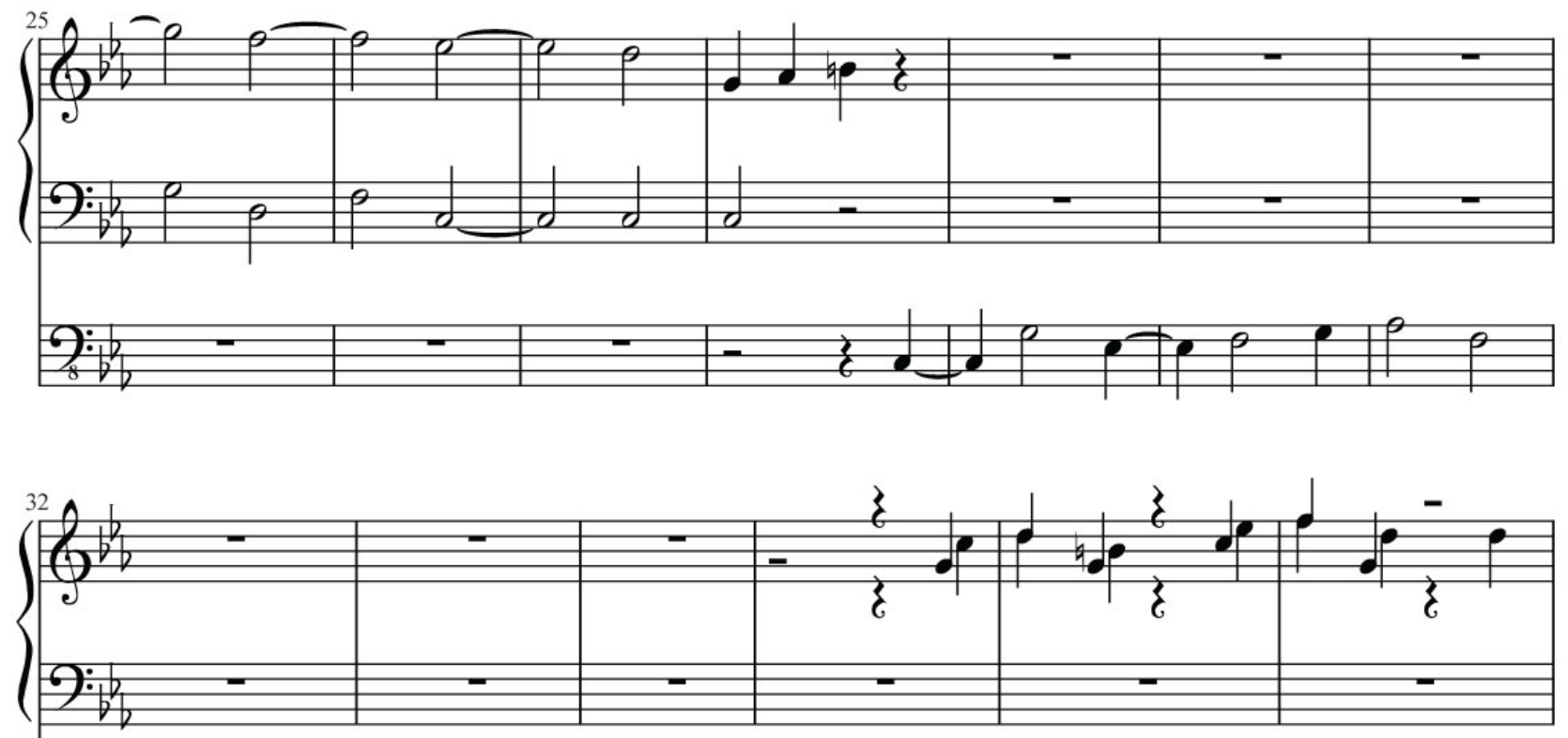

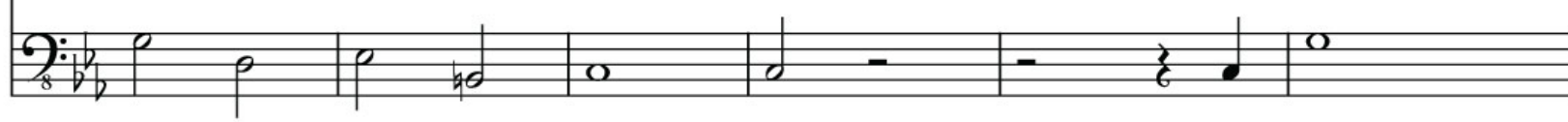
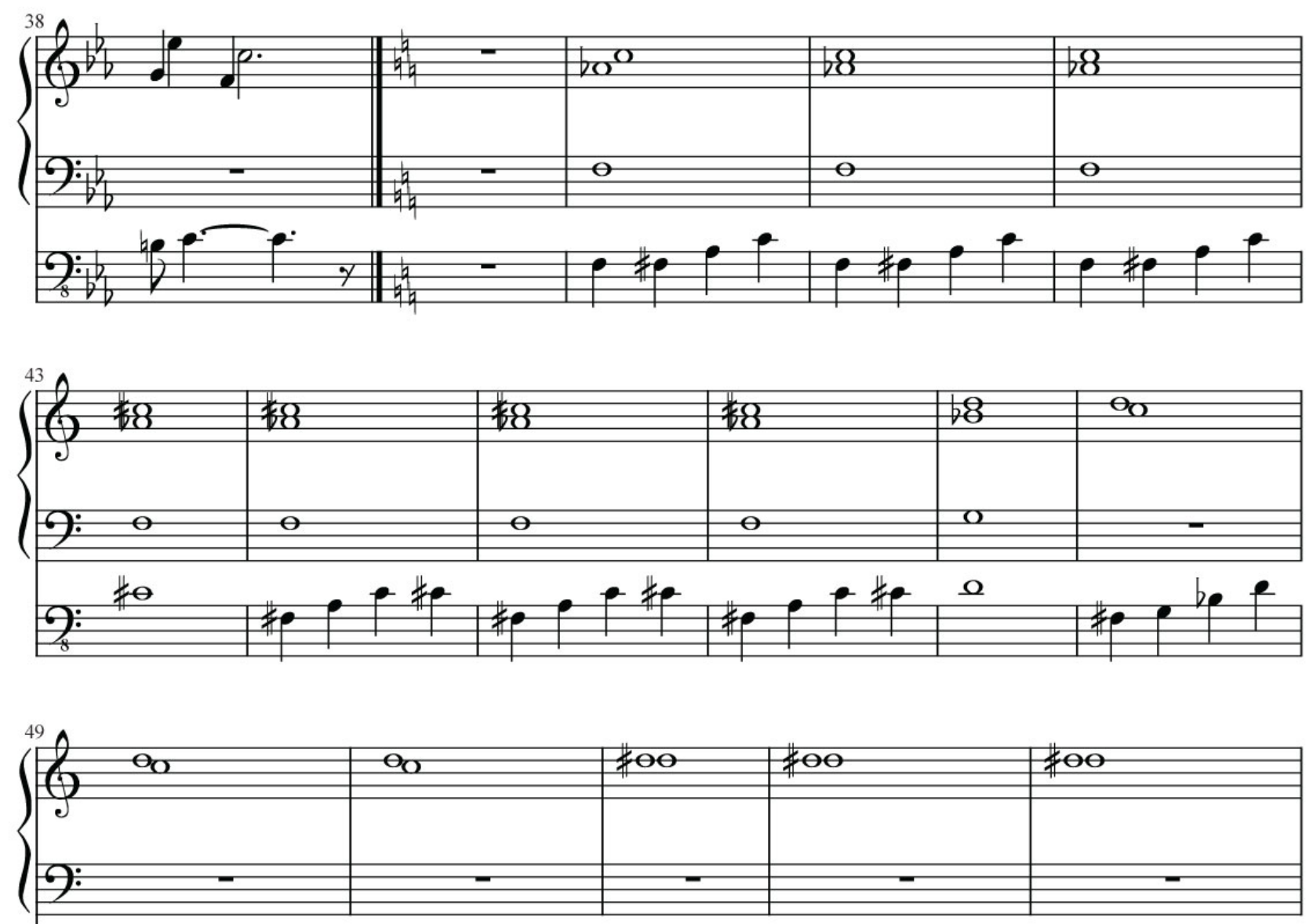

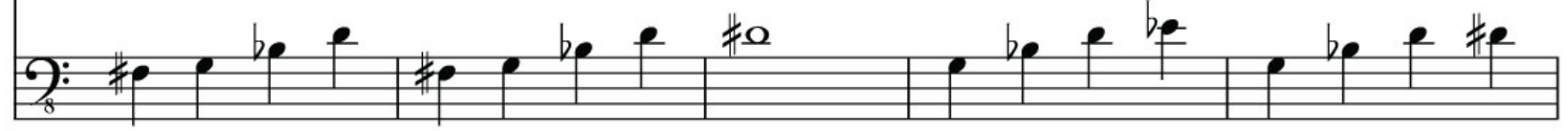




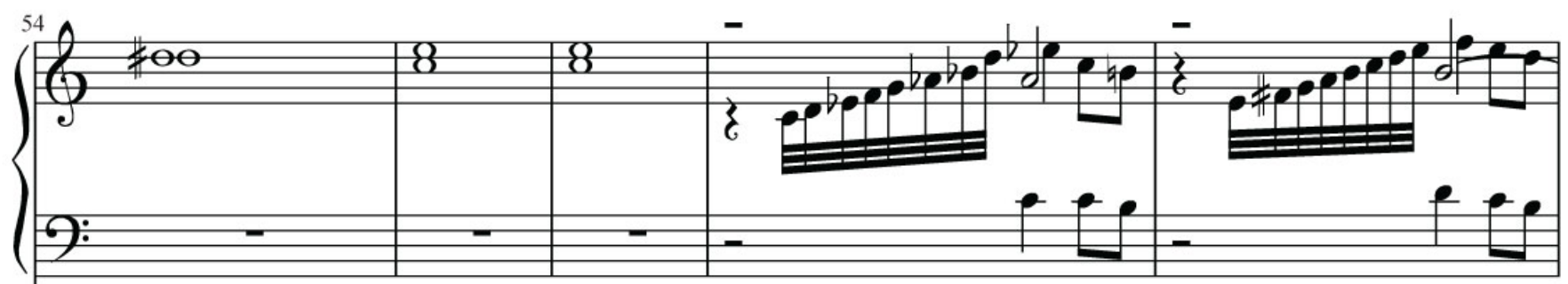

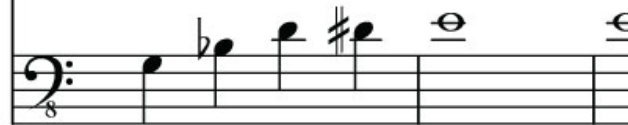

$\Theta$

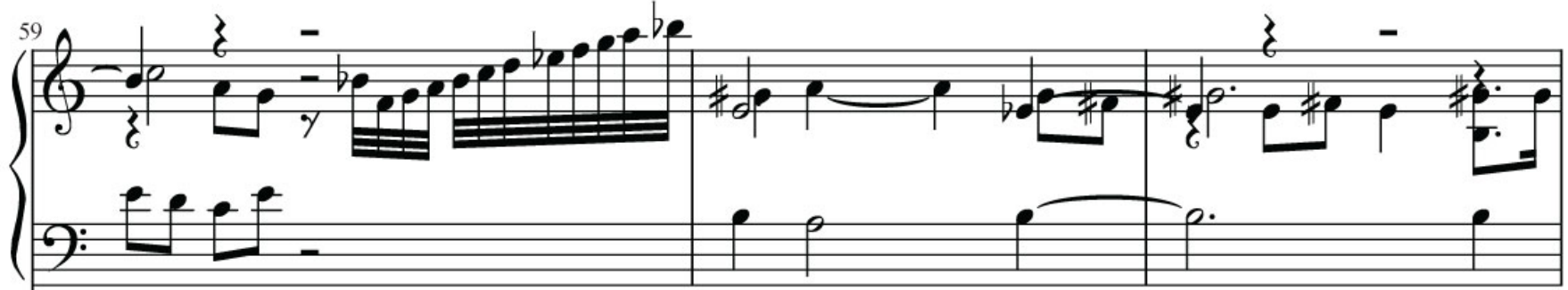

20!

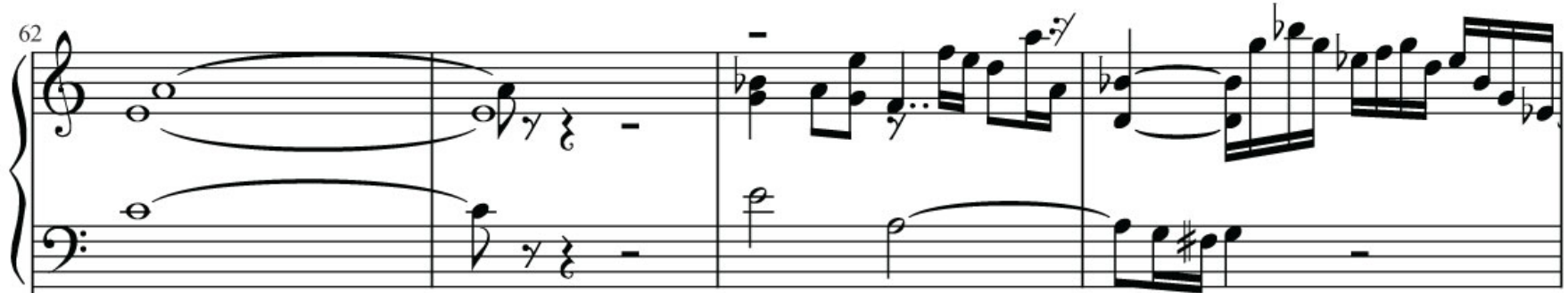

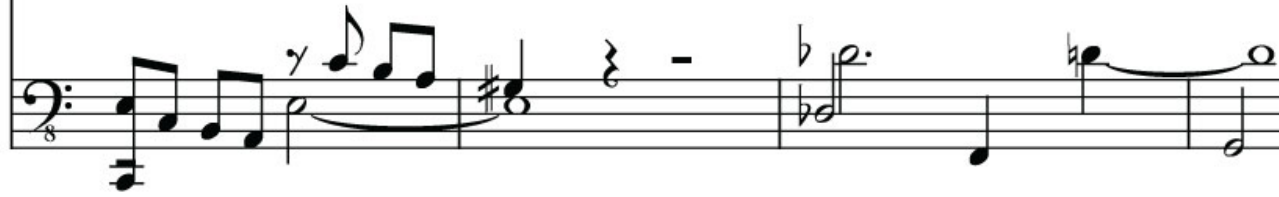

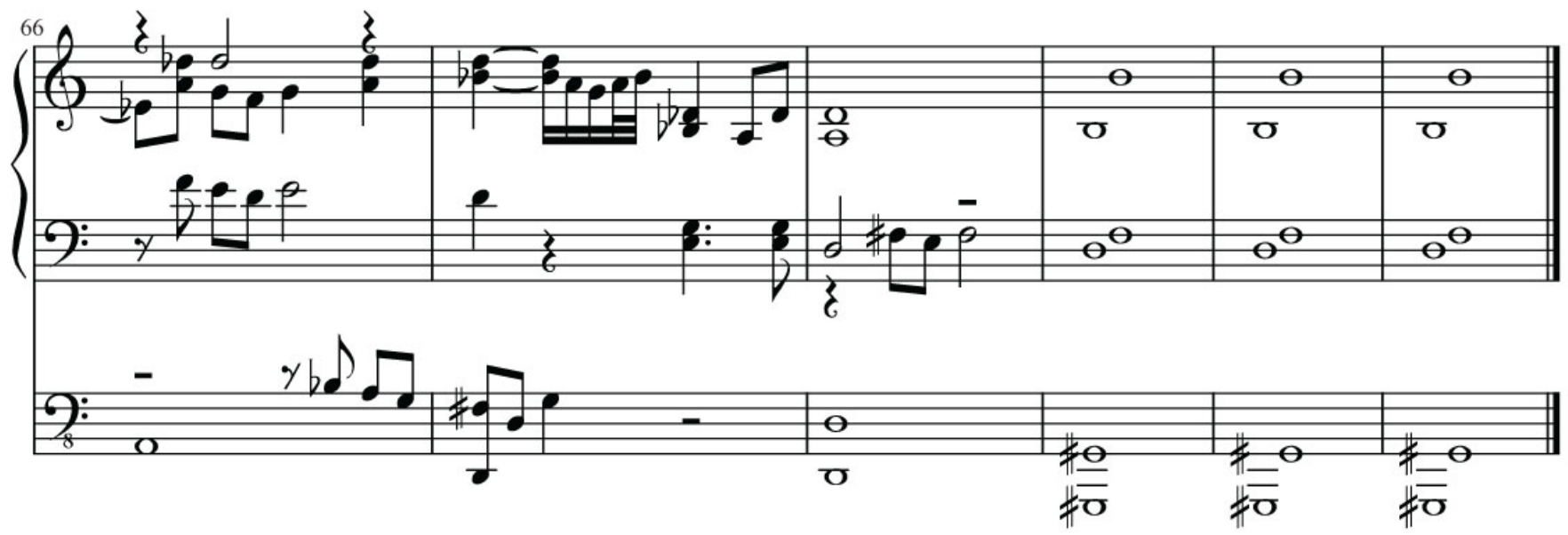

